\title{
An Analysis of the Risk of Transporting Spent Nuclear Fuel by Train
}

\author{
H. K. Elder
}

September 1981

Prepared for Sandia National Laboratories'

Transportation Technology Center for the United States Department of Energy under

Contract DE-AC06-76RLO 1830

Pacific Northwest Laboratory

Operated for the U.S. Department of Energy

by Battelle Memorial Institute 


\title{
NOTICE
}

This report was prepared as an account of work sponsored by the United States Government. Neither the United States nor the Department of Energy, nor any of their employees, nor any of their contractors, subcontractors. or their employees. makes any warranty. express or implied. or assumes any legal liability or responsibility for the accuracy. completeness or usefulness of any information, apparatus, product or process disclosed, or represents that its use would not infringe privately owned rights.

The views, opinions and conclusions contained in this report are those of the contractor and do not necessarily represent those of the United States Government or the United States Department of Energy.

\author{
PACIFIC NORTHWEST LABORATORY \\ operated by \\ BATTELLE \\ for the \\ UNITED STATES DEPARTMENT OF ENERGY \\ Under Contract DE-AC06-76RLO 1830
}

\author{
Printed in the United States of America \\ Available from \\ National Technical Information Service \\ United States Department of Commerce \\ 5285 Port Royal Road \\ Springfield. Virginia 22151
}

Price: Printed Copy s

$\therefore$ Microfiche $\$ 3.00$

NTIS

-Pages Selling Price

$\begin{array}{ll}001-025 & \$ 4.00 \\ 026-050 & \$ 4.50 \\ 051-075 & \$ 5.25 \\ 076-100 & \$ 6.00 \\ 101-125 & \$ 6.50 \\ 126-150 & \$ 7.25 \\ 151-175 & \$ 8.00 \\ 176-200 & \$ 9.00 \\ 201-225 & \$ 9.25 \\ 226-250 & \$ 9.50 \\ 251-275 & \$ 10.75 \\ 276-300 & \$ 11.00\end{array}$




\section{7}

\section{AN ANALYSIS OF THE RISK \\ OF TRANSPORTING SPENT \\ NUCLEAR FUEL BY TRAIN}

H. K. Elder

Project Coordinator

Technical Contributors

H. K. Elder

J. F. Friley

C. W. Stewart

September 1981

Prepared for Sandia National Laboratories' Transportation Technology Center for the United States Department of Energy under Contract DE-AC06-76RLO 1830

Pacific Northwest Laboratory

Richland, Washington 99352 
$\checkmark$

$-$ 


\section{PREFACE}

This study was initiated in FY 1979 in the Transportation Safety Studies Project performed at Pacific Northwest Laboratory (PNL) for the Department of Energy's (DOE) Division of Environmental Control Technology. In FY 1980, responsibility for this work was transferred to the Division of Transportation and Fuel Storage and overview of the work was assigned to the Transportation Technology Center (TTC) at Sandia Laboratories, DOE's lead laboratory for Nuclear Materials Transportation Technology. This work was substantially complete when the overview was assigned to TTC. Funds for incorporation of review comments and publication of this study have been provided to PNL through TTC. 


\section{ABSTRACT}

This report uses risk analyses to analyze the safety of transporting spent nuclear fuel for commercial rail shipping systems. The rail systems analyzed are those expected to be used in the United States when the total electricity-generating capacity by nuclear reactors is $100 \mathrm{GW}$ in the late 1980s. Risk as used in this report is the product of the probability of a release of material to the environment and the consequences resulting from the release. The analysis includes risks in terms of expected fatalities from release of radioactive materials due to transportation accidents involving PWR spent fuel shipped in rail casks. The expected total risk from such shipments is $1.3 \times 10^{-4}$ fatalities per year. Risk spectrums are developed for shipments of spent fuel that are 180 days and 4 years out-of-reactor. The risk from transporting spent fuel by train is much less (by 2 to 4 orders of magnitude) than the risk to society from other man-caused events such as dam failure and infrequent natural events such as meteorites. 


\section{CONTENTS}

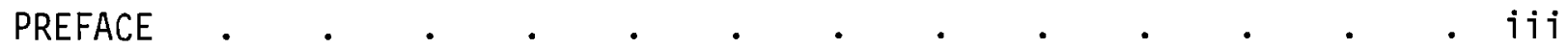
ABSTRACT

\subsection{SUMMARY}

1.1 OVERALL STUDY BASES

- iv

\subsection{STUDY RESULTS}

- $1-1$

2.0 INTRODUCTION

3.0 TRANSPORTATION RISK ANALYSIS METHODOLOGY

- $1-2$

3. 1 HISTORY

- $2-1$

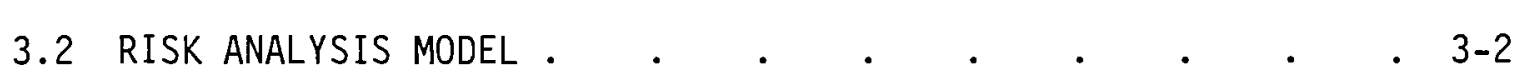

3.2.1 System Description . . . . . . . . . . 3-4

3.2.2 Release Sequence Identification . . . . . . 3-6

3.2.3 Release Sequence Evaluation . . . . . . . 3-7

3.2.4 Risk Calculation and Comparison . . . . . . 3-9

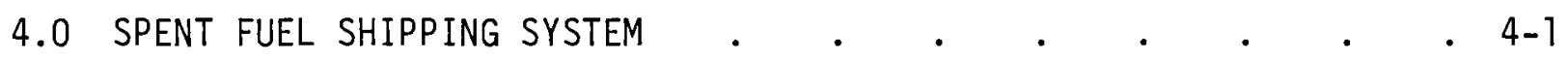

4.1 NUCLEAR INDUSTRY ASSUMPTIONS . $\quad . \quad \ldots \quad . \quad . \quad$. $4-1$

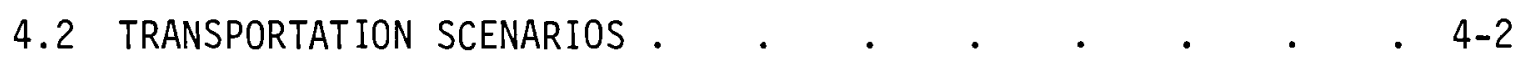

4.2.1 Once Through Fuel Cycle . . . . . . 4-2

4.2.2 Spent Fuet Reprocessing . . . . . . 4-3

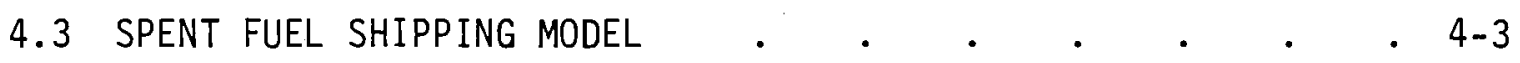

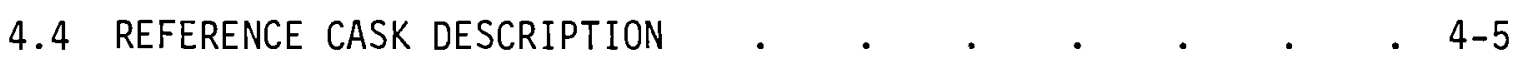

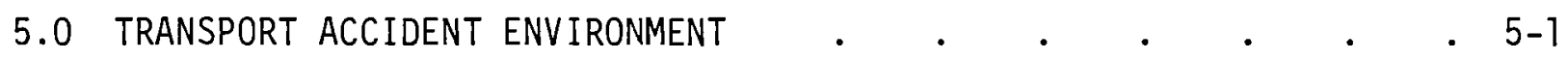

5.1 RAILCAR ACCIDENT RATES . $\quad . \quad$. $\quad . \quad$. $\quad . \quad$. $5-1$

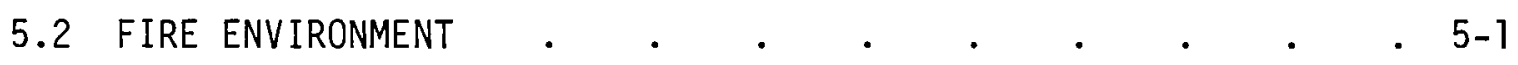

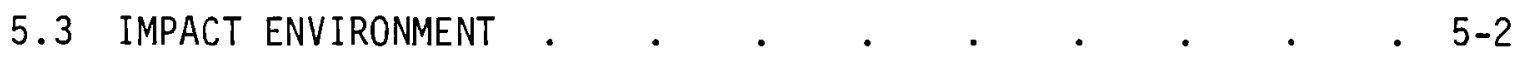

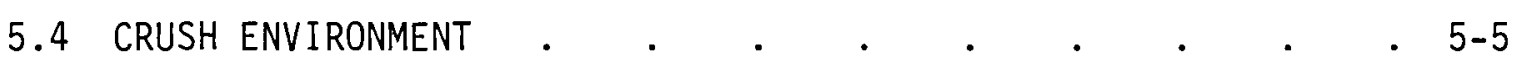


5.5 IMMERSION ENVIRONMENT $\quad . \quad \ldots \quad . \quad . \quad . \quad . \quad . \quad . \quad . \quad 5-5$

5.6 PUNCTURE ENVIRONMENT $. \quad . \quad . \quad . \quad . \quad . \quad$. $\quad . \quad 5-6$

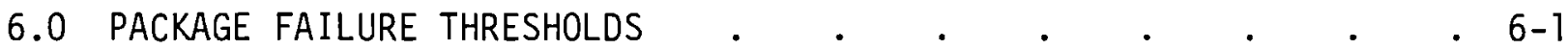

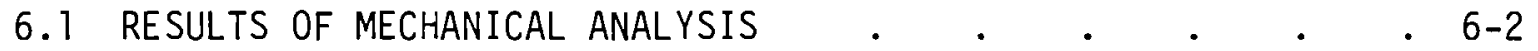

6.2 RESULTS OF THE THERMAL ANALYSIS . . . . . . . .

7.0 CONDITIONS OF SPENT FUEL CASK DURING TRANSPORT $\quad . \quad$ • $\quad$ • $7-1$

7.1 SCOPE OF SURVEY . . . . . . . . . . . . .

7.1.1 Packages Included in Survey . . . . . . . 7-1

7.1.2 Sites Included in Survey . . . . . . 7-2

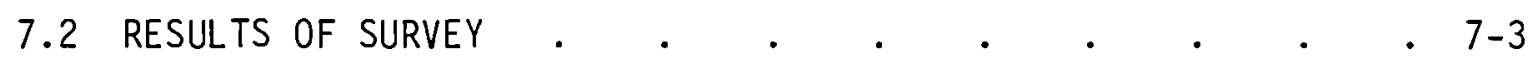

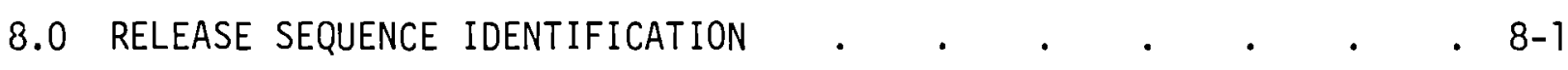

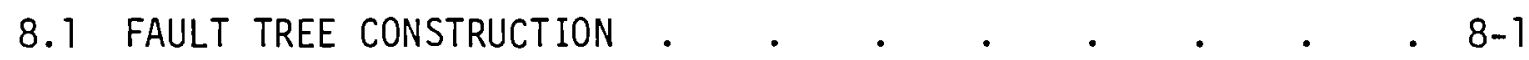

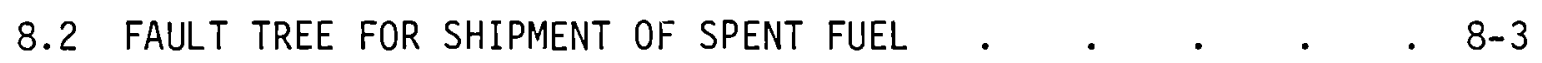

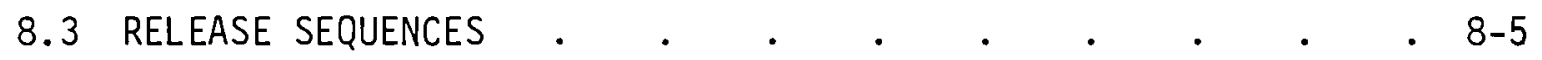

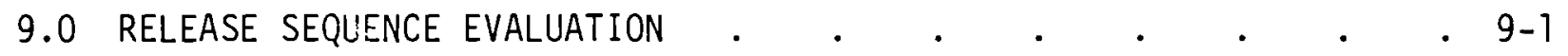

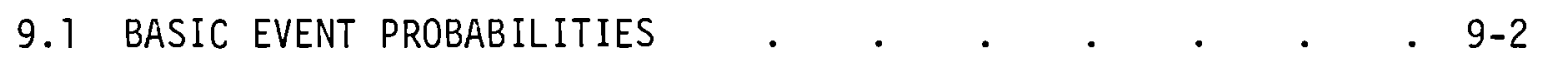

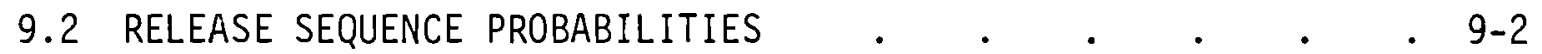

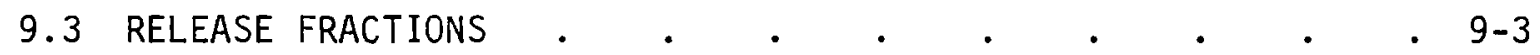

9.3.1 Material Available for Airborne Release . . . 9-4

9.3.2 Estimated Release Fraction for Various Release
Categories $. \quad . \quad . \quad . \quad . \quad . \quad . \quad . \quad .9-6$

10.0 EVALUATION OF ENVIRONMENTAL CONSEQUENCES $\quad . \quad$. $\quad . \quad$. $10-1$

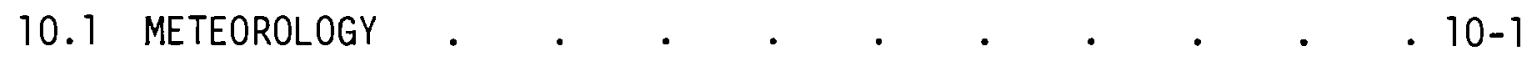

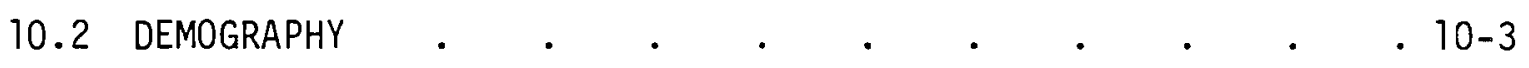

10.2.1 Population Zones Data . $\quad . \quad$. $\quad$. $10-4$

10.2.2 Average Size of an Urban Area . . . . . . 10-6 
10.2.3 Shipping Route Mileage by Population Zones . . 10-8

10.3 POPULATION DOSE FACTORS . . . . . . . . . . . 10-9

10.4 ATMOSPHERIC DISPERSION MODEL . . . . . . . . . . $10-5$

10.5 POPULATION HEALTH EFFECTS . . . . . . . . . $10-19$

10.6 ESTIMATED EXPOSURE FREQUENCY . . . . . . . . . 10-24

11.0 THE RISK OF SHIPPING SPENT FUEL BY TRAIN . • . • • . 11-1

11.1 RISK EVALUATIONS FOR SPENT FUEL SHIPMENTS . . . . 11-1

11.1 .1 The Risk Equation . . . . . . . . 11-1

11.1.2 The Risk of Shipping Spent Fuel for the Reference
Shipping System. 11-3

11.2 RISK SENSITIVITY STUDIES . . . . . . . . . . $11-8$

APPENDIX A - SPENT FUEL SHIPPING MODEL . . . . . . . . . A-1

APPENDIX B - DESCRIPTION OF REFERENCE SPENT FUEL RAIL SHIPPING CASK - B-1

APPENDIX C - MECHANICAL FAILURE THRESHOLD ESTIMATES FOR REFERENCE

SPENT FUEL RAIL CASK •

APPENDIX D - THERMAL ANALYSIS OF REFERENCE SPENT FUEL RAIL CASK • . D- 1

APPENDIX E - FAULT TREE FOR SHIPMENT OF SPENT FUEL BY TRAIN . . . E-1

APPENDIX F - BASIC EVENT PROBABILITIES . . . . . . . . F

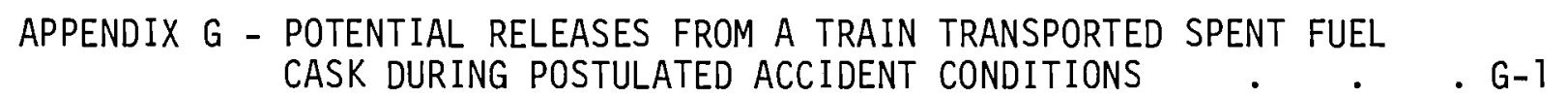

APPENDIX H - SIGNIFICANT RADIONUCLIDES IN SPENT FUEL . • • . $\cdot$ H-1

APPENDIX I - PATHWAYS OF RADIATION EXPOSURE TO MAN . . . . . I- 1 

.

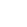




\section{FIGURES}

1.1 Risk Spectra for Spent Fuel Shipments by Train for $100 \mathrm{GW}$ Nuclear Capacities and for Other Events in the United States . 1-4

3.1 Model to Calculate the Risk of Shipping Energy Materials . . 3-5

4.1 U.S. Population Zones with Locations of Reactor Groups, Spent Fuel Storage Facilities and Reprocessing Plants . . . . 4-4

5.1 Duration Probability of Train-Fire Accidents Involving Large Packages . . . . . . . . . . 5-3

5.2 Velocity Changes Versus Frequency for Train Derailment Accidents . 5-4

5.3 Velocity Changes Versus Frequency for Train Collision Accidents . 5-4

5.4 Velocity Changes Versus Frequency for Train Accidents, A11 Types . 5-5

8.1 Spent Fuel Cask Rail Shipment Fault Tree . . . . . . 8-4

9.1 Remaining Steps in the Risk Evaluation . . . . . . 9-1

11.1 Risk Spectrum for Shipment of Spent Fuel to Interim Storage and Other Risk Spectra . . . . . . . . . . 11-5

11.2 Risk Spectra for Train Spent Fuel Shipments Expected About Midto-Late 1980s . . . . . . . . . . . 11-7

B.1 Reference Spent Fuel Shipping Cask . . . . . . . B-2

B.2 Reference Spent Fuel Shipping Cask in Normal Rail Transport

Configuration . . . . . . . . . . . B-3

C.1 Cask Closure End . . . . . . . . . . . . C-2

C.2 Cask Wall Section . . . . . . . . . . . C-3

C.3 Cask Closure End . . . . . . . . . . . C -3

C.4 View of End Impact Fins . . . . . . . . . . . C-4

C.5 Fuel Basket End View . . . . . . . . . . C -5

C.6 HONDO Mesh Used for the End Impact Model . . . . . C -7

C.7 End Deformation After 42.3-km/hr Impact . . . . . . C-10 
C.8 End Deformation After $60.4 \mathrm{~km} / \mathrm{hr}$ Impact . . . . . . C-10

C.9 End Deformation After $80.5 \mathrm{~km} / \mathrm{hr}$ Impact . . . . . . C-11

C.10 Lid Bolt Shear Motion for End Impact . . . . . . C-11

C.11 Cask Flange Strain in the Gasket Vicinity as a Function of Impact

Velocity. . . . . . . . . . . C-12

C.12 Annular Side-Impact Ring . . . . . . . . . C-13

C.13 HONDO Mesh Used for the Side-Impact Mode1 . . . . . C-15

C.14 Side Deformation After 32.2-km/hr Impact . . . . . C-15

C.15 Side Deformation After 96.6-km/hr Impact . . . . . C-15

C.16 Side Deformation After 144.8-km/hr Impact . . . . . C-15

C.17 Change in Cask Diamter Versus Side Impact Velocity . . . C-16

C.18 Component Strain Versus Side Impact Velocity . . . . . C-16

D. 1 Cask Noding Scheme . . . . . . . . . . D-3

D.2 Cask Node Connection Schematic . . . . . . . . . D-4

D.3 Normal Cooling Steady-State Temperature Distribution . . . D-6

D.4 Case 1 - Initial LOMC . . . . . . . . . . . . D-7

D.5 Case 2 - Initial LOMC and LOSW . . . . . . . D-8

D.6 Case 3 - Half-Hour Fire at $1010^{\circ} \mathrm{C}$. . . . . . . . D-9

D.7 Case 4 - Two-Hour Fire at $1010^{\circ} \mathrm{C}$. . . . . . . D-10

D.8 Case 5 - Initial LOCW, LOMS, and LOSW . . . . . . D-11

D.9 Dry Cask Steady-State Temperature Distribution . . . . D-11

D.10 Case 6 - Initial LOCW, LOMC, and LOSW Half-Hour Fire $1010^{\circ} \mathrm{C}$. . D-12

D.11 Case 7 - Initial LOCW, LOMC, and LOSW Half-Hour Fire $1300^{\circ} \mathrm{C}$. . D-13

D. 12 Case 8 - Initial LOCW, LOMC, and LOSW Two-Hour Fire $1010^{\circ} \mathrm{C}$. D-14

D.13 Case 9 - Initial LOCW, LOSW, and LOMC Forty-Minute Fire . . D-15

D.14 Case 10 - Dry Cask - Two-1/2-Hour Fire $1010^{\circ} \mathrm{C}$. . . . D-15

E.1 Spent Fuel Cask Rail Shipment Fault Tree . . . . . E-2

I.1 Exposure Pathways to Man . . . . . . . . . . I-2 
TABLES

1.1 Summary of Assumed Shipping Characteristics for Spent Fuel by Train

1.2 Average Total and Individual Risk in the United States from Various Accident and Natural Disasters . . . . . . 1-5

4.1 Nuclear Industry Assumptions . . . . . . . . 4-2

4.2 Shipping Characteristics for Spent Fuel by Train . . . . 4-5

5.1 Railroad Accident Fire Rates . . . . . . . . 5-2

5.2 Probability of Puncture . . . . . . . . . 5-6

6.1 Summary of Spent Fuel Cask Mechanical Failure Threshold Estimates. 6-4

6.2 Summary of Spent Fuel Cladding Mechanical Failure Threshold Estimates. . . . . . . . . 6-4

6.3 Time to Thermal Failure for Reference Spent Fuel Cask and Fuel . 6-6

7.1 Licensed and Available Shipping Casks for Current Generation LWR Spent Fuel . . . . . . . . . . . 7-2

7.2 Spent Fuel Cask Shipping Survey Results . . . . . . 7-4

8.1 Fault Tree Symbolism . . . . . . . . . . 8-2

9.1 Top 20 Release Sequences and Probabilities for Spent Fuel by Rail

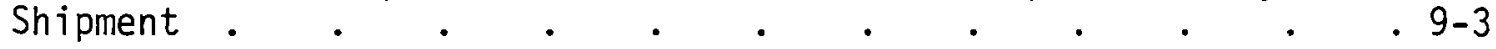

9.2 Accident Release Fractions to the Atmosphere from the Train Transport of 180-Day Cooled Spent Fuel . . . . . . . 9-7

9.3 Estimated Accident Release Fractions to the Atmosphere from the Train Transport of 4-Year Spent Fuel . . . . . . 9-8

9.4 Estimated Atmospheric Releases from the Transport of $3.22 \mathrm{MgHM}$ of 180-Day Cooled Spent Fuel . . . . . . . . 9-9

10.1 Average Wind Speed/Stability Characteristics . . . . . 10-2

10.2 New Jersey Population Characteristics-1960 . . . . . 10-5

10.3 Massachusetts Population Characteristics-1960 . . . . 10-5 
10.4 Missouri Population Characteristics-1960 . $\quad$ • . . . 10-5

10.5 Washington Population Characteristics-1960 . . . . . 10-6

10.6 Projected Population Density and Land Area by Zone and Population

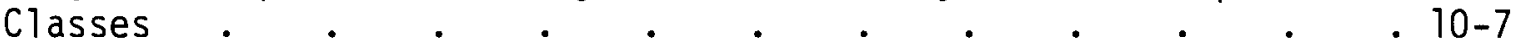

10.7 Calculated Overall Average Population Densitites by Zone • 10-7

10.8 Projected Land Area of Urban Areas in the Four Zones of the U.S. . . . . . . . . . . . . . .

10.9 Shipping Route Mileage by Population Zones . $\quad$ e $\quad$ • . 10-8

10.10 Population Dose Factors for Individual Isotopes . . . 10-12

10.11 Part A: Reference Mixture of Cesium Isotopes . . . . 10-13

Part B: Reference Mixture of Cesium and Ruthenium Isotopes . . 10-13

Part C: Reference Mixture of Fission Products . . . . 10-14

Part D: Reference Mixture of Actinides . . . . . . 10-14

10.12 Dose Conversion Factors for Reference Mixtures . . . . 10-15

10.13 Values of $\sigma_{y}$ for Pasquill Stability Categories . . . . 10-16

10.14 Values of $\sigma_{z}$ for Pasquill Stability Categories . . . . 10-17

10.15 Land Areas Within Isopleths of a Release Plume and More than $100 \mathrm{~m}$

from the Release Point . . . . . . . . 10-18

10.16 Land Area Contaminated Within $100 \mathrm{~m}$ of Accident Scene and Plume Centerline Value of UE/Q at $100 \mathrm{~m}$ Versus Pasquill Stability Classification.

10.17 Estimated Numbers of Deaths per Year in the Total U.S. Population Attributable to Continuous Exposure at a Rate of $0.1 \mathrm{rem} / \mathrm{yr}$, Based on Mortality from Leukemia and from all Other Malignancies

Combined

10.18 Assumed Values Used in Calculating Estimates of Risk Shown in Table 10.17

10.19 Health Effects Conversion Factors, Population Dose to Maximum Number of Health Effects. 
11.1 Shipping Characteristics for Spent Fuel by Train . . . . 11-3

11.2 Summary of Risk of Transporting Spent Fuel by Train • . . 11-4

11.3 Average Total and Individual Risk from Various Accidents and

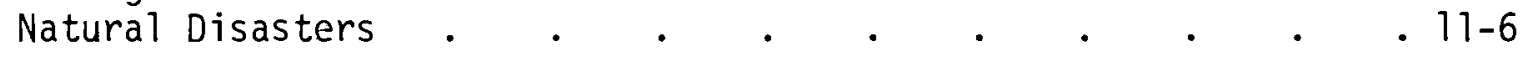

11.4 Risk Sensitivity Cases for Spent Fuel Shipments Expected in the

U.S. about Mid-to-Late 1980s . . . . . . . . . 11-9

A.1 Tabulation of Reactors and Reactor Groups . . . . . A-2

A.2 Spent Fuel Shipments by Train from Reactors to Storage Facilities A-7

A.3 Spent Fuel Shipments by Train from Reactors to Fuel Reprocessing Plants . . . . . . . . . . . . A-10

B.1 Characteristics of Design Basis Fuels and Cask . . . . B-4

B.2 Characteristics of Design Basis PWR Fuel . . . . . B-5

C.1 Mechanical Material Properties . . . . . . . C-9

E.1 Listing of Basic Events for Analysis for Spent Fuel Shipment
by Train. . . . . . E-15

E.2 Listing of Input Labels for Rectangles for Analysis of Spent

Fuel Shipment by Train . . . . . . . . . E-18

G.1 Analysis of Cladding Deposits . . . . . . . . G-3

G.2 Fraction of Nuclides Available for Release During Outgassing from Pellet-Cladding Gap. . . . . . . . . . G-4

G.3 Fraction of Spent Fuel Constituents Released to Coolant - . G-7

G.4 Fission Product Release from PWR-Type $\mathrm{UO}_{2}$ Irradiated to 7000
$\mathrm{MWd} / \mathrm{Mg}$ and Heated in Air to $700^{\circ} \mathrm{C}$ for $90^{\text {Minutes . . G-8 }}$

H.1 Significant Fission Products in Spent PWR Fuel . . . . H-3

H.2 Significant Fission Products in Spent PWR Fuel . . . . H-4

I.1 Pathways of Exposure to Man . . . . . . . . I-3

I.2 Contribution of Different Exposure Modes to Latent Cancer
Fatalities . . . . . . . I-4 


\subsection{SUMMARY}

This report presents the results of an analysis of the risk of shipping spent nuclear fuel by train. It is one of a series of risk studies on transporting energy materials, including an analysis of shipment of spent fuel by truck. (a) The primary purpose of this study is to quantitatively estimate the safety of transporting spent fuel by commercial shipping systems.

\subsection{OVERALL STUDY BASES}

The general risk analysis methodology used in this study is basically the same as that developed for the first study in this series. (1) General background is given in Section 2 and the methodology is summarized in Section 3. The analysis includes the risks from release to man's environment of spent fuel materials and radioactive cask cavity cooling water due to potential transportation accidents. The potential contribution to the risk of package misclosure and degradation during normal transport is also considered.

The results of the risk analysis are related to having nuclear plants with an electrical generating capacity of $100 \mathrm{GW}$ operating in the U.S., a situation that is expected in the mid-to-1ate 1980s. Because there is some uncertainty about the future development of the nuclear fuel cycle, two alternative transportation scenarios are considered: 1) the "once through" fuel cycle where all spent fuel is shipped to interim storage, and 2) the fuel reprocessing scenario where all spent fuel is shipped to reprocessing plants. Analysis of risk for the possibility of transporting spent fuel to disposal sites is not included. The important assumptions used for the analysis are:

- Shipping systems and regulations are the same as in 1979.

- Eighty percent of the spent fuel transported in the reference year is shipped by train.

- Spent fuel is assumed to be shipped either 180 days or 4 years after discharge from the reactor.

(a) The others are 1 isted as References $1,3,4,5,6$, and 7 . 
- The spent fuel is shipped in a commercially available rail cask with a capacity of seven (7) PWR or eighteen (18) BWR spent fuel elements.

The shipping system description developed from these assumptions is summarized in Table 1.1. Other shipping conditions or different shipping regulations could result in different risks than those reported in this study. However, the methodology is capable of analyzing the risks under any shipping conditions.

\section{TABLE 1.1 Summary of Assumed Shipping Characteristics for Spent Fuel by Train}

Spent Fuel Per Shipment (MgHM): (a)

PWR

BWR

Shipment: Origin/Destination:

Once Through Fuel Cycle

Reprocessing Fuel Cycle

Number of Reprocessing Plants:

Number of Interim Storage Facilities:

Material Shipped per Year by Train (MgHM):

Number of Shipments per Year by Train:

Average Shipment Distance $(\mathrm{km})$ :

Once Through Fuel Cycle

Reprocessing Fuel Cycle

Accident Probability (Number $/ \mathrm{km}$ ):
3.227

3.546
Reactor/Interim Storage
Reactor/Reprocessing Plant

2

4

1,474

471

912 (566 mi.)

$1,030(639 \mathrm{mi}$.

$6.2 \times 10^{-6}$

(a) Megagrams of heavy metal (uranium plus plutonium) in the original fuel.

\subsection{STUDY RESULTS}

For shipments from reactors to interim storage facilities, it is estimated that a train carrying spent fuel will be involved in an accident that would not 
be severe enough to result in a release of spent fuel material about once in 0.4 years. It is estimated that an accident that could result in a small release of radioactive material (primarily contaminated cooling water) would occur once in about 60 years. This accident would not be expected to result in measurable radiation doses to the general public or in significant contamination of property or equipment. The frequency of an accident resulting in one or more latent cancer fatalities from release of radioactive materials during a train shipment of spent fuel to interim storage is estimated to be once in 30,000 years. No accidents were found that would release sufficient radioactive materials to produce acute fatalities.

The risk for spent fuel shipments from reactors to reprocessing plants is estimated to be about $20 \%$ less than the risk for shipments to interim storage. Although the average shipment distance for the reprocessing case is larger, the risk was somewhat lower because the shipping routes, on average, are through less populated sections of the country. Given the uncertainty in the location of future fuel cycle facilities, this difference is judged to be insignificant.

The potential consequences of the postulated releases are estimated based on the characteristics and amount of radioactive material released to the environs, the probable weather conditions at the time of the accident, and the population density downwind from the accident scene. The likelihood and the consefuences for these postulated releases are coupled and expressed as risk spectra.

The risk spectrum for train shipment of spent fuel to interim storage is shown in Figure 1.1 for the number of annual shipments for the United States in this study. The risk spectrum is a plot of the estimated number of latent cancer fatalities versus the estimated frequency of an event resulting in that number of fatalities or greater. For example, the estimated probability that a train carrying 180-day cooled spent fuel may be involved in an accident resulting in one or more latent cancer fatalities during the reference year is $5.5 \times 10^{-5}$ and the estimated probability of an event resulting in ten or more fatalities is about $3.5 \times 10^{-6}$. Shipping only fuel that had been cooled 4 years would reduce the frequency of events producing one or more deaths to 


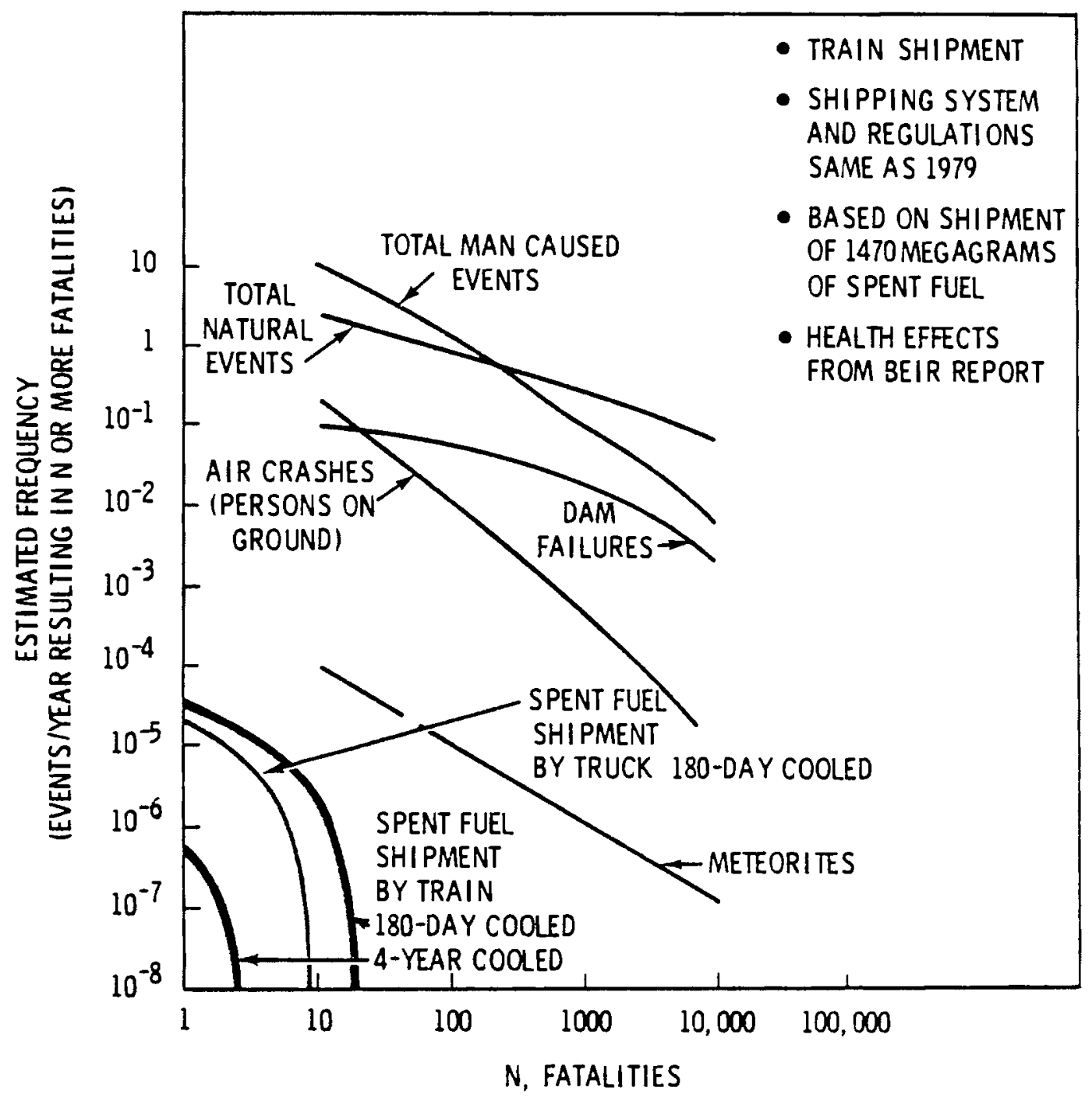

FIGURE 1.1. Risk Spectra for Spent Fuel Shipments by Train for 100 GW Nuclear Capacities and for Other Events in the United States

$8.3 \times 10^{-7}$. Risk spectra for other risks to which society is exposed ${ }^{(2)}$ and from transportation of spent fuel by truck ${ }^{(7)}$ are included in the figure for comparison. The risk from transporting spent fuel by train for the reference conditions is seen to be much less than the risk to society from natural events or man-caused events. It should be noted that the spectra for other societal risks include both latent (long-term) and acute (short-term) fatalities, whereas there are no acute fatalities related to the radiological consequences of shipping spent fuel. 
Additional perspective may be gained on the risk of transporting spent fuel by train by comparing the total risk and the risk to any individual in society with similar numbers for other risk-producing activities and natural events. The total risk from transporting 180-day cooled spent fuel by train in the reference year is $1.3 \times 10^{-4}$ fatalities. An individual in the population at risk ( 40 million) would have one chance in $1.1 \times 10^{11}$ of suffering a latent cancer fatality from a release of radioactive material from a train carrying spent fuel in the reference year. Table 1.2 presents a comparison of these numbers to other risk-producing events in the U.S. The risks from transporting spent fuel by train in the reference year are seen to be much less than the risks from other man-caused events and lower than the risk from infrequent natural disasters such as meteorites.

TABLE 1.2. Average Total and Individual Risk in the United States from Various Accidents and Natural Disasters

\begin{tabular}{|c|c|c|}
\hline Event & $\begin{array}{c}\text { Total } \\
\text { Risk (Fatalities/Year) } \\
\text { (a) }\end{array}$ & $\begin{array}{c}\text { Individual }_{\text {Risk }}^{(b)} \\
\end{array}$ \\
\hline All Accidents & 103,030 & 1 in 2,000 \\
\hline $\begin{array}{l}\text { Motor Vehicle } \\
\text { Accidents }\end{array}$ & 46,700 & 1 in 4,000 \\
\hline Air Crashes & 1,552 & 1 in 130,000 \\
\hline Dam Failures & $35^{(c)}$ & 1 in $5,700,000$ \\
\hline $\begin{array}{l}\text { Air Crashes } \\
\text { (Persons on Ground) }\end{array}$ & $6^{(d)}$ & 1 in $33,000,000^{(e)}$ \\
\hline Meteorites & $1.0 \times 10^{-3(f)}$ & 1 in $2 \times 10^{11}$ \\
\hline $\begin{array}{l}\text { Spent Fuel Train } \\
\text { Shipments }\end{array}$ & $1.3 \times 10^{-4}$ & 1 in $1.1 \times 10^{11(e)}$ \\
\hline $\begin{array}{l}\text { Spent Fuel Truck }(g) \\
\text { Shipments }\end{array}$ & $4.5 \times 10^{-5}$ & 1 in $6 \times 10^{11(e)}$ \\
\hline
\end{tabular}

(a) Based on 1975 statistics unless otherwise noted.

(b) Based on total U.S. population except where shown otherwise.

(c) Average for dam failures 1889-1972 (Reference 2).

(d) Average for years 1960-1973 (Reference 2).

(e) Based on population at risk.

(f) Estimate based on information from Reference 2.

(g) See Reference 7. 
The risk values derived in this study are believed to represent a conservative upper limit because of the assumptions used in the analysis. These assumptions include:

- conservative accident environment data

- conservative release fractions

- no corrective action taken in loss of cavity cooling situations.

Sensitivity studies were performed to determine the important contributors to the risk of spent fuel shipment by train. These studies are described in Section 11. Impact forces are found to contribute to about $84 \%$ of the releases and failure by fire contributed to only about $5 \%$. Accidents involving casks with nonstandard packaging conditions contributed to about $11 \%$ of the releases. To illustrate the sensitivity of the risk to the release fractions, it was assumed that all release fractions are increased by a factor of ten. This case represents an analysis that is believed to be very conservative. This is shown to increase the risk by a factor of about eight.

The spent fuel transported by train in the reference year will have been used to generate about $5 \times 10^{11} \mathrm{kWhr}$ of electricity or enough to provide the annual electrical energy requirement for a population of about 32 million people. Considering the substantial benefits derived from the fuel and the small risk involved in its shipment, and the comparison of this risk with that from other activities, it is the opinion of the authors that the current spent fuel transportation system poses reasonably low risks.

\section{REFERENCES}

1. T. I. McSweeney, R. J. Hall et al., An Assessment of the Risk of Transporting Plutonium 0xide and Liquid Plutonium Nitrate by Truck. BNWL-1846 Pacific Northwest Laboratory, Richland, Washington, August 1975.

2. Reactor Safety Study. "An Assessment of Accident Risks in U.S. Commercial Nuclear Power Plants." WASH 1400, U.S. Nuclear Regulatory Commission Washington, DC, October 1975.

3. R. J. Hall et a1., An Assessment of the Risk of Transporting Plutonium Dioxide and Liquid Plutonium Nitrate by Train. BNWL-1996, Pacific Northwest Laboratory, Richland, Washington, February 1977. 
4. T. I. McSweeney and J. F. Johnson, An Assessment of the Risk of Transporting Plutonium Dioxide by Cargo Aircraft. BNWL-2030, Pacific Northwest Laboratory, Richland, Washington, June 1977.

5. R. E. Rhoads et al., An Assessment of the Risk of Transporting Gasoline by Truck. PNL-2133, Pacific Northwest Laboratory, Richland, Washington, August 1978.

6. C. E. Geffen et al., An Assessment of the Risk of Transporting Uranium Hexafluoride by Truck and Train. PNL-2211, Pacific Northwest Laboratory, Richland, Washington, August 1978.

7. H. K. Elder et al., An Assessment of the Risk of Transporting Spent Nuclear Fuel by Truck. PNL-2588, Pacific Northwest Laboratory, Richland, Washington, November 1978. 


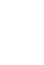
. 


\subsection{INTRODUCTION}

Radioactive materials, in a variety of physical and chemical forms, have been routinely transported between various nuclear facilities for many years. The safety record for these shipments has been excellent. As the nuclear industry grows, it is expected that the number of shipments made annually will increase. To ensure the health and safety of the general public, industry and government agencies are continually improving their level of understanding of the safetyrelated aspects of transporting energy materials including nuclear materials.

Research programs are one method of improving the level of understanding. Such a research program has been conducted by the Pacific Northwest Laboratory (PNL) for the Environmental Control Technology Division of the Department of Energy. The objectives of the program are to develop a methodology for quantitatively assessing the safety of transporting energy materials and to apply it to current and future shipping systems. Risk analys is was selected for these evaluations. Through analys is of risk, consequences of postulated releases of energy materials during transport can be put into perspective by viewing the events relative to their expected frequency of occurrence.

Risk, as used in this report, is the product of the probability of a release of material to the environment and the consequences resulting from the release. There are two basic ways to express risk that are important in a risk analysis, both of which are used in this report. The first is a numerical value which is the sum of the risks associated with each particular activity (e.g., all that occur with shipment of spent fuel). This is the total risk. In order to perform the summation, all risks have to be expressed with respect to the same time interval (e.g., per year) and in the same units (e.g., fatalities). Although the total risk is an important measure, it gives only the detriment (in this study, latent cancer fatalities) that would be expected on the average during the reference time interval. The magnitude of detriments from any one event are not discernable in the total risk value. For example, the risk associated with an accident that occurs once a year and results in one fatality is the same (i.e., one fatality/year) as that from an accident which occurs once in ten years but results in ten fatalities. 
The second way to express risk is by plotting the expected frequency of $N$ or more fatalities as a function of $\mathrm{N}$, with each type of accident appearing as a discrete point. The curve that is generated by connecting such points is called a risk spectrum. The risks associated with two activities are similar only if they have the same total risk (risk magnitude) and the same risk spectrum. Both risk measures are used in this report.

The basic risk analysis methodology used in this report was initially applied to the shipment of plutonium $(1)$ by truck and has subsequently been applied to the shipment of plutonium by rail ${ }^{(2)}$ and air, ${ }^{(3)}$ the shipment of gasoline by truck, ${ }^{(4)}$ the shipment of uranium hexafluoride by truck and rail ${ }^{(5)}$ and the shipment of spent fuel by truck. ${ }^{(6)}$ This report presents the results of an assessment of the risk of transporting spent nuclear fuel by train. The general risk methodology used in this assessment as well as the previous risk studies is also reviewed.

Sections of the report correspond to the specific anialysis steps of the risk assessment mode1. The transportation system and accident environments are described in Sections 4 and 5 . Calculation of the response of the shipping system to forces produced in transportation accidents are presented in Section 6 and the results of a survey to determine the condition of the package during transport are presented in Section 7 . Sequences of events that could lead to a release of radioactive material from the shipping cask during transportation are postulated in Section 8 using fault tree analysis. These release sequences are evaluated in Sections 9 through 11 , to determine both the likelihood and the possible consequences of each release. Supportive data and analyses are given in the appendices.

\section{REFERENCES}

1. T. I. McSweeney, R. J. Hall et al., An Assessment of the Risk of Transporting Plutonium Oxide and Liquid Plutonium Nitrate by Truck. BNWL-1846, Pacific Northwest Laboratory, Richland, Washington, August 1975.

2. R. J. Hall et al., An Assessment of the Risk of Transporting Plutonium Dioxide and Liquid Plutonium Nitrate by Train. BNWL-1996, Pacific Northwest Laboratory, Richland, Washington, February 1977.

3. T. I. McSweeney and J. F. Johnson, An Assessment of the Risk of Transporting Plutonium Dioxide by Cargo Aircraft. BNWL-2030, Pacific Northwest Laboratory, Richland, Washington, June 1977. 
4. R. E. Rhoads et a1., An Assessment of the Risk of Transporting Gasoline by Truck. PNL-2133, Pacific Northwest Laboratory, Richland, Washington, November 1978.

5. C. A. Geffen et a1., An Assessment of the Risk of Transporting Uranium Hexafluoride by Truck and Train. PNL-2211, Pacific Northwest Laboratory, Richland, Washington, August 1978.

6. H. K. Elder et a1., An Assessment of the Risk of Transporting Spent Nuclear Fuel by Truck. PNL-2588, Pacific Northwest Laboratory, Richland, Washington, November 1978. 


\subsection{TRANSPORTATION RISK ANALYSIS METHODOLOGY}

This risk evaluation is one of a series of analyses of the transportation of hazardous energy materials. The history of the methodology and a brief summary of the risk assessment model used in all studies to date are presented below.

\subsection{HISTORY}

The risk analysis methodology used in this and earlier risk transportation studies evolved from a number of risk analysis models originally developed for use in the nuclear industry. Initially, the risk analysis methodology was suggested as a method of selecting an acceptable site for nuclear power facilities. (1) Accident frequencies were expressed in the form of reactor years between radioactive material releases, and consequences were expressed in terms of the amount of radioactive material released.

Developments in the area of the health effects of exposure to radiation allowed the eventual use of individual mortality as the measurement of consequences of radionuclide releases to man's environment in later studies. $(2,3,4)$ The units of risk became the probability of an individual mortality in any operational year. Analyses $(5,6)$ were further expanded to show that the risk level that individuals are willing to accept is related to the benefits received by the individual. If the benefits are significantly higher, then the risk level the individual is willing to accept is also higher.

The use of health effects to express risk allows a variety of technologies to be meaningfully compared. In the Reactor Safety Study, ${ }^{(7)}$ the risk of operating a nuclear power plant was compared to the risks from natural disasters and man-caused events.

The risk analysis methodologies discussed above have been 1 imited to analyses of fixed facilities. These facilities have a well-defined population distribution and the population in the immediate vicinity of the plant (the exclusion area) is controlled by the facility operator. The population distribution in the vicinity of a transportation accident, however, is highly 
variable. Transportation accidents may occur in rural areas (with very low population densities) in suburban areas or in urban areas (with relatively high population densities). Since transportation accidents can occur at virtually any location along the shipping route, a variety of geographic and meteorological conditions can also be encountered. The variability in the population distribution, geography and meteorology for transportation accidents adds a degree of complexity not found in risk assessments of fixed sites.

A number of methodologies have been developed to analyze the transport of hazardous materials. One, used by the University of Southern California(8) in a study for the Department of Transportation, is based on accident case histories. This technique, however, cannot be applied to all energy material shipments because in many cases the accident experience is extremely limited or the accident data have not been collected in a way that permits accurate risk assessments.

A second technique developed by Holmes and Narver was used to determine the risk of transporting bioweapons ${ }^{(9)}$ and radioactive materials. $(10)$ These analyses were performed for shipments of material along a selected route. This methodology is limited in that one average number for the risk is obtained. It would also be beneficial to know how the risk varies with route, weather, population, material form, and accident severity. The variability of risk with possible transport conditions could then be considered.

\subsection{RISK ANALYSIS MODEL}

The risk analysis model used in the evaluations of the transport of energy materials is described below. The methodology used in the PNL risk studies provides flexibility to permit the risk to be analyzed for a spectrum of population densities and weather conditions that can be encountered along shipping routes.

The transportation risk analysis model provides a systematic method for handling the data required to analyze the safety of the transportation of hazardous materials. The model uses one fundamental equation: 


$$
R=\sum_{i}^{\Sigma} R_{i}
$$

The total system risk $R$ is the sum of the risks of all accidental releases, $R_{i}$. Only accidental releases are considered in the model. The risk of an individual release is the product of the consequences of the release and the probability of its occurrence. In the current formulation of the model, each term in Equation 3-1 is expanded into two expressions which have more physical significance. The expanded equation for $R_{i}$ is:

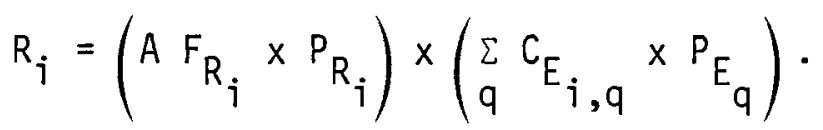

The first expression, $A F_{R_{j}} \times P_{R_{j}}$, can be thought of as a probabilistic source term for each identified release sequence. The first factor in this term, $A F_{R_{j}}$, represents the amount of material released in the $i^{\text {th }}$ release sequence. It $i s$ the product of the amount of material present in a shipment $(A)$ and the fraction of that material lost to the environment in the $i^{\text {th }}$ release sequence $\left(F_{R_{j}}\right)$. This factor can be considered a source term for the $j^{\text {th }}$ chain of events or failures which end with an accidental release of material. The second factor, $P_{R_{i}}$, is the probability that the release sequence will happen during transport.

The second expression in Equation 3-2 $\left({ }_{q}^{\Sigma} C_{E_{j}, q} \times P_{E q}\right)$ represents the consequences of a unit release of material (unit source term) under probabilistically weighted weather conditions and population distributions. The consequences of a unit release of material are evaluated in the expression $C_{E_{j, q}}$. The subscript $q$ denotes that this factor is a function of the specific weather conditions existing at the time of the release and the population exposed to the release. The consequences can be expressed in a variety of ways, depending on the material being studied. Risk comparisons can be made most advantageously if the consequences are expressed as health effects. The final factor in this expression, $P_{E_{q}}$, is the joint probability of encountering a particular set of weather conditions within a specific population zone. 
The methodology used to provide input data for solution of the above equations involves four components:

- System Description

- Release Sequence Identification

- Release Sequence Evaluation

- Risk Calculation

These four components, shown graphically in Figure 3.1 , are described in detail below. Step numbers correspond to the number shown in the figure.

\subsubsection{System Description}

The system description can be considered the what, how, when, and where component. The risk analysis is as good as the knowledge of the system through which the material is being shipped. For this study most of the information is already available or easily derived. A complete description of the transportation system generally consists of seven steps, which are shown in Figure 3.1.

Projected industry characteristics are determined in Step 1. Included in this segment is a description of projected facilities and industry needs for the reference year. Material type, amounts, origins, and destinations are specified in the second step. The third step presents a description of the important physical and chemical characteristics of the material being shipped. For example, an important property of liquid materials is the vapor pressure exerted as a result of elevated temperatures in an accident environment. Powdered materials require specification of the particle size distribution. For radioactive materials, the radionuclide inventory must also be specified.

In the remaining four steps, the transportation system is described. In Step 4, the transportation mode is specified, and the vehicles used are described. Weight and space limitations (and in the case of radioactive materials shipments, heat, geometry, dose and criticality limits) must be specified here so that amount of material per shipment and the required number of shipments can be calculated.

The container used to carry the material is considered in Step 5. For DOT specification or approved containers, only the container designation is 


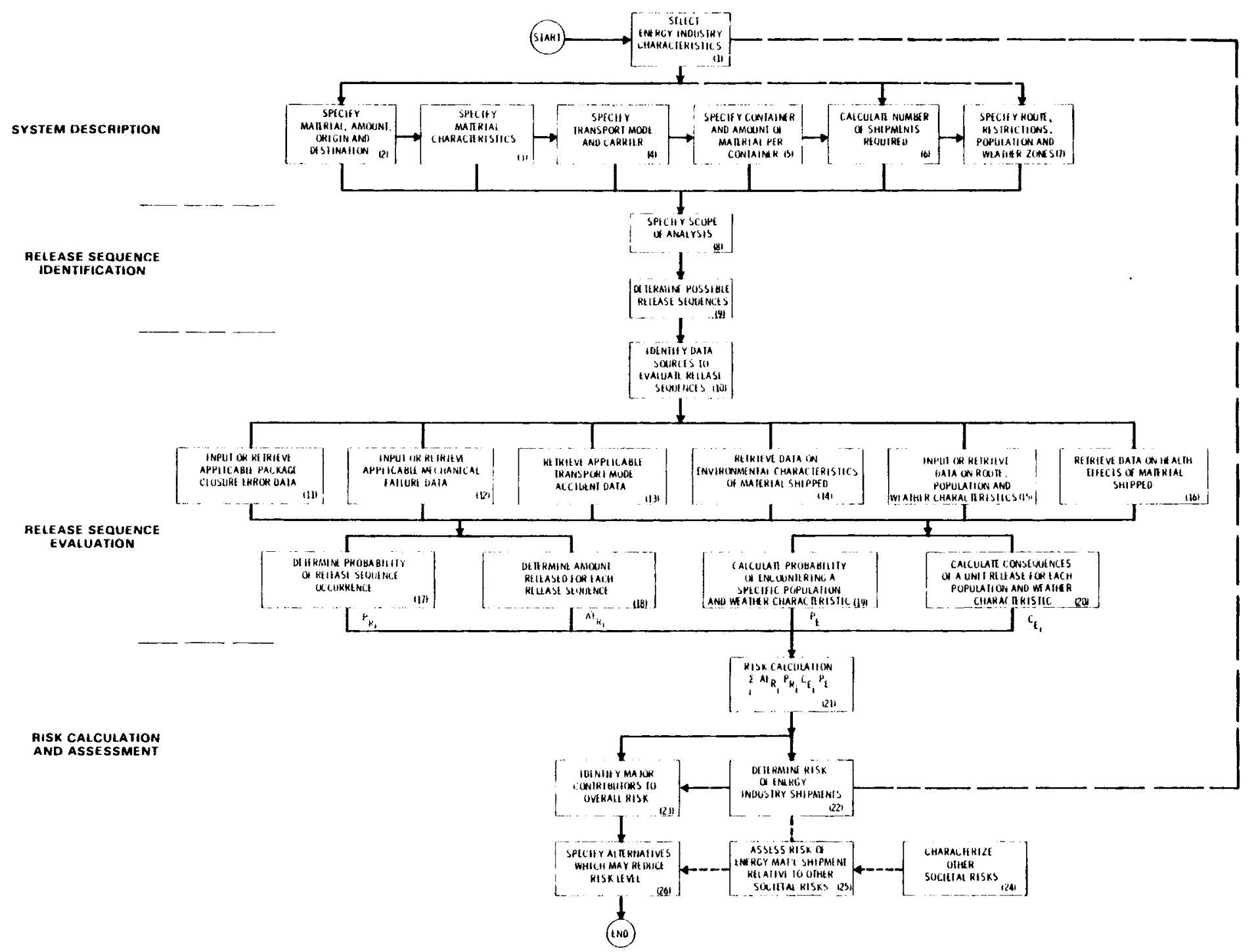

FIGURE 3.1. Model to Calculate the Risk of Shipping Energy Materials 
needed to completely describe the container. Nonstandard containers require sufficient input to permit evaluation of failure paths later in the analys is. Step 6 of the system description involves the calculation of the number of shipments required to transport the amounts of material specified in Step 2, in the vehicles and containers given in Steps 4 and 5 .

In the final step of the system description, the shipping route is divided and each segment is described in terms of type of route, shipping restrictions, population and weather characteristics. With the completion of this step, the entire transportation system has been described.

\subsubsection{Release Sequence Identification}

The next component in the risk assessment process is the identification of the sequences of events that could lead to release of material from the transport vehicle. These sequences of events, called release sequences, may be identified in a variety of ways. It is felt that the most complete listings of release sequences are obtained by deductive reasoning processes that work backwards from assuming a release through the possible chains of events that could produce the release. Fault tree analysis provides a systematic method for performing these deductive reasoning processes. The fault tree that is constructed in these analyses also provides a compact notation for displaying large numbers of release sequences. Computer codes such as the MFAULT ${ }^{(11)}$ code used at PNL, can be used to quickly and accurately perform the Boolean algebra that reduces the fault tree to a series of release sequences or "cut sets" required for subsequent steps in the analysis.

Before the possible release sequences are identified (Step 9), the scope of the sequence analyses must be delineated (Step 8). Only those release sequences within the selected scope of analysis are evaluated in the subsequent steps in the model. Completed studies using this risk assessment model have considered releases from two general causes. In addition to releases caused by forces produced in transportation accidents, releases resulting from package closure errors, substandard packaging construction or deterioration in packaging condition resulting from the normal transportation environment have been considered. Failure associated with deliberate sabotage or diversion attempts have not been considered. 


\subsubsection{Release Sequence Evaluation}

The release sequences which have been identified are evaluated to determine the factors needed to evaluate Equation 3-2. The source term (i.e., the amount of radionuclides released to man's environment) and environmental consequences evaluations are performed separately.

The release sequence factors (denoted by the subscript " $R$ " in Equation 3-2) represent the probability that material will be released in an accident and the amount of the material released. The evaluation of these factors requires the information from four data bases, shown in Figure 1 as Steps 11-14. These data bases are:

- Package Closure Error Data (11)

- Mechanical Failure Data (12)

- Transport Mode Accident Data (13)

- Data on Environmental Characteristics of Material Shipped (14)

Package closure data (Step 11) can be obtained in several ways. One method that has been used is to survey facilities routinely receiving the material under study. Physical container tests and mechanical failure analyses are used to develop data in Step 12. Studies already completed using the PNL model have used both accident environment information developed at Sandia Laboratories (12) and Department of Transportation accident data to satisfy Step 13. The behavior of the material in the environment (Step 14) depends entirely upon the material under consideration.

With the information from Steps 11 to 14, the probability of a release is evaluated and the source term for each release is characterized (Steps 17 and 18 in Figure 3.1). Generally, the probability of a release sequence occurring is evaluated first and the source term is then determined for the release sequences. Release fractions $\left(F_{R_{j}}\right)$ used for various release sequences and environmental conditions are determined after carefully examining the individual release sequences.

The environmental terms in Equation 3-2 are denoted by a subscript $E$. The factor $P_{E}$ represents the probability that a given set of weather and population density characteristics will be encountered. The factor $C_{E_{j}}$ represents 
the consequences of a unit release occurring in the region characterized by the weather and population density used to determine $P_{E}$. The consequences are initially calculated as a population dose in units of man-rem to a selected organ of reference and then converted to health effects.

The evaluation of the environmental consequences terms requires input from three data bases:

- Data on Environmental Characteristics of Material Shipped (14)

- Data on Route, Population, and Weather Characteristics (15)

- Data on Potential Health Effects of Material Shipped (16)

The environmental behavior characteristics and health effects from exposure to the released material is a function of the material itself and must be developed individually for each study. Data for Step 15 are available from many compilations including U.S. Census data $(13)$ and summaries of regional weather data compiled by the U.S. Weather Bureau. (14)

Information from Steps 14 to 16 is used to evaluate the probability of experiencing a given set of weather conditions and population characteristics. These evaluations are shown as Steps 19 and 20 in Figure 3.1. The $P_{E}$ term in Equation 3.2 is the probability associated with the weather and population characteristics. The expanded form of this term is given:

$$
P_{E_{j, k, 1}}=P_{j / k} \times P_{k} \times P_{1} \text {. }
$$

The subscripts $j, k$ and 1 refer to the multiplicity of environmental conditions which could exist at the location of the accident. For example, the variable $P_{j / k}$ may be the probability of experiencing the $j^{\text {th }}$ atmospheric stability classification when the $k^{\text {th }}$ windspeed exists, the variable $P_{k}$ the probability of encountering the $k^{\text {th }}$ windspeed category and the variable $P_{1}$ the probability of encountering a specified population distribution. 


\subsubsection{Risk Calculation and Comparison}

The final component in the risk analysis is to sum and evaluate the risks associated with the applicable release sequences. The steps involved in this component are shown graphically in Figure 3.1.

The overall risk calculation for each release sequence is described by Equations 3-1 and 3-2. These release sequence risks are added to determine the risk associated with individual shipping routes. The risks for individual routes are next weighted according to the amounts being shipped along each route. The overall transportation risk (total risk) is the sum of risks from these weighted individual routes. At this point, the risk can also be expressed in terms of a risk spectrum (plot of magnitude of consequence versus frequency of events resulting in that consequence or a more severe consequence). A risk calculating computer code, TRECII, developed at PNL for transportation risk analysis is used to calculate the risk and the risk spectrum.

Comparison of the individual risk terms permits identification of those sequences of events that are major contributors to the overall risk (Step 23). From this list of sequences, changes which could reduce the overall risk may be suggested.

Comparing the risk levels obtained in the analysis to risk levels from other technologies or the natural environment places the calculated risk levels in perspective. Step 24 provides values for other societal risks and comparisons are made in Step 25. If it is determined that the calculated risk is unacceptable, alternatives which may reduce the risk level can be specified (Step 26).

\section{REFERENCES}

1. F. R. Farmer, "Reactor Safety and Siting: A Proposed Risk Criterion." Nuclear Safety, $8: 539,1967$.

2. H. J. Otway and R. C. Erdmann, "Reactor Siting and Design from a Risk Viewpoint." Nuclear Engineering and Design, 13:365, 1970.

3. M. Meleis and R. C. Erdmann, "The Development of Reactor Siting Criteria Based Upon Risk Probability." Nuclear Safety, 13:22, 1972. 
4. G. D. Bell, "Safety Criteria: Quantitative Safety Analysis." Nuclear Engineering and Design, 13:183-244, 1970.

5. C. Starr, "Benefit-Cost Studies in Socio-Technical Systems." Proceedings of Conference on Hazard Evaluation and Risk Analysis, Houston, Texas, 18-19 August 1971, National Academy of Sciences, Washington DC.

6. C. Starr, M. A. Greenfield and D. F. Hausknecht, "A Comparison of Public Health Risks: Nuclear versus 0il Fired Power Plants." Nuclear News, 15(10):37, 1972 .

7. Reactor Safety Study. WASH-1400, U.S. Nuclear Regulatory Commission, Washington DC, October 1975.

8. G. P. Jones and R. W. Barrow, Risk Analysis in Hazardous Materials Transportation. RAPO-72-106, U.S. Department of Transportation, Office of Hazardous Materials, Washington DC, November 1972.

9. B. J. Garrick, W. C. Gekler, 0. C. Baldonado, H. K. Elder and J. E. Shapley, A Risk Model for the Transport of Hazardous Materials. HN-204, Holmes and Narver, Inc., Los Angeles, California, August 1969.

10. C. V. Hodge and 0. C. Baldonado, "Risk Analysis of Shipments in the Nuclear Power Industry." Proceedings of the 4th International Symposium on Packaging and Transportation of Radioactive Materials, CONF-740901, September 22-27, 1974.

11. P. J. Pelto, W. L. Purce11, MFAULT: A Computer Code for Analyzing Fault Trees. BNWL-2145, Pacific Northwest Laboratory, Richland, Washington, November 1977.

12. R. K. Clarke et al., Severities of Transport Accidents. SLA-74-0001, Sandia Laboratories, A7buquerque, New Mexico, Ju1y 1976.

13. U.S. Bureau of the Census, County and City Data Book, 1967, (A Statistical Abstract Supplement). U.S. Department of Commerce, Washington DC, 1967.

14. U.S. Weather Bureau, Climatological Data Summaries. U.S. Department of Commerce National Climatic Center, Asheville, North Carolina.

15. A. L. Franklin, TRECII: A Computer Program for Transportation Risk Assessment. PNL-3208, Pacific Northwest Laboratory, Richland, Washington, May $\overline{1980 .}$ 


\subsection{SPENT FUEL SHIPPING SYSTEM}

The risk analysis model discussed in Section 3 is based on a specific set of shipping requirements for the material being transported. The shipping requirements include the projected amounts of material to be shipped and the number, origin and destination of shipments in the time period studied. This evaluation is based on the number of operating power reactors to allow comparisons to be made with the relative risks involved in shipping other fuel cycle materials determined in earlier studies. $(1,2,3,4)$ Because of uncertainties in the future development of the nuclear fuel cycle, risk analysis for two spent fuel shipping scenarios, the "once through" fuel cycle and fuel reprocessing, were made in this study. Spent fuel shipping models for the two cases are presented in Section 4.3. A brief description of the spent fuel shipping cask is given in Section 4.4 .

\subsection{NUCLEAR INDUSTRY ASSUMPTIONS}

The analysis in this study is based on the spent fuel shipping requirements for a nuclear industry consisting of 100 nuclear reactors, each with 1,000 Megawatt electrical capacity (i.e., a total installed nuclear generating capacity of 100 Gigawatts electrical). This capacity level will probably be reached in the early to mid-1980s at the presently projected rate of growth. Fuel cycle facilities operating in the mid-1980s are assumed to be the same as those operating or in the planning or construction phase during 1979. The regulations governing shipping are assumed to be the same as in 1979. No significant changes in the nuclear industry are assumed to occur which would change the amounts of materials projected in the mid-1980s. The industry characteristic assumptions used in this evaluation are summarized in Table 4.1. A reactor plant capacity factor of approximately $65 \%$ is assumed. The amount of fuel shipped per year from the 100 reactors is estimated to be 1854 metric tons of heavy metal. (5) Converting this to the number of fuel assemblies shipped per year gives 2680 PWR fuel assemblies and 3275 BWR fuel assemblies shipped per year. 
TABLE 4.1. Nuclear Industry Assumptions

\begin{tabular}{|c|c|c|}
\hline \multirow[b]{2}{*}{ Number of Operating Power Reactors $(a)$} & \multirow{2}{*}{67} & \multirow{2}{*}{33} \\
\hline & & \\
\hline Reactor Generating Capacity & 1000 MWe & 1000 MWe \\
\hline Capacity Factor & $65 \%$ & $65 \%$ \\
\hline Total Weight of Fuel Shipped per $y^{(b)}$ & $1236 \mathrm{MgHM}$ & $618 \mathrm{MgHM}$ \\
\hline $\begin{array}{l}\text { Number of Assemblies Shipped per yr } \\
\text { from Reactors to Interim Storage or } \\
\text { Reprocessing Plants }\end{array}$ & 2680 & 3275 \\
\hline $\begin{array}{l}\text { Uranium and Fission Products per } \\
\text { Assembly }\end{array}$ & $461.4 \mathrm{~kg}$ & $197.0 \mathrm{~kg}$ \\
\hline
\end{tabular}

(a) Two-thirds of reactors are assumed to be PWR.

(b) Based on data derived from Reference 5.

\subsection{TRANSPORTATION SCENARIO}

Spent nuclear fuel may either be stored or reprocessed and used as additional reactor fuel. At the present time, reprocessing has been indefinitely deferred in the U.S. However, for completeness this study assesses the risk for spent fuel shipping scenarios associated with both the once through and the reprocessing fuel cycles.

\subsubsection{Once Through Fuel Cycle}

In the once through fuel cycle, spent fuel elements from nuclear power plants are shipped to an intermediate storage facility, and eventually sent to a permanent disposal facility. Irradiated fuel elements are cooled in a fuel storage basin at the nuclear reactor for at least six months after discharge. The fuel is then shipped by rail or truck to an interim storage facility. Some fuel may remain in reactor storage basins for longer than six months before shipment. After storage for about six years, the irradiated elements can then be packaged and shipped to a permanent disposal facility. No location or number of Federal repositories have been determined at this time and they will not be ready to receive spent fuel until after the mid-1980s; thus, those shipments are not considered in this study. 
It is assumed that there are four interim spent fuel storage facilities in operation in the United States in the reference year. These are assumed to be located at:

- Morris, Illinois

- Barnwe1l, South Carolina

- Oak Ridge, Tennessee

- Hanford, Washington

\subsubsection{Spent Fuel Reprocessing}

In the reprocessing fuel cycle, spent fuel is transported from reactors to a chemical reprocessing plant where the residual fissionable material is separated for eventual recycle in fresh reactor fuel. For purposes of this study, this scenario differs from the once through fuel cycle case only in the shipment destinations and the age of the fuel at shipment. For the reprocessing scenario, it was assumed that reprocessing facilities were located in Barnwe11, South Carolina and Oak Ridge, Tennessee.

\subsection{SPENT FUEL SHIPPING MODEL}

To determine estimated shipping route distances from reactors to spent fuel storage facilities or fuel reprocessing plants, a model shipping system was developed. Existing and proposed reactors ${ }^{(6)}$ are grouped according to type (PWR or BWR) and location, and distances from these groups to the nearest assumed interim storage or reprocessing facility are calculated. Locations of the reactor groups, spent fuel storage facilities and reprocessing plants are shown in Figure 4.1. Estimates of the amounts of spent fuel shipped per year from each reactor group are made based on the number, size and type of reactors in each group. From these amounts, the number of assemblies shipped are calculated. For this study, it is assumed that $80 \%$ of the spent fuel transported during the reference time period is shipped by train and that the fuel is shipped at either 180 days or 4 years after discharge from the reactor. The other $20 \%$ is assumed to be shipped by truck with the same shipping model assumptions. (7) Both of these cooling time periods after discharge are analyzed 


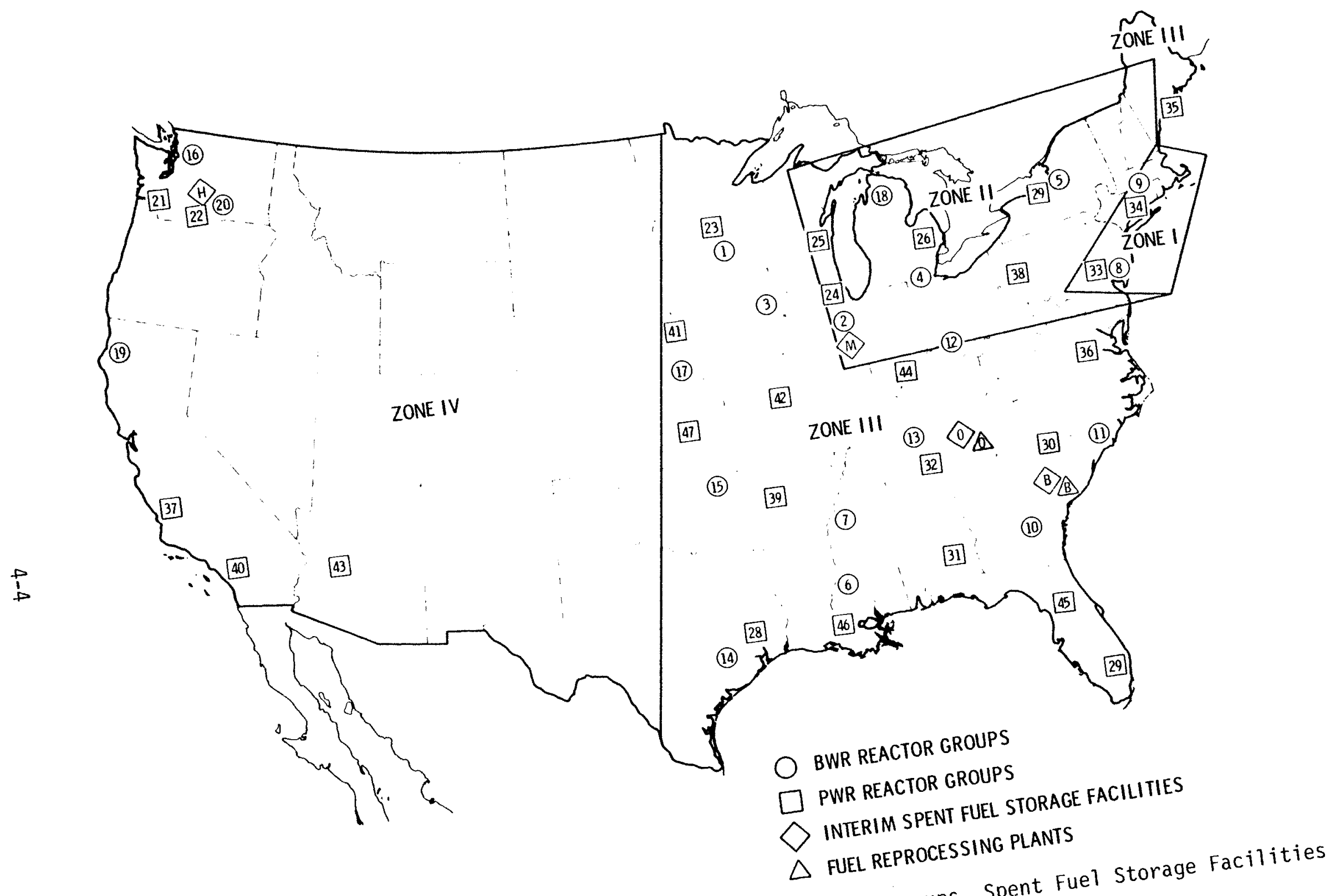

FIGURE 4.1. U.S. Population Zones with $\begin{aligned} & \text { and Reprocessing Plants } \\ & \text { and }\end{aligned}$ 
in the study. It is further assumed that shipments made in the mid-to-late 1980 s would be on main roads by licensed shippers. Table 4.2 shows the shipping characteristics assumed for analysis including the estimated shipping distances and number of train shipments. Details of the calculations of spent fuel shipping requirements are presented in Appendix $A$.

TABLE 4.2. Shipping Characteristics for Spent Fue1 by Train

\begin{tabular}{|c|c|c|}
\hline & $\begin{array}{l}\text { Once-Through } \\
\text { Fuel Cycle } \\
\end{array}$ & $\begin{array}{c}\text { Spent Fuel } \\
\text { Reprocessing }\end{array}$ \\
\hline $\begin{array}{l}\text { Shipment } \\
\text { Origin/Destination }\end{array}$ & $\begin{array}{l}\text { Reactor/ } \\
\text { Interim Storage }\end{array}$ & $\begin{array}{l}\text { Reactor/ } \\
\text { Reprocessing Plant }\end{array}$ \\
\hline $\begin{array}{l}\text { Age of Fuel at Shipment } \\
\text { (Time after Discharge } \\
\text { from Reactor) }\end{array}$ & $\begin{array}{l}180 \text { days and } \\
4 \text { years }\end{array}$ & 180 days \\
\hline $\begin{array}{l}\text { Number of Shipments per } \\
\text { Year by Train }\end{array}$ & 471 & 471 \\
\hline $\begin{array}{l}\text { Average Shipment } \\
\text { Distance; km }\end{array}$ & 912 (566 mi.) & $1030(639 \mathrm{mi})$. \\
\hline
\end{tabular}

\subsection{REFERENCE CASK DESCRIPTION}

Shipments of spent fuel are assumed to be made in a rail cask designed for transport of 7 PWR or 18 BWR fuel assemblies. Details of the cask are given in Appendix B. Removable fuel baskets and two different length closure heads are used to ship the two types of fuel. The approximate loaded cask weight is 63 megagrams $(140,000 \mathrm{lb})$. The gross weight of the cask, including skid and auxiliary components, is 84 megagrams $(185,000 \mathrm{lb})$. The cask is normally transsported by rail on a 100-megagram capacity, four-axle flatcar. The cask is enclosed during transport by an aluminum frame and expanded metal cage. Both gamma and fast neutron shielding are provided by water in the cask cavity, depleted uranium metal within the cask shell, and an exterior water-filled enclosure which is fabricated from thin-walled stainless steel and is corrugated to maximize the heat transfer area.

The closure head is sealed with a metallic gasket. The maximum normal operating pressure for the cask cavity is $1.4 \mathrm{MPa}$ (gage) (200 psig). Overpressure 
protection is provided by a pressure relief valve, with a discharge pressure of $2.6 \mathrm{MPa}$ (gage) (375 psig). The cask cavity is equipped with two nuclear service valves, one in each of two valve boxes, for filling, draining, venting and sampling. The shielding water containment is protected from overpressure by a 1.4-MPa (gage) (200-psig) relief valve. It is also serviced by fill and drain valves located in the two valve boxes. The outer surfaces of the cask body, including the cask ends and valve boxes, are finned for impact protection.

The cask inner cavity is a stainless steel cylinder, $95.2 \mathrm{~cm}(37$ 1/2-in.) ID with $1.27 \mathrm{~cm}$ thick walls, sealed with a $3.8 \mathrm{~cm}$ thick stainless steel bottom plate.

Surrounding the inner cavity is the depleted uranium metal shielding material. This heavy metal assembly consists of annular castings, each with a $97.8 \mathrm{~cm}$ ID and a $10.2 \mathrm{~cm}$ thick wall. The outer body shell is also a stainless steel cylinder with a $118.1 \mathrm{~cm}(46$ 1/2-in.) ID and a $3.8 \mathrm{~cm}$ thick wall.

Heat rejection is by convection through the water coolant in the cavity to the inner cask wall, conduction through the stainless steel and lead to the neutron shield, convection through the neutron shield to the outer wall, and forced convection plus radiation to the atmosphere. Maximum heat rejection capacity is $76.7 \mathrm{~kW}$ at worst-case atmospheric conditions. These conditions include still air at $55^{\circ} \mathrm{C}\left(130^{\circ} \mathrm{F}\right)$, direct exposure to sunlight, a full load of fuel with maximum fuel burnup and minimum cooling period. The allowable internal cavity conditions are $150^{\circ} \mathrm{C}\left(302^{\circ} \mathrm{F}\right.$ ) and $379 \mathrm{kPa}$ (gage) (55 psig). The primary cavity is designed to withstand temperature and pressure conditions of $212^{\circ} \mathrm{C}$ $\left(413^{\circ} \mathrm{F}\right)$ and $2.8 \mathrm{MPa}$ (gage) (400 psig) under the fire accident condition ( $1 / 2 \mathrm{hr}$ at a temperature of $\left.800^{\circ} \mathrm{C}\left[1475^{\circ} \mathrm{F}\right]\right)$.

A detailed description of the reference spent fuel shipping cask is given in Appendix B.

\section{REFERENCES}

1. T. I. McSweeney, R. J. Hall et al., An Assessment of the Risk of Transporting Plutonium 0xide and Liquid Plutonium Nitrate by Truck. BNWL-1846, Pacific Northwest Laboratory, Richland, Washington, September 1975. 
2. R. J. Hall et a1., An Assessment of the Risk of Transporting Plutonium Dioxide and Liquid Plutonium Nitrate by Train. BNWL-1996, Pacific Northwest Laboratory, Richland, Washington, February 1976.

3. J. F. Johnson and T. I. McSweeney, An Assessment of the Risk of Transporting Plutonium Dioxide by Cargo Aircraft. BNWL-2030, Pacific Northwest Laboratory, Richland, Washington, June 1977.

4. J. F. Johnson et a1., An Assessment of the Risk of Transporting Uranium Hexafluoride by Truck and Train. PNL-2211, Pacific Northwest Laboratory, Richland, Washington, August 1978.

5. C. M. Heeb et a1., ENFORM: An Energy Information System. BNWL-2195, Pacific Northwest Laboratory, Richland, Washington, March 1977.

6. Nuclear News. $20(10): 73$, August 1977.

7. H. K. Elder et al., An Assessment of the Risk of Transporting Spent Nuclear Fuel by Truck. PNL-2588, Pacific Northwest Laboratory, Richland, Washington, November 1978. 


\subsection{TRANSPORT ACCIDENT ENVIRONMENT}

Failure of a container during an accident occurs when the forces generated in an accident exceed the mechanical strength of a container. The forces or stresses which may be generated in the railcar accident environment and their likelihood of occurrence are discussed in this section. The estimated mechanical strength of the reference spent fuel cask is discussed in section 6 . The use of the results from Section 5 and 6 to estimate the likelihood of container failure in an accident is demonstrated in Section 9.

The railcar accident environment information used in this analysis were developed in a study by Dennis and others at Sandia National Laboratories. (1) Sandia's analysis characterizes the complex railroad accident environment by five categories of accident stresses that could affect a shipping package: impact, crush, puncture, fire, and immersion. Impact forces are defined as acting over a period of a few milli-seconds whereas crush forces can exist for several seconds following the accident. Impact forces are applied to one side whereas crush forces are applied from several directions. Impact and crush forces are adequately differentiated by comparing the force exerted by a hammer blow to the same force exerted by a press. Puncture stresses occur when a container is struck by an object that has potential for penetrating the container. Key information from the Sandia study used in this analysis is summarized in this section.

\subsection{RAILCAR ACCIDENT RATES}

Railcar accidents considered in the Sandia ${ }^{(1)}$ study include all accidents that result in railroad equipment, track, or roadbed damage in excess of $\$ 750$. The accident rate derived by Sandia which is used for this study is $6.2 \times 10^{-6}$ accidents per railcar kilometer. This rate is based on accident frequency data prepared by the U.S. Department of Transportation, which was compiled for the year 1972 .

\subsection{FIRE ENVIRONMENT}

Fire accident environment data used in this study were developed at Sandia. (1) Table 5.1 shows the relative frequency of various types of accidents, how 
TABLE 5.1. Railroad Accident Fire Rates (freight trains, damage $\$ 750)^{(1)}$

\begin{tabular}{|c|c|c|c|}
\hline $\begin{array}{l}\text { Accident } \\
\text { Type } \\
\end{array}$ & $\begin{array}{l}\text { Percent of } \\
\text { Total Accidents }\end{array}$ & $\begin{array}{c}\text { Percent of } \\
\text { Fire Frequency }\end{array}$ & $\begin{array}{r}\text { Percent } \\
\text { Total Fi } \\
\end{array}$ \\
\hline Collision & 6.62 & 1 & 0.74 \\
\hline Derailment & 83.39 & 1 & 9.38 \\
\hline Other & 9.99 & $90^{(a)}$ & 89.8 \\
\hline
\end{tabular}

(a) Due to a discrepancy in Sandia's sources, this value may be high.

often fire occurs in those accidents, and the percentage of the total fires according to type of accidents.

To determine the fire accident rate based on a train accident rate of $6.2 \times 10^{-6}$ accidents per railcar kilometer, the frequency data in Table 5.1 and the following information were used. The average number of cars involved in a fire following collision and/or derailment is 10 and the average number of cars involved in "other" train accidents where fire occurs is 1.2. The fire accident rate determined by Sandia was $1.7 \times 10^{-8}$ car fire accidents per car kilometer. (1)

The fire temperature has an expected range of $760^{\circ} \mathrm{C}$ to $1320^{\circ} \mathrm{C}$ with a mean value of about $1010^{\circ} \mathrm{C}\left(1850^{\circ} \mathrm{F}\right)$ and the duration of the fire can range from a few minutes to several hours. The expected duration of fires for railcar transport of large packages is shown in Figure 5.1. The temperature selected as representative for the railcar fire environment is $1010^{\circ} \mathrm{C}\left(1850^{\circ} \mathrm{F}\right)$.

Unlike truck fire accidents where at least partial exposure occurs for every fire, it is conservatively estimated that, given the fact that a package is on a train, close exposure in a train accident will occur no more than once in every ten fires. ${ }^{(1)}$

\subsection{IMPACT ENVIRONMENT}

The impact environment for an accident involving a large container such as a spent fuel cask is characterized by the expected velocity change that the car carrying the package would experience in the accident. Two accident 


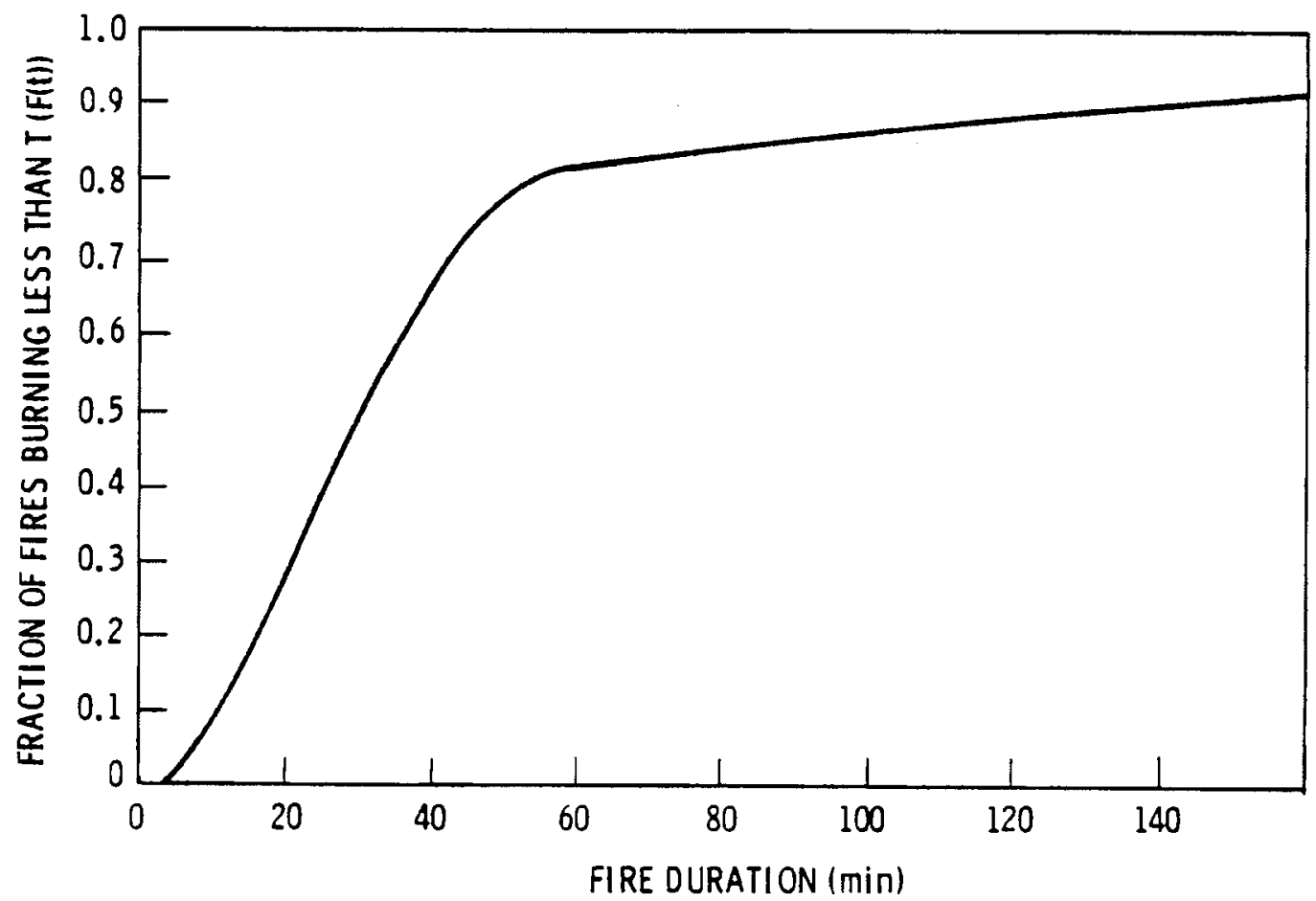

FIGURE 5.1. Duration Probability of Train-Fire Accidents Involving Large Packages

categories, as defined previously, were studied: the train derailment accident and the train collision accident. The "otiner" train accident category was found to have no significant impact conditions, thus the car of interest was considered to suffer no velocity changes due to these accidents. To determine the velocity change of the car of interest in derailment and collision accidents, computer programs using a Monte Cario analysis technique were prepared. Figures 5.2 and 5.3 show the velocity change versus the cumulative frequency of occurrence in derailment and collision accidents, respectively. The cumulative frequency of occurrence represents the fraction of cars having a velocity change equal to or less than that indicated. Figure 5.4 is a summary for all train accidents.

In these studies, the railcar environment, not the package environment, is predicted. However, for containers stronger than railcar structures, the abnormal environments predicted can be considered as the package environment. In this case, therefore, the package can be thought of as either impacting an adjacent car or being impacted by an adjacent car. 


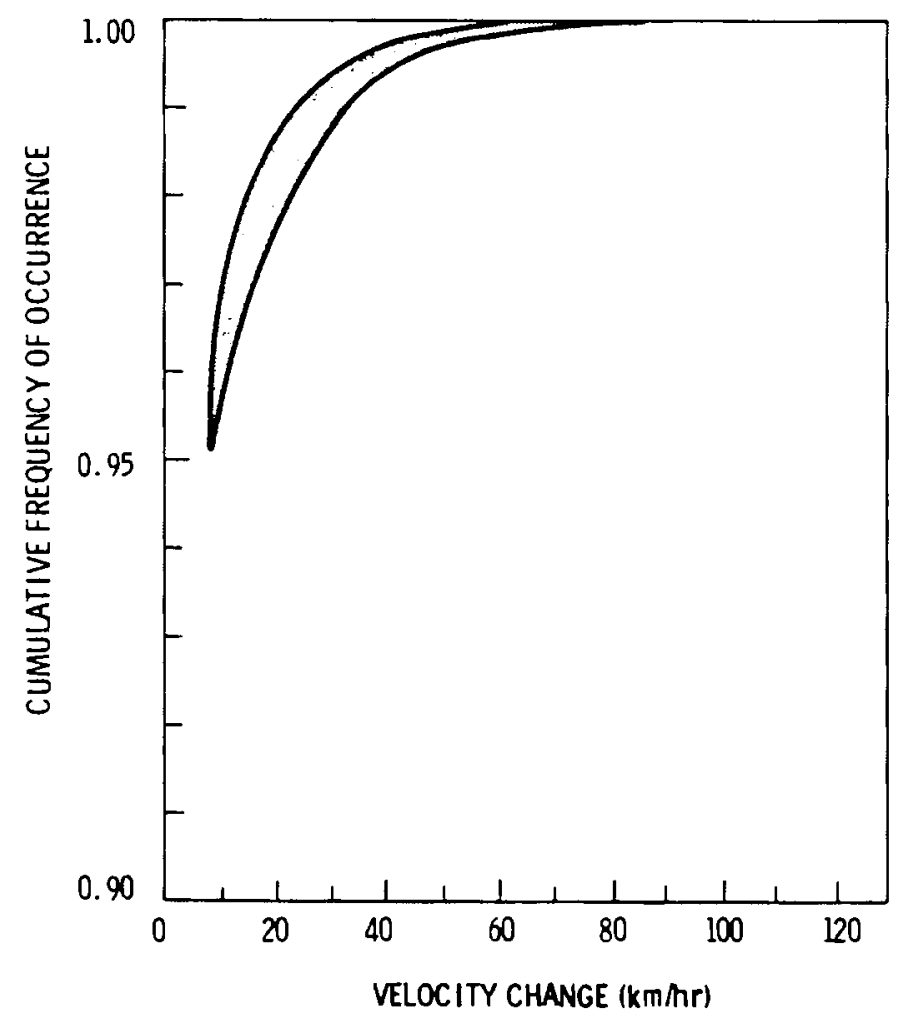

FIGURE 5.2. Velocity Changes versus Frequency for Train Derailment Accidents

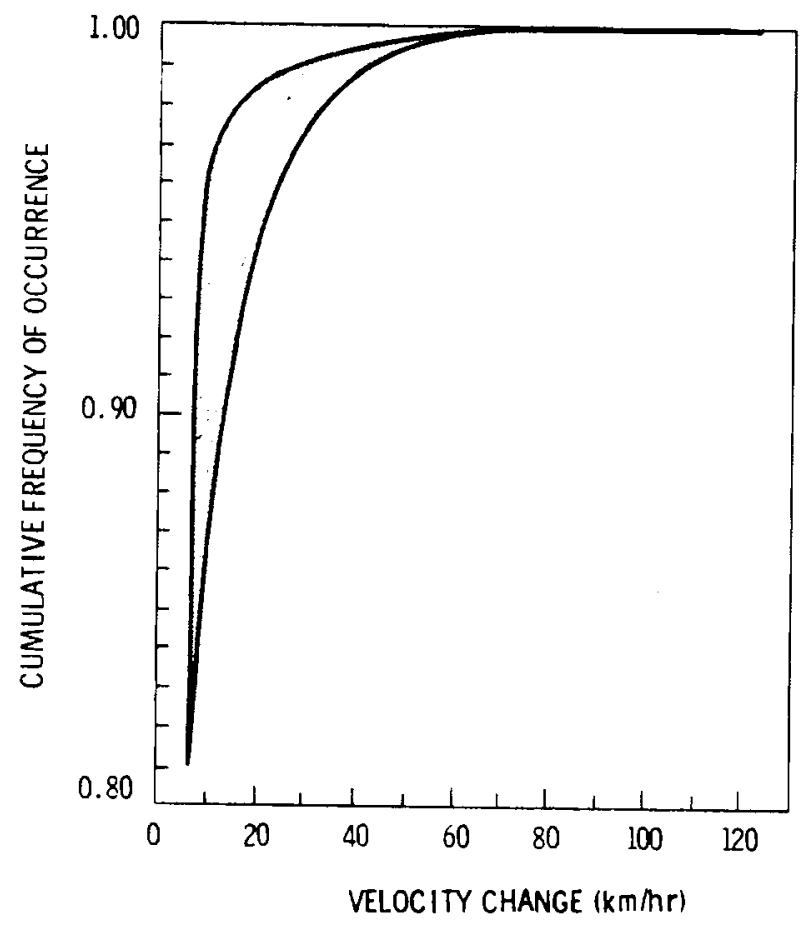

FIGURE 5.3. Velocity Changes versus Frequency for Train Collision Accidents 


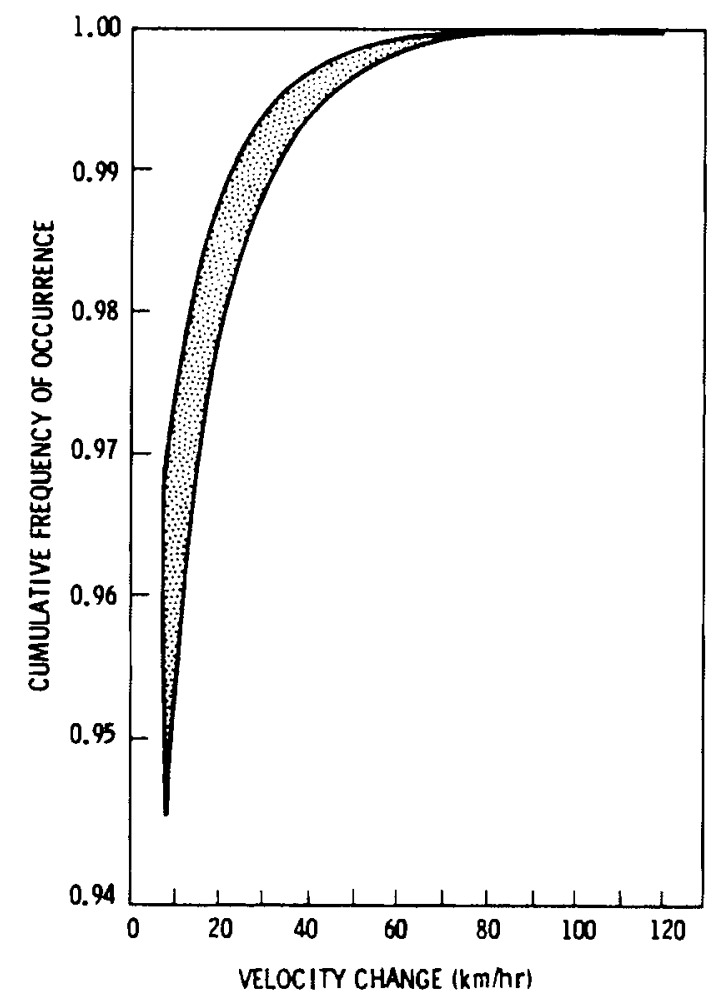

FIGURE 5.4. Velocity Changes versus Frequency for Train Accidents, A11 Types

\subsection{CRUSH ENVIRONMENT}

The railcar crush environment is difficult to quantify. The Sandia study (1) arbitrarily defined crush as "the essentially static forces acting on a package as a result of its position underneath derailed cars." Sandia analysis determined the probability of a container encountering accidentrelated crushing forces during transport and estimated the severity of those forces. The probability of crush was found to be $2 \times 10^{-3}$ per car accident and the probability of a static crush load of greater than $45,360 \mathrm{~kg}(100,000$ 1b) was less than $6.2 \times 10^{-10}$ per car-kilometer.

\subsection{IMMERSION ENVIRONMENT}

Insufficient data are available to be used directly for analysis of immersion resulting from a rail accident. However, through the use of indirect 
data, one potential immersion accident can be modeled as to probability of occurrence. The accident considered is that which occurs as a result of car derailment off a bridge that crosses a principal stream.

Sandia estimated the probability of this type of accident occurring to be $1.2 \times 10^{-11}$ per car-kilometer, and the probability of exceeding a depth of $15 \mathrm{~m}$ is about $3.1 \times 10^{-12}$ per car-kilometer. Even if other potential accidents were included, and the distance between bridges underestimated, the 15-m immersion probability value would still be less than $3.1 \times 10^{-10}$ per car-kilometer.

\subsection{PUNCTURE ENVIRONMENT}

The Sandia study described puncture environment using information on puncture of railroad tank cars in train accidents. The railcar coupler was assumed to be representative of potential railroad puncture threats. Because of the relative strength of the package, coupler failure was considered. The results of the Sandia (1) study are given in Table 5.2 .

TABLE 5.2. Probability of Puncture

\begin{tabular}{|c|c|}
\hline $\begin{array}{r}\text { Package Wall } \\
\text { Thickness, } \mathrm{cm} \text { (in.) }\end{array}$ & $\begin{array}{l}\text { Probability per } \\
\text { Transport Kilometer } \\
\end{array}$ \\
\hline $1.11(0.4375)$ & $4.62 \times 10^{-9}$ \\
\hline $1.27(0.50)$ & $4.29 \times 10^{-9}$ \\
\hline $1.91(0.75)$ & $3.64 \times 10^{-9}$ \\
\hline $2.54(1.00)$ & $3.05 \times 10^{-9}$ \\
\hline $3.18(1.25)$ & $2.60 \times 10^{-9}$ \\
\hline $3.81(1.50)$ & $2.09 \times 10^{-9}$ \\
\hline $4.45(1.75)$ & $1.51 \times 10^{-9}$ \\
\hline $5.08(2.00)$ & $9.45 \times 10^{-10}$ \\
\hline $6.35(2.50)$ & $1.96 \times 10^{-10}$ \\
\hline $7.62(3.00)$ & $2.92 \times 10^{-11}$ \\
\hline $10.16(4.00)$ & $3.44 \times 10^{-13}$ \\
\hline $12.70(5.00)$ & $5.85 \times 10^{-17}$ \\
\hline $15.24(6.00)$ & -- \\
\hline
\end{tabular}




\section{REFERENCE}

1. A. W. Dennis, J. T. Foley, W. F. Hartman and D. W. Larson, Severities of Transportation Accidents Involving Large Packages. SAND77-0001, Sandia Laboratories, A1buquerque, New Mexico, November 1977. 
- 


\subsection{PACKAGE FAILURE THRESHOLDS}

The environment imposed on large containers during rail accidents has been described in the previous section. Package response to the most significant stresses imposed in railway accidents is estimated in terms of failure thresholds. Estimates of the failure thresholds for the train-transported spent fuel cask are presented in this section. A failure threshold is the level of applied thermal or mechanical stresses that could potentially produce a release of radioactivity to man's environment in an accident. Failure points of containers are distributed in stress level. There is a most probable level that will result in failure, but in any group of "identical" containers there are some that will fail above or below this most probable value. The results of this section must be used in conjunction with other information on the stresses to which the package may be exposed in order to assess whether or not the package will fail in the accident environment. These assessments are made in Sections 9 and 11 .

The package failure threshold estimates presented here were obtained using mathematical analysis and engineering estimates. The analysis that was performed provides results that are within the overall accuracy range of this risk assessment, and it is believed that they provide a conservative estimate of the rail shipping system risk. Cask mechanical response estimates were made in two analysis steps using energy absorption theories of structural behavior modeled on a finite element computer code. The failure estimates obtained using these methods are believed to be less than the actual strength of the container if tests to failure had been performed. The degree of conservatism is unknown. Analysis can be performed to show the sensitivity of the overall system risk to various assumptions and calculational techniques. Based on the sensitivity studies discussed in Section 11, the techniques used to estimate failure thresholds do not appear to introduce significant error into the risk assessment. The failure thresholds should not, however, be used in assessing cask integrity for purposes other than those for which they are used in this analysis. 
The rail cask analyzed in this report is described in Appendix $B$. The detailed stress analysis for the package and spent fuel is given in Appendix $C$ (Mechanical Failure Threshold Estimates for Reference Spent Fuel Rail Cask). Details of the thermal calculations for the cask in fire and loss of cavity coolant situations are presented in Appendix D (Thermal Analysis of Reference Spent Fuel Rail Cask).

Two barriers to release of radioactive material are present for the spent fuel cask. These barriers are the fuel rod cladding and the spent fuel cask body. Relatively small amounts of radioactivity are present in the cavity coolant and are released if the cask body is breached. A11 larger releases of radioactivity from the cask must breach both the fuel and the cask. The failure thresholds estimated in this section are derived for both the fuel and cask.

The most significant types of accident-imposed stresses which affect the spent fuel cask and fuel are:

- End Impact

- Side Impact

- Fire

- Impact followed by Fire

The response of the cask and fuel to each type of stress associated with the accident environment is calculated independentiy.

The puncture threat to a cask is based on the equivalent steel thickness of large packages. No analysis of the response of the cask to the immersion environment was performed because the accident environment analysis showed that such an environment would not be a significant contributor to the risk of shipping spent fuel by rait.

\subsection{RESULTS OF MECHANICAL ANALYSIS}

Cask failure analyses considered for this risk assessment were made in two steps. In the first step, energy absorption analyses of the crushable sacrificial fins were performed. In the second part of the analysis, the response of the cask body was modeled and analyzed using a finite element 
mode1. (1) These steps were performed to predict failure thresholds which are assumed for this study to result in cask failure due to distortion of sealing surfaces and cavity penetration closure devices. Impact velocities which could result in a breach of the cask cavity to the surrounding atmosphere were determined by the same methods. Energy requirements for these types of failure are then used to calculate minimum cask impact velocities.

Fuel cladding mechanical failure thresholds were calculated using elastic and energy absorption models. Irradiated material properties were considered in the analysis. Internal pressure and dynamic loadings were the principal stress contributors.

Failure thresholds for accidents considered in the mechanical analysis included: 1) end impact onto a rigid planar target, 2) end impact to overpressurize the rupture disk, 3) side impact onto a flat rigid target, 4) side impact onto a column, 5) crushing of cask, 6) end impact resulting in a large breach of cask body and 7) fuel pin failure thresholds for both end and side impact. These types of accidents were considered to be the most significant with respect to contribution towards the total risk of transporting spent fuel. All postulated accident conditions which could cause cask failure were determined to be in excess of cask licensing design requirements. Minimum failure velocities for the various mechanical environments are presented in Table 6.1. The indicated velocities are cask impact velocities with no consideration of energy absorption by the cask tie-downs or the railcar. This is considered to be conservative at lower impact velocities where the railcar and cask tie-down system could absorb a significant amount of energy. However, at higher velocity collisions, the energy absorbed by the transport system would probably be negligible. The impact accident environment data presented in Section 5.3 takes into account the relative hardness of targets in the Monte Carlo simulation techniques used to derive the data. The neutron shield would fail during any significant impact accident which would result in damage to the cask. No crushing environments were identified which could fail the cask body.

Fuel cladding failure thresholds are reported in Table 6.2. The end impact results in a cladding failure due to shear stresses. Side impacts cause failures in tension with the fuel supported as a beam between the grid spacers. 


\section{TABLE 6.1 Summary of Spent Fuel Cask Mechanical}

Failure Threshold Estimates(a)

\begin{tabular}{|c|c|c|c|}
\hline & Target & $\begin{array}{l}\text { Cask Velocity } \\
\mathrm{km} / \mathrm{hr} \text { (mph) }\end{array}$ & Failure Type \\
\hline \multirow[t]{2}{*}{ End Impact } & Rigid Plane & $81 \quad(50)$ & Seal to Cask Cavity \\
\hline & Rigid Plane & $105 \quad(65)$ & $\begin{array}{l}\text { Larger Opening to Cask } \\
\text { Cavity }\end{array}$ \\
\hline \multirow[t]{2}{*}{ Side Impact } & Rigid Plane & $76 \quad(47)$ & Seal to Cask Cavity \\
\hline & $\begin{array}{l}\text { Non-Flat } \\
\text { Target }\end{array}$ & $28 \quad(17)$ & Seal to Cask Cavity \\
\hline
\end{tabular}

(a) Taken from Appendix C.

(b) Sharply pointed targets, such as a tunnel abutment. (The very low probability of hitting this type of target must be considered in the analysis.)

\section{TABLE 6.2 Summary of Spent Fuel Cladding Mechanica
Estimates Failure Threshold}

\begin{tabular}{cccc} 
& $\begin{array}{c}\text { Cask Velocity } \\
\mathrm{km} / \mathrm{hr} \text { (mph) }\end{array}$ & & Failure Type \\
\cline { 2 - 3 } End Impact & $66(41)$ & & $\begin{array}{l}\text { Rods Fail at a } \\
\text { Single Point }\end{array}$ \\
Side Impact & $52(32)$ & & $\begin{array}{l}\text { Possible Multiple } \\
\text { Cladding Failures } \\
\text { on Each Rod }\end{array}$
\end{tabular}

(a) Taken from Appendix C.

\subsection{RESULTS OF THE THERMAL ANALYSIS}

The analysis of the response of the cask to heating environments present in rail accidents was performed with a special purpose computer code which considers a physical system as a collection of discrete volumes interconnected by appropriate heat flow paths. Thermal failures of both the cask and fuel cladding were considered for several fire and loss of coolant situations. Thermal failure of the cask due to fire was assumed to occur when a cask 
component fails and radioactive material can be released to the atmosphere. The various basic events that lead to failure are identified in Section 8 through development of fault trees. The thermal analysis was based on a decay heat load for PWR fuel of $8.5 \mathrm{~kW}$ per assembly for short-cooled (180-day) fuel and $1.4 \mathrm{~kW}$ per assembly for long-cooled (4-year) fuel. The analysis provides the information to determine the duration of a fire to cause various types of thermal failure and the time to failure for loss of coolant from other accident forces.

It was assumed that the cavity coolant would be released from the cask through the pressure relief valve when the mean cavity pressure reached $1.7 \mathrm{MPa}$ (gage) (250 psig). As the fuel temperature increases due to self-heating after the coolant is lost, the pressure in the fuel pins increases. This results in a hoop stress in the fuel pin cladding. Fuel pin failure occurs when the hoop stress exceeds the creep rupture strength of the Zircaloy 4 tubing. Smith ${ }^{(2)}$ estimated that some PWR cladding will fail above $570^{\circ} \mathrm{C}\left(1050^{\circ} \mathrm{F}\right)$ and all fuel elements would fail above $690^{\circ} \mathrm{C}\left(1300^{\circ} \mathrm{F}\right)$ at the pressure of $1.7 \mathrm{MPa}$ (gage) (250 psig) remaining in the cask. With cask failure from mechanical forces, the fuel elements are estimated to fail at lower temperatures since there would only be $1 \mathrm{~atm}$ pressure in the cask.

Table 6.3 presents the length of time to failure of the fuel elements for the cases analyzed in Appendix D. The information in Table 6.3 is used in the analysis to determine the length of time over which a release occurs for the various fire accident cases, impact followed by fire, and the loss of coolant case. All fire situations considered in this study are more severe than the cask 1 icensing requirements. 
TABLE 6.3. Time to Thermal Failure for Reference Spent Fuel Cask and Fuel

\section{Accident Case ${ }^{(a)}$}

1. Initial Loss of Mechanical Cooling

2. Initial Loss of Mechanical Cooling and Shield Water (no fire)

3. $1 / 2$-Hour Fire ${ }^{(\mathrm{C})}$ at $1010^{\circ} \mathrm{C}$ $\left(1850^{\circ} \mathrm{F}\right)$

4. 2-Hour Fire ${ }^{(\mathrm{C})}$ at $1010^{\circ} \mathrm{C}$

5. No Fire with an Initial Loss of Cavity Coolant $(d)$

6. $1 / 2$-Hour Fire ${ }^{(\mathrm{C})}$ at $1010^{\circ} \mathrm{C}$ with an Initial Loss of Cavity Coolant

7. $1 / 2$-Hour Fire ${ }^{(\mathrm{C})}$ at $1300^{\circ} \mathrm{C}$ $\left(2400^{\circ} \mathrm{F}\right)$ with an Initial Loss of Cavity Coolant

8. 2-Hour Fire at $1010^{\circ} \mathrm{C}$ with Initial Loss of Cavity Coolant

9. 2-1/2-Hour Fire ${ }^{(\mathrm{C})}$ at $1010^{\circ} \mathrm{C}$ with No Cavity Coolant in Cask and 4-year Cooled Fuel
Time of Loss Time to Initial of Coolant (hr) Fuel Clad Failure (hr)
33

10

2

$--$

$--$

$--$

$--$
15

3.5

5.0

3

2

2

$2(\text { hot } \operatorname{rod})^{(e)}$

2-1/2 (cold rod)

(a) See appendix for description of cases described.

(b) Time shown is for the hot rod to reach $570^{\circ} \mathrm{C}\left(1050^{\circ} \mathrm{F}\right)$ unless noted otherwise.

(c) Time zero at start of fire.

(d) Time zero when loss of coolant occurs.

(e) With 2-1/2-hour fire, the coldest rod reaches $570^{\circ} \mathrm{C}\left(1050^{\circ} \mathrm{F}\right)$.

(f) The hottest rod reaches $570^{\circ} \mathrm{C}\left(1050^{\circ} \mathrm{F}\right)$ at 2 hours.

\section{REFERENCES}

1. S. W. Kay, HONDO, A Finite Element Computer Program for Large Deformation Dynamic Response of Axisymmetric Solids. SLA-74-0039. Sandia Laboratories, Albuquerque, New Mexico, Apri1 1974.

2. C. W. Smith, Calculated Fuel Rod Perforation Temperatures Commercial Power Reactor Fuels. NEDO 10093, General Electric Company, San Jose, California, September 1969. 


\subsection{CONDITIONS OF SPENT FUEL CASK DURING TRANSPORT}

A data bank of package conditions during transport was developed for the spent fuel tuck shipment risk report. (1) To perform a detailed risk analysis of spent fuel transport, it was necessary to determine the package condition during normal transport. The data were obtained by a survey of industries and of government laboratories that received spent fuel for storage or processing. The results of this survey are presented in this section.

\subsection{SCOPE OF SURVEY}

The initial step in developing the survey was to determine the information which was needed for the data bank. The analysis traced the steps of package loading and closure and the normal transport environment to identify conditions that could affect package containment integrity. Based on the information identified in the analysis, questionnaires were prepared for use in the survey of the nuclear industry. The survey covers the time period from 1970 to 1977 with most of the available data in the period 1973 to 1976.

\subsubsection{Packages Included in Survey}

The purpose of the survey was to provide a broad practicable data base to evaluate packaging conditions during transport. Thus a broad class of spent fuel shipping casks were covered in the survey including both truck and rail casks. Most commercial spent fuel casks will accept either PWR or BWR spent fuel by using different fuel baskets; however, some are designed only for a particular type of fuel. Table 7.1 gives information about commercial shipping casks that are currently licensed and available for LWR spent fuel shipments in the United States.

Since the number of commercial cask shipments that have occurred in the United States has been 7 imited, the survey included other noncommercial casks that have been used to ship spent reactor fuel. The material shipped in these casks were similar to commercial fuel. The type of packaging and handling of the casks were also similar. The results presented below include the entire survey, both commercial and noncommercial fuel shipments. When differences 
TABLE 7.1. Licensed and AvaiTable Shipping Casks for Current Generation LWR Spent Fue 1

\begin{tabular}{|c|c|c|c|c|c|c|c|c|c|}
\hline \multirow{2}{*}{$\begin{array}{c}\text { Cask } \\
\text { Designation }\end{array}$} & \multicolumn{2}{|c|}{ Number of } & \multirow{2}{*}{$\begin{array}{c}\begin{array}{c}\text { Approximate } \\
\text { Loaded }\end{array} \\
\text { Cask Weight, Mg } \\
\end{array}$} & \multirow{2}{*}{$\begin{array}{c}\text { Usual } \\
\text { Transport } \\
\text { Mode } \\
\end{array}$} & \multicolumn{2}{|c|}{ Shielding } & \multirow{2}{*}{$\begin{array}{r}\text { Cavity } \\
\text { Coolant } \\
\end{array}$} & \multirow{2}{*}{$\begin{array}{l}\text { Maximum Heat } \\
\text { Removal, } \mathrm{kW} \\
\end{array}$} & \multirow[b]{2}{*}{ Status (1979) } \\
\hline & & BWR & & & Gamma & Neutron & & & \\
\hline $\begin{array}{l}\text { NFS }-4 \\
(\text { NAC - 1) }\end{array}$ & 1 & 2 & 23 & Truck & $\begin{array}{l}\text { Lead and } \\
\text { steel }\end{array}$ & $\begin{array}{l}\text { Borated } \\
\text { water and } \\
\text { antifreeze }\end{array}$ & Water & 11.5 & $\begin{array}{l}6 \text { casks } \\
\text { available }\end{array}$ \\
\hline NFS - 5 & 2 & 3 & 25 & Truck & $\begin{array}{l}\text { Uranium } \\
\text { and steel }\end{array}$ & $\begin{array}{l}\text { Borated } \\
\text { water and } \\
\text { ant / freeze }\end{array}$ & Water & 24.7 & $\begin{array}{l}\text { SAR } \\
\text { submit ted }\end{array}$ \\
\hline NLI $1 / 2$ & 1 & 2 & 22 & Truck & $\begin{array}{l}\text { Lead, } \\
\text { uranium } \\
\text { and steel }\end{array}$ & Water & Helium & 10.6 & $\begin{array}{l}5 \text { casks } \\
\text { available }\end{array}$ \\
\hline $\mathrm{TN}-8$ & 3 & & 36 & Truck $(\mathrm{a})$ & $\begin{array}{l}\text { Lead and } \\
\text { steel }\end{array}$ & $\begin{array}{r}\text { Borated } \\
\text { solid } \\
\text { res in }\end{array}$ & Air & 35.5 & Licensed \\
\hline TN-9 & & 7 & 36 & $\operatorname{Truck}^{(a)}$ & $\begin{array}{l}\text { Lead and } \\
\text { stee } 1\end{array}$ & $\begin{array}{l}\text { Borated } \\
\text { solid } \\
\text { res in }\end{array}$ & Air & 24.5 & Licensed \\
\hline IF -300 & 7 & 18 & 63 & $\operatorname{Ra} i_{1}^{(b)}$ & $\begin{array}{l}\text { Uranium and } \\
\text { stee } 1\end{array}$ & $\begin{array}{l}\text { Water and } \\
\text { anti freeze }\end{array}$ & Water & $76^{(c)}$ & $\begin{array}{l}4 \text { casks } \\
\text { available }\end{array}$ \\
\hline NLI $10 / 24$ & 10 & 24 & 88 & Rail & $\begin{array}{l}\text { Lead and } \\
\text { steel }\end{array}$ & Water & Hel ium & $97^{(d)}$ & $\begin{array}{l}2 \text { casks } \\
\text { available }\end{array}$ \\
\hline
\end{tabular}

(a) Overweight permit required.

(b) Truck shipment for short distances with overweight permit.

(c) Licensed decay heat load is $62 \mathrm{~kW}$.

(d) Licensed decay heat load is $70 \mathrm{~kW}$.

occurred in the data, if possible, those data relating to commercial fuel were relied on more heavily than the noncommercial fuel. By including as much data as practicable, a broader data base for the survey could be obtained.

Specific commercial spent fuel containers covered in the survey are: NFS-4, NLI 1/2, IF-100, and IF-200 truck casks and the IF-300 rail cask. The survey includes noncommercial casks used by government laboratories and the Naval reactors program.

\subsubsection{Sites Included in Survey}

The companies and laboratories asked to participate in the survey included:

General Electric Company

Morris Operation

Morris, IL

Allied Chemical Corporation Idaho Chemical Programs

Operation Office

Idaho Falls, ID
Nuclear Fuel Services, Inc. West Valley, NY

E. I. duPont de Nemours Savannah River Laboratory Aiken, SC 
U.S. Department of Energy

Pittsburgh Naval Reactors Office

West Mifflin, PA

\subsection{RESULTS OF SURVEY}

A copy of the questionnaire with overall results of the survey is shown in Table 7.2. The total number of shipments covered in the survey from 1970-77 is 3,795 shipments. This includes 3,581 truck and 214 rail shipments. It should be emphasized that in the experience sampled by the survey, a loss of packaging integrity of a spent fuel cask has never been observed. There have been several accidents involving spent fuel casks; however, no radioactive material has been released in these accidents. $(2,3)$ The survey does not include data on any casks that were involved in accidents. Supplementary information obtained from the survey respondents used in the analysis is provided in the comments section of Table 7.2.

Even though the information obtained in the survey provides a reasonably good base for the risk assessment model, certain 1 imitations should be recognized. First, for the most part, the observations were made by personal recollections. Consequently, the time period of the observations were not entirely certain. Secondly, in the years since 1971, Quality Assurance (QA) and Quality Control (QC) requirements have been strengthened by the NRC resulting in a reduction in packaging errors. Considering these factors, the results presented in Table 7.2 are believed to represent the best available data on present day spent fuel handling and packaging conditions. 


\section{TABLE 7.2. Spent Fuel Cask Shipping Survey Results}

Toeal to.

of Truck

ano Rat 1

Shipinents

A. Shipments of Spent Fuel Received

1977

1976

1975

1974

1973

1972

1971

1970

Pre-1970 If Avallabie)

Total 1970-77

Total

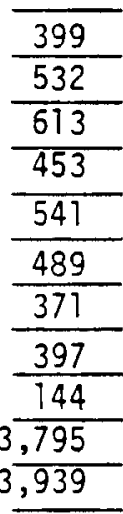

Shipants iruex

Shipments

$\begin{array}{r}\frac{384}{482} \\ \hline \frac{594}{429} \\ \hline \frac{522}{470} \\ \hline \frac{350}{350} \\ \frac{0}{3,581} \\ 3,581 \\ \hline\end{array}$

Rail

Shipments

\begin{tabular}{c}
\hline 15 \\
\hline 50 \\
\hline 19 \\
\hline 24 \\
\hline 19 \\
\hline 19 \\
\hline 21 \\
\hline$\frac{47}{144}$ \\
\hline 214 \\
\hline 358 \\
\hline
\end{tabular}

1. What was the maximum cask internal pressure on arrival?

2. Number of casks received with coolant pressure above normal operating range

3. Number of casks designed with impact limiters received with impact limiters not instatled.

4. Number of casks designed with impact limiters received with impact limiters not instalied correctly.

5. Number of casks received with cask hold-down broken or failed during shipment

6. Number of casks received with cask hcid-down not safety wired at time of shipment.

7. Number of casks received with low fuel cooling water level (not shipped dry)

8. Number of licensed "dry" shipments of spent fuel casks

9. Number of casks received with low neutron shield water levels (casks which have neutron shield water)

10. Number of casks containing spent fuel subjected to freezing with damage caused by treezing.

11. Number of casks received with higher external radiation readings than permitted on shipment release survey.

12. Number of casks received with shipping damage incurred in route (Note damage which was incurred in comments section.)

13. Number of casks dropped durirg handling procedure. (Note details of any damage in comments section.)

\begin{tabular}{|c|c|c|}
\hline $\begin{array}{l}\text { Truck } \\
\text { and Rat } \\
\text { Shipments }\end{array}$ & $\begin{array}{c}\text { iruex } \\
\text { shioments }\end{array}$ & $\begin{array}{c}\text { Rail } \\
\text { Shipments }\end{array}$ \\
\hline $\begin{array}{c}0-240 \text { xpa } \\
(\text { gage) } \\
(0-35 \text { psig) }\end{array}$ & $\begin{array}{l}124 \mathrm{kpa} \\
\text { (gage) } \\
\text { (13 osig) }\end{array}$ & $\begin{array}{r}240 \mathrm{kPa} \\
(\mathrm{gage}) \\
(35 \mathrm{psig})\end{array}$ \\
\hline 0 & 0 & 0 \\
\hline 0 & 0 & 0 \\
\hline $\begin{array}{l}1 \text { of }(2) \\
536\end{array}$ & $\begin{array}{l}1 \text { of }(2) \\
536\end{array}$ & 0 \\
\hline $9^{(3)}$ & $9^{13}$ & 0 \\
\hline 0 & 0 & 0 \\
\hline 0 & 0 & 0 \\
\hline 98 & 55 & 43 \\
\hline 0 & 0 & 0 \\
\hline 0 & 0 & 0 \\
\hline 5 & 5 & 0 \\
\hline 0 & 0 & 0 \\
\hline 0 & 0 & 0 \\
\hline
\end{tabular}

"If accurate numbers are nat avalable. approxımate values or estimates based on best recallections can be used and are requested.

: Please identity any casiks listed here in the comments secticn. 
TABLE 7.2. (contd)

C. Cask Lid Condition

1 Number of casks received with closure bolis not properly torqued tovertoraved. undertorqued)

2. Number of casks received with missing closure boits.

a. Number of closure bolts missing.

3. Numbar of casks received with closure bolts damaged in transit.

D. Closure Seal Condition

1. Number of casks received with closure seat damaged in transit.

2. Number of casks received with closure seal not installed properiy.

3. Number of casks received with incorrect closure seai installed.

4 Number of casks received with closure seal leakıng.

E. Cavity Penetration Conditions

1. Number of casks received requiring defective drain vaive replacement.

2. Number of casks received requiring defective vent vaive replacement.

3. Number of casks received requiring defective pressure retief device replacement.

4. Number of casks received with drain vaive not closed.

5. Number of casks recerved with vent valve not ctosed.

6. Number of casks received with drain valve not instalied properly

8. Number of casks received with pressure relief device not installed properiy.

9. Number of casks received with cavity penetration damaged during transit. (Note details of damage in comments section.)

10. Number of casks received with drain valve requiring replacement due to wear

11. Number of casks received with vent valve requiring reolacement due to wear

\begin{tabular}{c} 
Truck \\
And Aati \\
Shiomonts \\
\hline
\end{tabular}

\begin{tabular}{lll}
$\frac{6^{(4)}}{\frac{1}{1(5)}}$ & $\frac{6^{(4)}}{1}$ & $\frac{0}{1(5)}$ \\
$\frac{0}{0}$ & $\frac{0}{0}$ \\
\hline
\end{tabular}

$\frac{0}{\frac{0}{0}} \frac{0}{\frac{0}{0}} \frac{0}{\frac{0}{0}}$

2

$-\frac{0}{0}$

$\frac{2^{(7)}}{1^{(8)}}$

$6^{(8)}$

0

2

0

0

-

O

0

0

$\begin{array}{lll}0 & 0\end{array}$

0

$\frac{10}{5}$

10

5

$\frac{0}{0}$

(Additional information or details on survey are shown below.)

Comments

(1) Pressure in cask ranged irom $240 \mathrm{kPa}$ (gage) (0 to 35 osig).

(2) 1 of 536 truck casks designed with impact 1 imiters was received with impact limiter not installed correctly.

(3) 9 truck cask shipments had loosened tiedowns on shipment arrival. No failures of tiedorns occurred.

(4) 6 truck cask shipments had bolts which were undertorqued.

(5) Cask with bolts missing had 6 bolts total on the cask.

(6) 2 drain valves were replaced due to leakage which occurred when testing before shipment.

(7) 2 vent valves were found defective after pressure testing before shipment and were replaced.

(8) 1 truck cask pressure rel ief valve replaced after testing 6 rail cask pressure relief valves replaced due to defect with relief mechanism. 


\section{REFERENCES}

1. H. K. Elder et al; An Assessment of the Risk of Transporting Spent Nuclear Fuel by Truck. PNL-2588, Pacific Northwest Laboratory, Richland, Washington, November 1978.

2. J. W. Langhaar, "Transport Experience with Radioactive Materials." Proceedings of the International Symposium on the Management of Wastes from the LWR Fuel Cycle, CoNF-76-0701, Denver, Colorado, July 1976.

3. A. E. Grella, "A Review of Five Years Accident Experience in the U.S. Involving Nuclear Transportation (1971-1975)." International Symposium on the Design, Construction and Testing of Packaging for the Safe Transport of Radioactive Materials, IAEA-SR-10, Vienna, Austria, August 1976. 


\subsection{RELEASE SEQUENCE IDENTIFICATION}

No accidents involving spent fuel rail casks have resulted in a release of any of the package contents to man's environment. Since there is no release experience available, possible ways that releases could occur (release sequences) from rail casks must be identified through analysis of the shipping system. The information presented in Sections 5.0, 6.0 and 7.0 gives a basis for identifying events or combinations of events which could result in the release of spent fuel to the environment.

In this section a formalized procedure for identifying combinations of conditions which could result in a release is presented. The first step in the procedure is to develop fault trees using the techniques described in Section 8.1. Fault trees developed for train shipment of spent fuel are presented in Section 8.2. The second step in the procedure is to develop a list of release sequences from the fault tree. The development of these sequences is discussed in Section 8.3.

\subsection{FAULT TREE CONSTRUCTION}

The fault tree analysis technique was developed in the 1960s in the aerospace industry to identify design deficiencies before actual space flight of the equipment. Basically the procedure is to assume that a system failure occurs and work backwards to identify component failures which could cause or contribute to the failure. The fault tree failure sequences are then related to individual components for which failure data are available. In practice, fault trees seldom are developed to that degree. What occurs instead is development of fault trees in terms of basic system modules. Such a fault tree is called a Top Level Fault Tree since it usually identifies only large systems which could result in a failure. Table 8.1 shows the various fault tree symbols and their meanings and use.

The fault tree analysis applied to transportation of spent fuel involves postulation of a release of radioactive contents during transport and then examination of the series of events which must have occurred to cause the release. This form of reasoning is thought to be more inclusive than beginning 
"AND" logic gate. The simultaneous occurrence of inputs is required to cause an output.

inputs<smiles>CC(C)(C)C1CCCCCC1</smiles>

output

"OR" logic gate. The occurrence of any one of the inputs will result in an output.

inputs
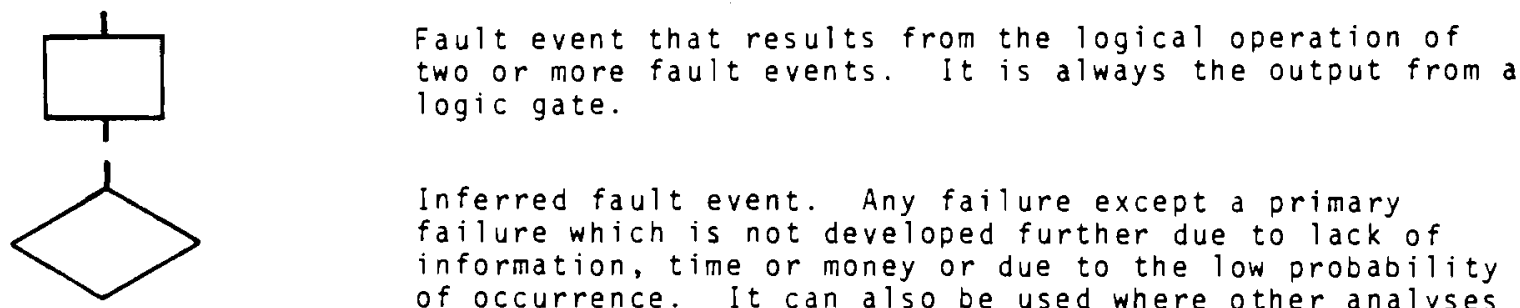

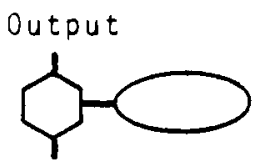

Input
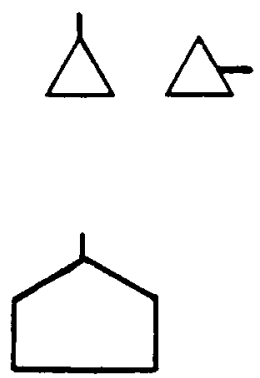

"Inibit" gate. The condition specified in the oval is required for an input fault event to result in an outout event. This condition is frequently a design linit which will not transmit a failure until the design limits have been exceeded.

Transfer symbol denoting that failure also impacts on other branches of fault tree. A line at the apex of the triangle represents a "transfer in." A line in the side represents a "transfer out." A number is placed in the triangle to identify transfer locations.

"House" defines an event that must occur, or is expected to occur, due to design and normal ooerating conditions.

with an initiating event and working toward a release, (i.e., constructing accident scenarios or decision trees). The decision tree which is developed is then broken down into all the possible release sequences. In effect, all the accident scenarios will be obtained from the fault tree. When properly applied, the accident scenarios obtained from using the fault tree methodology are likely to be more complete than the alternative method of trying to list 
all accident scenarios without the aid of any formalized reasoning process. The tree constructed using the fault tree methodology is used as the basis for estimating the total release probability.

\subsection{FAULT TREE FOR SHIPMENT OF SPENT FUEL}

The fault trees for shipments of spent fuel in the reference cask described in Appendix B are developed for rail transport in the United States. The analysis considers the combined effects of the train accident environment and packaging condition. The effects of sabotage or theft are not considered. Based on these 2 conditions, the fault tree shown in Figure 8.1 was developed to determine applicable failure sequences for the reference cask design. Pacific Northwest Laboratory's computer code ACORN ${ }^{(1)}$ was used to plot the fault tree.

For spent fuel, the barriers between the radioactive fission products in the fuel rods and man's environment were considered. All significant releases of radioactivity from the cask would have to breach both the fuel cladding and the cask. There are two other types of release sequences covered in the fault trees which could occur that do not involve breaching of both barriers. They do not result in significant release but are included in the tree for completeness of the analysis. These are: 1) release of very smal1 amount of radioactivity that could be in the cavity coolant water from small cask leaks and 2) loss of neutron shield water which could result in a direct radiation dose to individuals located close to the cask for a significant period of time. It is assumed that the public is excluded from the immediate area surrounding the cask in an accident situation.

Figure 8.1 shows the top of the fault tree. The top event on the tree is the postulated release of radioactive material to man's environment during spent fuel shipment. Radioactive releases to the environment occur through release of material from one of the main components of the cask. Detailed fault trees for the failure of various cask components are shown in Appendix E. Cask components through which releases of radioactive material could occur are: the cask head, closure seal, cask wall, pressure relief valves, drain valves and the vent valve. 


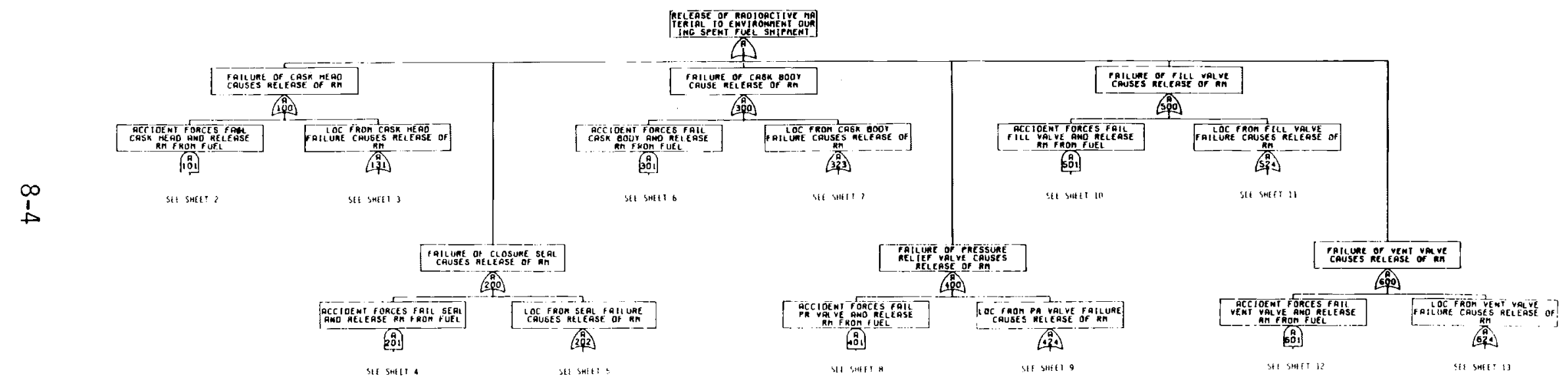

FIGURE 8.1. Spent Fuel Cask Rail Shipment Fault Tree 
Releases from the cask components occur from: 1) accident forces which cause failure of the component and release radioactive material from the fuel and 2) loss of coolant from the component failure caused by accidents or closure errors which result in release of radioactive material during transport. Both the cask component and the fuel may fail from the same accident event or they may fail from different events. Loss of cavity coolant may result from accident forces which fail one of the cask components or packaging errors which result in a loss of coolant. Loss of coolant failure sequences may result in release of radioactivity in the cavity coolant itself or coolant radioactivity plus fission products escaping from overheated fuel rods.

Each of the fault tree branches for the different cask components are then further broken down to basic events which can be assigned failure probabilities.

The list of identified events or failure elements used in the fault tree which could contribute to a release are shown in Appendix E, Table E.1. These elements are designated in the fault tree as " $X$ " with associated numerical designations and descriptive titles. Elements which have further development in the fault tree are designated by "A". The descriptive titles for the "A" elements are given in Appendix E, Table E.2.

\subsection{RELEASE SEQUENCES}

The fault tree can be thought of as a compact notation for identifying and displaying large numbers of release sequence. Computer programs are used to perform the Boolean algebra that reduces the fault tree to a series of release sequences or "cut sets". The computer code MFAULT ${ }^{(2)}$ was used for this analysis.

A listing of the release sequences identified from the transportation of spent fuel by train fault tree analysis is presented in Table 9.1 of Section 9.2. Analysis of the fault tree indicated the presence of several hundred release sequences for this particular reference cask design and transport mode. The cut sets presented in Table 9.1 survived the screening by the program MFAULT using a probability cutoff and only those which are expected to occur at least once in every $10^{15}$ shipments are presented. Duplicate cut sets are automatically 
el iminated by the computer code. To keep the amount of analysis to a reasonable level, the top cut sets or release sequences (i.e., those with the highest probability) were retained for evaluation using the probability cutoff option. The retained cut sets were then used to determine the shipping system risk. This level of analysis accounts for the significant release sequences in the fault tree.

\section{REFERENCES}

1. J. L. Carter, ACORN a Program for Plotting Fault Trees. BNIL-2144, Pacific Northwest Laboratory, Richland, Washington, October 1977.

2. P. J. Pelto, W. L. Purcell, MFAULT: A Computer Program for Analyzing Fault Trees. BNWL-2145, Pacific Northwest Laboratory, Richland, Washington, November 1977. 


\subsection{RELEASE SEQUENCE EVALUATION}

A fault tree for the rail shipment of spent fuel in the reference cask was presented in the previous chapter. From the fault tree, a set of release sequences can be identified. For example, the occurrence of the following events is one release sequence which will result in a loss of radioactive material from the cask.

\section{X2 Rail Accident Occurs}

X7 Impact Force Produced in Accident

X157 Impact Fails Normal Cask Wall and Fuel

The fault tree can be thought of as a compact notation for summarizing several thousand release sequences. As shown in Figure 9.1, based on the release sequences, both the occurrence frequency and the amount released (release fraction) must be determined for each release sequence to complete the risk evaluation. The basic data required to evaluate all release sequences are presented in this section.

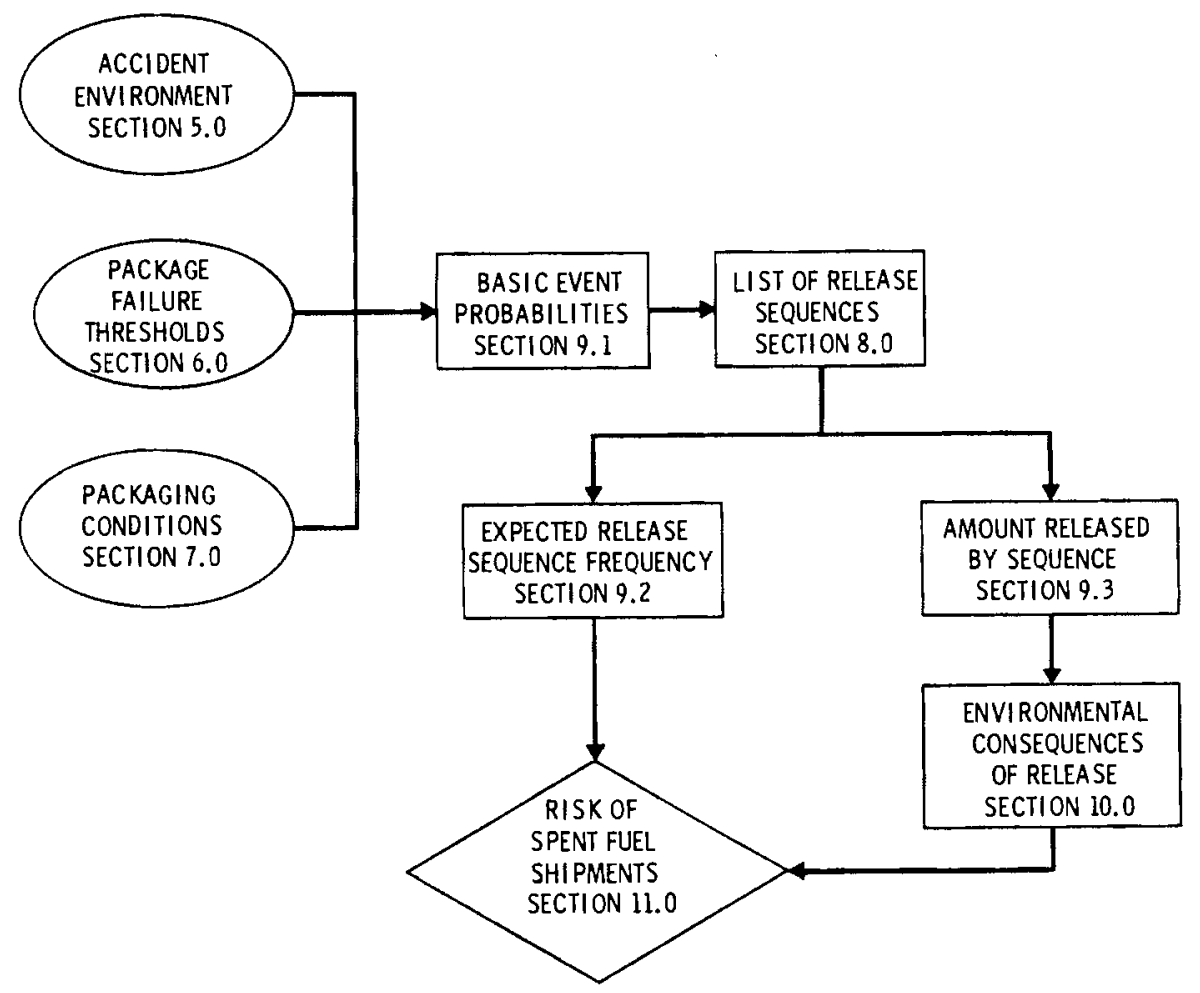

FIGURE 9.1. Remaining Steps in the Risk Evaluation 
The basic event probabilities and release fractions are fundamental to the analysis. The fault trees in Section 8 were developed to a point where data on basic events could be obtained through either analysis or survey. The estimated basic event probabilities are presented in Appendix F. The probability data are then used to develop the information on release sequence probabilities summarized in Section 9.2. Release fractions are evaluated in Section 9.3.

\subsection{BASIC EVENT PROBABILITIES}

A sequential description of failure probability estimates for spent fuel shipments in the configuration considered in this risk assessment is presented in Appendix $F$. The numbering sequence used for the components corresponds to the numbering sequence used in the fault trees shown in Figure 8.1.

The expected frequency of the release sequences identified from the fault tree is obtained by taking the product of the probabilities of each event in the sequence. In all cases the best available information was used in determining failure event probabilities.

\subsection{RELEASE SEQUENCE PROBABILITIES}

The Basic Event Probabilities in Appendix E provide the data necessary to calculate the frequency of any event sequence. As explained in Section 8.3, the computer code MFAULT ${ }^{(1)}$ was used to evaluate the release sequences. Fault tree logic and event description, failure rates, and sequence length and probability cutoff values are input to MFAULT. The code determines which sequences will actually result in releases, then eliminates those that contain more elements than the present cutoff level (10 event cut sets are the maximum allowed), and those not surviving the probability cutoff limit. Computer runs were made using different sequence lengths and probability cutoffs. It was determined that a maximum cut set length of 10 elements and a probability cutoff of $10^{-15}$ per shipment allowed all major cut sets to be identified. Redundant release sequences are eliminated automatically. The top 20 release sequences are listed in Table 9.1. 
TABLE 9.1. Top 20 Release Sequences and Probabilities for Spent Fuel by Rail Shipment

\begin{tabular}{|c|c|c|c|c|c|}
\hline $\begin{array}{l}\text { Cut } \\
\text { Set }\end{array}$ & Bas i & Eve & it Ne & mber & Probability \\
\hline 1 & 2 & 7 & 117 & 131 & $6.4 \times 10^{-7}$ \\
\hline 2 & 2 & 7 & 204 & -- & $1.2 \times 10^{-6}$ \\
\hline 3 & 2 & 7 & 205 & -- & $6.4 \times 10^{-6}$ \\
\hline 4 & 2 & 7 & 157 & -- & $1.2 \times 10^{-6}$ \\
\hline 5 & 127 & 128 & 129 & -- & $9.0 \times 10^{-8}$ \\
\hline 6 & 73 & 78 & 89 & -- & $4.5 \times 10^{-8}$ \\
\hline 7 & 2 & 7 & 153 & 166 & $3.6 \times 10^{-8}$ \\
\hline 8 & 74 & 79 & 90 & -- & $2.9 \times 10^{-8}$ \\
\hline 9 & 118 & 119 & 121 & -- & $2.9 \times 10^{-8}$ \\
\hline 10 & 2 & 7 & 254 & -- & $2.5 \times 10^{-8}$ \\
\hline 11 & 2 & 7 & 103 & -- & $2.5 \times 10^{-8}$ \\
\hline 12 & 2 & 7 & 212 & 217 & $2.5 \times 10^{-8}$ \\
\hline 13 & 2 & 7 & 66 & 85 & $2.5 \times 10^{-8}$ \\
\hline 14 & 2 & 7 & 260 & 280 & $2.5 \times 10^{-8}$ \\
\hline 15 & 2 & 7 & 117 & 132 & $2.5 \times 10^{-8}$ \\
\hline 16 & 314 & 323 & 328 & -- & $1.7 \times 10^{-8}$ \\
\hline 17 & 264 & 273 & 278 & -- & $1.6 \times 10^{-8}$ \\
\hline 18 & 2 & 7 & 60 & -- & $4.3 \times 10^{-8}$ \\
\hline 19 & 2 & 7 & 158 & -- & $4.3 \times 10^{-8}$ \\
\hline 20 & 76 & 80 & 91 & -- & $8.4 \times 10^{-8}$ \\
\hline
\end{tabular}

\subsection{RELEASE FRACTIONS}

The final step in the evaluation of release sequences is the determination of release fractions. For the purpose of this analysis, release fractions are defined as the fraction of the cask inventory that is dispersed into the atmosphere. The release sequences developed from the fault tree were divided into eight accident categories. These categories cover the spectrum of spent fue 1 transportation accidents which can result in a release of radioactive material. Release fractions were developed for each of the eight accident categories. 
The release fractions were developed from the results available in existing literature on releases from spent fuel. Published literature reported only experimental accident simulations and known chemical and physical responses of the spent fuel. No actual accidental releases during transport have occurred. $(2,3)$ Accidents are unique events and cannot be experimentally duplicated, so engineering judgment was required to arrive at realistic release estimates.

\subsubsection{Material Available for Airborne Release}

Interpretations of experimental results which provide a basis for airborne release estimates are summarized below. The basic experimental data are discussed in Appendix G. The evaluation reported here considers releases due to four chemical and mechanical mechanisms as a function of transport cask and fuel cladding conditions.

Under accident conditions postulated for this report, radioactive materials are released from the rail cask in the form of vapors, liquids or aerosols. The significant radionuclides in the spent fuel are described in Appendix H. Vapors consist of noble fission gases and elements volatilized under fire conditions. Liquid releases include cavity coolant vapors and aerosols that condense. Aerosols are released as a result of vaporizing and entraining contaminated cavity coolant or the release of fines from the fuel pellets.

The first barrier to release of the radionuclides from the fuel is the fuel cladding. To be released from the rail cask, the radioactivity must first escape the fuel rods to the cask cavity. Five mechanisms have been identified which may lead to significant release.

1. Gap Release is the energetic venting of pressurized gases from the fue 1 element plenum and pellet cladding gap. High temperature creep or mechanical forces can cause the necessary cladding rupture in a spent fuel cask. Available for release are noble gases, volatile halogens and entrained particulates which have migrated from the fuel matrix during irradiation. Information on particulate size is not available. The particulates are conservatively assumed to be less than $10 \mu \mathrm{m}$ aerosol median aerodynamic diameter (AMAD) particles of that size are biologically significant and easily transported in the atmosphere. 
2. Vaporization Release is the volatilization of low melting point fission products and their gaseous transport to and through the cask cavity. If the high temperature environment occurs before fuel cladding rupture, the venting of fuel cladding internal pressure can cause a release. For mechanical cladding ruptures followed by heating, vapor pressure and diffusion cause the release. Cesium is a primary constitutent of the semivolatile elements.

3. Leaching of fission products from the fuel pellets requires direct contact of aqueous cask cavity coolant. Contact could occur following an impact which ruptures fuel pins while the cask retains its cavity coolant. Also, undetected failed fuel (fuel which outgases in the reactor, but is not detected and overpacked in the spent fuel basin) can release a small amount of fission products to the cask under normal transport conditions. Leached radioactivity can escape from the cask with the cavity coolant.

4. Oxidation of some fraction of the $\mathrm{UO}_{2}$ fuel pellets to $\mathrm{U}_{3} \mathrm{O}_{8}$ may take place in the unlikely event of a large cask rupture. Modest-sized releases of fission products could possibly occur by this mechanism due to a large increase in surface area. The reaction proceeds at insignificant rates in a steam atmosphere. A cask breech large enough to allow flowing air to contact the fuel is necessary for this type release. Material released would be in the form of noble gases, volatilized fission products and particulates of less than $10 \mu \mathrm{m}$ AMAD.

5. Crud Release involves the release of corrosion products or crud from the surface of the fuel rods as a result of impact. In this study, the amount of crud released to the cask cavity is estimated to be about $25 \%$ of the adhered crud. The crud in the coolant that escapes the cask is then assumed to have an atmospheric release fraction of $1 \%$. For the long-cooled fuel with a dry cask, the only crud release assumed to occur would be for a large breach, which would allow some particulates to escape the cask. For a 7-fuel assembly, water-cooled cask the available inventory of ${ }^{60} \mathrm{Co}$, which is considered to be the significant nuclide, is determined using conservative data in References 4 and 5. The amount of crud assumed to be adhered to the fuel pins is $180 \mu \mathrm{Ci}$ per $\mathrm{cm}^{2}$ of fuel pin surface area. This results in about $360 \mathrm{Ci}$ of ${ }^{60} \mathrm{Co}$ present in the train cask. 


\subsubsection{Estimated Release Fractions for Various Release Categories}

The final barrier to radionuclide release is the transport cask. Very unlikely events must be postulated before a significant pathway exists through this containment. Accident combinations which were postulated in Section 8 may result in releases of radioactivity to the environment. The list of release sequences presented in Section 9.2 has been divided into eight different categories based on postulated accident conditions, and release fractions were assigned to each category.

When forces severe enough to fail the cask wall were assumed, it was conservatively postulated that all material which might escape the cladding would reach the atmosphere. ${ }^{(6)}$ On failure of a closure device, $50 \%$ retention of particulates in the cask was postulated. Examples of this type of failure would be a rupture disk venting or a valve failure.

Radioisotopes in the fuel were grouped into five different categories based on the release mechanisms from the fuel. Those categories were noble gases, iodine, cesium and ruthenium, actinides, and all other significant mixed fission products.

Tables 9.2 and 9.3 show the accident spectrum and the associated release fractions. Based on $3.2 \mathrm{MgHM}$ per spent fuel cask Table 9.4 shows estimated potential releases in curies to the atmosphere. Accidents involving a loss of cavity coolant with resultant fuel rod failure due to creep rupture result in the largest potential releases. This occurs because a pressurized creep rupture of the cladding expels much more activity than the less energetic venting following an impact type failure of the fuel.

The following paragraphs present a brief rationale for the release fractions for short-cooled fuel for each of the accidents shown in Table 9.2. Appendix $G$ presents detailed development of the release fractions. 


\section{TABLE 9.2. Accident Release Fractions to the Atmosphere from}

the Train Transport of 180-Day Cooled Spent Fuel

\begin{tabular}{|c|c|c|c|c|c|c|c|c|c|}
\hline \multirow[b]{2}{*}{ Accident Case } & \multirow[b]{2}{*}{ Cask Condrtion - } & \multirow[b]{2}{*}{ Fuel Condition } & \multirow[b]{2}{*}{$\begin{array}{l}\text { Release } \\
\text { Mechanisms }\end{array}$} & \multicolumn{6}{|c|}{ Fractional Release of Airborne Radioactivity } \\
\hline & & & & $\begin{array}{l}\text { Noble Gases } \\
\text { (Kr, Xe) }\end{array}$ & lodine ${ }^{(4)}$ & $\begin{array}{l}\text { Cesium and } \\
\text { Ruthenium }\end{array}$ & $\begin{array}{l}\text { All other } \overline{\text { Pssion }} \\
\text { Products }\end{array}$ & Actinides & $\begin{array}{l}\text { Crud Activity } \\
\text { Gócol }\end{array}$ \\
\hline $\begin{array}{l}\text { 1. Small undetected } \\
\text { leak of cavity } \\
\text { coolant }\end{array}$ & Closure error & $\begin{array}{l}\text { Some undetected } \\
\text { failed fuel }\end{array}$ & Leaching & Negligible $e^{(c)}$ & Negligible & $\operatorname{cs} 2.4 \times 10^{-8} \mathrm{C} 1 / \mathrm{hr}$ & Negligible & Negligible & Negligible \\
\hline $\begin{array}{l}\text { 2. Slow leak of } \\
\text { cavity coolant } \\
\text { due to gasket } \\
\text { failure }\end{array}$ & $\begin{array}{l}\text { Failed head or } \\
\text { value gasket. } \\
\text { leaks for four } \\
\text { hours }\end{array}$ & $\begin{array}{l}\text { Some undetected } \\
\text { failed fuel }\end{array}$ & Leaching & Negligible & Negligible & $\operatorname{cs} 2.4 \times 10^{-9}$ & Negligible & Negligible & Negligible \\
\hline $\begin{array}{l}\text { 3. Inpact and leak } \\
\text { of cavity } \\
\text { coolant }\end{array}$ & $\begin{array}{l}\text { Failed head or } \\
\text { value gasket }\end{array}$ & $\begin{array}{c}\text { All rods fail } \\
\text { on impact }\end{array}$ & $\begin{array}{l}\text { 1. Gap activity } \\
\text { 2. Leaching } \\
\text { 3. Volatilization } \\
\text { 4. Crud }\end{array}$ & 0.3 & 0.1 & $4.0 \times 10^{-8}$ & $5.0 \times 10^{-7}$ & $5.0 \times 10^{-7}$ & $3.0 \times 10^{-4}$ \\
\hline $\begin{array}{l}\text { 4. Severe cask } \\
\text { impact with a } \\
\text { rapid loss of } \\
\text { cavity coolant }\end{array}$ & $\begin{array}{l}\text { Cask failure } \\
\text { allows entry of } \\
\text { flowing air }\end{array}$ & $\begin{array}{l}\text { All rods fail } \\
\text { on impact }\end{array}$ & $\begin{array}{l}\text { 1. Gap activity } \\
\text { 2. Volatilization } \\
\text { 3. Oxidation } \\
\text { 4. Crud }\end{array}$ & 0.3 & 0.1 & $4.0 \times 10^{-4}$ & $1.5 \times 10^{-6}$ & $1.0 \times 10^{-6}$ & $2.5 \times 10^{-3}$ \\
\hline $\begin{array}{l}\text { 5. Cask involved } \\
\text { in a } 1010^{\circ} \mathrm{C} \\
\text { fire }\end{array}$ & $\begin{array}{l}\text { Cask PRV operates } \\
\text { venting coolant } \\
\text { as a jet to } \\
\text { stream }\end{array}$ & $\begin{array}{l}\text { 50: of rods fail } \\
\text { by creep } \\
\text { rupture }\end{array}$ & $\begin{array}{l}\text { 1. Gap activity } \\
\text { 2. Volatiles }\end{array}$ & 0.3 & 0.1 & $1.5 \times 10^{-4}$ & $1.0 \times 10^{-5}$ & $1.0 \times 10^{-5}$ & Negligible \\
\hline $\begin{array}{l}\text { 6. Cask impact } \\
\text { followed by a } \\
1010^{\circ} \mathrm{C} \text { fire }\end{array}$ & $\begin{array}{l}\text { 1. Cask unfailed } \\
\text { af ter impact } \\
\text { 2. PRV operates } \\
\text { venting cool- } \\
\text { ant as a jet } \\
\text { flashing to } \\
\text { steam }\end{array}$ & $\begin{array}{l}\text { Rods failed by } \\
\text { impact }\end{array}$ & $\begin{array}{l}\text { 1. Gap activity } \\
\text { 2. Volatlilzation } \\
\text { 3. Leaching } \\
\text { 4. Crud }\end{array}$ & 0.3 & 0.1 & $1.6 \times 10^{-4}$ & $2.0 \times 10^{-6}$ & $1.5 \times 10^{-6}$ & $6.2 \times 10^{-3}$ \\
\hline $\begin{array}{l}\text { 7. Severe cask } \\
\text { impact followed } \\
\text { by a 2-hr. } \\
1010^{\circ} \mathrm{C} \text { fire }\end{array}$ & $\begin{array}{l}\text { Cask fails on } \\
\text { impact allows } \\
\text { entry of } \\
\text { flowing air }\end{array}$ & $\begin{array}{l}\text { Rods failed by } \\
\text { impact }\end{array}$ & $\begin{array}{l}\text { 1. Gap activity } \\
\text { 2. Volatilization } \\
\text { 3. 0xidation } \\
\text { 4. Crud }\end{array}$ & 0.3 & 0.1 & $4.0 \times 10^{-4}$ & $1.5 \times 10^{-6}$ & $1.0 \times 10^{-6}$ & $2.5 \times 10^{-2}$ \\
\hline $\begin{array}{l}\text { 8.. Rapid loss of } \\
\text { cavity coolant } \\
\text { due to cask } \\
\text { closure device } \\
\text { failure }\end{array}$ & $\begin{array}{l}\text { Closure device } \\
\text { failed of ter } \\
\text { impact }\end{array}$ & $\begin{array}{l}50 x \text { of rods fail } \\
\text { by rieep } \\
\text { rupture }\end{array}$ & $\begin{array}{l}\text { 1. Gap activity } \\
\text { 2. Volatiles }\end{array}$ & 0.3 & 0.1 & $3.0 \times 10^{-4}$ & $1.0 \times 10^{-5}$ & $1.0 \times 10^{-5}$ & Negligible \\
\hline
\end{tabular}


TABLE 9.3. Estimated Accident Release Fractions to the Atmosphere from the Train Transport of 4-Year-Cooled Spent Fuel

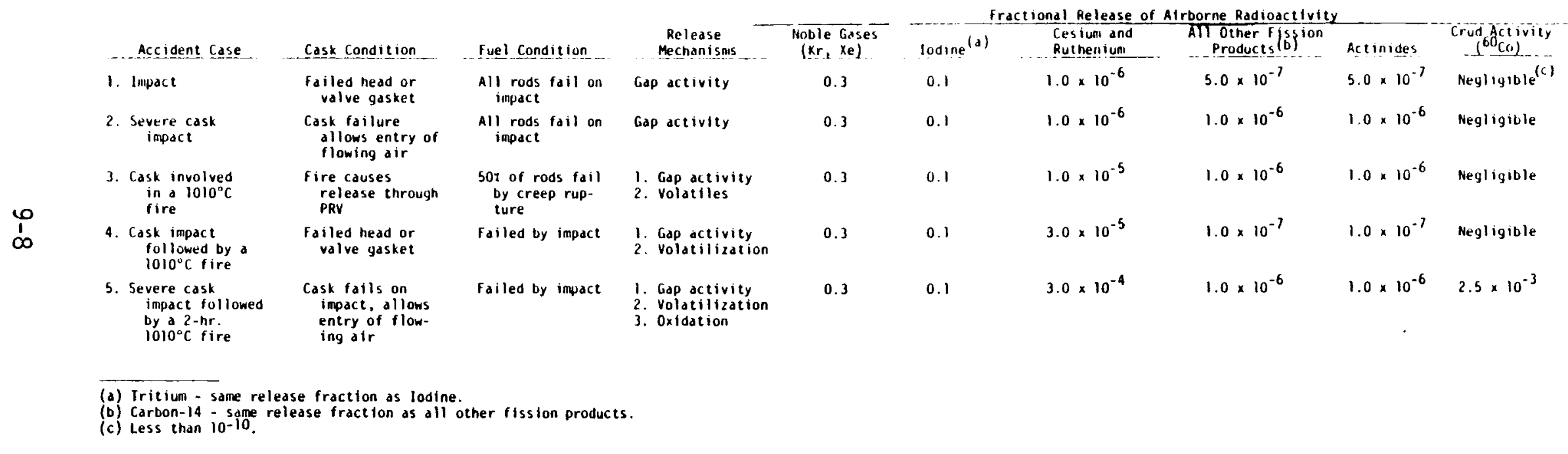


TABLE 9.4. Estimated Accidental Atmospheric Releases from the Transport of 3.22 MgHM of 180-Day Cooled Spent Fuel (Ci)

\begin{tabular}{|c|c|c|c|c|c|c|}
\hline $\begin{array}{l}\text { Accident } \\
\text { Case No (a) }\end{array}$ & $\frac{V_{0}}{\mathrm{Kr}, \mathrm{Xe}_{\mathrm{e}}}$ & $\frac{\text { tiles }}{\text { I. } 3 \mathrm{H}}$ & $\begin{array}{l}\text { Cesium } \\
\text { and } \\
\text { Ruthenium }\end{array}$ & $\begin{array}{l}\text { All Other } \\
\text { Fission } \\
\text { Products (b) }\end{array}$ & Actinides & $\begin{array}{l}\text { Crud } \\
\text { Release }\end{array}$ \\
\hline & & & & & & \\
\hline 1 & Neg. & Neg. & $2.5 \times 10^{-7}$ & Neg. & Neg. & Neg. \\
\hline 2 & Neg. & Neg. & $1.0 \times 10^{-3}$ & Neg. & Neg. & Neg. \\
\hline 3 & 1200 & $1.6 \times 10^{-3}$ & $5.0 \times 10^{-2}$ & 4.8 & 0.4 & 0.1 \\
\hline 4 & 1200 & $1.6 \times 10^{-3}$ & 380 & 14.3 & 0.8 & 0.9 \\
\hline 5 & 1200 & $1.6 \times 10^{-3}$ & 125 & 95.2 & 7.7 & Neg. \\
\hline 6 & 1200 & $1.6 \times 10^{-3}$ & 134 & 19.0 & 1.1 & 2.2 \\
\hline 7 & 1240 & $1.9 \times 10^{-3}$ & 388 & 12.3 & 0.8 & 9.0 \\
\hline 8 & 1200 & $1.6 \times 10^{-3}$ & 125 & 95.2 & 7.7 & Neg. \\
\hline
\end{tabular}

(a) From Table 9.2.

(b) $14 \mathrm{C}$ - same release as all other fission products.

1. Al1 releases involving small undetected losses of cavity coolant were assumed to have a release fraction of $1.4 \times 10^{-11}$ for Cesium. (Cesium was found to be the primary fission product in the cavity coolant from tests at Savannah River Laboratory). ${ }^{(6)}$ The release fraction was based on an assumed cavity coolant leak rate of $0.001 \mathrm{cc} / \mathrm{sec}$. It was assumed that $1 \%$ of the released activity in the coolant spilled on the ground would escape to the atmosphere as a sub-i0-um aerosol at ground level. The duration of the release was assumed to be one day. This release category results in very small releases of radioactivity which were determined not to have significant consequences. Thus, this category was not covered further in the analysis.

2. Release sequences in which a leak of cavity coolant could occur due to handling errors were assigned a release fraction of $2.4 \times 10^{-9}$ for Cesium contained in the cavity coolant. The leak was assumed to occur for eight hours until discovery and mitigation. One percent of the radioactivity escaping from the cask was assumed to be released to the atmosphere as a sub-10- $\mu \mathrm{m}$ aerosol at ground level. 
3. Failure sequences involving impact with leakage of coolant on the ground were assigned release fractions, with each of the six nuclide release categories. The release fraction values are shown in Table 9.2. This sequence releases gap radioactivity and cavity coolant. The release fractions for coolant activity are based on a time period of five hours for the release to occur following the accident before the fuel overheats. All the gap radioactivity was assumed to be released to the atmosphere. Fifty percent of the particulates are assumed to be retained in the cask. One percent of the radioactivity in the cavity coolant released was assumed to reach the atmosphere. It was conservatively assumed that the gap radioactivity was released at the time of impact at ground level. Volatilization would occur about 5 hours after loss of coolant and was assumed to last 1 to 2 hours. All volatiles released from the fuel were assumed to be released from the cask.

4. Severe impact accidents sequences which could rupture the cask and all fuel cladding were assigned release fractions for each of the six nuclide categories. This sequence can release radioactivity from all four mechanisms: gap release, vaporization, leaching, and oxidation. The gap radioactivity was conservatively assumed to be released at the time of impact along with the cavity coolant. Volatilization and oxidation releases would occur about 5 hours later and last for about 1 to 2 hours. Groundlevel release was assumed for this category of release sequences.

5. Failure sequences of a cask due to fire accidents with no impact were assigned release fractions for five nuclide release categories. No crud release is expected to occur for this case. This accident sequence involves release of gap radioactivity, coolant and volatiles. The coolant radioactivity was assumed to be released when the pressure relief valve relieves the cask pressure at about 2 hours after the fire starts. All of the coolant radioactivity was assumed to be released to the atmosphere in the fire. The gap radioactivity and volatiles were assumed to be released at 3.5 hours for a duration of about one hour. Half of the particulates were assumed to remain in the cask. Since the fire is out 
when the major part of the release occurs, ground-level release was assumed except for the coolant radioactivity which was assumed to have a release height of 100 meters.

6. A11 release sequences involving an impact followed by a fire were assigned release fractions for each nuclide release category. This sequence involves release of the gap radioactivity coolant, volatile cesium and the crud release. It was assumed that all gas gap and coolant radioactivity released at impact were airborne following the release at a height of 100 meters. The remainder of the gap radioactivity and the volatiles were assumed to be released at about 2.0 hours after the accident with a duration of about 1 to 2 hours. The delayed radioactivity was assumed to be released at ground level. For crud release, $50 \%$ is assumed to be retained in the cask and $10 \%$ of the released material is assumed to be released to the atmosphere.

7. Release sequences which involve a severe impact followed by fire were assigned release fractions for all six of the nuclide release categories. This sequence involves gap, coolant, volatile, and oxidation releases. This release is similar to category 6 except that all the gas gap release occurs at an elevated height with $100 \%$ assumed to be emitted to the atmosphere. The release height was assumed to be 100 meters. The crud release is greatest for this case since all material in the cask is assumed to be released with $10 \%$ released to the atmosphere.

8. Sequences involving loss of cavity coolant with resulting failure of the fuel were assigned release fractions for all of the fractional release categories except crud release. All of the gap radioactivity is assumed to be released due to creep rupture of the fuel pins with $50 \%$ of the particulate remaining in the cask. The release starts about 5 hours after the accident occurs and continues for about 1 hour. Since the fire is out when release occurs, ground-level release was assumed.

The following paragraphs present the rationale for the release fractions for four-year-cooled fuel for each of the accidents shown in Table 9.3. Appendix $F$ presents more detached development of the release fractions. 
1. Failure sequences involving a small impact were assigned release fractions with each of the five nuclide release categories. The release fraction values are shown in Table 9.3. This sequence releases gap radioactivity. It was conservatively assumed that the gap radioactivity was released at the time of impact at ground lever.

2. Severe impact accident sequences which rupture the cask and all fuel cladding were assigned release fractions for each of the six nuclide categories. This sequence releases radioactivity from the fuel through the mechanism of gap release. Ground-level release was assumed for this category of release sequences.

3. Failure sequences of a cask due to fire accidents with no impact were assigned release fractions for each of the six nuclide release categories. This accident sequence involves release of gap radioactivity and volatiles. The gap radioactivity and volatiles were assumed to be released at the time of fuel clad failure for each case involved for a duration of about 1 hour. Half of the particulates were assumed to remain in the cask.

4. A11 release sequences involving an impact followed by a fire were assigned release fractions for each nuclide release category. This sequence involves release of the gap radioactivity volatile cesium. It was assumed that a11 gas gap radioactivity at impact were airborne following the release at an elevation of 100 meters. The remainder of the gap radioactivity and the volatiles were assumed to be released at about 2 hours after the accident with a duration of about 1 to 2 hours. The delayed radioactivity was assumed to be released at ground lever.

5. Release sequences which involve a severe impact followed by fire were assigned release fractions for all six of the nuclide release categories. This sequence involves gap, volatile, and oxidation releases. This release is similar to category 4 except that al1 the gas gap release occurs at elevated release with $100 \%$ emitted to the atmosphere. The release height was assumed to be 100 meters. Crud release is assumed to occur in this case. Ten percent escapes the cask and 10\% of the released radioactivity is avai1able for atmospheric release in the fire. 


\section{REFERENCES}

1. P. J. Pel to and W. L. Purcel1, MFAULT: A Computer Program for Analyzing Fault Trees. BNWL-2145, Pacific Northwest Laboratory, Richland, Washington, November 1977.

2. J. W. Langhaar, "Transport Experience with Radioactive Materials,"

E. I. du Pont de Nemours \& Company, Inc., from CONF-76-0701, Ju1y. 1976.

3. A. W. Grella, A Review of Five Years Accident Experience in the U.S. Involving Nuclear Transportation (1971-1975). IAEA-SR-10/5, U.S. Department of Transportation, Washington, DC, August 1976.

4. W. E. Berry and R. B. Diegle, Survey of Corrosion Product Generation, Transport, and Deposition in Light Water Nuclear Reactors. Final Report, EPRI NP-522, TPS 76-663, Electric Power Research Institute, Palo A1to, California, March 1979.

5. G. E. Zima, Comments on Fuel Crud as a Safety and Operational Factor of Independent Spent Fuel Storage Installations (IS-FSI). PNL-2657 (NUREG/ CR-0163), Pacific Northwest Laboratory, Richland, Washington, November 1978.

6. Environmental Survey of Transportation of Radioactive Materials to and from Nuclear Power Plants. WASH-1238, U.S. Atomic Energy Commission, Washington, DC, December 1972. 


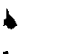




\subsection{EVALUATION OF ENVIRONMENTAL CONSEQUENCES}

In Section 9 individual release sequences were identified and evaluated by determining their expected frequency of occurrence and the corresponding release fraction. At this point, a risk number could be obtained by multiplying the individual release sequence probabilities and release fractions together, and summing overa 11 release sequences. The resulting risk number, however, would not be in a form suitable for use in comparison with other societal risks. Such a comparison is one of the objectives of the risk assessment.

To express the risk in a form suitable for use in comparison with other societal risks, conversion factors must be developed to evaluate the consequence portion of the risk number in terms of potential fatalities. The purpose of this section is to develop these conversion factors. Areas which must be evaluated in developing this information include: meteorology, demography, quantity of radioactive material made airborne and dispersed, and general population health effects. Analysis of these factors are summarized sequentialiy in separate parts of this section. The final portion of this section shows how these factors are applied to the risk number to express the risk in a form suitable for comparison with other risks.

\subsection{METEOROLOGY}

The diffusion climatology along the transport route must be incorporated into any risk analysis where the atmosphere is an important pathway for radiation dosage to man. The important atmospheric variables are: 1) wind direction indicates the initial direction of trave1,2) wind speed - indicates the rate of transport, and 3) atmospheric stability - indicates the rate of dilution and plume rise potential. Certain characteristics of release (e.g., height and temperature) are also important in the evaluation of the atmospheric pathway.

Assuming a postulated accident with a radioactivity release at the earth's surface and 1 ittle or no release-related plume rise, the immediate and greatest impact will be in the region surrounding the location of the event. Transport 
and diffusion are often determined by local influences. Wind speeds and directions show considerable variation that cannot always be summarized by large geographic regions. Local influences include topography (surface roughness, channeling), heat island effects, and proximity to large bodies of water. The inclusion of such influences in the present analysis is not possible, principally because the information is not available either from a data base or from current modeling capabilities.

For estimates of long-term diffusion averages, the average persistence of winds by sectors are used. Considering wind direction persistences alone, the actual sector annual-average air concentrations can be considerably higher or lower than an average. Based on reported values from 129 weather bureau surface stations in the conterminous U.S., the concentrations range about half to 5 times the average. Such a factor could be quite important in determining the effects of radioactivity releases near large population centers. Over a sufficiently long route the effect of the persistency of different wind directions may tend to cancel if there is a random relationship between the prevailing wind directions and population centers. The alternative of picking a route based on known diffusion climatologies to minimize risk could be beneficial; however, at the present time it is not included in the model.

The meteorological data used in this analysis are shown in Table 10.1. The values were developed from micrometeorological data collected for diffusion

TABLE 10.1. Average Wind Speed/Stability Characteristics $\mathrm{U}$
$\mathrm{m} / \mathrm{s}$
1
3
7
10
18 Wind Speed

\begin{tabular}{|c|c|c|c|c|c|c|}
\hline$U_{K}$ & & & & & & \\
\hline $\mathrm{m} / \mathrm{sec}$ & $\underline{k}$ & $k$ & $\bar{B}(j=1)$ & $D(j=2)$ & $E(j=3)$ & $\overline{\mathrm{F}}$ \\
\hline 1 & 1 & 0.255 & 0.136 & 0.202 & 0.299 & \\
\hline 3.5 & 2 & 0.508 & 0.243 & 0.274 & 0.272 & \\
\hline 7 & 3 & 0.161 & 0.190 & 0.290 & 0.339 & \\
\hline 10 & 4 & 0.052 & 0.240 & 0.312 & 0.358 & \\
\hline 18 & 5 & 0.024 & 0.276 & 0.348 & 0.356 & \\
\hline
\end{tabular}


calculations for reactor sites. Seven sets of micrometeorological data were selected from 26 compilations from reactor sites to account for the range of conditions that could reasonably occur along the route. The use of a single averaged distribution allows for the typical range of wind speeds without undue weighting to any particular site. Although this result cannot be expected to necessarily represent any particular portion of the route, it does represent the types of conditions that may be encountered on the average.

\subsection{DEMOGRAPHY}

To determine the number of people affected by a radionuclide release to man's environment resulting from a transportation accident, the population distribution along the shipping route must be characterized. This information is

needed to determine both the expected frequency at which a given population will be exposed to a release and the distribution of the resultant exposure levels within the population. These data can be developed only after the shipping routes are we11-defined and realistic population projections have been made.

The population distribution along shipping routes in this study was characterized by dividing the conterminous 48 states into four zones, based approximately on population density and degree of urbanization. The zones are shown in Figure 4.1 of Section 4. A representative state was chosen for each of the zones. Then for this study, the population data of the selected states were used in forecasting population characteristics of their respective zones.

The population densities were grouped into three classes: 1) urban for densely populated urban areas, 2) suburban for areas of moderate population density, and 3) rural for the nonurbanized areas. The suburban area data were obtained by taking the Standard Metropolitan Statistical Area (SMSA) data, which includes urban, and subtracting out the population and land area of the cities.

A set of population data for the representative states was established. Census data for 1960 were used as a data base and extended to 1970 with information available from the 1970 census. Population projections were also made to 
the year 2000 using Pickard's ${ }^{(2)}$ factors, and, using the compound interest formula to model population growth, interpolated estimates were made for 1980 , 1985 and 1990.

The fraction of each spent fuel shipment route to its storage location in each of the population zones was identified. Using this, a route population density was calculated for each route for each of the time periods considered: $1980,1990,2000$. These data were used to derive values for populations expected in 1985.

The techniques employed in each step of the analysis are described in more detail below.

\subsubsection{Population Zones Data}

The states chosen to represent the population in their respectives zones are shown below:

\begin{tabular}{|c|c|}
\hline Zone & Representative State \\
\hline I - High urbanization & New Jersey \\
\hline II - Densely populated & Massachusetts \\
\hline III - Moderately populated & Missouri \\
\hline IV - Low population & Washington \\
\hline
\end{tabular}

The population characteristics for each of the representative states based on 1960 census figures ${ }^{(3)}$ are shown in Tables 10.2 through 10.5 respestively.

In Tables 10.2 through 10.5, the city data are based on cities of 25,000 population or greater but do not include the SMSA, and the SMSA are all standard metropolitan statistical areas in the state. The rural population land area values are those of the total state minus those of the SMSA. It should be recognized that since the SMSA includes many major cities, the cities are in effect counted twice. This shows up in both the land area and total population counts, which result in the numbers adding to greater than $100 \%$. For this reason, the suburban class has been used to illustrate the projected population densities in subsequent tables. 
TABLE 10.2. New Jersey Population Characteristics-1960

\begin{tabular}{|c|c|c|c|c|c|}
\hline \multirow[b]{2}{*}{ State } & \multirow{2}{*}{$\frac{\text { Population }}{6,066,782}$} & \multirow{2}{*}{$\frac{\text { Land Area, } \mathrm{km}^{2}\left(\mathrm{mi}^{2}\right)}{19,508(7,532)}$} & \multicolumn{2}{|c|}{$\begin{array}{c}\text { Density } \\
\text { People/km² } \\
\left(\text { People/mi } / \mathrm{mi}^{2}\right) \\
\end{array}$} & \multirow{2}{*}{$\begin{array}{l}\text { Land Area, } \\
\text { Percentage } \\
100\end{array}$} \\
\hline & & & 311 & $(806)$ & \\
\hline Cities & $2,440,602$ & $585 \quad(226)^{(a)}$ & 4,170 & $(10,800)$ & 3 \\
\hline SMSA ${ }^{(b)}$ & $4,821,032$ & $10,948 \quad(4,227)$ & 443 & $(1,147)$ & 56.1 \\
\hline Rural & $1,245,750$ & $8,560(3,305)$ & 145 & (377) & 43.9 \\
\hline
\end{tabular}

(a) City of Vineland, $\mathrm{NJ}$, showed an area of $174 \mathrm{~km}^{2}\left(67 \mathrm{mi}^{2}\right)$. This was corrected to $26 \mathrm{~km}^{2}\left(10 \mathrm{mi}^{2}\right)$, which is larger than most cities of comparable population in New Jersey.

(b) Includes cities.

TABLE 10.3. Massachusetts Population Characteristics-1960

\begin{tabular}{|c|c|c|c|c|}
\hline & Population & Land Area, $\mathrm{km}^{2}\left(\mathrm{mi}^{2}\right)$ & $\begin{array}{r}\text { Density, } \\
\text { People/km } \\
(\text { People/mi }) \\
\end{array}$ & $\begin{array}{l}\text { Land Area, } \\
\text { Percentage }\end{array}$ \\
\hline State & $5,148,578$ & $20,275(7,828)$ & (657) & 100 \\
\hline Cities & $2,876,806$ & $1,847 \quad(713)$ & $1,558(4,035)$ & 9.1 \\
\hline SMSA & $4,379,477$ & $7,573(2,924)$ & $578(1,498)$ & 37.3 \\
\hline Rural & 769,101 & $12,701 \quad(4,904)$ & (157) & 62.6 \\
\hline
\end{tabular}

TABLE 10.4. Missouri Population Characteristics-1960

\begin{tabular}{|c|c|c|c|c|}
\hline & Population & Land Area, $\mathrm{km}^{2}\left(\mathrm{mi}^{2}\right)$ & $\begin{array}{c}\text { Density } \\
\text { People } / \mathrm{km}^{2} \\
\left(\text { People } / \mathrm{mi}^{2}\right) \\
\end{array}$ & $\begin{array}{l}\text { Land Area, } \\
\text { Percentage }\end{array}$ \\
\hline State & $4,319,813$ & $178,829(69,049)$ & (63) & 100 \\
\hline Cities & $1,715,093$ & $(336)$ & $1,971(5,104)$ & 0.5 \\
\hline SMSA & $3,414,071$ & $20,635 \quad(7,967)$ & (429) & 11.5 \\
\hline Rural & 905,742 & $158,195(61,079)$ & (15) & 88.5 \\
\hline
\end{tabular}

The next step was to obtain the same data for 1970 and then determine the population and land area change for major cities $(100,000$ population or greater) from 1960 to 1970 . The 1970 census data were obtained from the Statistical Abstracts of the U.S. (4) 
TABLE 10.5. Washington Population Characteristics-1960

\begin{tabular}{|c|c|c|c|c|}
\hline & Population & Land Area, $\mathrm{km}^{2}\left(\mathrm{mi}^{2}\right)$ & $\begin{array}{r}\text { Density, } \\
\text { People/km } \\
\text { (People/mi } 2 \\
\end{array}$ & $\begin{array}{l}\text { Land Area, } \\
\text { Percentage }\end{array}$ \\
\hline State & $2,853,214$ & $172,657(66,663)$ & (43) & 100 \\
\hline Cities & $1,066,336$ & $(226)$ & $1,822(4,718)$ & 0.3 \\
\hline SMSA & $1,707,136$ & $19,847 \quad(7,663)$ & (223) & 11.5 \\
\hline Rural & $1,146,078$ & $152,810(59,000)$ & (19) & 88.5 \\
\hline
\end{tabular}

The extrapolation to 2000 was then made based on information presented in an article by J. P. Pickard. (2) Pickard stated that by the year 2000 the urban 1 and area will double. He also states that $85 \%$ of the total population growth will occur in major urban areas. Using this, the total population increase is the urban increase divided by 0.85 . This leaves the rural increase at $15 \%$ of the total growth.

Based on Pickard's projections, the land areas and rural populations were calculated for the year 2000. The data for 1980 and 1990 were determined by interpolation using the compound interest formula. The resultant population characteristics for each of the four zones in the years 1980, 1990 and 2000 are presented in Table 10.6. The composite population densities for the four zones are shown in Table 10.7.

\subsubsection{Average Size of an Urban Area}

The population data summarized in Table 10.6 show that urban areas occupy a small fraction of the land area. If a radionuclide release occurs in a city, it would be incorrect to assume that the release plume is confined completely to an urban area. For that reason, it is important to determine the size of a representative urban area and thereby 1 imit the urban area included in any dose calculation. Using the representative states for each of the four zones, the average urban land area was determined. Only urban areas having a population greater than 25,000 in the year 1960 were used in the analysis. The results of this analysis are summarized in Table 10.8 for the years of interest. 
TABLE 10.6. Projected Population Density and Land Area by Zone and Population Classes

\begin{tabular}{|c|c|c|c|c|c|c|c|c|}
\hline \multirow[b]{2}{*}{$\begin{array}{c}\text { Zone and } \\
\text { Population } \\
\text { Classes } \\
\end{array}$} & \multicolumn{3}{|c|}{1980} & \multicolumn{3}{|c|}{1990} & \multicolumn{2}{|r|}{2000} \\
\hline & $\begin{array}{l}\text { Land } \\
\text { Area, } \%\end{array}$ & $\begin{array}{l}\text { Der } \\
\text { Peop } \\
\text { SPeop }\end{array}$ & $\begin{array}{l}\text { sity } \\
\text { e/km2 } \\
\left.\text { e/mi } /{ }^{2}\right) \\
\end{array}$ & $\begin{array}{l}\text { Land } \\
\text { Area, \% }\end{array}$ & $\begin{array}{r}\text { Der } \\
\text { Peop } \\
\text { Peop } \\
\end{array}$ & $\begin{array}{l}\text { lsity } \\
e / \mathrm{km}^{2} \\
\left.\mathrm{e} / \mathrm{mi} \mathrm{i}^{2}\right)\end{array}$ & $\begin{array}{l}\text { Land } \\
\text { Area, \% }\end{array}$ & $\begin{array}{c}\text { Density } \\
\text { People } / \mathrm{km}_{2} \\
\left(\text { People } / \mathrm{mi}^{2}\right) \\
\end{array}$ \\
\hline I Urban & 3.8 & 3,587 & $(9,290)$ & 4.8 & 3,239 & $(8,390)$ & 6.0 & $2,923(7,570)$ \\
\hline Suburban ${ }^{(a)}$ & 66.9 & 317 & (822) & 84.3 & 345 & (893) & 94.0 & $388(1,005)$ \\
\hline Rural & 29.3 & 236 & (612) & 10.9 & 269 & (696) & -- & -- \\
\hline II Urban & 11.5 & 1,224 & $(3,170)$ & 14.5 & 1,208 & $(3,130)$ & 18.2 & $1,089(2,820)$ \\
\hline Suburban ${ }^{(a)}$ & 35.5 & 326 & (845) & 44.8 & 294 & $(762)$ & 56.5 & (686) \\
\hline Rural & 53.0 & 92 & (238) & 40.7 & 135 & (350) & 25.3 & (635) \\
\hline III Urban & 0.8 & 1,537 & $(3,980)$ & 1.0 & 1,517 & $(3,930)$ & 1.2 & $1,502 \quad(3,890)$ \\
\hline Suburban ${ }^{(a)}$ & 17.3 & 87 & (226) & 21.8 & 86 & (223) & 27.5 & (221) \\
\hline Rural & 81.9 & 7 & (17) & 77.2 & 9 & (24) & 71.3 & (29) \\
\hline IV Urban & 0.5 & 1,695 & $(4,390)$ & 0.6 & 1,730 & $(4,480)$ & 0.8 & $1,761 \quad(4,560)$ \\
\hline Suburban ${ }^{(a)}$ & 15.0 & 51 & (131) & 18.9 & 56 & (144) & 23.7 & (147) \\
\hline Rural & 84.5 & 10 & (25) & 80.6 & 11 & (29) & 75.5 & (34) \\
\hline
\end{tabular}

(a) SMSA-Cities.

TABLE 10.7. Calculated Overal1 Average Population Densities (a)

by Zone (Persons $/ \mathrm{mi}^{2}$ )

\begin{tabular}{|c|c|c|c|}
\hline Zone & 1980 & 1990 & 2000 \\
\hline I & 1,082 & 1,231 & 1,399 \\
\hline I I & 824 & 936 & 1,061 \\
\hline I I I & 84 & 104 & 129 \\
\hline IV & 62 & 66 & 93 \\
\hline
\end{tabular}

(a) Number of figures shown is for computational accuracy and does not imply accuracy to nearest person $/ \mathrm{mi}^{2}$.

(b) $\mathrm{mi}^{2} \times 2.59=$ kilometer ${ }^{2}$. 
TABLE 10.8. Projected Land Area of Urban Areas in the Four Zones of the U.S.

\begin{tabular}{rccccc} 
& $\begin{array}{c}\text { Number of } \\
\text { Urban Areas } \\
\text { Zone }\end{array}$ & $\begin{array}{c}\text { (Pop }>25,000) \\
1960\end{array}$ & & \multicolumn{2}{c}{$\begin{array}{c}\text { Average Urban } \\
\text { Land Area, mi (2) (b) }\end{array}$} \\
I & 36 & & 1980 & $\underline{1990}$ & $\underline{2000}$ \\
II & 35 & 7.92 & 9.97 & 12.56 \\
III & 12 & 25.66 & 32.34 & 41.77 \\
IV & 8 & 43.92 & 55.33 & 69.67
\end{tabular}

(a) Only includes urban areas in representative state.

(b) $\mathrm{mi}^{2} \times 2.59=$ kilometer ${ }^{2}$.

\subsubsection{Shipping Route Mileage by Population Zones}

The second factor in the characterization of the demography is to relate the shipping routes to the population zones. Spent fuel shipment routes were previously determined in Section 4. Previous parts of Section 10.2 have characterized the population distribution for the various zones of the country for the same years. This section develops the information on the route mileage in each zone that is needed to obtain the population density along each shipping route.

A map with the population zones and the location of the reactor groups and spent fuel receiving locations (interim storage facilities and reprocessing plants expected as of 1978) is shown in Figure 4.1, Section 4. The distance between each reactor group and spent fuel receiver was calculated, and the shipping route was examined for the fraction of the route in each population zone. These data are summarized in Table 10.9.

TABLE 10.9. Shipping Route Distance by Population Zones (Fraction of Shipping Distance Within Zone)

\begin{tabular}{|c|c|c|c|c|}
\hline & Popul & tion & Zone & umber \\
\hline & $I$ & II & III & IV \\
\hline actor Group to Interim Sto & 0.09 & 0.24 & 0.57 & 0.10 \\
\hline eactor Group to Reprocessing Plant & 0.05 & 0.13 & 0.61 & 0.21 \\
\hline
\end{tabular}


The shipping routes have been completely characterized. The distance between any reactor group and the closest interim storage facility or reprocessing plant is shown in Tables A.2 and A.3, Appendix A. Population distributions in each zone along the route can be determined from the data presented in Tables 10.6 and 10.9 .

The population distribution in each zone along the route for a particular year can be determined from the data presented in Tables 10.6 and 10.9.

\subsection{POPULATION DOSE FACTORS}

Factors from the meteorological and demographic characteristics of the shipping route are combined with the dose conversion factors developed here to determine the population doses resulting from an accidental release of radionuclides to man's environment. There are two parts to the calculation. First, Dose Conversion Factors are developed to characterize the effect of inhaled radioactivity on the dose to that person and then on this health. Second, using the meteorological data, the atmospheric dispersion model described in Section 10.4 is used to characterize the radionuclide aerosol concentration downwind from the release point.

The radiation dose to an individual from inhalation of radionuclides is a function of the duration of the release, the concentration of radionuclides during the release period, the particle size, the isotopic composition of the released material, the individual's ventilation rate, the solubility of the inhaled material in body fluids, and the retention time of the radionuclide in body organs.

The dose resulting from inhalation of radioactivity is calculated using the lung model recommended by the International Commission on Radiological Protection (ICRP), TASK Group on Lung Dynamics. This model (referred to as the TGLM) characterizes the metabolic pathways of the inhaled material. (5) A computer program has been developed for calculating the dose to lung and other organs using the TGLM. ${ }^{(6)}$

The radiation dose to an individual due to inhalation of radionuclides in a passing cloud can be expressed by: 


$$
D_{j}=K^{\prime} P
$$

where:

$K^{\prime}$ is the dose conversion factor ( $\mathrm{rem} / \mathrm{Ci}$ inhaled)

$P$ is the quantity inhaled.

The quantity of material inhaled is dependent upon the time-integrated concentration of radionuclides in air as expressed by:

$$
P=b c_{a} \tau=b E
$$

where :

$b$ is human ventilation rate, $\mathrm{cm}^{3} / \mathrm{sec}$

$\mathrm{c}_{\mathrm{a}}$ is air concentration, $\mu \mathrm{Ci} / \mathrm{cm}^{3}$

$\tau$ is duration of inhalation exposure, sec

$E$ is time-integrated concentration in air, $\mu \mathrm{Ci} \mathrm{sec} / \mathrm{cm}^{3}$

The time-integrated concentration in air, $E$, is obtained from the Atmospheric Dispersion Model discussed in Section 10.4 .

Combining Equation 10-1 with Equation 10-2 and normalizing the result to the quantity of radionuclides released yields:

$$
\frac{D_{j}}{Q}=K^{\prime} b \frac{E}{Q}
$$

where:

$Q$ is the quantity released in curies

or

$$
\left(\frac{D_{j}}{Q}\right)=k\left(\frac{E}{Q}\right)
$$


where:

$K$ is the inhalation dose conversion factor $\left(K^{\prime} b\right)$ for an accidental release to the atmosphere

Inhalation dose conversion factors ( $K$ ) for 50-year dose commitments for the most significant isotopes in spent fuel are tabulated in Table 10.10. These factors are based on inhaled particles with an equivalent aerodynamic median diameter (AMAD) of 1 micrometer. Using this table, one set of conversion factors for any specified isotopic mixture can be obtained.

Table 10.11 , Parts A, B, C and D Tist the isotopic mixtures contained in the various fractional release categories outlined in Section 9 . These isotopic mixtures were used for the dose calculations reported in this document. Using the isotopic mixtures outlined, the conversion factors for the mixtures have been calculated and summarized in Table 10.12 using the TGLM conversion factors. The set of $K$ values shown in Table 10.12 convert the amount of material inhaled, expressed in total curies of the various mixtures into 50-year dose commitments to the lung and bone for both soluble and insoluble particles. The Task Group Lung Model was used in this analysis with cesium metabolized as translocation $\mathrm{Class} D$, all actinides are $\mathrm{Cl}$ ass $\mathrm{W}$, and the reference mixture of fission products as a Class $D$.

The release fractions developed in Section 9.3 are presented as fractions of the total amount of material confined in the spent fuel being carried in the shipping cask. The total amount of material released in an accident is determined from the following expression.

$$
Q=(T I A) \times A \times F_{r}
$$

where:

TIA Total Inventory Available, is the number of curies per gram in the isotopic mixture being shipped (See Table 10.11)

$Q$ is the curies released to man's environment

$A$ is the amount of material in a container in grams

$\mathrm{Fr}$ is the release fraction for the isotopes dispersed during a release. 
TABLE 10.10. Population Dose Factors for Individual Isotopes

\begin{tabular}{|c|c|c|c|c|c|}
\hline \multirow[b]{2}{*}{ Isotope } & Translocation & \multicolumn{4}{|c|}{$\begin{array}{l}\text { CONVERSION FACTOR } \\
\left(\text { rem per } \mathrm{Ci} \mathrm{sec} / \mathrm{m}^{3}\right)\end{array}$} \\
\hline & Class & Total Body & Bone & Lung & Thyroid \\
\hline${ }^{60} \mathrm{Co}$ & -- & $2.7 E+0$ & -- & $1.0 E+3$ & -- \\
\hline${ }^{85} \mathrm{Kr}$ & -- & $4.9 \mathrm{E}-4^{(a)}$ & -- & -- & -- \\
\hline${ }^{89} \mathrm{Sr}$ & $\begin{array}{l}D \\
Y\end{array}$ & $\begin{array}{l}3.4 \mathrm{E}+0 \\
9.9 \mathrm{E}-1\end{array}$ & $\begin{array}{l}3.0 \mathrm{E}+1 \\
8.5 \mathrm{E}+0\end{array}$ & $\begin{array}{l}1.1 E+0 \\
6.1 E+1\end{array}$ & $\begin{array}{l}-- \\
-\end{array}$ \\
\hline${ }^{90} \mathrm{Sr}$ & $\begin{array}{l}D \\
Y\end{array}$ & $\begin{array}{l}6.9 E+2 \\
2.8 E+2\end{array}$ & $\begin{array}{l}2.8 \mathrm{E}+3 \\
1.2 \mathrm{E}+3\end{array}$ & $\begin{array}{l}9.0 \mathrm{E}-1 \\
6.7 \mathrm{E}+0\end{array}$ & -- \\
\hline${ }^{91} \gamma$ & $\begin{array}{l}D \\
Y\end{array}$ & $\begin{array}{l}3.8 E+0 \\
4.3 E-2\end{array}$ & $\begin{array}{l}1.4 \mathrm{E}+2 \\
1.6 \mathrm{E}+0\end{array}$ & $\begin{array}{l}1.2 \mathrm{E}+0 \\
7.5 \mathrm{E}+1\end{array}$ & $\begin{array}{l}-- \\
--\end{array}$ \\
\hline${ }^{95} \mathrm{Nb}$ & $\begin{array}{l}D \\
Y\end{array}$ & $\begin{array}{l}1.9 E+0 \\
1.9 E-2\end{array}$ & $\begin{array}{l}5.2 \mathrm{E}+0 \\
5.2 \mathrm{E}-2\end{array}$ & $\begin{array}{l}5.1 \mathrm{E}-1 \\
2.1 \mathrm{E}+1\end{array}$ & $\begin{array}{l}-- \\
--\end{array}$ \\
\hline${ }^{95} \mathrm{Zr}$ & $\begin{array}{l}D \\
Y\end{array}$ & $\begin{array}{l}6.8 \mathrm{E}+0 \\
8.0 \mathrm{E}-2\end{array}$ & $\begin{array}{l}2.6 \mathrm{E}+1 \\
3.1 \mathrm{E}-1\end{array}$ & $\begin{array}{l}6.4 \mathrm{E}-1 \\
7.8 \mathrm{E}+1\end{array}$ & $\begin{array}{l}-- \\
--\end{array}$ \\
\hline${ }^{103} \mathrm{Ru}$ & $\begin{array}{l}D \\
Y\end{array}$ & $\begin{array}{l}3.0 \mathrm{E}-1 \\
1.2 \mathrm{E}-2\end{array}$ & $\begin{array}{l}6.3 \mathrm{E}-1 \\
2.5 \mathrm{E}-2\end{array}$ & $\begin{array}{l}5.2 \mathrm{E}-1 \\
2.3 \mathrm{E}+1\end{array}$ & $\begin{array}{l}-- \\
--\end{array}$ \\
\hline${ }^{106} \mathrm{Ru}$ & $\begin{array}{l}D \\
Y\end{array}$ & $\begin{array}{l}1.1 \mathrm{E}+0 \\
6.6 \mathrm{E}-2\end{array}$ & $\begin{array}{l}8.9 \mathrm{E}+0 \\
5.2 \mathrm{E}-1\end{array}$ & $\begin{array}{l}2.8 \mathrm{E}+0 \\
7.1 \mathrm{E}+2\end{array}$ & -- \\
\hline${ }^{127} \mathrm{Te}$ & $\begin{array}{l}D \\
Y\end{array}$ & $\begin{array}{l}7.5 \mathrm{E}-3 \\
1.3 \mathrm{E}-3\end{array}$ & $\begin{array}{l}3.4 \mathrm{E}-2 \\
5.8 \mathrm{E}-3\end{array}$ & $\begin{array}{l}2.1 \mathrm{E}-1 \\
3.3 \mathrm{E}-1\end{array}$ & $\begin{array}{l}7.7 \mathrm{E}+0 \\
1.3 \mathrm{E}+0\end{array}$ \\
\hline${ }^{129} \mathrm{I}$ & $\begin{array}{l}D \\
W\end{array}$ & $\begin{array}{l}1.8 \mathrm{E}+0 \\
1.8 \mathrm{E}+0\end{array}$ & $\begin{array}{l}4.3 \mathrm{E}-2 \\
4.3 \mathrm{E}-2\end{array}$ & $\begin{array}{l}1.6 \mathrm{E}-1 \\
9.9 \mathrm{E}+0\end{array}$ & $\begin{array}{l}1.4 \mathrm{E}+3 \\
1.4 \mathrm{E}+3\end{array}$ \\
\hline${ }^{131} \mathrm{I}$ & $\begin{array}{l}D \\
W\end{array}$ & $\begin{array}{l}4.7 \mathrm{E}-1 \\
3.7 \mathrm{E}-1\end{array}$ & $\begin{array}{l}\text { 5. } 1 \mathrm{E}-1 \\
4.0 \mathrm{E}-1\end{array}$ & $\begin{array}{l}5.6 \mathrm{E}-1 \\
5.4 \mathrm{E}+0\end{array}$ & $\begin{array}{l}2.6 \mathrm{E}+2 \\
2.0 \mathrm{E}+2\end{array}$ \\
\hline $131 m_{X e}$ & -- & $2.5 E-3^{(a)}$ & -- & -- & -- \\
\hline & D & $1.1 E+1$ & $6.6 \mathrm{E}+0$ & $3.2 E+0$ & -- \\
\hline${ }^{137} \mathrm{Cs}$ & D & $6.0 E+0$ & $1.1 \mathrm{E}+1$ & $2.6 \mathrm{E}+0$ & -- \\
\hline I4I $\mathrm{Ce}$ & $\begin{array}{l}W \\
Y\end{array}$ & $\begin{array}{l}1.3 \mathrm{E}-1 \\
7.0 \mathrm{E}-3\end{array}$ & $\begin{array}{l}1.6 \mathrm{E}+0 \\
8.4 \mathrm{E}-2\end{array}$ & $\begin{array}{l}8.7 E+0 \\
1.3 E+1\end{array}$ & $\begin{array}{l}-- \\
--\end{array}$ \\
\hline & $\begin{array}{l}W \\
Y\end{array}$ & $\begin{array}{l}6.4 \mathrm{E}+0 \\
6.3 \mathrm{E}-1\end{array}$ & $\begin{array}{l}1.2 E+2 \\
1.2 E+1\end{array}$ & $\begin{array}{l}1.3 \mathrm{E}+2 \\
5.6 \mathrm{E}+2\end{array}$ & -- \\
\hline & $\begin{array}{l}W \\
Y\end{array}$ & $\begin{array}{l}7.3 \mathrm{E}-1 \\
1.4 \mathrm{E}-1\end{array}$ & $\begin{array}{l}1.9 \mathrm{E}+1 \\
3.7 \mathrm{E}+0\end{array}$ & $\begin{array}{l}7.9 E+0 \\
5.4 E+1\end{array}$ & $\begin{array}{l}-- \\
--\end{array}$ \\
\hline & $\begin{array}{l}W \\
Y\end{array}$ & $\begin{array}{l}1.5 \mathrm{E}+4 \\
5.6 \mathrm{E}+3\end{array}$ & $\begin{array}{l}3.2 E+5 \\
1.2 E+5\end{array}$ & $\begin{array}{l}1.2 \mathrm{E}+4 \\
1.2 \mathrm{E}+5\end{array}$ & $\begin{array}{l}-- \\
--\end{array}$ \\
\hline
\end{tabular}


TABLE 10.10. (contd)

\begin{tabular}{|c|c|c|c|c|c|}
\hline \multirow[b]{2}{*}{ Isotope } & Translocation & \multicolumn{4}{|c|}{$\begin{array}{l}\text { CONVERSION FACTOR } \\
\left(\mathrm{rem} \text { per } \mathrm{Ci} \mathrm{sec} / \mathrm{m}^{3}\right)\end{array}$} \\
\hline & Class & Total Body & Bone & Lung & Thyroid \\
\hline${ }^{239} \mathrm{Pu}$ & $\begin{array}{l}W \\
Y\end{array}$ & $\begin{array}{l}1.7 E+4 \\
6.4 E+3\end{array}$ & $\begin{array}{l}3.6 \mathrm{E}+5 \\
1.4 \mathrm{E}+5\end{array}$ & $\begin{array}{l}1.1 \mathrm{E}+4 \\
1.1 \mathrm{E}+5\end{array}$ & $\begin{array}{l}-- \\
--\end{array}$ \\
\hline${ }^{240} \mathrm{Pu}$ & $\begin{array}{l}W \\
Y\end{array}$ & $\begin{array}{l}1.7 E+4 \\
6.4 E+3\end{array}$ & $\begin{array}{l}3.6 \mathrm{E}+5 \\
1.4 \mathrm{E}+5\end{array}$ & $\begin{array}{l}1.1 \mathrm{E}+4 \\
1.1 \mathrm{E}+5\end{array}$ & $\begin{array}{l}-- \\
--\end{array}$ \\
\hline${ }^{241} \mathrm{Am}$ & $\begin{array}{l}W \\
\gamma\end{array}$ & $\begin{array}{l}1.4 \mathrm{E}+4 \\
5.5 \mathrm{E}+3\end{array}$ & $\begin{array}{l}2.0 \mathrm{E}+5 \\
7.6 \mathrm{E}+4\end{array}$ & $\begin{array}{l}\text { 1. } 2 \mathrm{E}+4 \\
1.2 \mathrm{E}+5\end{array}$ & $\begin{array}{l}-- \\
--\end{array}$ \\
\hline${ }^{241} \mathrm{Pu}$ & $\begin{array}{l}W \\
Y\end{array}$ & $\begin{array}{l}2.7 E+2 \\
8.8 E+1\end{array}$ & $\begin{array}{l}6.6 \mathrm{E}+3 \\
2.1 \mathrm{E}+3\end{array}$ & $\begin{array}{l}3.6 \mathrm{E}+0 \\
1.9 \mathrm{E}+2\end{array}$ & $\begin{array}{l}-- \\
--\end{array}$ \\
\hline${ }^{242} \mathrm{Cm}$ & $\begin{array}{l}W \\
Y\end{array}$ & $\begin{array}{l}3.2 E+2 \\
2.4 E+1\end{array}$ & $\begin{array}{l}4.8 \mathrm{E}+3 \\
3.6 \mathrm{E}+2\end{array}$ & $\begin{array}{l}1.0 E+4 \\
3.3 E+4\end{array}$ & $\begin{array}{l}-- \\
--\end{array}$ \\
\hline${ }^{242} \mathrm{Pu}$ & $\begin{array}{l}W \\
Y\end{array}$ & $\begin{array}{l}1.6 E+4 \\
6.1 E+3\end{array}$ & $\begin{array}{l}3.4 \mathrm{E}+5 \\
1.3 \mathrm{E}+5\end{array}$ & $\begin{array}{l}1.1 \mathrm{E}+4 \\
1.1 \mathrm{E}+5\end{array}$ & -- \\
\hline & $\begin{array}{l}W \\
Y\end{array}$ & $\begin{array}{l}8.0 E+3 \\
2.7 E+3\end{array}$ & $\begin{array}{l}1.3 \mathrm{E}+5 \\
4.3 \mathrm{E}+4\end{array}$ & $\begin{array}{l}1.3 \mathrm{E}+4 \\
1.2 \mathrm{E}+5\end{array}$ & -- \\
\hline
\end{tabular}

(a) External exposure.

TABLE 10.11. Part A: Reference Mixture of Cesium Isotopes

\begin{tabular}{|c|c|c|}
\hline & $\begin{array}{l}\text { Composition } \\
\text { by Weight }(\%)\end{array}$ & $\begin{array}{c}\text { Activity } \\
\text { (Ci/g of Mix) }\end{array}$ \\
\hline${ }^{134} \mathrm{Cs}$ & 10.8 & 140.7 \\
\hline${ }^{137} \mathrm{Cs}$ & 89.2 & 77.5 \\
\hline
\end{tabular}

TABLE 10.11. Part B: Reference Mixture of Cesium and Ruthenium Isotopes

Composition Activity

by Weight (\%) $\quad(\mathrm{Ci} / \mathrm{g}$ of Mix)

$\begin{array}{lrr}{ }^{134} \mathrm{Cs} & 10.0 & 129.4 \\ { }^{137} \mathrm{Cs} & 82.0 & 71.4 \\ { }^{103} \mathrm{Ru} & 0.1 & 33.2 \\ { }^{106} \mathrm{Ru} & 7.9 & 265.6\end{array}$


TABLE 10.11. Part C: Reference Mixture of Fission Products

Composition Activity

by Weight (\%) (

$\begin{array}{rrr}{ }^{89} \mathrm{Sr} & 0.3 & 73.8 \\ { }^{90} \mathrm{Sr} & 64.6 & 91.5 \\ { }^{91} \mathrm{Y} & 0.5 & 129.9 \\ { }^{95} \mathrm{Zr} & 1.1 & 230.2 \\ { }^{95} \mathrm{Nb} & 1.1 & 442.7 \\ { }^{127 m_{\mathrm{m}}} & 0.1 & 5.6 \\ { }^{141} \mathrm{Ce} & 0.8 & 230.2 \\ { }^{144} \mathrm{Ce} & 4.0 & 126.9 \\ { }^{147} \mathrm{Pm} & 13.0 & 121.0\end{array}$

TABLE 10.11. Part D: Reference Mixture of Actinides

Composition

by Weight (\%)

${ }^{238} \mathrm{Pu}$

${ }^{239} \mathrm{Pu}$

${ }^{240} \mathrm{Pu}$

$241 \mathrm{Pu}$

${ }^{241} \mathrm{Am}$

${ }^{242} \mathrm{Cm}$

${ }^{244} \mathrm{Cm}$
1.5

59.0

25.8

12.7

0.8

0.1

0.2
Activity

$\underline{(\mathrm{C} i / g \text { of } \mathrm{Mix})}$

0.27

0.036

0.058

14.2

0.026

2.17

0.167 
TABLE 10.12. Dose Conversion Factors for Reference

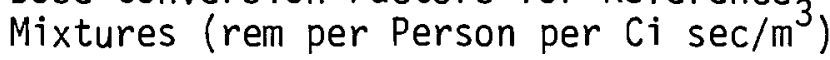

\begin{tabular}{|c|c|c|c|c|c|}
\hline Isotope & $\begin{array}{c}\text { Translocation } \\
\text { Class } \\
\end{array}$ & Total Body & Bone & Lung & Thyroid \\
\hline $\begin{array}{l}\text { Actinide } \\
\text { Isotopic } \\
\text { Mixture }\end{array}$ & W & $7.0 E+2$ & $1.5 E+4$ & $1.7 E+3$ & \\
\hline Mixed F.P. & (a) & $2.0 E+1$ & 1. $1 E+2$ & $3.2 E+1$ & $2.7 \mathrm{E}-2$ \\
\hline $\begin{array}{l}\text { Cesium - RL } \\
\text { Isotopic } \\
\text { Mixture }\end{array}$ & enium & $9.2 E+0$ & $8.2 E+0$ & $3.0 E+0$ & -- \\
\hline Cobalt - 60 & -- & $2.7 E+0$ & - & $1.0 E+3$ & -- \\
\hline
\end{tabular}

(a) These dose conversion factors were generated assuming translocation Class $\mathrm{D}$ for $\mathrm{Sr}, \mathrm{Y}, \mathrm{Zr}, \mathrm{Nb}, \mathrm{Ru}$, and Te, and Class $\mathrm{W}$ for $\mathrm{Pm}$.

\subsection{ATMOSPHERIC DISPERSION MODEL}

To affect human $1 \mathrm{ife}$, the products of a release of spent fuel must reach man via some pathway in his environment. For this study, only the air pathway was considered. Direct radiation, food chain and aquatic pathways were not considered significant pathways from releases of radioactivity in transport by rail. Although material can reach man via these pathways, the consequences from the amount of material following these pathways has been found to be insignificant when compared to the air pathway. (1) Appendix I contains further discussion on pathways of radiation exposure to man.

The radioactive releases were assumed to be neutrally buoyant when airborne. In releases involving fire, the radionuclides were assumed to be carried aloft and released from the fire plume (elevated release).

For releases of short duration, less than a day, the time-integrated air concentration at ground level is evaluated by the bivariate normal diffusion model using Pasquill diffusion parameters. (1) In equation form:

$$
E=\frac{Q}{\pi \sigma_{y} \sigma_{z} U_{h}} \exp \left[\left(-y^{2} / 2 \sigma_{y}^{2}\right)-\left(h^{2} / 2 \sigma_{z}^{2}\right)\right]
$$


where:

$E$ is ground-level time-integrated air concentration at point $x, y$, $\mathrm{Ci} \cdot \mathrm{sec} / \mathrm{m}^{3}$

$x$ is downwind distance measured from point of release, $m$

$y$ is crosswind distance measured horizontally from centerline of cloud, m

$Q$ is total release from source, curies

$\sigma_{y}$ is crosswind lateral standard deviation of cloud concentration, $m$

$\sigma_{z}$ is crosswind vertical standard deviation of cloud concentration, $m$

$\bar{U}_{h}$ is average wind speed at the height of release in direction of travel, $\mathrm{m} / \mathrm{sec}$

$h$ is height of release, $m$.

The values of $\sigma_{y}$ and $\sigma_{z}$ are a function of the downwind distance $x$ and the Pasquill Stability Category existing at the time of the accident. These values are shown in Tables 10.13 and 10.14 , respectively.

TABLE 10.13. Values of $\sigma_{y}$ for Pasquill Stability Categories

\begin{tabular}{rrrrrrrr}
$\begin{array}{r}\text { Downwind } \\
\text { Distance } \\
\text { (meters) }\end{array}$ & \multicolumn{7}{c}{$\sigma_{y}$ for Pasqui11 Type } \\
\cline { 8 - 9 } 100 & 21 & 16 & 12 & 8.0 & 6.0 & 3.9 \\
250 & 54 & 40 & 28 & 20 & 14 & 9.8 \\
500 & 100 & 76 & 55 & 37 & 28 & 18 \\
1,000 & 200 & 150 & 110 & 72 & 52 & 36 \\
2,500 & 450 & 340 & 240 & 160 & 120 & 81 \\
5,000 & 830 & 630 & 450 & 310 & 220 & 150 \\
10,000 & 1,600 & 1,200 & 850 & 570 & 410 & 280 \\
25,000 & 3,400 & 2,600 & 1,800 & 1,200 & 880 & 610 \\
50,000 & 6,200 & 4,700 & 3,400 & 2,300 & 1,600 & 1,100 \\
100,000 & 11,000 & 8,500 & 6,300 & 4,100 & 2,800 & 2,000
\end{tabular}


TABLE 10.14. Values of $\sigma_{z}$ for Pasquill Stability Categories

\begin{tabular}{|c|c|c|c|c|c|c|}
\hline \multirow{2}{*}{$\begin{array}{l}\text { Downwind } \\
\text { Distance } \\
\text { (meters) } \\
\end{array}$} & \multicolumn{6}{|c|}{$\sigma_{z}$ for Pasquill Type } \\
\hline & A & $\bar{B}$ & $\bar{C}$ & D & $E$ & $\mathrm{~F}$ \\
\hline 100 & 15 & 10 & 7.8 & 4.7 & 3.0 & 1.4 \\
\hline 250 & 43 & 26 & 18 & 10 & 7.1 & 4.0 \\
\hline 500 & 140 & 57 & 34 & 19 & 13 & 7.6 \\
\hline 1,000 & 670 & 140 & 64 & 33 & 22 & 14 \\
\hline 2,500 & 2,000 & 580 & 140 & 62 & 41 & 25 \\
\hline 5,000 & 2,000 & 2,000 & 260 & 95 & 61 & 35 \\
\hline 10,000 & 2,000 & 2,000 & 440 & 140 & 84 & 47 \\
\hline 25,000 & 2,000 & 2,000 & 880 & 220 & 120 & 64 \\
\hline 50,000 & 2,000 & 2,000 & 1,400 & 320 & 140 & 79 \\
\hline 100,000 & 2,000 & 2,000 & 2,000 & 450 & 170 & 94 \\
\hline
\end{tabular}

The dose to an individual at point $(x, y)$ can now be obtained by specifying the wind speed, height of release and the Pasquill Stability Category. For these conditions, values of $\sigma_{y}$ and $\sigma_{z}$ at the downwind distance, $x$, can be obtained from Tables 10.13 and 10.14 by interpolation. Then E/Q can be calculated at $x, y$ using Equation $10-5$ and D/Q obtained using Equation 10-3 and Table 10.12 .

The population dose could, in theory, be calculated by locating every individual or groups of individuals and going through the above procedure until all individuals receiving a dose have been included in the calculation. In practice, however, Equations 10-3 and 10-5 are used mainly to obtain the individual dose. The population dose is more easily estimated by calculating isopleths of constant dose or time-integrated air concentration. Then the area between isopleths and the mean dose received by individuals residing between the two isopleths is calculated.

The isopleth areas outside $100 \mathrm{~m}$ from the release are obtained using Equation 10-5. Rather than evaluate $E$ in Equation 10-5 for every $Q$ and every wind speed $U$, it is more convenient to move $Q$ and $U$ to the other side of the 
equation and determine isopleths of constant (UE/Q). The isopleths are determined by first selecting a value of UE/Q, obtaining values of $\sigma_{y}$ and $\sigma_{z}$ for each $x$ beginning at $100 \mathrm{~m}$, and then solving Equation 10-5 using the $k^{\text {th }}$ average wind speed (see Table 10.1) to obtain the value of $y$ for $x$. The $x, y$ coordinates for an entire isopleth of constant UE/Q can be obtained in the same way. Then by integration, the area enclosed by any isopleth can be determined. The area between two isopleths receives a dose which is intermediate between the two boundary isopleths.

Table 10.15 presents a summary of the isopleth calculations for a $1-\mathrm{m} / \mathrm{sec}$ wind speed $\left(U_{k}=U_{1}\right)$, similar tables could be constructed for other wind speeds. Isopleths were calculated for UE/Q values at order-of-magnitude intervals from $10^{-2}$ to $10^{-10}$. Areas between adjacent isopleths were calculated and are shown as the area values for each Pasquill Stability Class. The mean value of $\overline{U E / Q}$ is taken to be 2.5 times the value of UE/Q at the outer isopleth. The $n$ subscript refers to the isopleth number and the $j$ subscript denotes the stability class. A value of $j=1$ refers to $B$ stability and $j=2$ refers to $D$ stability, etc. The wind speed index, $k$, is one in the table. In Table 10.15 some of

TABLE 10.15 Land Areas Within Isopleths of a Release Plume and More Than $100 \mathrm{~m}$ from the Release Point $\left(U_{k}=U_{1}=1 \mathrm{~m} / \mathrm{sec}\right)$

\begin{tabular}{|c|c|c|c|c|c|}
\hline & \multirow{2}{*}{$(\overline{U E / Q})_{n, j, 1}$} & \multicolumn{4}{|c|}{ Pasquill Stability Classification } \\
\hline & & B & D & $E$ & F \\
\hline & $m^{-2}$ & & $A_{n, j, j}\left(\right.$ Area $\left.m^{2}\right)$ & & \\
\hline & $2.5 \times 10^{-2}$ & 0 & 0 & 0 & $4.4 \times 10^{3}$ \\
\hline & $2.5 \times 10^{-3}$ & 0 & $1.6 \times 10^{4}$ & $2.2 \times 10^{4}$ & $2.6 \times 10^{4}$ \\
\hline & $2.5 \times 10^{-4}$ & $4.1 \times 10^{4}$ & $1.4 \times 10^{5}$ & $3.8 \times 10^{5}$ & $8.0 \times 10^{5}$ \\
\hline & $2.5 \times 10^{-5}$ & $1.8 \times 10^{5}$ & $3.0 \times 10^{6}$ & $3.8 \times 10^{6}$ & $2.2 \times 10^{7}$ \\
\hline & $2.5 \times 10^{-6}$ & $1.4 \times 10^{6}$ & $7.1 \times 10^{7}$ & $1.9 \times 10^{8}$ & $2.3 \times 10^{8}$ \\
\hline & $2.5 \times 10^{-7}$ & $3.3 \times 10^{6}$ & $4.8 \times 10^{8}$ & $3.1 \times 10^{8}$ & $1.5 \times 10^{8}$ \\
\hline & $2.5 \times 10^{-8}$ & $2.8 \times 10^{6}$ & $2.9 \times 10^{8}$ & $1.7 \times 10^{8}$ & $1.1 \times 10^{8}$ \\
\hline & $2.5 \times 10^{-9}$ & $1.3 \times 10^{7}$ & $2.1 \times 10^{8}$ & $1.3 \times 10^{8}$ & $8.8 \times 10^{7}$ \\
\hline & $2.5 \times 10^{-10}$ & $6.0 \times 10^{6}$ & $1.8 \times 10^{8}$ & $1.1 \times 10^{8}$ & $7.7 \times 10^{7}$ \\
\hline
\end{tabular}


the values of $A_{n, j, 1}$ are zero. These zeros are present because the calculations indicate that for those stabilities the isopleth areas lie entirely within the 100-m evacuation distance.

It is assumed that the people residing within $100 \mathrm{~m}$ of the accident can be evacuated by transport or emergency personnel. The model assumes evacuation of all individuals within the $100-\mathrm{m}$ radius circle, who would be in the release plume, to a point where they would receive the centerline dose at $100 \mathrm{~m}$. It is felt that giving the centerline dose at $100 \mathrm{~m}$ to all evacuated individuals will more than compensate for the dose received by any individuals missed during the evacuation. Based on information available for hazardous material transport, (7) transport or emergency personnel should be capable of control1 ing entry into the $100-m$ radius circle. Outside that radius many more personnel are needed to control people who may happen onto the accident scene. Based on this model, Table 10.16 shows the area within $100 \mathrm{~m}$ which would be in an isopleth for the various stability conditions. Also shown are the values of UE/Q at the centerline $100 \mathrm{~m}$ downwind from the release point.

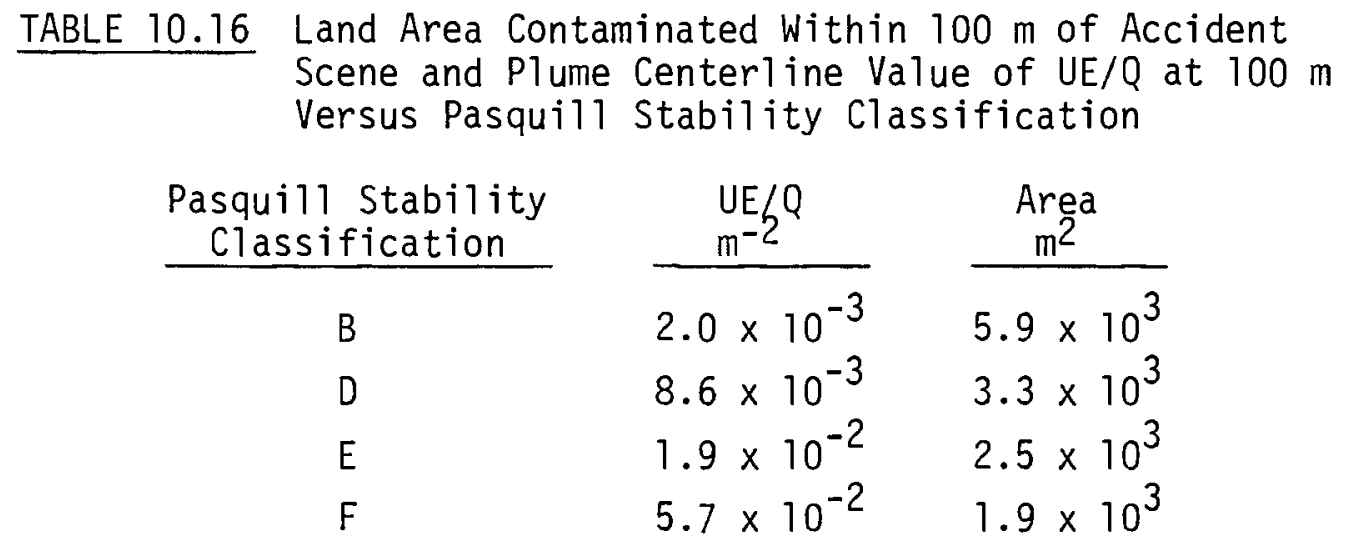

\subsection{POPULATION HEALTH EFFECTS}

The health effects that could be associated with a radioactivity release from a spent fuel cask can be divided into three categories. These are early fatalities (fatalities that occur within one year), early illnesses (people needing medical treatment), and late health effects that are estimated from 
the total population dose. In general, early effects are associated with individual total body doses of 100 rads or more and would be limited to persons in the immediate vicinity of large releases of radioactivity, such as reactor accidents covered in WASH-1400. (8) Rail-transported spent fuel casks carry relatively small amounts of radioactivity and the public is assumed to be excluded from the immediate area of an accident soon after its occurrence. On this basis potential doses to individuals would be relatively small, thus early health effects should be negligible and were not considered further for this study.

Late health effects, including latent cancer fatalities were calculated based on generally accepted values for health effects from exposure of populations from low levels of radioactivity. The effects of ionizing radiation on large populations are the only applicable data source available to regulate late health effects. The number of deaths in the U.S. population which might result from continual exposure to ionizing radiation at a rate of $0.1 \mathrm{rem} / \mathrm{yr}$ has been estimated by an advisory committee of the National Academy of Science. (9) Two risk models were used to estimate the number of excess deaths due to radiation-induced cancer. The results for each model are reported here as Tables 10.17 and 10.18. Details of the models can be found in the NAS-BEIR committee report. (9) since the analysis performed for this study was completed, a new BEIR report has been published. (10) The results of the new report are not of a magnitude to significantly change the results of this study. Therefore the calculation based on the 1972 BEIR results are retained for this report.

A range of risk estimators for the present study was determined as follows. Deaths due to "all other cancers from exposure to radiation" for all ages were assumed to range from the lower subtotal value of the "Absolute Risk Model" to the upper subtotal value of the "Relative Risk Model." As shown in Table 10.17, the resulting range is from 1,210 to 8,340 deaths per year due to all cancers other than leukemia. Based on a U.S. population of 220 million people and a dose rate of $0.1 \mathrm{rem} / \mathrm{yr}$ the range can be expressed as $6 \times 10^{-5}$ to $4 \times 10^{-4}$ in units of deaths per man-rem. 
TABLE 10.17. Estimated Numbers of Deaths per Year in the Total U.S. Population(a) Attributable to Continuous Exposure at a Rate of $0.1 \mathrm{rem} / \mathrm{yr}$, Based on Mortaljty from Leukemia and from all Other Malignancies Combined $(9)$

\begin{tabular}{|c|c|c|c|c|}
\hline \multirow[b]{2}{*}{$\begin{array}{c}\text { Irradiation } \\
\text { During Period } \\
\end{array}$} & \multicolumn{2}{|c|}{ Absolute Risk Model (a) } & \multicolumn{2}{|c|}{ Relative Risk Hodel (b) } \\
\hline & $\begin{array}{r}\text { De } \\
\text { Leukemia } \\
\end{array}$ & $\begin{array}{l}\text { ths Due to: } \\
\text { All Other Cancer }\end{array}$ & $\begin{array}{r}\text { De } \\
\text { Leukemia }\end{array}$ & $\begin{array}{l}\text { ths Due to: } \\
\text { All Other Cancer }\end{array}$ \\
\hline In Utero & 75 & 75 & 56 & 56 \\
\hline 0.9 years & 164 & $73^{7} 2^{(\mathrm{d})}$ & 93 & $\begin{array}{r}715^{(c)}(d) \\
5,869^{(d)}\end{array}$ \\
\hline $10+$ years & 277 & $\begin{array}{l}1,062(\mathrm{c}) \\
1,288\end{array}$ & 589 & $\begin{array}{l}1,665^{(\mathrm{c})} \\
2,415^{(\mathrm{d})}\end{array}$ \\
\hline Subtotal & 516 & $\begin{array}{l}1,210^{(\mathrm{c})} \\
1,485^{(\mathrm{d})}\end{array}$ & 738 & $\begin{array}{l}2,436(c) \\
8,340\end{array}$ \\
\hline Total & $\begin{array}{l}1,726 \\
2,001\end{array}$ & $\begin{array}{l}=0.6 \quad \text { increase } \\
=0.6 \text { increase }\end{array}$ & $\begin{array}{l}3,174 \\
9,078\end{array}$ & $\begin{array}{l}=1.0^{*} \text { increase } \\
=2.9 \text { increase }\end{array}$ \\
\hline
\end{tabular}

(a) Taken to be $220,000,000$ persons.

(b) The figures shown are based on the following assumptions:

- 1967 U.S. vital statistics can be used for age-specific death rates from leukemia and all other cancer and for total U.S. population.

- Values for the duration (c or d) of the latent period (the length of time after irradiation before any excess of cancer deaths occur), duration of risk ("plateau region"), and magnitude of average increase in annual mortality for each group are as shown in Table 10.18 .

(c) Thirty-year duration of plateau (see Table 10.18).

(d) Lifetime duration of plateau (see Table 10.18).

TABLE 10.18 Assumed Values Used in Calculating Estimates of Risk Shown in Table 10.17(9)

\begin{tabular}{|c|c|c|c|c|c|}
\hline \multirow[b]{2}{*}{$\begin{array}{l}\text { Age at } \\
\text { Irradiation }\end{array}$} & \multirow[b]{2}{*}{$\begin{array}{l}\text { Type of } \\
\text { Cancer }\end{array}$} & \multirow[b]{2}{*}{$\begin{array}{l}\text { Duration } \\
\text { of Latent } \\
\text { Period } \\
\text { (years) }\end{array}$} & \multirow[b]{2}{*}{$\begin{array}{l}\text { Duration } \\
\text { of Plateau } \\
\text { Region (a) } \\
\text { (years) }\end{array}$} & \multicolumn{2}{|c|}{ Risk Estimate } \\
\hline & & & & $\begin{array}{c}\text { Absolute } \\
\text { Risk (b) } \\
\text { (deaths } / 10^{6}, \\
\text { yr/rem) }\end{array}$ & $\begin{array}{l}\text { Relative } \\
\text { Risk } \\
\text { (d incr. in } \\
\text { deaths/rem) }\end{array}$ \\
\hline \multirow[t]{2}{*}{ In Utero } & Leukemia & 0 & 10 & 25 & 50 \\
\hline & $\begin{array}{l}\text { All other } \\
\text { cancer }\end{array}$ & 0 & 10 & 25 & 50 \\
\hline \multirow[t]{2}{*}{$0-9$ years } & Leukemia & 2 & 25 & 2.0 & 5.0 \\
\hline & $\begin{array}{l}\text { All other } \\
\text { cancer }\end{array}$ & 15 & $\begin{array}{l}30 \\
\text { Life }\end{array}$ & 1.0 & 2.0 \\
\hline \multirow[t]{2}{*}{$10+$ years } & Leukemia & 2 & 25 & 1.0 & 2.0 \\
\hline & $\begin{array}{l}\text { All other } \\
\text { cancer }\end{array}$ & 15 & $\begin{array}{l}30 \\
\text { Life }\end{array}$ & 5.0 & 0.2 \\
\hline
\end{tabular}

(a) Plateau region is the interval following latent period during which risk remains elevated.

(b) The absolute risk for those aged 10 or more at the time of irradiation for all cancer excluding leukemia can be broken down into the respective body sites as follows:

\begin{tabular}{lc}
\multicolumn{1}{c}{ Type of Cancer } & Deaths $/ 10^{6} / \mathrm{yr} / \mathrm{rem}$ \\
\hline Breast & 1.5 \\
Lung & 1.3 \\
GI including stomach & 1.0 \\
Bone & 0.2 \\
All other cancer & $\underline{1.0}$ \\
Total & 5.0
\end{tabular}


The fraction of cancer death by type of cancer was estimated from Table 10.18 to be:

\begin{tabular}{lc}
\multicolumn{1}{c}{ Type of Cancer } & Fraction \\
\cline { 1 - 1 } Breast & 0.30 \\
Lung & 0.26 \\
GI including stomach & 0.20 \\
Bone & 0.04 \\
All other cancer & $\underline{0.20}$ \\
Total & 1.00
\end{tabular}

These fractions of occurrence were then applied to the range of excess deaths previously derived to estimate the range of excess deaths which might occur from radionuclide releases postulated in this study. The resulting range of risk estimators are shown in Table 10.19. Values used for this study were based on the BEIR report statistics.

TABLE 10.19 Health Effects Conversion Factors, Population Dose to Maximum Number of Health Effects

\begin{tabular}{|c|c|c|}
\hline \multirow[b]{2}{*}{ Organ of Reference } & \multicolumn{2}{|c|}{$\begin{array}{c}\text { Estimated Excess Cancer Deaths } \\
\text { Per } 10^{6} \text { man-rem }(a)\end{array}$} \\
\hline & Range of Values & Value Used $(b)$ \\
\hline Lung & $16-110$ & 50 \\
\hline Thyroid & $1-15$ & 5 \\
\hline Bone & $2-17$ & 6 \\
\hline Total Body & $50-450$ & 200 \\
\hline
\end{tabular}

(a) Derived from the 1972 BEIR Report. (9)

(b) From EPA-520/4-73-002 based on 1972 BEIR statistics. (11)

It is noted that the health-effect factors listed in Table 10.19 are based on observed health effects produced at high dose levels, primarily by low linear energy transfer (LET) radiations and a hypothesis of linearity between effect and dose. It is probable that these factors are significantly dependent on the 
energy transfer (LET) of the ionizing radiation and upon the dose levels actually encountered. (12) Determination of these dependencies is not within the scope of this study.

Conversion of population doses in man-rem to estimated possible excess cancer deaths was based on the factors presented in Table 10.19. These conversion factors enable a comparison to be made of spent fuel shipment risk estimates with other societal risks.

\subsection{ESTIMATED EXPOSURE FREQUENCY}

The information presented in the previous subsections can be used as conversion factors to convert the release sequence probabilitis and release fractions developed in Section 9 to expected health effects. The remainder of this section will show how these factors are applied in the risk calculation. The risk calculation proceeds along two parallel and interrelated paths. One path characterizes the consequences of an accidental release, and the other path determines the frequency of occurrence for each event in tine consequence analysis.

As briefly discussed in Section 3, risk is expressed by the equation:

$$
R_{i}=\left(A F_{R_{i}} \times P_{R_{i}}\right) \times \sum_{q}\left(C_{E_{i, q}} \times P_{E_{q}}\right)
$$

where:

$\mathrm{q}$ represents a number of indices as indicated below.

The terms inside the first set of parentheses represent the product of the amount of material present in a shipment (A) times the fraction of that material which is lost to man's environment in the $i^{\text {th }}$ release sequence $\left(F_{R i}\right)$ times the expected frequency of occurrence of the release sequence $\left(P_{R i}\right)$. All the information needed to evaluate these terms was developed in Section 9. The two terms in the second set of parentheses represent the consequences of a unit release $(E i, q)$ and the expected frequency of encountering a given set 
of environmental conditions $\left(P_{E_{q}}\right)$. The primary purpose of previous parts of this section has been to determine the factors required to evaluate the consequences of a release. Simultaneously, the information required to determine the expected frequency that a given environmental consequence will be encountered has been presented. This part of Section 10 shows the development of the frequency of occurrence term.

The analysis presented in this section treated the wind speed, weather stability class and population class as distributed variables. The expected frequency of encountering a given set of environmental conditions can be expressed as:

$$
P_{E_{j, k, l, m}}=P_{j / k} P_{k} P_{\ell / m} P_{m}
$$

where:

$j$ is the atmospheric stability classification index

$k$ is the wind speed index

$\ell$ is the population density in zone $m$ of the U.S.

$m$ is the zone location for the shipping routes

The notation $j / k$ indicates that the expected frequency of encountering the $j$ th stability class is a function of the wind speed existing at the time of release. Similarly, the expected frequency of encountering the $l^{\text {th }}$ population density is dependent on the expected frequency that a shipment will pass through zone $\mathrm{m}$.

The values for the "P" in Equation (10-7) are obtained from the following tables in this section:

$$
\begin{aligned}
& P_{k} \text { - Table 10.1, Column } 3 \\
& P_{j / k} \text { - Table 10.1, Columns 4-7 } \\
& P_{\ell / m} \text { - Table } 10.6 \\
& P_{m} \text { - Table } 10.9
\end{aligned}
$$

By specifying a value for $j, k, l$, and $m$, one can obtain the expected frequency that an environmental condition will be experienced during a shipment. 
Associated with that frequency is a corresponding value for the environmental consequences. The relationship is best summarized by the following equation for the environmental term in the risk equation:

$\sum_{q}\left(C_{E_{i, q}} \times P_{E_{q}}\right)=\sum_{j, k, \ell, m, n} C K_{1, i} K_{2} A_{n, j, k}(\overline{E / Q})_{n, j, k} N_{\ell / m} P_{j / k} P_{k} P_{\ell / m} P_{m}$

where:

$C$ is the factor to convert grams of materials released to curies released (Table 10.11)

$\mathrm{K}_{1, i}$ converts curies received by man to specific organ dose (Table 10.12) for isotope groupings

$K_{2}$ converts organ dose to health effects (Table 10.19)

$A_{n, j, k}$ is the area between two isopleths $n$ and $n-1$ (Tables 10.15 and 10.16)

$(\overline{E / Q})_{n, j, k}$ is the time integrated air concentration received in $A_{n, j, k}$ per curie released

$\bar{E} / Q=\overline{U E} / Q(T a b l e s \quad 10.15$ and 10.16) divided by $\bar{U}$ (Table 10.1)

$\mathrm{N}_{\ell / \mathrm{m}}$ is the population density in the plume of released radionuclides (Table 10.6)

The subscripts and the values for $P$ in Equation 10-8 have been defined following Equation 10-7. The product $\left(C_{E_{j, q}} \times P_{E_{q}}\right)$ has units of fatalities per gram of material released. If several organs receive a dose as a result of a release, then the sum of products $k_{1, i} k_{2}$ for each organ receiving a dose must be summed to get the overall effect to the individual.

Equation 10-8 summarizes the information presented in this section. In Section 11 , these results are used in conjunction with the release sequences developed in Section 9 to obtain the risk of shipping spent fuel by train in the United States. 


\section{REFERENCES}

1. David H. Slade, Ed., Meteorology and Atomic Energy, 1968. TID 24190, Office of Information Services, U.S. Atomic Energy Commission, Washington DC, 1968.

2. J. P. Pickard, Urban Land and New Trends in Land Development. Dept. of Housing and Urban Development, January 1970.

3. County and City Data Book 1967. U.S. Dept. of Commerce, 1968.

4. Statistical Abstracts of the U.S. 1970. Census Division, U.S. Dept. of Commerce, Washington DC, 1971.

5. The Metabolism of Compounds of Plutonium and Other Actinides. A report prepared by a Task Group of Committee II of the International Commission on Radiological Protection, ICRP Publication 19, Pergamon Press, May 1972.

6. J. Houston, D. L. Strenge, and E. C. Watson, DACRIN Computer Program for Calculations of Organ Dose from Acute or Chronic Radionuclide Inhalation. BNWL-B-389, Pacific Northwest Laboratory, Richland, Washington, December 1974. (Reissued Apri1 1976)

7. Highway Accident Report - Automobile-Truck Collision Followed by Fire and Explosion of Dynamite Cargo on U.S. Highway 78, near Waco, Georgia, on June 4, 1971. NTSB-HAR-72-5, National Transportation Safety Board, Washington, DC, September 21, 1972.

8. Reactor Safety Study - An Assessment of the Accident Risks in the U.S. Commercial Nuclear Power Plants. WASH-1400 (NUREG-75/014), U.S. Nuclear Regulatory Commission, Washington DC, October 1975.

9. The Effects on Populations of Exposure to Low Levels of Ionizing Radiation. Report of the Advisory Committee on the Biological Effects of Ionizing Radiations, National Academy of Science, Washington, DC, November 1972.

10. The Effects on Populations of Exposure to Low Levels of Ionizing Radiation. Committee on the Biological Effects of Ionizing Radiation, National Research Council, National Academy Press, Washington, DC, 1980.

11. Environmental Radiation Dose Commitment: An Application to the Nuclear Power Industry. EPA-520/4-73-002, U.S. Environmental Protection Agency, Washington DC, June 1974.

12. National Council on Radiation Protection and Measurements, Review of the Current State of Radiation Protection Philosophy. NCRP Report No. 43, Washington DC, January 15, 1975. 


\subsection{THE RISK OF SHIPPING SPENT FUEL BY TRAIN}

In this section, the risk of shipping spent fuel by train is presented and discussed. The risk is calculated using the general methodology presented in Section 3 with the computer code TRECII. (1) TRECII is a risk calculating computer code developed at PNL for transportation risk analysis. The probability of an accidental release occurring during transport was determined in Section 9, and the consequences of such a release were discussed in Section 10. Section 11.1 presents the risk of shipping spent fuel in the reference year, based on the shipping system model given in Section 4. Major contributors to the overall risk are discussed in Section 11.2 and the results of sensitivity studies are presented in Section 11.3.

\subsection{RISK EVALUATIONS FOR SPENT FUEL SHIPMENTS}

Section 11.1.1 presents a development of the risk equations on which the TRECII code is based and a discussion of measures of risk. The annual risk from the shipment of spent fuel for two shipping scenarios, the "once through" fuel cycle and fuel reprocessing, are given in Section 11.1.2.

11.1.1 The Risk Equation

As described in Section 3, the total risk is defined as:

$$
R=\sum_{i} R_{i}
$$

where:

$$
R_{i}=\left(A F_{R_{i}} \times P_{R_{i}}\right) \times \sum_{q}\left(C_{E_{i, q}} \times P_{E_{q}}\right)
$$

The subscript " $i$ " refers to the $i$ th sequence that results in a radionuclide release. Equation 10-8 gives a general expression for the terms in the second set of parenthesis in Equation (11-2). Substituting this expression into Equation (11-2) results in the following equation. 
$R_{i}=\left(A F_{R_{i}} \times P_{R_{j}}\right) \sum_{j, k, \ell, m, n} C K_{1, j} K_{2} A_{n, j, k} \overline{(E / Q)} n, j, k N_{\ell / m} P_{j / k} P_{k} P_{\ell / m} P_{m}$

The total risk of shipping spent fuel then becomes:

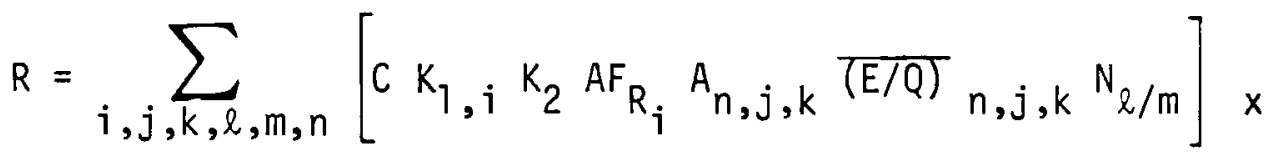

$$
\begin{aligned}
& {\left[\begin{array}{lllll}
P_{R_{i}} & P_{j / k} & P_{k} & P_{\ell / m} & P_{m}
\end{array}\right]}
\end{aligned}
$$

Equation (11-4) has been arranged so that the frequency of occurrence terms are separated from the consequence terms.

In Equation (11-4) the frequencies of occurrence and the consequences of all accidents are summed to obtain a single annual risk number. This number can be thought of as the expected frequency of occurrence of a fatality attributable to spent fuel transport. As discussed in Section 1, the risk spectrum should a]so be considered because it differentiates between an event which occurs once a year and results in one fatality and an event which occurs once in a thousand years but results in 1,000 fatalities. In order to distinguish between these two events which have the same risk but different severities, curves are constructed which plot accident severity versus the expected frequency of accidents with equal or greater severity. The two events described above have discrete contributions to the graph. Thus for the risk of two operations to be truly comparable, they must have both the same risk and the same spectrum of probabilities and consequences.

Both the risk and the risk spectrum can be obtained from the terms in Equation (11-4). The number of fatalities from an accident release sequence is expressed by the term inside the first set of brackets in Equation (11-4). The frequency of the consequence (i.e., number of fatalities) is obtained by calculating the terms within the second set of brackets. These two terms can be thought of as pairs of numbers. The risk spectrum curves can be obtained by choosing a value for $N$, the number of fatalities, and then scanning the paired 
sets of numbers for any first terms which equal or exceed $N$. The summation of all second terms which have a first term greater than or equal to $N$ is the expected frequency of occurrence of accidents which result in $N$ or more fatalities. This is one point on the risk spectrum curve. This operation is continued until points on the risk spectrum curve are calculated for selected values of $N$ down to one fatality.

\subsubsection{The Risk of Shipping Spent Fuel for the Reference Shipping System}

A summary of the shipping system details given in Section 4 and Appendix A, which are used in the analys is of spent fuel shipments, is shown in Table 11.1. The estimated risk involved with shipping spent fuel is based on this information. Accidents involving train shipments of spent fuel could be expected to occur at a rate of $6.2 \times 10^{-6}$ per railcar $\mathrm{km}$ or about once in $160,000 \mathrm{~km}$. At these frequencies a train accident occurs in every 175 shipments to interim storage facilities and 1 in 155 shipments to reprocessing Plants. At these values

\section{TABLE 11.1. Shipping Characteristics for Spent Fuel by Train}

\begin{tabular}{|c|c|c|c|}
\hline & & $\begin{array}{l}\text { Once-Through } \\
\text { Fuel Cycle } \\
\end{array}$ & $\begin{array}{c}\text { Spent Fuel } \\
\text { Reprocessing }\end{array}$ \\
\hline $\begin{array}{l}\text { Amount spent fuel } \\
\text { per shipment (MgHM) }\end{array}$ & $\begin{array}{l}\text { PWR } \\
\text { BWR }\end{array}$ & $\begin{array}{l}3.227 \\
3.546\end{array}$ & $\begin{array}{l}3.227 \\
3.546\end{array}$ \\
\hline $\begin{array}{l}\text { Shipment } \\
\text { origin/destination }\end{array}$ & & $\begin{array}{l}\text { Reactor/ } \\
\text { Interim } \\
\text { storage }\end{array}$ & $\begin{array}{l}\text { Reactor/ } \\
\text { Reproces- } \\
\text { sing plant }\end{array}$ \\
\hline $\begin{array}{l}\text { Material shipped } \\
\text { per year (MgHM) }\end{array}$ & & 1,474 & 1,474 \\
\hline $\begin{array}{l}\text { Number of shipments }(a) \\
\text { per year by train }\end{array}$ & & 471 & 471 \\
\hline $\begin{array}{l}\text { Average shipment } \\
\text { distance }(\mathrm{km})\end{array}$ & & 912 & 1,020 \\
\hline $\begin{array}{l}\text { Accident probability }(\mathrm{c}) \\
\text { number } / \mathrm{km}\end{array}$ & & $6.2 \times 10^{-6}$ & $6.2 \times 10^{-6}$ \\
\hline
\end{tabular}

(a) Number of shipments determined in Appendix A.

(b) Shipment distances determined in Appendix A.

(c) Reference 2. 
a train accident involving spent fuel might be expected to occur about once every 0.4 years for shipments to interim storage and 0.33 years for shipments to reprocessing plants.

Based on the release sequence probabilities determined in Section 9, the analysis shows that 1 out of $2.8 \times 10^{4}$ spent fuel shipments to interim storage is estimated to result in the release of a small amount of radioactive material. An example of this type of release is a small leak of cavity coolant which would not result in any consequence to the general public. The probability of a release resulting in one or more fatalities due to one year's shipment of 180-day cooled spent fuel to interim storage facilities by train is estimated to be $5.5 \times 10^{-5}$ or about once in every 18,000 years. For 4-year-cooled fuel the probability of a release resulting in one or more fatalities is estimated to be $8.3 \times 10^{-7}$ which is about a $98.5 \%$ reduction in the risk level. For spent fuel shipped to reprocessing plants, the probability of a release resulting in one or more deaths per year is estimated to be $3.5 \times 10^{-5}$. These results are summarized in Table 11.2.

TABLE 11.2. Summary of Risk of Transporting Spent Fuel by Train

\begin{tabular}{|c|c|c|}
\hline $\begin{array}{l}\text { Once } \\
\text { Fue }\end{array}$ & $\begin{array}{l}\text { hrough } \\
\text { Cycle }\end{array}$ & \\
\hline $\begin{array}{c}\text { 180-day- } \\
\text { Cooled Fuel }\end{array}$ & $\begin{array}{c}\text { 4-year- } \\
\text { Cooled Fuel }\end{array}$ & $\begin{array}{l}\text { Spent Fuel } \\
\text { Reprocessing }\end{array}$ \\
\hline
\end{tabular}

Probability of accident (events/year)

Probability of a radioactive (a) release (events/year)

Probability of release resulting in one or more fatalities (events/year)
2.6

$1.7 \times 10^{-2}$

2.6

4.9

(a) A release which has no measurable consequence to the general public.

(b) 180-day cooling time assumed for reprocessing.

The risk spectrum curves for shipment of spent fuel to interim storage are shown in Figure 11.1. Also shown in the figure are the risk spectra for meteorites, dam failures, persons on the ground killed from air crashes, the total of all natural events and the total of all man-caused events. These curves were taken from Reference 2. 


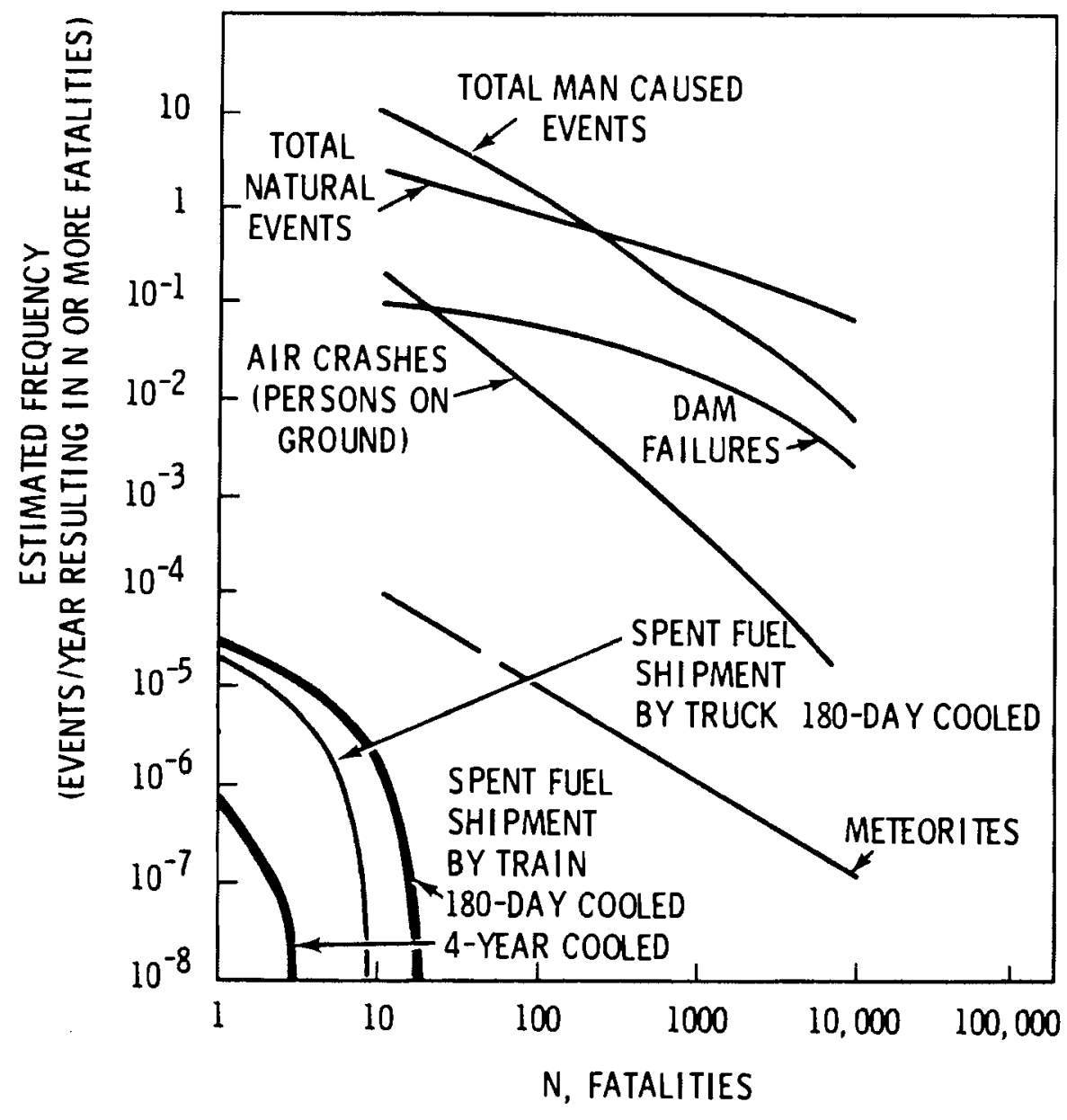

FIGURE 11.1. Risk Spectrum for Shipment of Spent Fuel to Interim Storage and Other Risk Spectra

The total risk due to the radiation exposure from the shipment activities expected about the mid-to-late 1980s from the train shipment of spent fuel is $1.3 \times 10^{-4}$ fatalities per year. Using the estimated U.S. population at risk ( 40 million) for spent fuel shipment, the individual risk per year is about $9.4 \times 10^{-9}$ fatalities per person. The total risk from train accidents involving spent fuel is compared to the risk from truck shipments and other kinds of accidents and natural disasters in Table 11.3.

Figure 11.2 shows the risk spectrum from spent fuel shipments to both interim storage and reprocessing plants for 180-day cooled fuel. The risk for shipment to reprocessing plants is slightly less than that for shipping to interim storage. The calculated difference of about $15 \%$ is due to the 
TABLE 11.3. Average Total and Individual Risk from Various Accidents and Natural Disasters

\begin{tabular}{|c|c|c|}
\hline Event & $\begin{array}{c}\text { Total Risk } \\
\text { (Fatalities/year) } \\
\text { (a) }\end{array}$ & $\begin{array}{l}\text { Individual Risk, } \\
\text { Per Year, Per } \\
\text { No. of Persons }\end{array}$ \\
\hline All accidents & 103,030 & 1 in 2,000 \\
\hline $\begin{array}{l}\text { Motor vehicle } \\
\text { accidents }\end{array}$ & 46,700 & 1 in 4,000 \\
\hline Air crashes (passengers) & 1,552 & 1 in 130,000 \\
\hline Dam failures & $35^{(c)}$ & 1 in $5,700,000$ \\
\hline $\begin{array}{l}\text { Air crashes (persons on } \\
\text { ground) }\end{array}$ & $\sigma^{(d)}$ & 1 in $33,000,000^{(e)}$ \\
\hline Meteorites & $1.0 \times 10^{-3(f)}$ & 1 in $2 \times 10^{11}$ \\
\hline $\begin{array}{l}\text { Spent fue } 1 \text { truck shipments } \\
\text { 180-day cooled (excess } \\
\text { cancer fatalities) }\end{array}$ & $4.5 \times 10^{-5}$ & 1 in $6 \times 10^{11(e)}$ \\
\hline $\begin{array}{l}\text { Spent fuel train shipments, } \\
\text { 180-day cooled (excess } \\
\text { cancer fatalities) }\end{array}$ & $1.3 \times 10^{-4}$ & 1 in $1.1 \times 10^{11(e)}$ \\
\hline
\end{tabular}

(a) Based on 1975 statistics unless otherwise noted.

(b) Based on total U.S. population of 22 a million.

(c) Average for dam failures 1889-1972.

(d) Average for years 1960-1973. (2)

(e) Based on population at risk not the entire U.S. population (see Reference 2).

(f) From Reference 2.

different shipping routes for the two scenarios. Although the average shipment distance for shipping to reprocessing plants is longer, the difference in population distributions along the shipping routes accounts for the lower risk.

The risk of shipping spent fuel is well below the risk for man-caused events. The spent fuel shipment risks are also well below natural occurring risks such as the risk of fatality from being struck by a meteorite. The results of this study indicate that the risk of shipping spent fuel by train is slightly higher than the risk of shipping spent fuel by truck. Although 


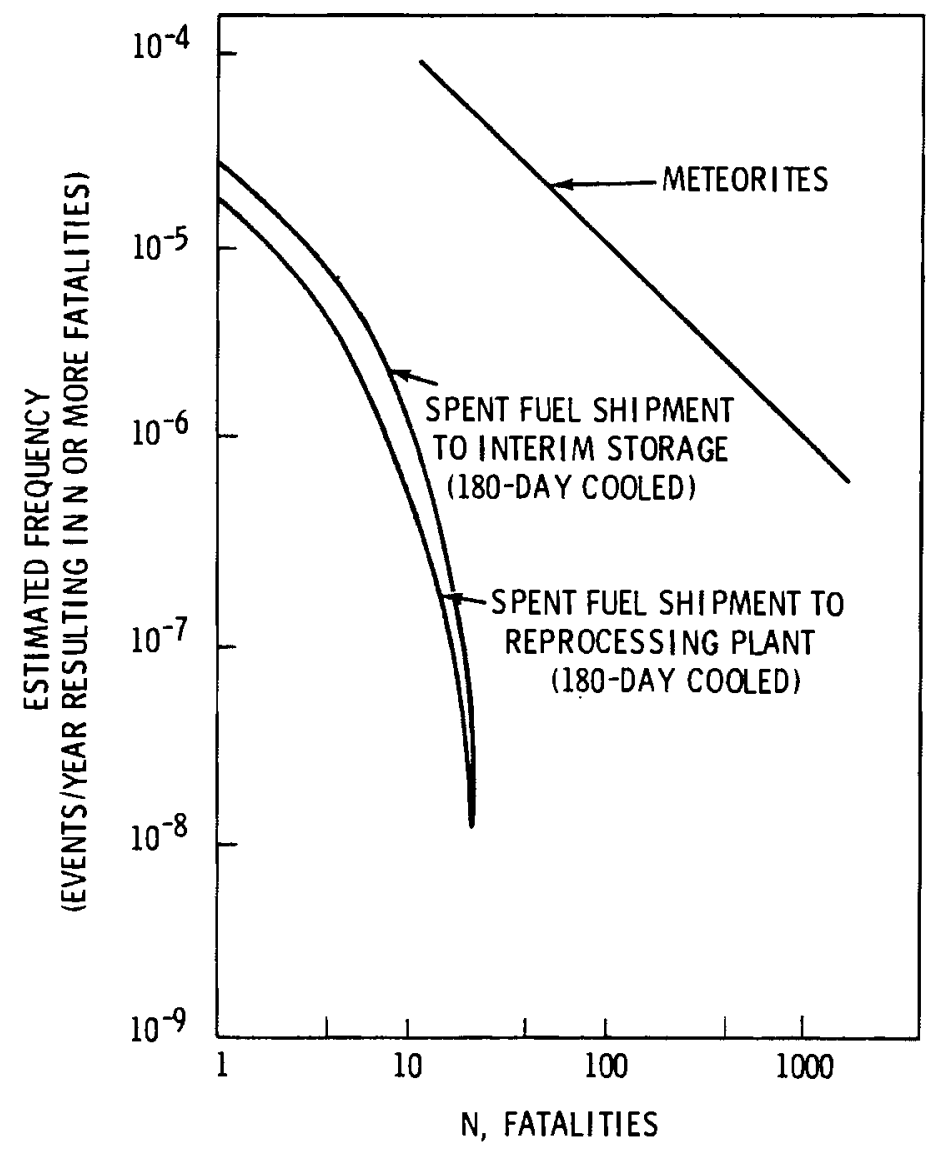

FIGURE 11.2. Risk Spectra for Train Spent Fuel Shipments Expected about Mid-to-Late 1980s

the risk of shipping spent fuel by train per MgHM is slightly less than that for truck shipment, the larger amount of fuel shipped by rail results in slightly higher total risk.

The risk values derived in this study are believed to represent a conservative upper limit because of the assumptions used in the analysis. These assumptions include:

- conservative accident environment data

- conservative release fractions

- no corrective action taken in loss of cavity cooling situations. 
The risks from spent fuel shipment by train are significantly. smaller than many man-caused and natural risks to which society and individuals are exposed. Society commonly accepts risks which represent a hazard one or more orders of magnitude greater than the shipment of spent fuel. It should be noted that the spectra for other societal risks include both latent (long-term) and acute (short-term) fatalities, whereas there are no acute fatalities related to the radiological consquences of shipping spent fuel.

\subsection{RISK SENSITIVITY STUDIES}

Before analyzing the sensitivity of the risk evaluation to the value of certain system parameters, it is important to note a fundamental sensitivity of the risk evaluation. The calculated risk is a function of the shipping assumptions. Use of different shipping routes, different containers, changes in the predicted industry practices, etc., would result in a different risk. In general, reevaluation of the risk would be required for these changed conditions.

Risk sensitivity evaluations permit analysis of the importance of the various factors that contribute to the risk. They can be used to identify and quantify the effects of the major contributors to the risk and study the effects of possible design or regulatory changes on the risk. Most sensitivity studies are performed by repeating the risk calculation with a changed value for the parameter of interest. In general, the dependence of the risk on a particular parameter is complex. In some cases, however, the parameter enters simply and directly into the risk calculation and the sensitivity can be determined directly.

The results of the risk sensitivity studies for the train shipment of spent fuel in the reference cask are presented in Table 11.4. In the base case, failure of the cask and components by impact force were calculated to contribute to about $84 \%$ of all radioactivity releases. Failure due to fire was calculated to contribute to only about $5 \%$ of all releases and accidents that occur when packaging deficiencies are present are calculated to contribute to about $11 \%$ of the releases. 
TABLE 11.4. Risk Sensitivity Cases for Spent Fuel Shipments

Expected in the U.S. about Mid-to-Late 1980s

\begin{tabular}{|c|c|c|}
\hline $\begin{array}{l}\text { Description of } \\
\text { Sensitivity Case } \\
\end{array}$ & $\begin{array}{c}\text { Risk Leve1 } \\
\text { (Estimated Annual } \\
\text { Frequency of Occurrence } \\
\text { of One or More Fatalities) } \\
\end{array}$ & $\begin{array}{l}\text { Risk Leve1 } \\
\text { Relative to } \\
\text { Base Case } \\
\end{array}$ \\
\hline $\begin{array}{l}\text { Base case }{ }^{(a)}(180-\text { day } \\
\text { cooled fuel) }\end{array}$ & $5.5 \times 10^{-5}$ & -- \\
\hline $\begin{array}{l}\text { Corrective action to } \\
\text { provide cask cooling }\end{array}$ & $2.2 \times 10^{-5}$ & 0.40 \\
\hline $\begin{array}{l}\text { Increased impact } \\
\text { failure threshold } \\
\text { (20\% more energy required } \\
\text { for failure) }\end{array}$ & $3.3 \times 10^{-5}$ & 0.60 \\
\hline $\begin{array}{l}\text { Zero packaging } \\
\text { condition deficiencies }\end{array}$ & $5.2 \times 10^{-5}$ & 0.95 \\
\hline $\begin{array}{c}\text { A11 release fractions } \\
\text { times factor of } 10\end{array}$ & $3.8 \times 10^{-4}$ & 7.0 \\
\hline
\end{tabular}

(a) Shipment case described in Section 11.1.2.

The sensitivity of the risk to impact failure threshold forces was determined by assuming that the cask could absorb more impact energy before failing, thus increasing the failure threshold velocities. A $40 \%$ reduction in risk leve 1 is calculated to result by assuming that $20 \%$ more impact energy could be absorbed by the cask. Since the failure thresholds are conservatively calculated, the calculated risk values for the base case are believed to represent a conservative upper limit.

A sensitivity study performed to determine the effects of packaging errors on the risk. The case is evaluated assuming no packaging errors are present during the shipment. A $11 \%$ reduction in risk leve1 is estimated to occur, indicating that packaging deficiencies are of concern but not a controlling factor.

It is assumed in the base case that no corrective action by transport or emergency personnel could be taken at an accident scene to replace cavity coolant that was lost. This corrective action could reduce the risk by preventing 
fuel overheating and subsequent fuel clad failure. Sensitivity analysis showed a $60 \%$ reduction in risk level if corrective action could be taken to provide cask cooling within two hours of the accident. To assure that corrective action could be taken if an accident occurred would entail that trained emergency personnel be available at the accident scene within two hours.

To illustrate the sensitivity of the risk to the radionuclide release fractions used in the base case, it is assumed that all release fractions are increased by a factor of 10 , but not exceeding a maximum value of one. This case is believed to represent an extreme upper-limit example, since the release fractions developed in Section 9 are believed to be conservative. Increasing all the release fractions by a factor of 10 makes them very conservative. It is seen from the sensitivity analysis that this increases the risk by a factor of about seven. Conservative extensions of existing data on the fractions of radioactivity released under simulated extreme accident conditions could increase the certainty of the risk evaluation.

1. A. L. Franklin, TRECII: A Computer Program for Transportation Risk Assessment. PNL-3208, Pacific Northwest Laboratory, Richland, Washington, May 1980.

2. Reactor Safety Study - An Assessment of the Accident Risks in the U.S. Commercial Nuclear Power Plants. WASH-1400 (NUREG-75/014), U.S. Nuclear Regulatory Commission, Washington, DC, October 1975. 


\section{APPENDIX A}

SPENT FUEL SHIPPING MODEL 
SPENT FUEL SHIPPING MODEL

In order to determine shipping distances between reactors and interim storage facilities or reactors and reprocessing plants, a shipment system model was developed. To simplify the analysis and reduce computer time, reactors either currently operating or planned for operation during the reference year $(1)$ were grouped according to reactor type (BWR or PWR) and location. A listing of the reactor groups is presented in Table A.l. Interim spent fuel storage facilities were assumed to be located at:

- Hanford, Washington

- Oak Ridge, Tennessee

- Morris, Illinois

- Barnwe1l, South Carolina

Reprocessing plants were assumed to be operating at Oak Ridge, Tennessee, and Barnwe11, South Carolina. A map showing the locations of reactor groups and spent fuel shipment receiving sites is shown in Figure 4.1 of Section 4.

Estimates of the amounts of spent fuel shipped per year from each reactor group were made based on the number, size and type of reactors in each group. From these amounts, the number of assemblies shipped and the number of shipments by train were calculated. Train shipments were assumed to account for $80 \%$ of all spent fuel shipped during the reference time period. The results of these calculations are tabulated in Tables A.2 and A.3.

\section{REFERENCE}

1. Nuclear News, 20(10):73, August 1977. 
TABLE A.1. Tabulation of Reactors and Reactor Groups

\begin{tabular}{|c|c|c|c|}
\hline Group No. & Reactor Name & Type & State \\
\hline 1 & Monticel10 & BWR & Minnesota \\
\hline 1 & La Crosse & BWR & Wiscons in \\
\hline 2 & Dresden 1 & BWR & Illinois \\
\hline 2 & Dresden 2 & BWR & Illinois \\
\hline 2 & Dresden 3 & BWR & Illinois \\
\hline 2 & Lasalle 1 & BWR & Illinois \\
\hline 2 & Lasalle 2 & BWR & Illinois \\
\hline 2 & Bailly & BWR & Indiana \\
\hline 2 & Clinton 1 & BWR & Illinois \\
\hline 2 & Clinton 2 & BWR & Illinois \\
\hline 3 & Quad Cities 1 & BWR & Illinois \\
\hline 3 & Quad Cities 2 & BWR & Illinois \\
\hline 3 & Duane Arnold 1 & BWR & Iowa \\
\hline 4 & Enrico Fermi 2 & BWR & Michigan \\
\hline 4 & Perry 1 & BWR & Ohio \\
\hline 4 & Perry 2 & BWR & Ohio \\
\hline 5 & Nine Mile Point 1 & BWR & New York \\
\hline 5 & Fitzpatrick 1 & BWR & New York \\
\hline 5 & Nine Mile Point 2 & BWR & New York \\
\hline 5 & Somerset 1 & BWR & New York \\
\hline 5 & Somerset 2 & BWR & New York \\
\hline 6 & Grand Gulf 1 & BWR & Mississippi \\
\hline 6 & Riverbend 1 & BWR & Louisiana \\
\hline 6 & Riverbend 2 & BWR & Louisiana \\
\hline 6 & Grand Gulf 2 & BWR & Mississippi \\
\hline 7 & Browns Ferry 1 & BWR & Alabama \\
\hline 7 & Browns Ferry 2 & BWR & Alabama \\
\hline 7 & Browns Ferry 3 & BWR & Al abama \\
\hline 7 & Barton 1 & BWR & Alabama \\
\hline 7 & Barton 2 & BWR & Al abama \\
\hline 7 & Barton 3 & BWR & Alabama \\
\hline 7 & Yellow Creek 1 & BWR & Mississippi \\
\hline 7 & Yellow Creek 2 & BWR & Mississippi \\
\hline 8 & Oyster Creek 1 & BWR & New Jersey \\
\hline 8 & Hope Creek 1 & BWR & New Jersey \\
\hline 8 & Hope Creek 2 & BWR & New Jersey \\
\hline 8 & Peach Bottom 2 & BWR & Pennsylvania \\
\hline 8 & Peach Bottom 3 & BWR & Pennsylvania \\
\hline 8 & Limerick 1 & BWR & Pennsylvania \\
\hline 8 & Limerick 2 & BWR & Pennsylvania \\
\hline
\end{tabular}


TABLE A.1. (contd)

\begin{tabular}{|c|c|c|c|}
\hline Group No. & Reactor Name & Type & State \\
\hline $\begin{array}{l}8 \\
8 \\
8 \\
8\end{array}$ & $\begin{array}{l}\text { Susquehanna } 1 \\
\text { Susquehanna } 2 \\
\text { Douglas Point } 1 \\
\text { Douglas Point } 2\end{array}$ & $\begin{array}{l}\text { BWR } \\
\text { BWR } \\
\text { BWR } \\
\text { BWR }\end{array}$ & $\begin{array}{l}\text { Pennsylvania } \\
\text { Pennsylvania } \\
\text { Maryland } \\
\text { Maryland }\end{array}$ \\
\hline $\begin{array}{l}9 \\
9 \\
9 \\
9 \\
9 \\
9\end{array}$ & $\begin{array}{l}\text { Millstone } 1 \\
\text { Pilgrim } 1 \\
\text { Shoreham } \\
\text { Vermont Yankee } \\
\text { Montague } 1 \\
\text { Montague } 2\end{array}$ & $\begin{array}{l}\text { BWR } \\
\text { BWR } \\
\text { BWR } \\
\text { BWR } \\
\text { BWR } \\
\text { BWR }\end{array}$ & $\begin{array}{l}\text { Connecticut } \\
\text { Massachusetts } \\
\text { New York } \\
\text { Vermont } \\
\text { Massachusetts } \\
\text { Massachusetts }\end{array}$ \\
\hline $\begin{array}{l}10 \\
10\end{array}$ & $\begin{array}{l}\text { Hatch } 1 \\
\text { Hatch } 2\end{array}$ & $\begin{array}{l}\text { BWR } \\
\text { BWR }\end{array}$ & $\begin{array}{l}\text { Georgia } \\
\text { Georgia }\end{array}$ \\
\hline $\begin{array}{l}11 \\
11\end{array}$ & $\begin{array}{l}\text { Brunswick } 2 \\
\text { Brunswich } 1\end{array}$ & $\begin{array}{l}\text { BWR } \\
\text { BWR }\end{array}$ & $\begin{array}{l}\text { North Carolina } \\
\text { North Carol ina }\end{array}$ \\
\hline $\begin{array}{l}12 \\
12\end{array}$ & $\begin{array}{l}\text { Zimmer } 1 \\
\text { Zimmer } 2\end{array}$ & $\begin{array}{l}\text { BWR } \\
\text { BWR }\end{array}$ & $\begin{array}{l}\text { Ohio } \\
\text { Ohio }\end{array}$ \\
\hline $\begin{array}{l}13 \\
13 \\
13 \\
13\end{array}$ & $\begin{array}{l}\text { Hartsville } 1 \\
\text { Hartsville } 2 \\
\text { Hartsville } 3 \\
\text { Hartsville } 4\end{array}$ & $\begin{array}{l}\text { BWR } \\
\text { BWR } \\
\text { BWR } \\
\text { BWR }\end{array}$ & $\begin{array}{l}\text { Tennessee } \\
\text { Tennessee } \\
\text { Tennessee } \\
\text { Tennessee }\end{array}$ \\
\hline $\begin{array}{l}14 \\
14\end{array}$ & $\begin{array}{l}\text { Allens Creek } 1 \\
\text { Allens Creek } 2\end{array}$ & $\begin{array}{l}\text { BWR } \\
\text { BWR }\end{array}$ & $\begin{array}{l}\text { Texas } \\
\text { Texas }\end{array}$ \\
\hline $\begin{array}{l}15 \\
15\end{array}$ & $\begin{array}{l}\text { Black Fox } 1 \\
\text { Black Fox } 2\end{array}$ & $\begin{array}{l}\text { BWR } \\
\text { BWR }\end{array}$ & $\begin{array}{l}\text { Oklahoma } \\
\text { Oklahoma }\end{array}$ \\
\hline $\begin{array}{l}16 \\
16\end{array}$ & $\begin{array}{l}\text { Skagit } 1 \\
\text { Skagit } 2\end{array}$ & $\begin{array}{l}\text { BWR } \\
\text { BWR }\end{array}$ & $\begin{array}{l}\text { Washington } \\
\text { Washington }\end{array}$ \\
\hline 17 & Cooper & BWR & Nebraska \\
\hline 18 & Big Rock Point & BWR & Michigan \\
\hline 19 & Humboldt Bay & BWR & California \\
\hline 20 & WPPSS 2 & BWR & Washington \\
\hline $\begin{array}{l}21 \\
21 \\
21\end{array}$ & $\begin{array}{l}\text { Trojan } \\
\text { WPPSS } 3 \\
\text { WPPSS } 5\end{array}$ & $\begin{array}{l}\text { PWR } \\
\text { PWR } \\
\text { PWR }\end{array}$ & $\begin{array}{l}\text { Oregon } \\
\text { Washington } \\
\text { Washington }\end{array}$ \\
\hline
\end{tabular}


TABLE A.1. (contd)

\begin{tabular}{|c|c|c|c|}
\hline Group No. & Reactor Name & Type & State \\
\hline $\begin{array}{l}22 \\
22 \\
22 \\
22\end{array}$ & $\begin{array}{l}\text { WPPSS } 1 \\
\text { Pebble Springs } 1 \\
\text { Pebble Springs } 2 \\
\text { WPPSS } 4\end{array}$ & $\begin{array}{l}\text { PWR } \\
\text { PWR } \\
\text { PWR } \\
\text { PWR }\end{array}$ & $\begin{array}{l}\text { Washington } \\
\text { Oregon } \\
\text { Oregon } \\
\text { Washington }\end{array}$ \\
\hline $\begin{array}{l}23 \\
23 \\
23\end{array}$ & $\begin{array}{l}\text { Prairie Island } 1 \\
\text { Prairie Island } 2 \\
\text { Tyrone } 1\end{array}$ & $\begin{array}{l}\text { PWR } \\
\text { PWR } \\
\text { PWR }\end{array}$ & $\begin{array}{l}\text { Minnesota } \\
\text { Minnesota } \\
\text { Wisconsin }\end{array}$ \\
\hline $\begin{array}{l}24 \\
24 \\
24 \\
24 \\
24 \\
24 \\
24 \\
24 \\
24 \\
24 \\
24 \\
24\end{array}$ & $\begin{array}{l}\text { Zion } 1 \\
\text { Zion } 2 \\
\text { Pal isades } \\
\text { Cook } 1 \\
\text { Cook 2 } \\
\text { Braidwood 1 } \\
\text { Braidwood 2 } \\
\text { Byron Township } 1 \\
\text { Byron Township } 2 \\
\text { Koshkonong 1 } \\
\text { Koshkonong } 2\end{array}$ & $\begin{array}{l}\text { PWR } \\
\text { PWR } \\
\text { PWR } \\
\text { PWR } \\
\text { PWR } \\
\text { PWR } \\
\text { PWR } \\
\text { PWR } \\
\text { PWR } \\
\text { PWR } \\
\text { PWR }\end{array}$ & $\begin{array}{l}\text { Illinois } \\
\text { Illinois } \\
\text { Michigan } \\
\text { Michigan } \\
\text { Michigan } \\
\text { Illinois } \\
\text { Illinois } \\
\text { Illinois } \\
\text { Illinois } \\
\text { Wisconsin } \\
\text { Wisconsin }\end{array}$ \\
\hline $\begin{array}{l}25 \\
25 \\
25\end{array}$ & $\begin{array}{l}\text { Point Beach } 1 \\
\text { Point Beach } 2 \\
\text { Kewaunee } 1\end{array}$ & $\begin{array}{l}\text { PWR } \\
\text { PWR } \\
\text { PWR }\end{array}$ & $\begin{array}{l}\text { Wiscons in } \\
\text { Wiscons in } \\
\text { Wiscons in }\end{array}$ \\
\hline $\begin{array}{l}26 \\
26 \\
26 \\
26 \\
26 \\
26 \\
26\end{array}$ & $\begin{array}{l}\text { Midland } 1 \\
\text { Midland } 2 \\
\text { Davis Besse } 1 \\
\text { Greenwood } 2 \\
\text { Greenwood } 3 \\
\text { Davis Besse } 2 \\
\text { Davis Besse } 3\end{array}$ & $\begin{array}{l}\text { PWR } \\
\text { PWR } \\
\text { PWR } \\
\text { PWR } \\
\text { PWR } \\
\text { PWR } \\
\text { PWR }\end{array}$ & $\begin{array}{l}\text { Michigan } \\
\text { Michigan } \\
\text { Ohio } \\
\text { Michigan } \\
\text { Michigan } \\
\text { Ohio } \\
\text { Ohio }\end{array}$ \\
\hline $\begin{array}{l}27 \\
27\end{array}$ & $\begin{array}{l}\text { Ginna } 1 \\
\text { Sterling }\end{array}$ & $\begin{array}{l}\text { PWR } \\
\text { PWR }\end{array}$ & $\begin{array}{l}\text { New York } \\
\text { New York }\end{array}$ \\
\hline $\begin{array}{l}28 \\
28 \\
28 \\
28 \\
28 \\
28\end{array}$ & $\begin{array}{l}\text { Comanche Peak } 1 \\
\text { Comanche Peak } 2 \\
\text { Blue Hills } 1 \\
\text { Blue Hills } 2 \\
\text { South Texas } 1 \\
\text { South Texas } 2\end{array}$ & $\begin{array}{l}\text { PWR } \\
\text { PWR } \\
\text { PWR } \\
\text { PWR } \\
\text { PWR } \\
\text { PWR }\end{array}$ & $\begin{array}{l}\text { Texas } \\
\text { Texas } \\
\text { Texas } \\
\text { Texas } \\
\text { Texas } \\
\text { Texas }\end{array}$ \\
\hline $\begin{array}{l}29 \\
29 \\
29 \\
29\end{array}$ & $\begin{array}{l}\text { Turkey Point } 3 \\
\text { Turkey Point } 4 \\
\text { St. Lucie } 1 \\
\text { St. Lucie } 2\end{array}$ & $\begin{array}{l}\text { PWR } \\
\text { PWR } \\
\text { PWR } \\
\text { PWR }\end{array}$ & $\begin{array}{l}\text { Florida } \\
\text { Florida } \\
\text { Florida } \\
\text { Florida }\end{array}$ \\
\hline
\end{tabular}


TABLE A. 1. (contd)

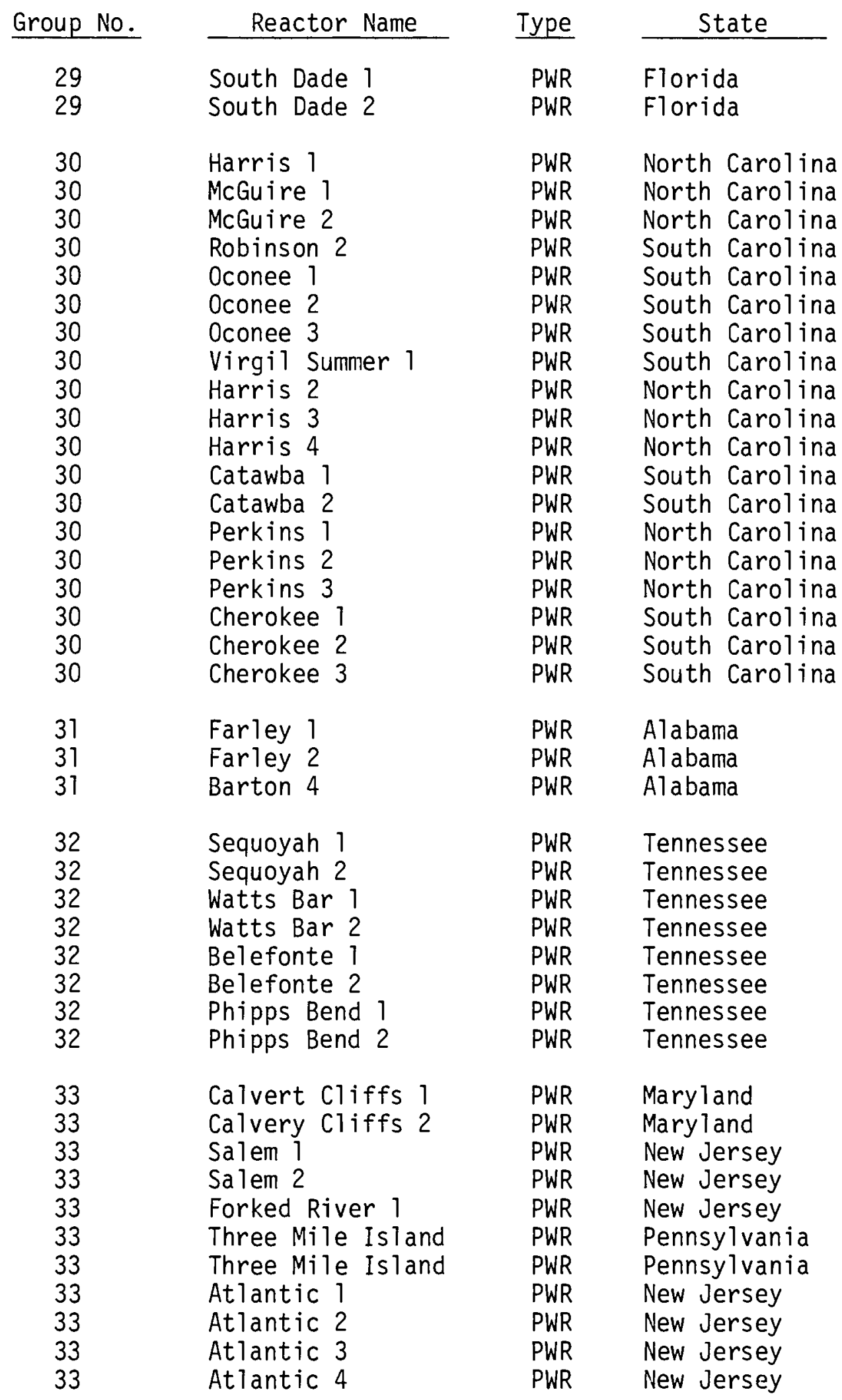


TABLE A.1. (contd)

\begin{tabular}{|c|c|c|c|}
\hline Group No. & Reactor Name & Type & State \\
\hline $\begin{array}{l}34 \\
34 \\
34 \\
34 \\
34 \\
34 \\
34 \\
34 \\
34 \\
34 \\
34 \\
34 \\
34 \\
34 \\
34\end{array}$ & $\begin{array}{l}\text { Connecticut Yankee } \\
\text { Millstone } 2 \\
\text { Yankee } \\
\text { Indian Point } 1 \\
\text { Indian Point } 2 \\
\text { Indian Point } 3 \\
\text { Jamesport 2 } \\
\text { Jamesport } 1 \\
\text { Pilgrim } \\
\text { Seabrook } 1 \\
\text { Seabrook } 2 \\
\text { Nep } 1 \\
\text { Millstone } 3 \\
\text { Nep 2 } \\
\text { Green County }\end{array}$ & $\begin{array}{l}\text { PWR } \\
\text { PWR } \\
\text { PWR } \\
\text { PWR } \\
\text { PWR } \\
\text { PWR } \\
\text { PWR } \\
\text { PWR } \\
\text { PWR } \\
\text { PWR } \\
\text { PWR } \\
\text { PWR } \\
\text { PWR } \\
\text { PWR } \\
\text { PWR }\end{array}$ & $\begin{array}{l}\text { Connecticut } \\
\text { Connecticut } \\
\text { Massachusetts } \\
\text { New York } \\
\text { New York } \\
\text { New York } \\
\text { New York } \\
\text { New York } \\
\text { Massachusetts } \\
\text { New Hampshire } \\
\text { New Hampshire } \\
\text { Rhode Island } \\
\text { Connecticut } \\
\text { Rhode Island } \\
\text { New York }\end{array}$ \\
\hline $\begin{array}{l}35 \\
35\end{array}$ & $\begin{array}{l}\text { Maine Yankee } \\
\text { Sears Island }\end{array}$ & $\begin{array}{l}\text { PWR } \\
\text { PWR }\end{array}$ & $\begin{array}{l}\text { Maine } \\
\text { Maine }\end{array}$ \\
\hline $\begin{array}{l}36 \\
36 \\
36 \\
36 \\
36 \\
36 \\
36 \\
36\end{array}$ & $\begin{array}{ll}\text { Surry } 4 \\
\text { Surry } 1 \\
\text { Surry } 2 \\
\text { North Anna } 1 \\
\text { North Anna } 2 \\
\text { North Anna } 3 \\
\text { North Anna } 4 \\
\text { Surry } 3\end{array}$ & $\begin{array}{l}\text { PWR } \\
\text { PWR } \\
\text { PWR } \\
\text { PWR } \\
\text { PWR } \\
\text { PWR } \\
\text { PWR } \\
\text { PWR }\end{array}$ & $\begin{array}{l}\text { Virginia } \\
\text { Virginia } \\
\text { Virginia } \\
\text { Virginia } \\
\text { Virginia } \\
\text { Virginia } \\
\text { Virginia } \\
\text { Virginia }\end{array}$ \\
\hline $\begin{array}{l}37 \\
37 \\
37\end{array}$ & $\begin{array}{l}\text { Diablo Canyon } 1 \\
\text { Diablo Canyon } 2 \\
\text { Rancho Seco }\end{array}$ & $\begin{array}{l}\text { PWR } \\
\text { PWR } \\
\text { PWR }\end{array}$ & $\begin{array}{l}\text { California } \\
\text { California } \\
\text { California }\end{array}$ \\
\hline $\begin{array}{l}38 \\
38 \\
38\end{array}$ & $\begin{array}{l}\text { Beaver Valley } 1 \\
\text { Shippingport } \\
\text { Beaver Valley } 2\end{array}$ & $\begin{array}{l}\text { PWR } \\
\text { PWR } \\
\text { PWR }\end{array}$ & $\begin{array}{l}\text { Pennsylvania } \\
\text { Pennsylvania } \\
\text { Pwnnsylvania }\end{array}$ \\
\hline $\begin{array}{l}39 \\
39\end{array}$ & $\begin{array}{ll}\text { Arkansas } 1 \\
\text { Arkansas } 2\end{array}$ & $\begin{array}{l}\text { PWR } \\
\text { PWR }\end{array}$ & $\begin{array}{l}\text { Arkansas } \\
\text { Arkansas }\end{array}$ \\
\hline $\begin{array}{l}40 \\
40 \\
40\end{array}$ & $\begin{array}{l}\text { San Onofre } 1 \\
\text { San Onofre } 2 \\
\text { San Onofre } 3\end{array}$ & $\begin{array}{l}\text { PWR } \\
\text { PWR } \\
\text { PWR }\end{array}$ & $\begin{array}{l}\text { California } \\
\text { Cal ifornia } \\
\text { California }\end{array}$ \\
\hline $\begin{array}{l}41 \\
41\end{array}$ & $\begin{array}{l}\text { Fort Calhoun } 1 \\
\text { Fort Calhoun } 2\end{array}$ & $\begin{array}{l}\text { PWR } \\
\text { PWR }\end{array}$ & $\begin{array}{l}\text { Nebraska } \\
\text { Nebraska }\end{array}$ \\
\hline
\end{tabular}


TABLE A.1. (contd)

\begin{tabular}{|c|c|c|c|}
\hline Group No. & Reactor Name & Type & State \\
\hline $\begin{array}{l}42 \\
42\end{array}$ & $\begin{array}{l}\text { Callaway } 1 \\
\text { Callaway } 3\end{array}$ & $\begin{array}{l}\text { PWR } \\
\text { PWR }\end{array}$ & $\begin{array}{l}\text { Missouri } \\
\text { Missouri }\end{array}$ \\
\hline $\begin{array}{l}43 \\
43 \\
43\end{array}$ & $\begin{array}{l}\text { Palo Verde } 1 \\
\text { Palo Verde } 2 \\
\text { Palo Verde } 3\end{array}$ & $\begin{array}{l}\text { PWR } \\
\text { PWR } \\
\text { PWR }\end{array}$ & $\begin{array}{l}\text { Arizona } \\
\text { Arizona } \\
\text { Arizona }\end{array}$ \\
\hline $\begin{array}{l}44 \\
44\end{array}$ & $\begin{array}{l}\text { Marble Hill } 2 \\
\text { Marble Hill } 1\end{array}$ & $\begin{array}{l}\text { PWR } \\
\text { PWR }\end{array}$ & $\begin{array}{l}\text { Indiana } \\
\text { Indiana }\end{array}$ \\
\hline 45 & Crystal River 3 & PWR & Florida \\
\hline 46 & Waterford 3 & PWR & Louisiana \\
\hline 47 & Wolf Creek & PWR & Kansas \\
\hline
\end{tabular}

TABLE A.2. Spent Fuel Shipments by Train from Reactors to Storage Facilities

\begin{tabular}{|c|c|c|c|c|c|c|c|}
\hline R.G. & $\begin{array}{l}\text { Reactor } \\
\text { Type }\end{array}$ & $\begin{array}{l}\text { Miles to } \\
\text { Nearest } \\
\text { Storage } \\
\text { Facility }\end{array}$ & $\begin{array}{c}\mathrm{Mg} \\
\text { Shipped/ } \\
\text { Year } \\
\end{array}$ & $\begin{array}{l}\text { Number } \\
\text { of } \\
\text { Assemblies } \\
\text { Shipped } \\
\end{array}$ & $\begin{array}{l}\text { Number } \\
\text { Shipped by } \\
\text { Train }(80 \%)\end{array}$ & $\begin{array}{c}\text { Train } \\
\text { Shipments }\end{array}$ & $\begin{array}{l}\text { Shipment- } \\
\text { Miles }(\mathrm{a})\end{array}$ \\
\hline 1 & BWR & 470 & 8 & 48 & 38 & 3 & $1.41 \times 10^{3}$ \\
\hline 2 & BWR & 130 & 80 & 483 & 386 & 22 & $2.86 \times 10^{3}$ \\
\hline 3 & BWR & 200 & 32 & 193 & 154 & 9 & $1.80 \times 10^{3}$ \\
\hline 4 & BWR & 410 & 45 & 272 & 218 & 13 & $5.33 \times 10^{3}$ \\
\hline 5 & BWR & 660 & 37 & 223 & 178 & 10 & $6.60 \times 10^{3}$ \\
\hline 6 & BWR & 480 & 28 & 169 & 135 & 8 & $3.84 \times 10^{3}$ \\
\hline 7 & BWR & 210 & 49 & 296 & 237 & 14 & $2.94 \times 10^{3}$ \\
\hline 8 & BWR & 560 & 110 & 664 & 531 & 30 & $1.68 \times 10^{4}$ \\
\hline 9 & BWR & 790 & 40 & 241 & 193 & 11 & $8.69 \times 10^{4}$ \\
\hline 10 & BWR & 70 & 27 & 163 & 130 & 8 & $5.60 \times 10^{2}$ \\
\hline 11 & BWR & 230 & 24 & 145 & 116 & 7 & $1.61 \times 10^{3}$ \\
\hline 12 & BWR & 230 & 12 & 72 & 58 & 4 & $9.2 \times 10^{2}$ \\
\hline 13 & BWR & 120 & 50 & 302 & 242 & 14 & $1.68 \times 10^{3}$ \\
\hline 14 & BWR & 780 & 30 & 181 & 145 & 9 & $7.02 \times 10^{3}$ \\
\hline 15 & BWR & 420 & 0 & 0 & 0 & 0 & 0 \\
\hline
\end{tabular}


TABLE A.2. (contd)

\begin{tabular}{|c|c|c|c|c|c|c|c|}
\hline R.G. & $\begin{array}{l}\text { Reactor } \\
\text { Type } \\
\end{array}$ & $\begin{array}{l}\text { Miles to } \\
\text { Nearest } \\
\text { Storage } \\
\text { Facility }\end{array}$ & $\begin{array}{c}\text { Mg } \\
\text { Shipped/ } \\
\text { Year } \\
\end{array}$ & $\begin{array}{c}\text { Number } \\
\text { of } \\
\text { Assemb } 1 \text { ies } \\
\text { Shipped } \\
\end{array}$ & $\begin{array}{l}\text { Number } \\
\text { Shipped by } \\
\text { Train }(80 \%) \\
\end{array}$ & $\begin{array}{c}\text { Train } \\
\text { Shipments } \\
\end{array}$ & $\begin{array}{l}\text { Shipment- } \\
\text { Miles }(a)\end{array}$ \\
\hline 16 & BWR & 180 & 16 & 97 & 78 & 5 & $9.0 \times 10^{2}$ \\
\hline 17 & BWR & 360 & 12 & 72 & 58 & 4 & $1.44 \times 10^{3}$ \\
\hline 18 & BWR & 460 & 2 & 12 & 10 & 1 & $4.60 \times 10^{2}$ \\
\hline 19 & BWR & 470 & 2 & 12 & 10 & 1 & $4.70 \times 10^{2}$ \\
\hline 20 & BWR & 10 & 17 & 103 & 82 & 5 & $5.0 \times 10^{1}$ \\
\hline 21 & PWR & 180 & 41 & 83 & 66 & 10 & $1.80 \times 10^{3}$ \\
\hline 22 & PWR & 40 & 42 & 85 & 68 & 10 & $4.00 \times 10^{2}$ \\
\hline 23 & PWR & 410 & 14 & 28 & 22 & 4 & $1.64 \times 10^{3}$ \\
\hline 24 & PWR & 200 & 131 & 264 & 211 & 31 & $6.20 \times 10^{3}$ \\
\hline 25 & PWR & 350 & 22 & 44 & 35 & 5 & $1.75 \times 10^{3}$ \\
\hline 26 & PWR & 380 & 52 & 105 & 84 & 12 & $4.56 \times 10^{3}$ \\
\hline 27 & PWR & 670 & 7 & 14 & 11 & 2 & $1.34 \times 10^{3}$ \\
\hline 28 & PWR & 730 & 53 & 107 & 86 & 13 & $9.49 \times 10^{3}$ \\
\hline 29 & PWR & 450 & 59 & 119 & 95 & 14 & $6.30 \times 10^{3}$ \\
\hline 30 & PWR & 190 & 127 & 256 & 205 & 30 & $5.70 \times 10^{3}$ \\
\hline 31 & PWR & 200 & 21 & 42 & 34 & 5 & $1.00 \times 10^{3}$ \\
\hline 32 & PWR & 100 & 95 & 191 & 153 & 22 & $2.20 \times 10^{3}$ \\
\hline 33 & PWR & 570 & 93 & 187 & 150 & 22 & $1.25 \times 10^{4}$ \\
\hline 34 & PWR & 780 & 152 & 306 & 245 & 35 & $2.73 \times 10^{4}$ \\
\hline 35 & PWR & 1000 & 25 & 50 & 40 & 6 & $6.00 \times 10^{3}$ \\
\hline 36 & PWR & 420 & 78 & 157 & 126 & 18 & $7.56 \times 10^{3}$ \\
\hline 37 & PWR & 730 & 40 & 81 & 65 & 10 & $7.30 \times 10^{3}$ \\
\hline 38 & PWR & 410 & 22 & 44 & 35 & 5 & $2.05 \times 10^{3}$ \\
\hline 39 & PWR & 360 & 24 & 48 & 38 & 6 & $2.16 \times 10^{3}$ \\
\hline 40 & PWR & 920 & 24 & 48 & 38 & 6 & $5.52 \times 10^{3}$ \\
\hline 41 & PWR & 400 & 19 & 38 & 30 & 5 & $2.00 \times 10^{3}$ \\
\hline 42 & PWR & 160 & 26 & 52 & 42 & 6 & $9.60 \times 10^{2}$ \\
\hline 43 & PWR & 980 & 13 & 26 & 21 & 3 & $2.94 \times 10^{3}$ \\
\hline 44 & PWR & 190 & 13 & 26 & 21 & 3 & $5.70 \times 10^{2}$ \\
\hline
\end{tabular}


TABLE A.2. (contd)

\begin{tabular}{|c|c|c|c|c|c|c|c|}
\hline R.G. & $\begin{array}{l}\text { Reactor } \\
\text { Type } \\
\end{array}$ & $\begin{array}{l}\text { Miles to } \\
\text { Nearest } \\
\text { Storage } \\
\text { Facility }\end{array}$ & $\begin{array}{c}\text { Mg } \\
\text { Shipped/ } \\
\text { Year } \\
\end{array}$ & $\begin{array}{c}\text { Number } \\
\text { of } \\
\text { Assemblies } \\
\text { Shipped } \\
\end{array}$ & $\begin{array}{l}\text { Number } \\
\text { Shipped by } \\
\text { Train }(80 \%) \\
\end{array}$ & $\begin{array}{c}\text { Train } \\
\text { Shipments } \\
\end{array}$ & $\begin{array}{l}\text { Shipment } \\
\text { Miles }(a)\end{array}$ \\
\hline 45 & PWR & 260 & 13 & 26 & 21 & 3 & $7.80 \times 10^{2}$ \\
\hline 46 & PWR & 520 & 15 & 30 & 24 & 4 & $2.08 \times 10^{3}$ \\
\hline 47 & PWR & 370 & 13 & 26 & 21 & 3 & $1.11 \times 10^{5}$ \\
\hline Total & \multicolumn{5}{|c|}{1854} & 471 & $2.67 \times 10^{5}$ \\
\hline
\end{tabular}

(a) One mile $=1.61 \mathrm{~km}$. 
TABLE A.3. Spent Fuel Shipments by Train from Reactors to Fuel Reprocessing Plants

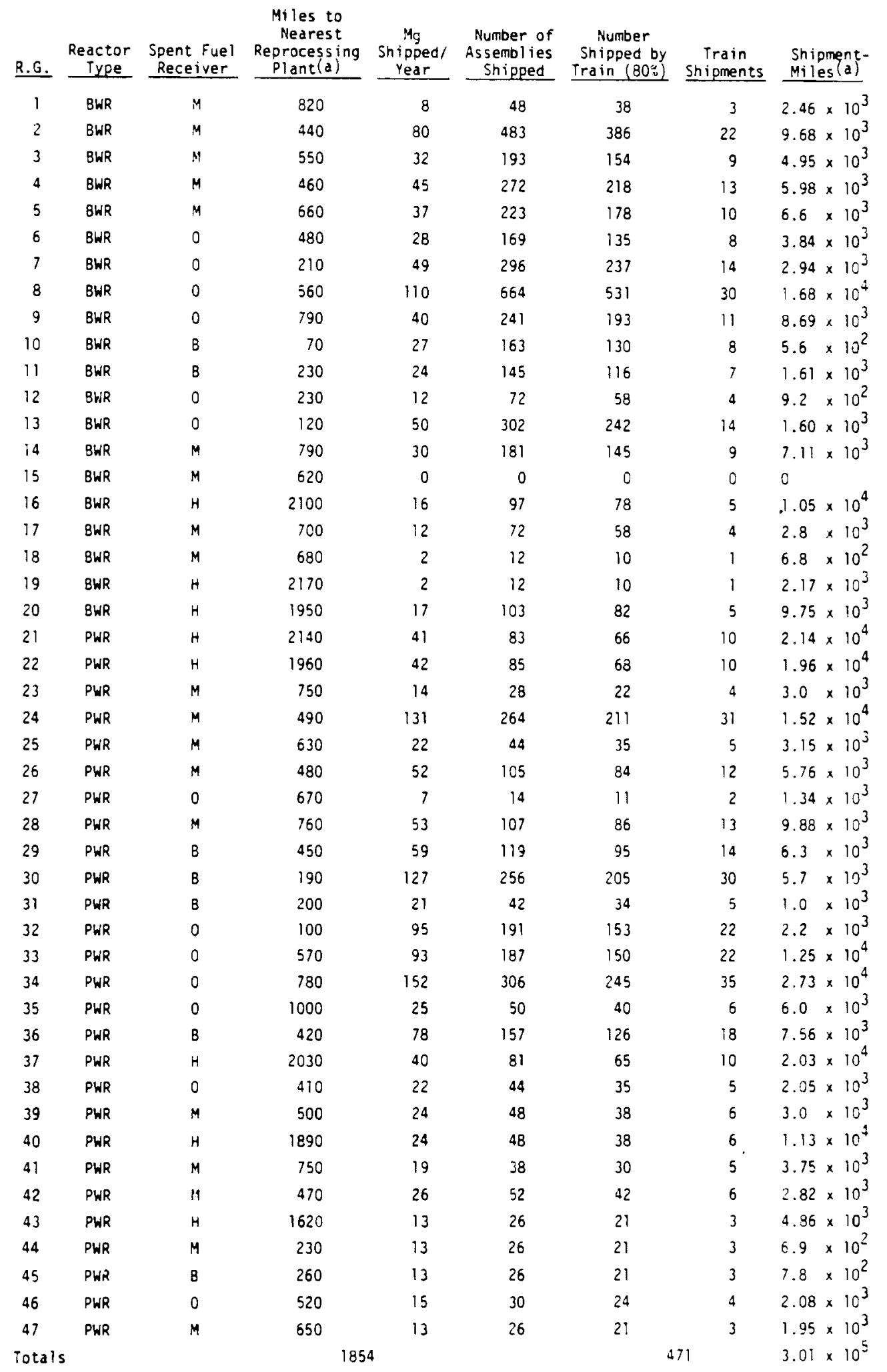

(a) One mile $=1.6 \mathrm{~km}$. 
APPENDIX B

DESCRIPTION OF REFERENCE SPENT FUEL RAIL SHIPPING CASK 
APPENDIX B

\section{DESCRIPTION OF REFERENCE SPENT FUEL RAIL SHIPPING CASK}

The reference cask used for analysis in this study is water-filled and air-cooled and is designed for rail transport of 7 PWR or 18 BWR fuel assemblies. The two types of fuel are accommodated through the use of removable fuel baskets and two different length closure heads. Approximate loaded cask weight is 63 megagrams $(140,000 \mathrm{lb})$. The gross weight of the cask, including skid and auxiliary components is 84 megagrams $(185,0001 \mathrm{~b})$. The cask is normally transported by rail on a 100-metric ton capacity, four-axle flatcar. The cask is mounted on its skid in a horizontal position during transfer and is supported by a saddle at the head end and a cradle at the bottom end. The cradle forms the pivot about which the cask is rotated for vertical removal from the skid. The cask is lifted by a special yoke which is designed to be used with either length head. The cask is enclosed during transport by an aluminum frame and expanded metal cage.

All external and internal surfaces of the cask are stainless steel. Both gamma and fast neutron shielding are provided by water in the cask cavity, depleted uranium metal within the cask she11, and an exterior water-filled enclosure which is fabricated from thin-walled stainless steel and is corrugated to maximize the heat transfer area. These corrugations also significantly increase the strength of the outer jacket and its resistance to damage. The cylindrical containment is attached to the cask body and shields the active fuel zone.

The closure head is sealed with a metallic gasket. The maximum normal operating pressure for the cask cavity is $1.4 \mathrm{MPa}$ (gage) (200 psig) and the design working pressure is $2.8 \mathrm{MPa}$ (gage) (400 psig) at a material temperature of $435^{\circ} \mathrm{C}\left(815^{\circ} \mathrm{F}\right)$. Overpressure protection is provided by a pressure relief valve, with a discharge pressure of $2.6 \mathrm{MPa}$ (gage) (375 psig). The valve is set for a maximum steam or gas blowdown of $5 \%$ and a 1 iquid blowdown of $10 \%$. The cask cavity is equipped with two nuclear service valves, one of each of 
two valve boxes, for filling, draining, venting and sampling. These valves have quick disconnect fittings for each in servicing. The shielding water containment is protected from overpressure by a $1.4 \mathrm{MPa}$ (gage) (200-psig) relief valve. It is also serviced by fill and drain valves located in the two valve boxes.

Fuel assemblies are contained within a removable, slotted, stainless steel basket. Two alternate baskets are available, one designed to accommodate BWR assemblies and one for the PWR assemblies. Fuel elements are restrained axially by spacers mounted on the inside of the closure head. The basket is centered within the cask cavity by nine disc spacers, mounted along the fuel basket using standard grapples. Basket removal is made only when the cask is to be used for the shipment of another fuel type.

The outer surfaces of the cask body, including the cask ends and valve boxes, are finned for impact protection. These fins are stainless steel and are welded to the cask surface. Figure B.l shows a cutaway view of the cask and Figure B.2 shows the cask in the normal rail transport configuration.

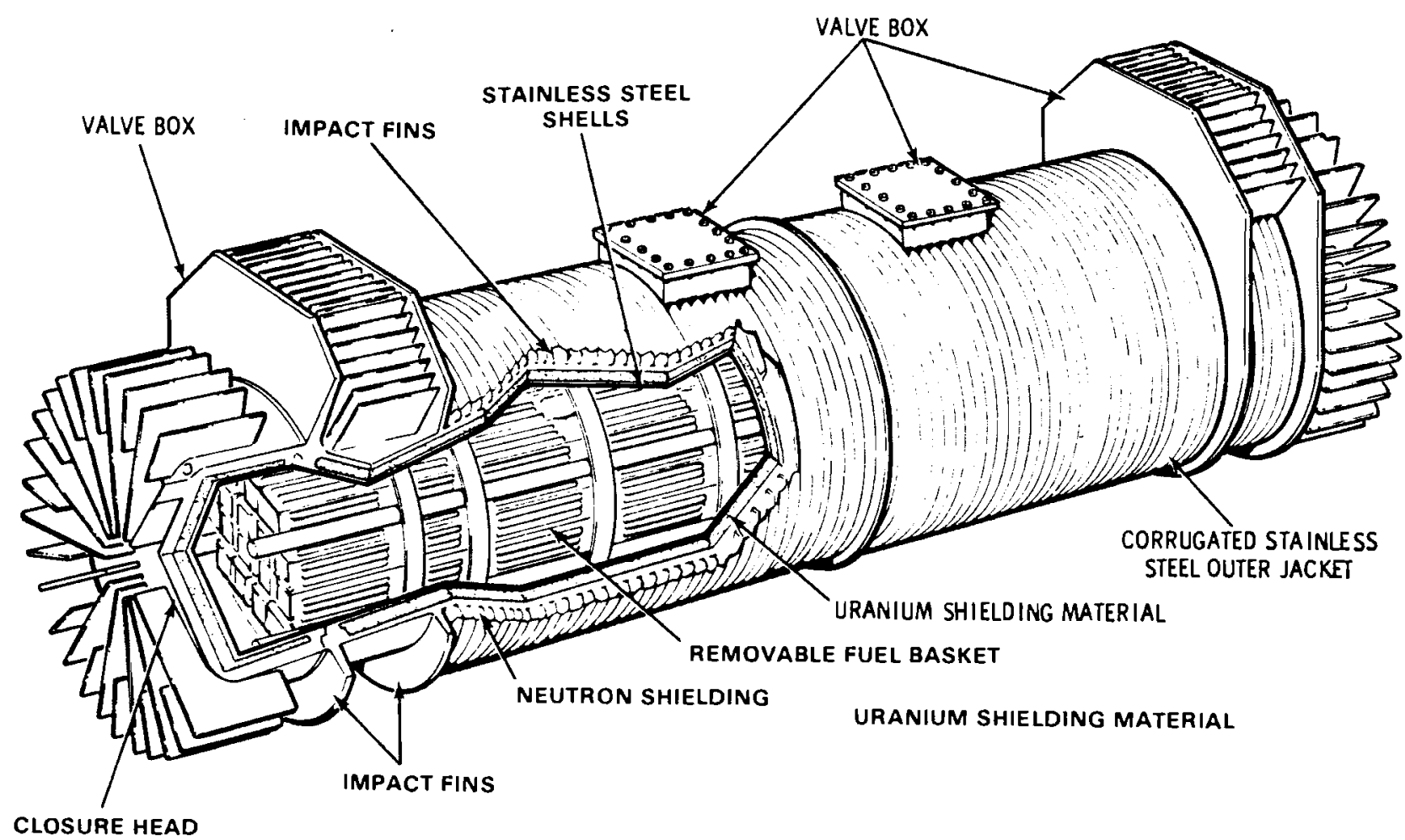

FIGURE B.1. Reference Spent Fuel Shipping Cask 


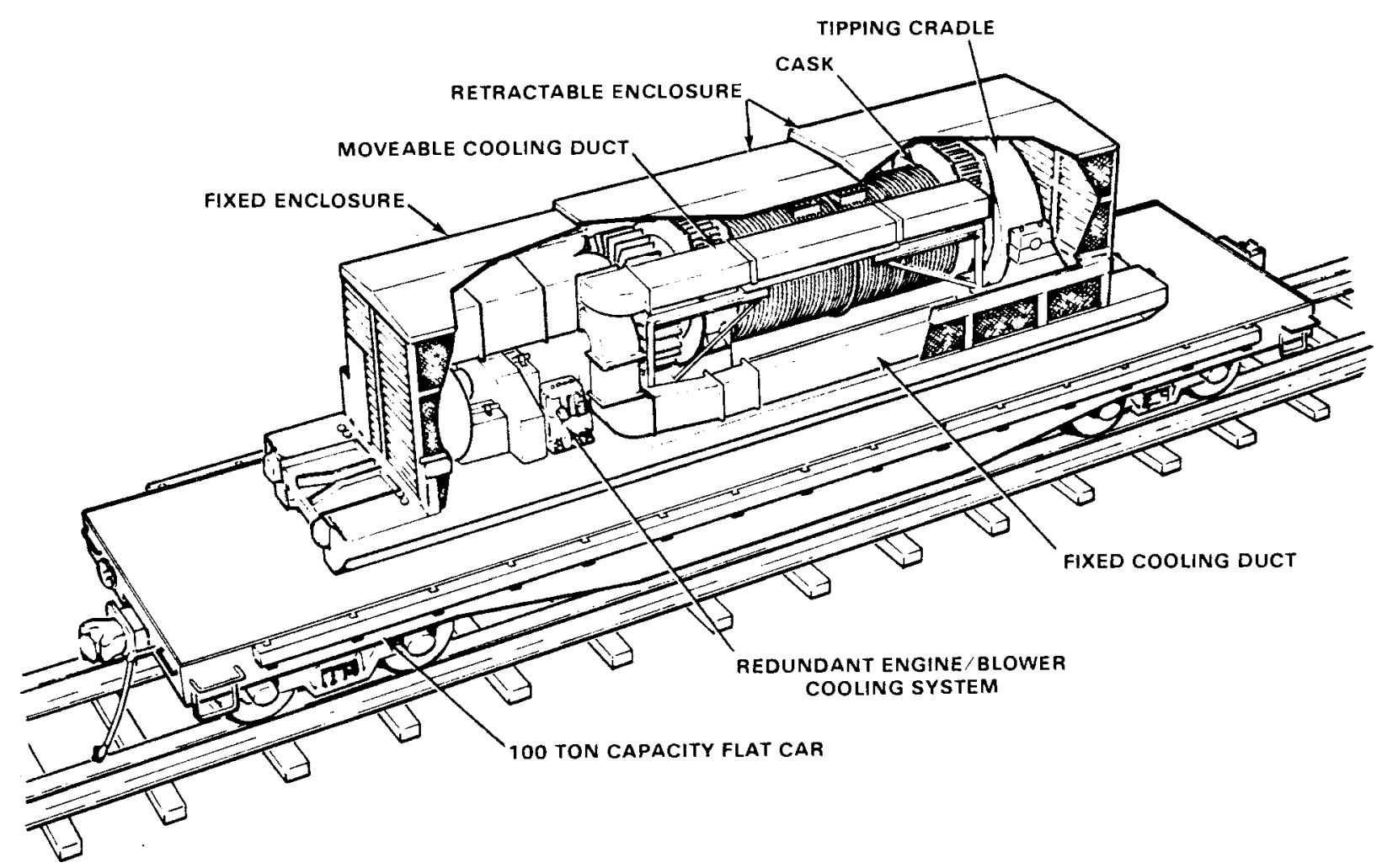

FIGURE B.2. Reference Spent Fuel Shipping Cask in Normal Rail Transport Configuration

Table B. 1 summarizes the characteristics of the design basis fuels and cask. Table B.2 gives data on the characteristics of the fuel used in the analyses for this study.

The cask inner cavity is a stainless steel cylinder, $95.2 \mathrm{~cm}(37-1 / 2 \mathrm{in}$.$) ,$ ID with $1.27 \mathrm{~cm}(1-1 / 2$ in.) thick walls, having its bottom end sealed with a $3.8 \mathrm{~cm}(1-1 / 2 \mathrm{in.})$ thick stainless steel plate. The upper end is welded to the closure flange.

Surrounding the inner cavity is the depleted uranium metal shielding material. This heavy metal assembly consists of annular castings, each with a $97.8 \mathrm{~cm}$ (382 in.) ID and a 10.2-cm (4-in.)-thick wall. Sections are interlocked, end-to-end, using an overlapping joint which holds the stack together and prevents radiation streaming. This assembly is shrink-fitted to the inner cavity to ensure good thermal contact for heat transfer purposes. The bottom end shield is a $9.5-\mathrm{cm}$ (3-3/4-in.)-thick uranium metal casting. 
TABLE B.1. Characteristics of Design Bas is Fuels and Cask

\begin{tabular}{|c|c|c|}
\hline Type & BWR & PWR \\
\hline \multicolumn{3}{|l|}{ Fuels } \\
\hline Exposure, GWd/MTU (average) & 35.0 & 35.0 \\
\hline Operating Power, kW/kgU & 30.0 & 40.0 \\
\hline Assembly Heat Power, W/kgu & 19.70 & 24.03 \\
\hline Assemblies per Cask Load & 18 & 7 \\
\hline Uranium, kgU/Assembly & 197 & 475 \\
\hline Maximum Decay Heat Rate-Cask, kW & 238,000 & 262,000 \\
\hline \multicolumn{3}{|l|}{ Cask } \\
\hline Cavity Length, $\mathrm{cm}$ & 475.2 (180 in.) & $429.9(160.2$ in. $)$ \\
\hline Cavity Diameter, $\mathrm{cm}$ & 95.2 (37.5 in.) & $95.2(37.5$ in.) \\
\hline Inner Shell Thickness, $\mathrm{cm}$ & 1.27 (0.5 in.) & 1.27 (0.5 in.) \\
\hline Shielding Thickness, $\mathrm{cm}$ & $10.2(4.0$ in.) & $10.2(4.0$ in. $)$ \\
\hline Outer She11 Thickness, cm & $3.8(1.5$ in. $)$ & 3.8 (1.5 in.) \\
\hline Cask Length, Excluding Fins, $\mathrm{cm}$ & 981.5 & 482.9 \\
\hline Cask Cavity Water, liters & $2,310(5,1001 b)$ & $2,090(4,800$ 1b $)$ \\
\hline Shielding Water, liters & $2,060(4,5401 b)$ & $2,060(4,5401 \mathrm{lb})$ \\
\hline Cavity Relief Pressure, atm & $23.8(350 \mathrm{psig})$ & \\
\hline Exterior Containing Relief Pressure, atm & 13.6 (200 psig) & \\
\hline \multicolumn{3}{|l|}{ Cooling System } \\
\hline Cooling Medium & Forced Air & Forced Air \\
\hline Number of Full-Length Cooling Nozzles & 4 & 4 \\
\hline Cooling Air Arrival Velocity & $47.0 \mathrm{fps}$ & $47.0 \mathrm{fps}$ \\
\hline System Classification & Open & Open \\
\hline Surface Film Coefficient & 7.0 & 7.0 \\
\hline Minimum Air Flow & $(10,000 \mathrm{cfm})$ & $(10,000 \mathrm{cfm})$ \\
\hline
\end{tabular}

The outer body shell is also a stainless steel cylinder with a $118.1 \mathrm{~cm}$ $(46-1 / 2$ in.) ID and a $3.8 \mathrm{~cm}(1-1 / 2$ in.) thick wall. The outer shell is also shrink-fitted to the uranium to ensure good heat transfer characteristics.

The cylindrical portion of the cask is encircled by a thin-walled, corrugated stainless steel water jacket, extending axially from the upper valve 
TABLE B.2. Characteristics of Design Basis PWR Fuel

Fuel Assembly

$\begin{array}{lc}\text { Overall Dimensions, in. (slotted envelope) } & 8.576 \times 8 \times 576(\mathrm{a}) \\ \text { Active Length } & 365 \mathrm{~cm}(144 \mathrm{in} .) \\ \text { Length } & 386 \mathrm{~cm}(152 \mathrm{in} .) \\ \text { Number of Fuel Rods } & 289 \\ \text { Pin Array } & 17 \times 17 \\ \text { Pin Pitch } & 1.26 \mathrm{~cm}(0.496 \mathrm{in.}) \\ \text { Pin Diameter } & 0.949 \mathrm{~cm}(0.374 \mathrm{in.}) \\ \text { Pin Clad Thickness } & 0.0572 \mathrm{~cm}(0.0225 \mathrm{in} .) \\ \text { Weight, kg } & 680.4(1,5001 \mathrm{~b}) \\ \text { Enrichment, w/o }{ }^{235} \mathrm{U} & 3.6 \\ \text { Weight, U } & 461.4 \mathrm{~kg} \\ \text { H/U Ratio } & 5.72\end{array}$

(a) in. $\times 2.54^{2} \mathrm{~cm}$.

box to a point slightly above the cask bottom, thus masking the active fuel zone. Water contained in this structure functions as a neutron shield. An antifreeze and water mixture is used when the cask is subject to cold ambient temperature conditions. The jacket surface is corrugated for heat transfer purposes. Additionally, the use of continuous corrugation provides rating of 200 psig and is equipped with fill, flush, and relief valves.

Welded to the outer shel1 OD are four $17.8 \mathrm{~cm}$ (7 in.) high and $3.2 \mathrm{~cm}$ (1-1/4 in.) thick circumferential fins. These members serve as lifting rings and impact fins. They are also used to support the water jacket sections. The cask is lifted by a set of trunnions located just below the closure head flange. These lifting trunnions are pinned to the upper set of heavy rings and are designed to be removed for transit. The upper set of lifting rings also acts as the forward support/axial restraint when the cask is in the horizontal transport position. 
Radially mounted at the lower end of the cask are 32 stainless steel impact fins, $3.2 \mathrm{~cm}(1-1 / 4 \mathrm{in.})$ thick and approximately $20.3 \mathrm{~cm}$ (8 in.) high.

There are two large valve boxes on the exterior of the cask body located between the pairs of impact fins. These fixtures have finned lids which are removed during loading. The head end valve box contains both a nuclear service vent and flush valve and a pressure relief valve. The lower box contains a fill and flush valve only. Stainless steel Schedule 40 pipe connects the upper valves to the cask cavity side wall near the flange. The lower valve is connected to the inner cavity bottom, 180 degrees from the upper valve location.

The overall length of the cask body from fins to flange face is $467.8 \mathrm{~cm}$ (184-3/16 in.). The cask cavity depth from the flange face is $430.5 \mathrm{~cm}$ (169-1/2 in.). The flange is a stainless steel machined forging whose face contains 32 equally spaced studs, each of which is $4.5 \mathrm{~cm}(1-3 / 4$ in.) in diameter.

\section{CASK HEADS}

The cask can be equipped with either of two different heads. These heads provide two alternate cask cavity lengths to match the particular dimensions of the fuel being shipped. With the short head in place, the overall cavity length is $430.5 \mathrm{~cm}(169-1 / 2 \mathrm{in}$.$) . The long head increases the cavity to$ $457.2 \mathrm{~cm}$ (180 in.). Most PWR fuel will be shipped using the short (PWR) head. BWR fuel (and some longer designs of PWR fuel) necessitates using the extended (BWR) head.

Shielding in the heads consists of $7.6 \mathrm{~cm}$ (3 in.) of uranium. The outer shell and flange is a single stainless steel machined casting. A circular stainless steel plate is welded in place to form the head cover.

Each head has 32 radialiy mounted fins on the end, 16 of which protrude $24.1 \mathrm{~cm}(9-1 / 2 \mathrm{in.})$ from the surface. The remaining fins protrude $15.2 \mathrm{~cm}$ (6 in.) from the surface. These fins are designed to provide impact protection to the cask and contents. These fins are stainless steel and are welded in place. 
Cask sealing is accomplished using a metallic gasket. The head and body flanges interlock to provide shear steps to protect the gasket during impact. The gasket is designed for a minimum $40.8 \mathrm{~atm}$ (600 psi) burst pressure and a maximum operating temperature of $815^{\circ} \mathrm{C}\left(1500^{\circ} \mathrm{F}.\right)$.

\section{FUEL BASKETS}

Two different fuel baskets will be used in the cask--a 7-cell PWR unit and an 18-cell BWR unit. Each basket "cell" is a square, thin-walled stainless steel tube, the walls of which are slotted to provide coolant flow to the

contained fuel. Cells are held in place by nine circular spacers equally placed along the basket length. These same spacers center the basket in the cask cavity. The basket cells run the full length of the fuel. When the cask is horizontal, the weight of the fuel assemblies is carried by the spacer discs. Cells are not principal load carrying members; they function as guides for each in fuel loading. Both baskets are of welded, stainless steel construction and are keyed into the cask to prevent rotation during shipment.

\section{EQUIPMENT SKID}

The equipment skid functions as a unitized pallet for the cask and cooling equipment. The skid frame uses $70 \mathrm{~cm}$ (24 in.) fabricated I-beams. Fuel tanks for the cooling system diesels are incorporated into the framing. The cooling system and cask support members are attached directly to the frame. The skid is $11.43 \mathrm{~m}$ long, $2.44 \mathrm{~m}$ wide $(37-1 / 2 \mathrm{ft} 1 \mathrm{ong}, 8 \mathrm{ft}$ wide), and is of all-stee 1 construction. During shipment, the skid sits directly on the bed of a slightly modified standard 100-ton capacity flat car. During transport, the skid is restrained by a securing system designed to resist the peak loads anticipated under normal railroad conditions for the hydraulically-cushioned draft gear.

\section{CASK SUPPORTS}

The horizontally transported cask is supported in two locations, just below the closure flange by a saddle and at the cask base by a pivot cradle. 
The support saddle for the head end is welded directly to the skid frame. This U-shaped structure engages the cask at its upper 1 ifting rings. Hardened pins are inserted through the lifting rings to provide restraint of the head end of the cask in the vertical and lateral directions, and through the saddle ears to furnish axial restraint for the total cask weight. The pivot cradle, consisting of two pedestals which are welded directly to the skid frame, and a counterbalanced cradle supports the base of the cask. The cradle pivots between the pedestals on two trunnions.

\section{COOLING SYSTEM}

Cask cooling is accomplished using air, at a velocity of $14.3 \mathrm{~m} / \mathrm{s}$ (47 fps), directed perpendicular to the cask surface from four ducts, running the length of the cask and 90 degrees apart, bisecting the four quadrants. Cooling air is supplied by two blowers driven by air-cooled diesel engines.

Fuel tanks which are located in the skid, have a total capacity of $2.16 \mathrm{~m}^{3}$ (570 gal.). This quantity will permit the continuous running of both units for 10 days. Either one of the units is capable of supplying sufficient air to cool the cask surface.

Both blowers discharge into a common air plenum, which feeds the four axial ducts that cool the cask. If one blower fails, a gravity damper prevents a back-flow of air from the plenum. 


\section{APPENDIX C}

MECHANICAL FAILURE THRESHOLD ESTIMATES FOR REFERENCE SPENT FUEL RAIL CASK 
APPENDIX C

MECHANICAL FAILURE THRESHOLD ESTIMATES FOR

REFERENCE SPENT FUEL RAIL CASK

Current regulations for transporting spent reactor fuel place certain mechanical integrity requirements on cask behavior during postulated accident conditions. These requirements are specified in Reference 1. Requirements dealing with impact stipulate that casks must be capable of withstanding a $9.14 \mathrm{~m}(30-\mathrm{ft})$ free drop onto an essentially unyielding target in an orientation in which maximum damage would occur.

The actual impact failure threshold of various types of casks is largely unknown. In addition, the mode of impact failure and the response of cask contents are uncertain.

Recently full scale testing of commercial spent fuel casks has been performed in which severe accident situations were simulated (for example, see Reference 2). Results indicate that impact into real targets with impact velocities substantially greater than those occurring in a $9.14 \mathrm{~m}$ (30-ft) drop test can be absorbed without loss of containment.

The objective of the work described below was to make estimates of failure velocity and fuel response estimates for a reference rail cask meant to transport seven PWR fuel bundles. In performing these analyses, no consideration was given to:

- target compliance or energy absorption characteristics

- energy absorption due to other items in a cask system; e.g., tie downs, railcar, etc.

The effects of the above two items will no doubt tend to make the results somewhat conservative. The degree of this conservatism is not known, however. In addition, assumptions are made later for which the conservatism or lack of conservatism is uncertain. As a result, it is possible that predicted failure velocity thresholds could differ from actual values by perhaps as much as $50 \%$. 
However, a conservative approach was used which produced failure thresholds believed to be on the low side of values that might be experienced in actual accidents .

The reference spent fuel cask used in this analysis is described in Appendix B. The gross weight of the cask and contents is assumed to be $63,420 \mathrm{~kg}(140,000 \mathrm{lb})$ for structural analysis purposes. It is important to note that only the cask and contents are considered in this effort; tie downs, active cooling devices, mounting skids and the flat car were neglected. In addition, certain simplifying assumptions regarding cask geometry were made. The cask structural geometry used will be described with reference to Figures C. 1 through C. 4 .

As a protection against possible impact situations, the cask design includes sacrificial stainless steel fins that are designed to deform in a a predictable fashion during impact and thus absorb kinetic energy. Five fins of annular shape are positioned along the axis of the cask and are designed to absorb energy for side impacts. The central circumferential fin also serves as a divider of the neutron shield water jacket, thus providing two separate neutron shield annular regions. The outer member of the neutron shield is formed of corrugated sheet to enhance heat transfer.

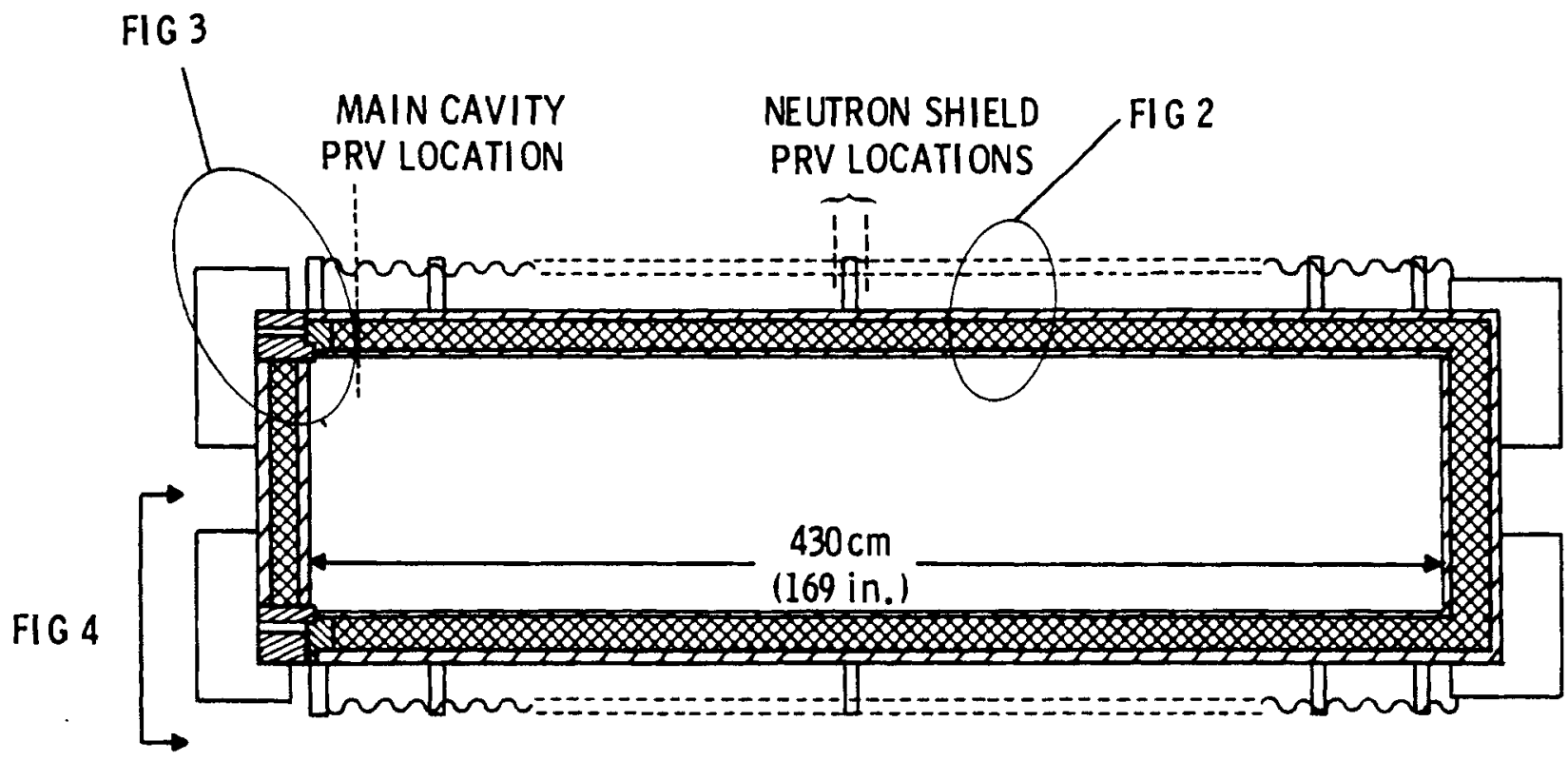

FIGURE C.1. Cask Closure End 


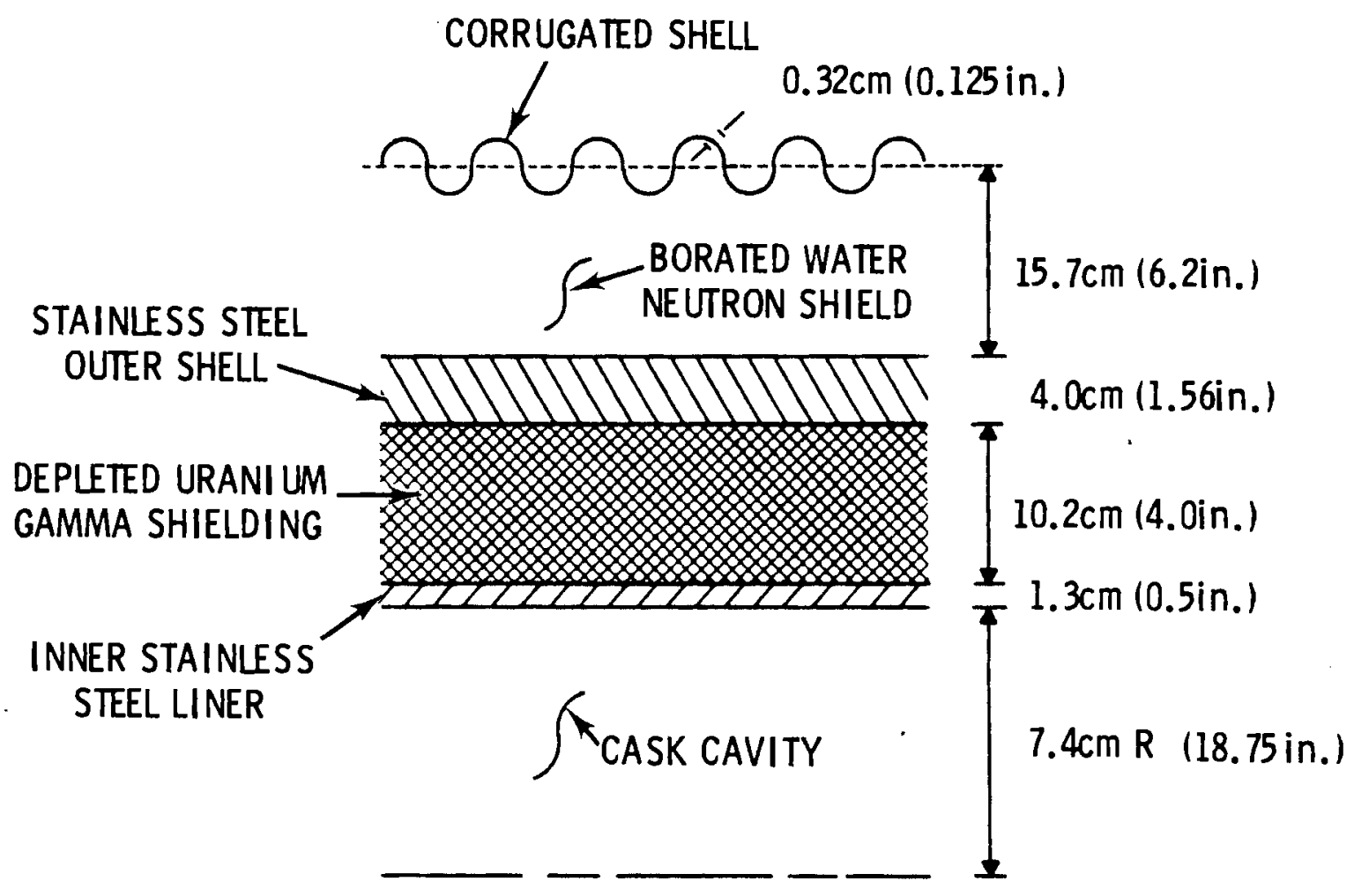

FIGURE C.2. Cask Wall Section

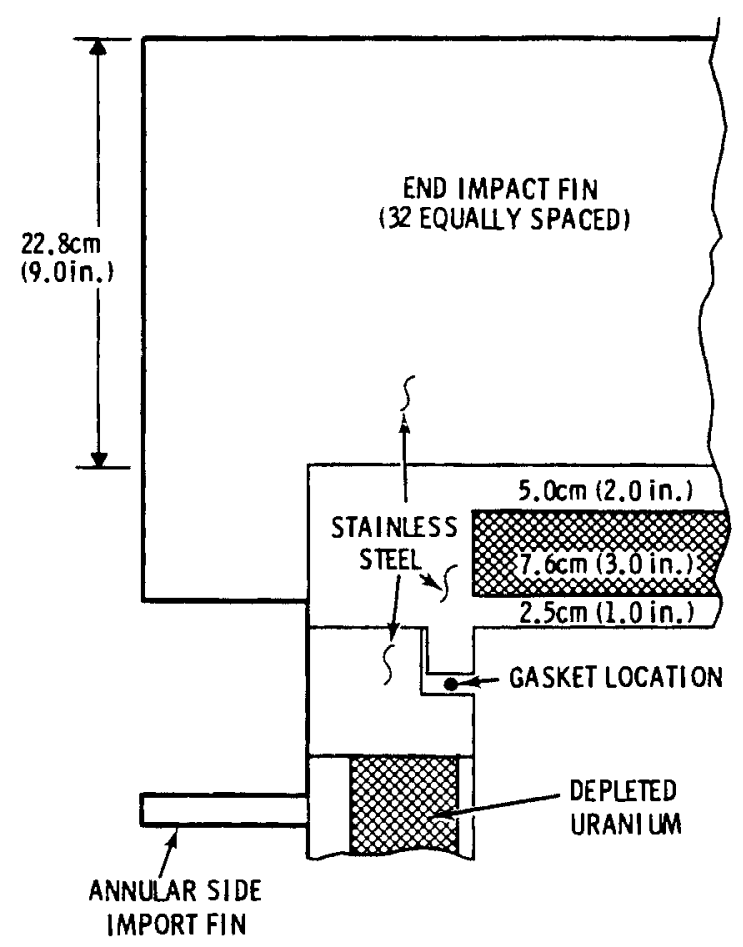

FIGURE C.3. Cask Closure End 


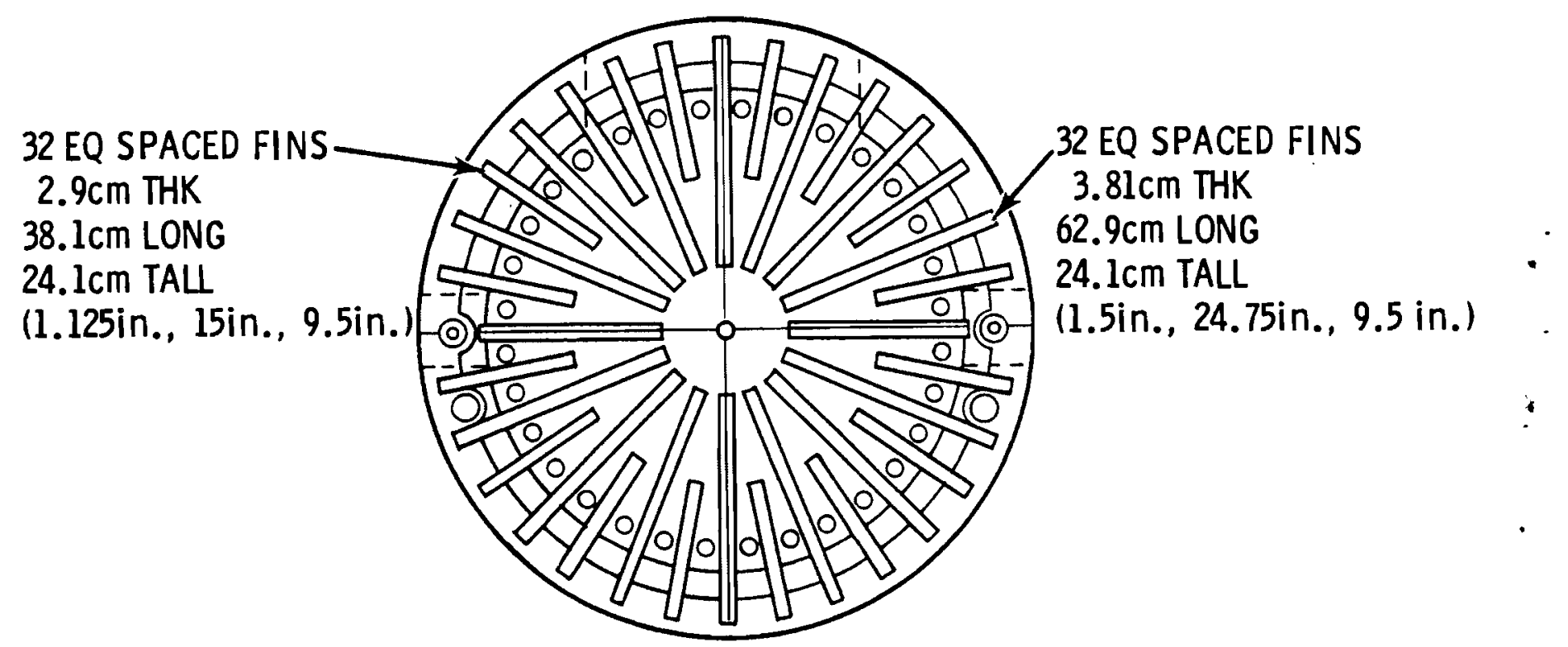

FIGURE C.4. View of End Impact Fins

Fins placed at each end of the cask are oriented radially and function as energy absorbers in the event of end axial impacts. The fin configurations are assumed identical for both the lid (top) end and the bottom ends of the cask. Each end has thirty-two fins at uniform angular spacing. On the top end, these fins are attached to the removable lid. Fins at the bottom end are permanently affixed to the cask body.

The cask wall and end construction both consist of three layers. Depleted uranium which serves as a gamma shield makes up the central thickness of these components. Inner and outer thicknesses are composed of stainless steel and are assumed to be unbonded from the depleted uranium. Dimensions of these various layers are shown in Figures C.2. through C.3.

The main cask cavity is designed to hold seven PWR fuel bundles. These bundles are supported by individual square insertion tubes which in turn are supported by nine axially spaced circular plates. This support/spacing system is shown in Figure C.5.

The neutron shield cavity and the cask main cavity are liquid filled during normal transport. To protect against over-pressurization, these 


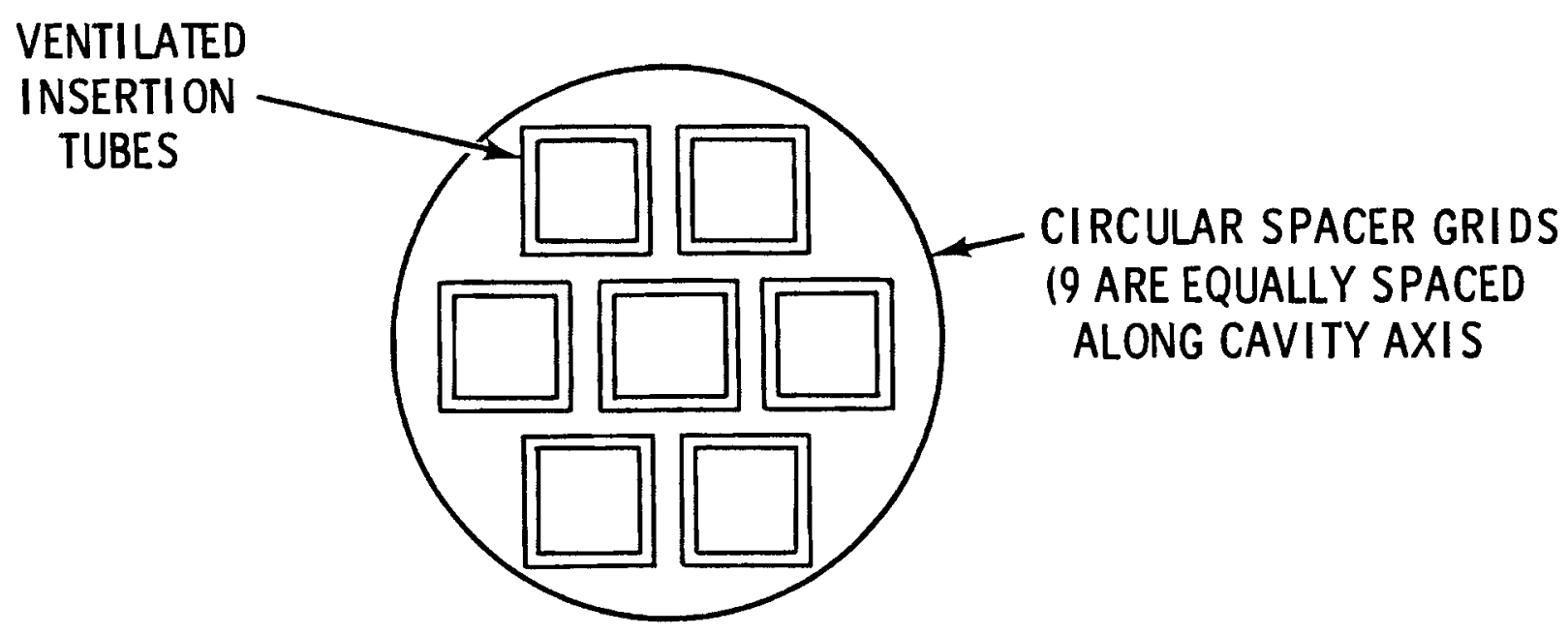

FIGURE C.5. Fuel Basket End View

portions of the cask are fitted with pressure relief valves (PRVs) which temporarily vent in the event of excess pressure and then re-seal after the pressure is relieved. The locations of these PRVs are illustrated in Figure C.1. Actuation pressures are:

- Cask Main Cavity

- Neutron Shield Compartments

$\frac{2.4 \mathrm{MPa} \text { (gage) }(350 \mathrm{psig})}{1.4 \mathrm{MPa} \text { (gage) }(200 \mathrm{psig})}$

These valves are assumed to be protected from impact effects by energy absorbing shielding designed to prevent their malfunction during or after impact.

Cask response estimates for end and side impact were each made in two analysis steps. In the first step, energy absorption of the crushable sacrificial fins was analyzed. In the second part of each analysis, the response of the cask body was modeled and analyzed by using the HONDO computer program. (3) During fin crushing, the cask body was assumed to experience negligible deformation. Later, during deformation of the cask body, the crushed sacrificial fins were assumed to be essentially rigid and all remaining energy was assumed to be absorbed by deformation of the main body of the cask. 
The study of energy absorption characteristics of metallic fins has been extensively investigated in Reference 4. In this reference, experiments are described in which energy absorption was correlated with various fin parameters. These parameters included fin geometry, static yield strength of the fin material, and fin crush deformation and orientation with respect to the impacting surface. The following sections describe the method used to calculate the various mechanical thresholds.

SPENT FUEL CASK FAILURE THRESHOLDS

Case 1 - End-on Impact Onto a Rigid Plane Target

Fin geometry for end impact absorption is shown in Figure C.4. For fins of this geometry, Reference 4 indicates that energy absorption is approximately:

$$
\begin{aligned}
E_{f} & =12 M_{p} \\
E_{f} & =\text { Fin deformation energy } \\
M_{p} & =\text { Fin plastic moment } \\
& =\sigma_{y} \frac{b t^{2}}{4} \\
\sigma_{y} & =\text { Material yield strength (static) } \\
b & =\text { Fin width } \\
t & =\text { Fin thickness }
\end{aligned}
$$

This expression represents energy absorbed by a net fin crush of approximately $50 \%$ during normal impact. This deformation fraction was assumed to represent a realistic estimate of fin energy absorption capability.

By making use of the fin geometries shown in Figure C.4 and the yield strength from Table C.1, the total energy absorption limit of the 32 lid impact fins for axial impact was estimated.

The estimated energy absorption for end-on impact was $10.6 \times 10^{6}$ joules $\left(9.4 \times 10^{7} \mathrm{in.} 1 \mathrm{bf}\right)$. As a matter of interest, this energy is equivalent to the following drop heights and impact velocities:

- Drop Heights

$55.7 \mathrm{ft}$

16.98 meters 
- Impact Velocity

$59.8 \mathrm{f} / \mathrm{s}$

$40.8 \mathrm{mph}$

$18.227 \mathrm{~m} / \mathrm{s}$

$65.6 \mathrm{~km} / \mathrm{hr}$

An estimate of this deceleration level can be made by assuming uniform deceleration over the crush depth of the fins.

$W N g \frac{h}{2}=$ energy absorption

$$
\begin{aligned}
W & =\text { cask weight } 1.77 \times 10^{5} \mathrm{nt}(140,000 \mathrm{lbf}) \\
\mathrm{h} & =\text { fin length } 24 \mathrm{~cm}(9.5 \mathrm{in.}) \\
\mathrm{N}_{\mathrm{g}} & =\text { g-leve } 1=141 \mathrm{gs}
\end{aligned}
$$

Behavior of the generic cask for end impact after the end fins have been crushed was analyzed by using the HONDO computer program. (3) A mesh plot of the finite element model is shown in Figure C.6. For the sake of economy, only the front portion of the cask was treated. The total mass of the cask and contents was accounted for by increasing the density of the top row of

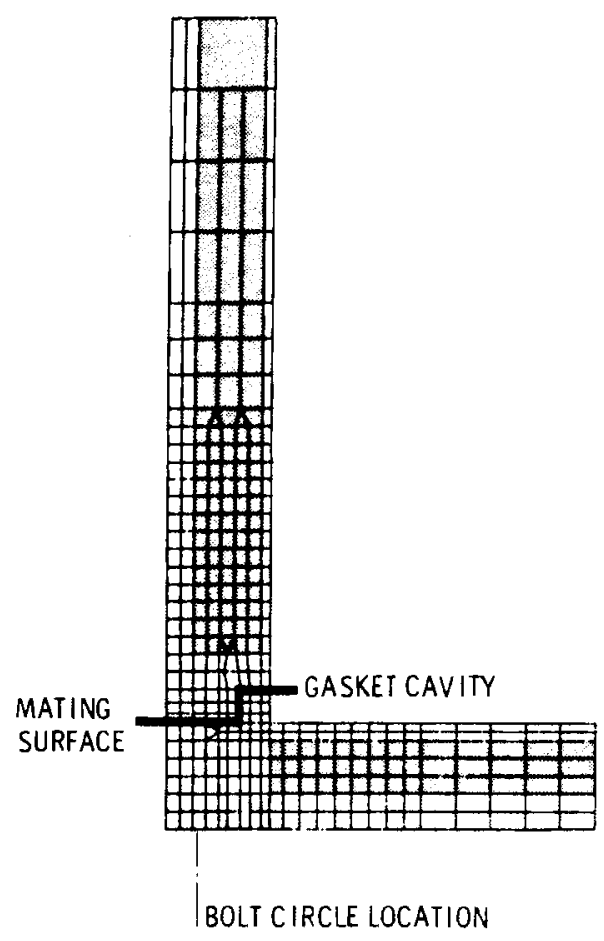

FIGURE C.6. HONDO Mesh Used for the End Impact Mode1 
elements shown in Figure C.6 so that the total model mass was $63,420 \mathrm{~kg}$ $(140,0001 \mathrm{bm})$. Care was taken in scaling both the stiffness and the density of these elements to maintain sonic velocities of a level similar to the other cask materials.

The "slide line" feature of HONDO was used extensively in this model. This allowed adjacent materials to separate and slide when in contact. The depleted uranium core (see Figure C.6) was allowed to slip at the interfaces of the stainless steel plates of the lid and cylindrical shells of the cask body.

In addition, the ring flange of the cask body was allowed to slide radially with respect to the lid. The gasket cavity was modeled by allowing the cask flange to penetrate through the gasket space and bear on the corresponding top surface of the lid.

Bolt preloading was simulated at the row of elements in the vicinity of the bolt circle. Relative axial motion between the cask flange and the lid was restrained by appropriate stiffness. At no time during the impact simulations did the two surfaces separate axially and attempt to plastically deform in the bolting material in tension.

Both the depleted uranium and the stainless steel portions of this model made use of the finite strain, elastic-plastic strain hardening material characterization of HONDO. (Material model six was used.) Pertinent material properties utilized for these materials are summarized in Table C.1.

Impact analyses were performed for three velocities--48.3, 64.4, 80.5 km/hr $(30,40$ and $50 \mathrm{mph})$. These velocities represent the velocity remaining after the lid impact fins have been crushed. Final deformed shapes for these impact velocities are shown in Figures C.7 through C.9.

Primary concern in interpreting these analyses focused on:

- The relative radial motion between the 1 id flange and the ring flange in the vicinity of the bolt circle.

- The strain in the vicinity of the gasket location.

These values are shown in Figures $\mathrm{C.10}$ and $\mathrm{C} .11$. 
TABLE C.1. Mechanical Material Properties

End Fins:

Yield Strength

Density

$206.8 \mathrm{MPa}$
$7,833 \mathrm{~kg} / \mathrm{m}^{3}$

$(30,000 \mathrm{psi})$

$\left(0.283 \mathrm{lbm} / \mathrm{in.}^{3}\right)$

Circumferential Fins:

Yield Strength

Density

$413.7 \mathrm{MPa}$
$7,833 \mathrm{~kg} / \mathrm{m}^{3}$

$(60,000 \mathrm{psi})$

$\left(0.2831 \mathrm{bm} / \mathrm{in.}^{3}\right)$

Flange \& Lid:

Young's Modulus

Density

Poisson's Ratio

$\begin{array}{cc}1.93 \times 10^{5} \mathrm{MPa} & \left(29 \times 10^{6} \mathrm{psi}\right) \\ 7,833 \mathrm{~kg} / \mathrm{m}^{3} & \left(0.283 \mathrm{lbm} / \mathrm{in}^{3}\right)\end{array}$

Yield Stress

Hardening Modulus

0.3

HONDO Strain Rate Parameters

$P$

D

$227.5 \mathrm{MPa}$

$1.378 \times 10^{3} \mathrm{MPa}$

$(33,000 \mathrm{psi})$

$\left(2 \times 10^{5} \mathrm{psi}\right)$

6.01

$5.73 \times 10^{5}$

Kinimatic Hardening Assumed

Depleted Uranium:

Young's Modulus

Density

Poisson's Ratio

Yield Stress

$2.05 \times 10^{5} \mathrm{MPa}$

$1.87 \times 10^{4} \mathrm{~kg} / \mathrm{m}^{3}$

0.23

$142 \mathrm{MPa}$ $\left(29.8 \times 10^{6} \mathrm{psi}\right)$

$\left(0.678 \mathrm{lbm} /\right.$ in. $\left.^{3}\right)$

$(20,600$ psi)

No Strain Rate Consideration

Kinematic Hardening Assumed

A bulge occurs in the inner shell above the cask ring flange. While this bulge most likely reflects a real tendency of the inner shell to buckle, the numerical accuracy of the prediction is questionable due to a lack of mesh refinement in that region. While being quite noticeable, it is felt that little significance should be attributed to large model strain in the vicinity. Additional mesh refinement in the thickness direction for this shell would have resulted in excessive computational expense and was judged to be unwarranted for the current objective. 


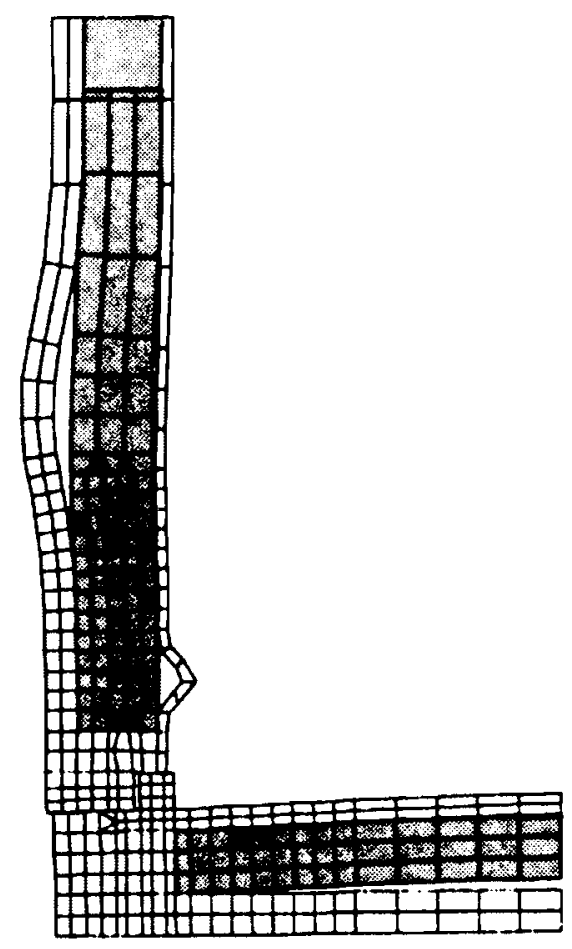

FIGURE C.7. End Deformation After 48.3-km/hr (30-mph) Impact. (impact rings neglected)

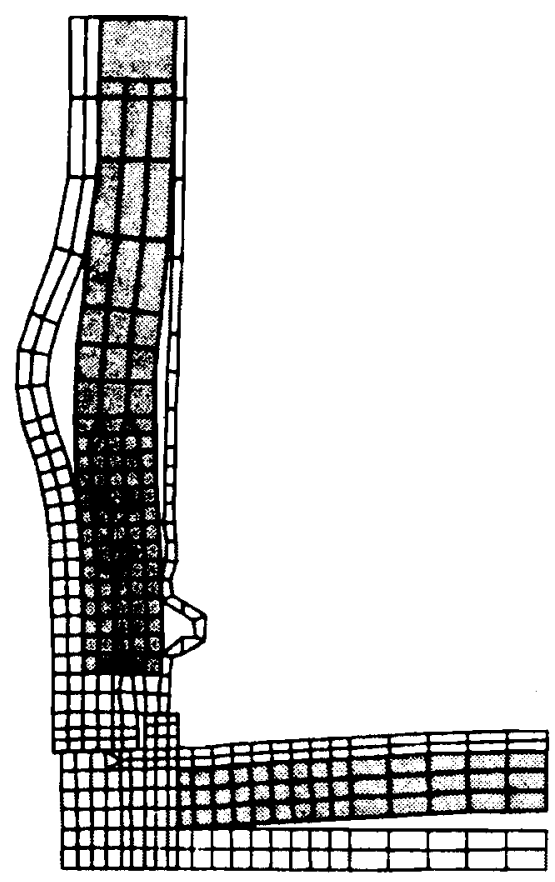

FIGURE C.8. End Deformation After 64.4-km/hr (40-mph) Impact. (impact fins neglected) 


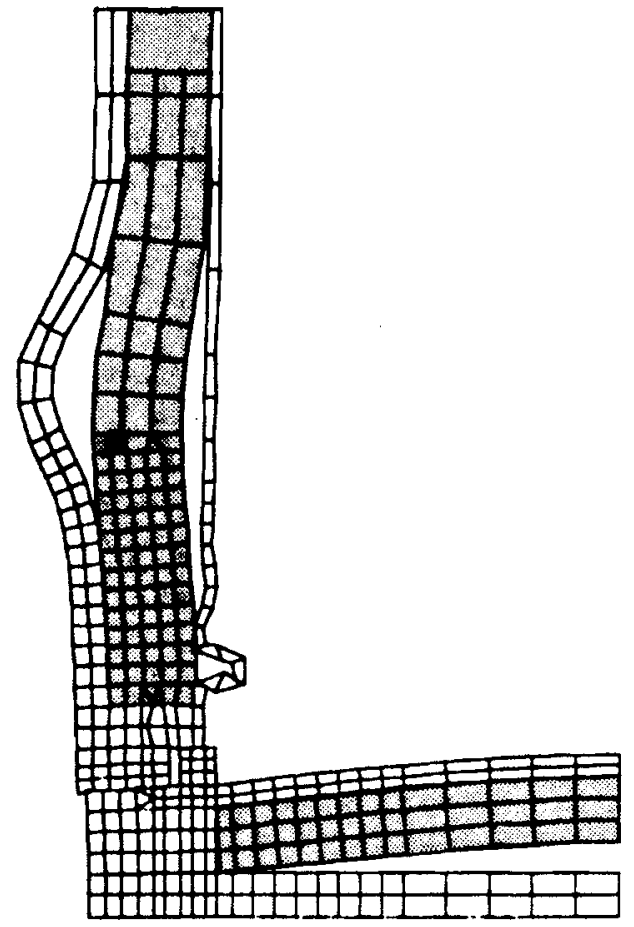

FIGURE C.9. End Deformation After $80.5-\mathrm{km} / \mathrm{hr}$ (50-mph) Impact. (impact firs neglected)

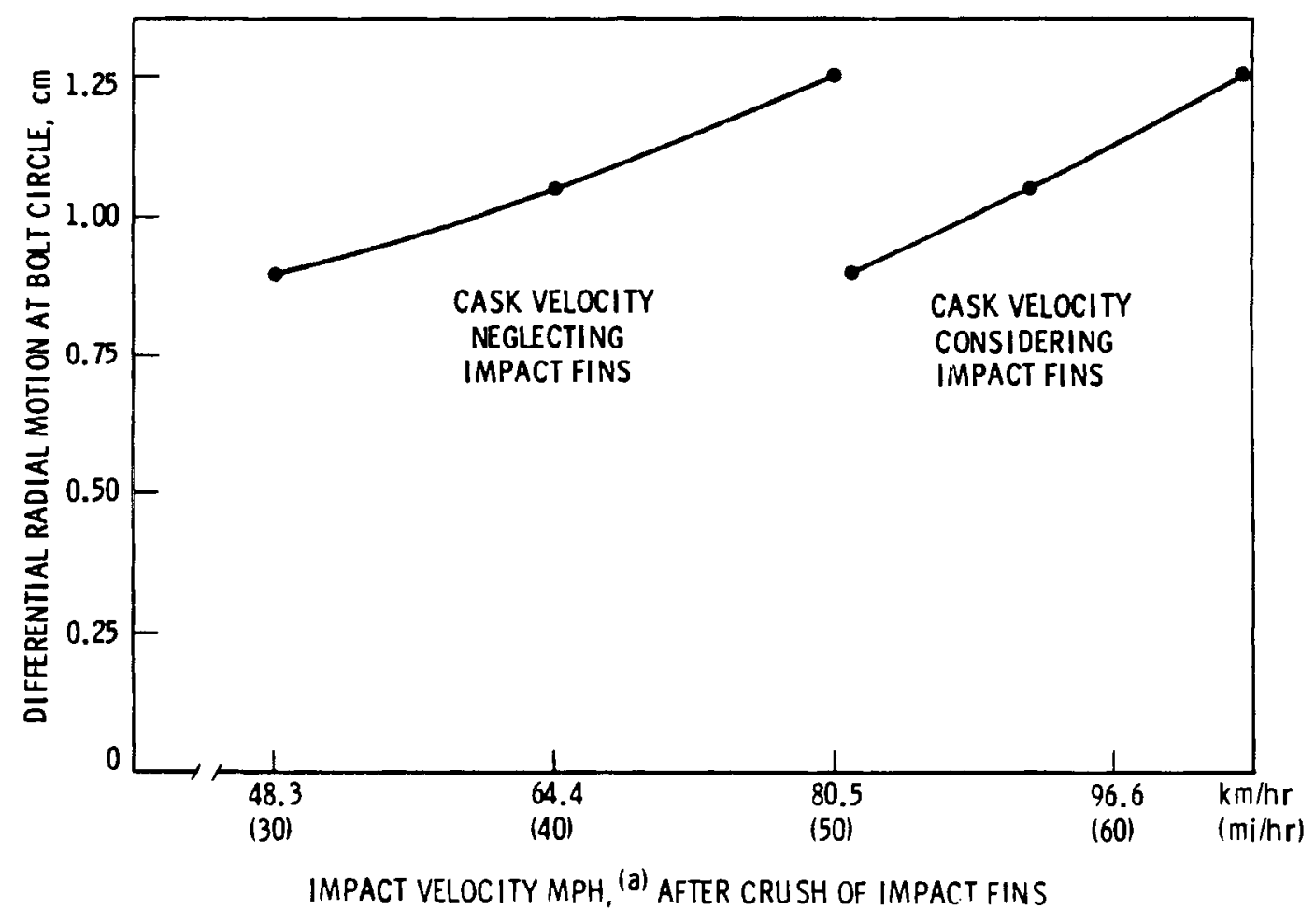

FIGURE C.10. Lid Bolt Shear Motion for End Impact

(a) $\mathrm{MPH} \times 1.61=\mathrm{km} / \mathrm{hr}$ 


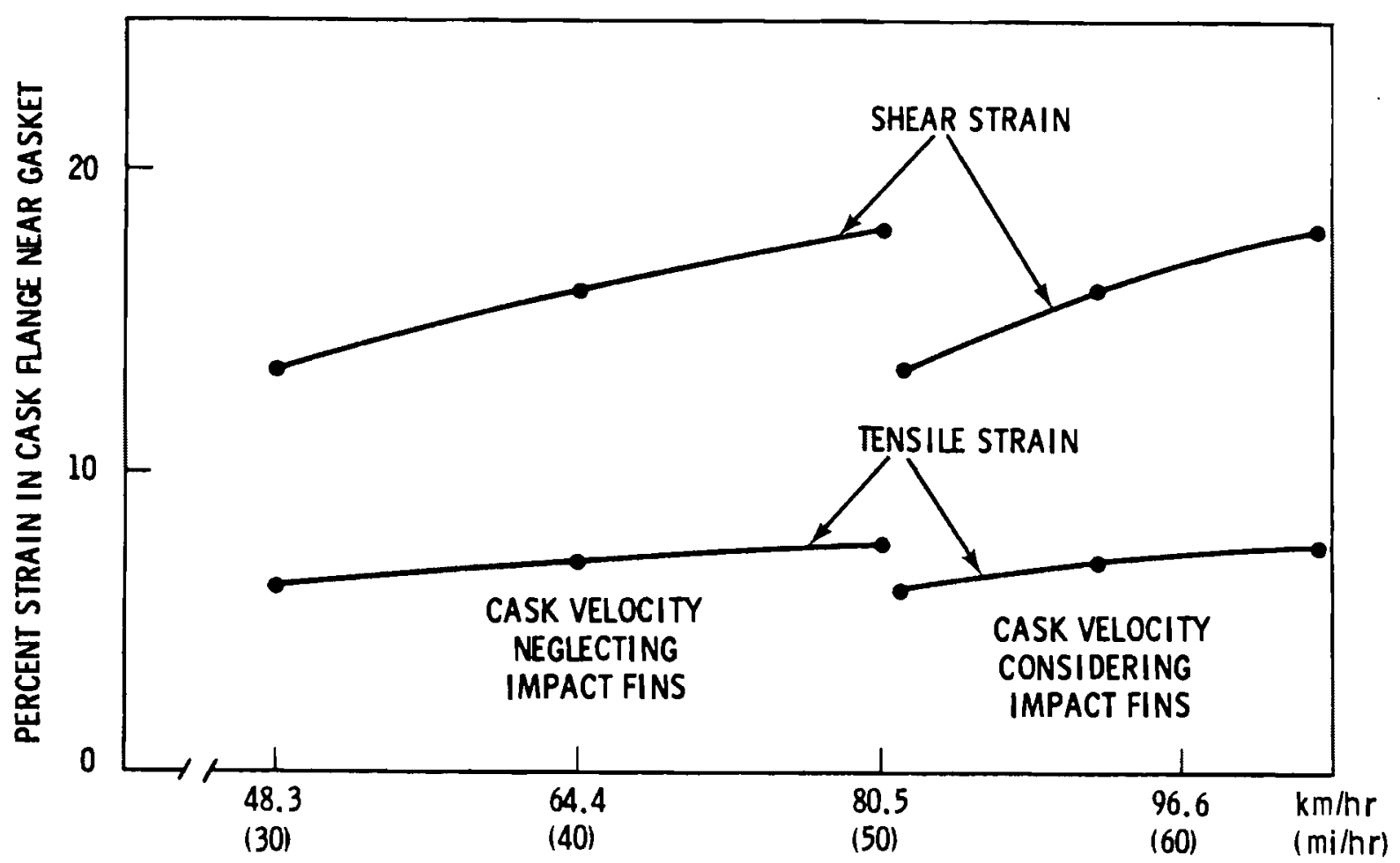

IMPACT VELOCITY

FIGURE C.11. Cask Flange Strain in the Gasket Vicinity as a Function of Impact Velocity

Selection of a specific cask failure velocity for end impact (including impact limiters) is difficult. Based on the results shown in Figures C.10 and $\mathrm{C} .11,81 \mathrm{~km} / \mathrm{hr}(50 \mathrm{mph})$ would appear to be a reasonable failure limit.

\section{Case 2 - Side Impact on Planar Surface}

Analysis of side impact of the cask was performed in a manner analogous to the end impact case. During initial impact phases, energy was assumed to be absorbed by the sacrificial annular impact limiters. Further investigations were performed with the HONDO computer program to study deformation of the cask body.

Investigation of annular fins for side impact was performed in a manner similar to that used for end impact. For this case, the plastic hinge was assumed to occur at the inside radii of the annular plates (see Figure C.12). Using the same methods as were used in the end impact calculations, the absorbed energy, equivalent drop height, impact velocity, and deceleration values were found to be: 


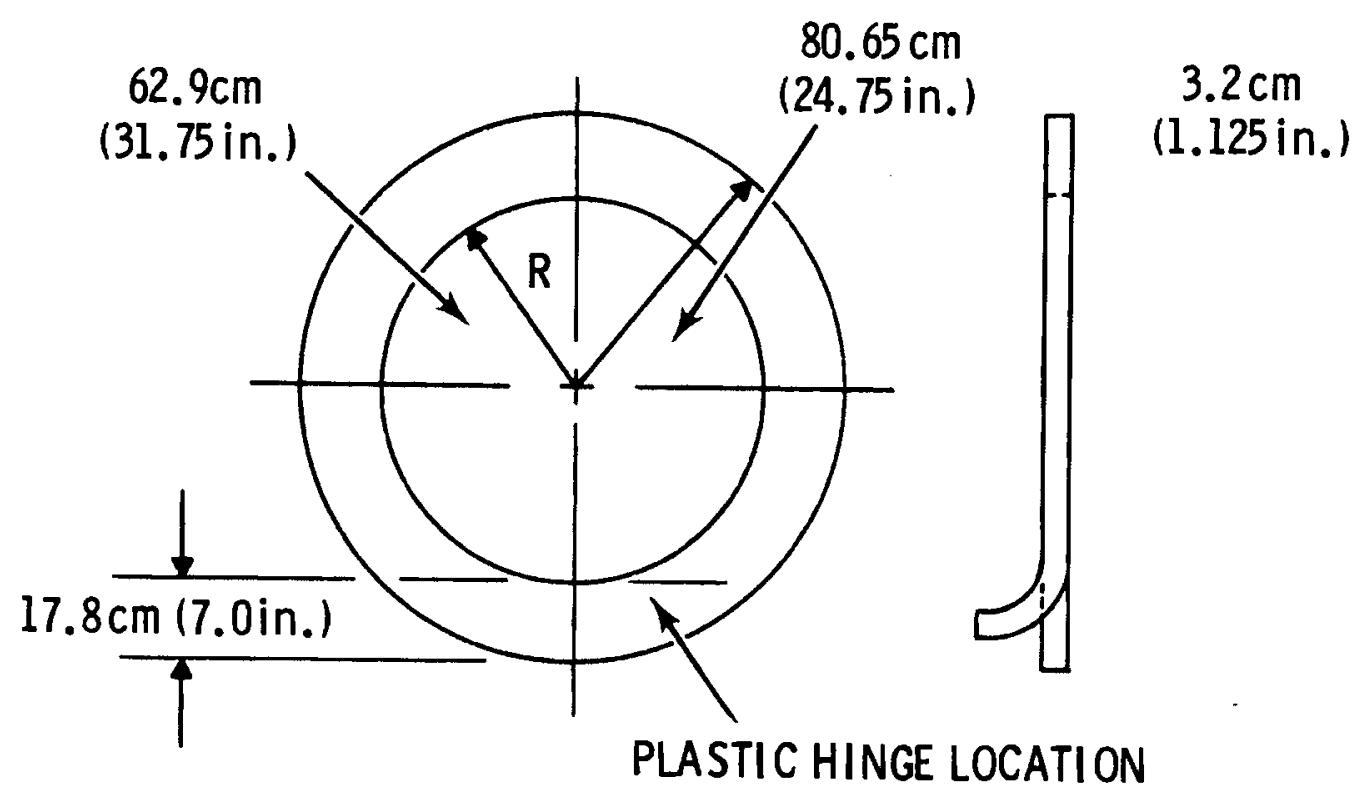

FIGURE C.12. Annular Side-Impact Ring

- Energy absorbed: $6.3 \times 10^{6} \mathrm{~J}\left(5.592 \times 10^{7}\right.$ in $\left.1 \mathrm{bf}\right)$

- Equivalent drop height

$33.3 \mathrm{ft}$

$10.1 \mathrm{~m}$

- Impact velocity

$46.3 \mathrm{ft} / \mathrm{sec}$

$31.5 \mathrm{mph}$

$14.1 \mathrm{~m} / \mathrm{s}$

- Deceleration rate

$115 \mathrm{gs}$

A plane strain HONDO model was used to study cask deformation behavior of the thick uranium shell and the two stainless steel shells comprising the cask main wall. The end stiffening effects of the lid and bottom members were not modeled. Thus, deformation response of the computer model will have to be interpreted as being the response of a "typical" section through the middle of the cask. The computer model overpredicts deformation near the lid and bottom ends. 
The mesh layout used is shown in Figure C.13. As was the case with the end-impact analysis, the "slide line" feature of HONDO was utilized to allow sliding contact (or voids) between the uranium shielding and the stainless steel shells. Material parameters used for this model were those used in the end-impact case and are shown in Table C.l.

Deformation plots for the side impact case are shown in Figures C.14 through C.16. In order to characterize gross deformation as a function of impact velocity, changes in model diameter (both horizontal and vertical) were chosen as parameters. These plots are shown in Figure C.17. In addition, maximum tensile strain in each material is plotted in Figure C.18.

As a measure of cask integrity for side impact, it was decided to allow one wall thickness of deformation as a failure threshold. This criteria yields an impact velocity of $75.8 \mathrm{~km} / \mathrm{hr}(47 \mathrm{mph})$.

\section{Case 3 - Side Impact on Non-Planar Target}

It is assumed that cask targets are flat and rigid whereas certain targets in the real world are smaller than the cask. A bridge abutment or a tunnel entrance for example could pose a more serious threat (the cask would have a lower failure velocity) than a flat target. Such a target would impose localized damage for side impact. As an approximation, it was assumed that this localized region would be approximately the diameter of the outer stainless steel jacket (126 cm, 49.62 in.) in expanse.

Assuming uniform cask weight per unit length, the side impact HONDO analyses may be scaled to approximate the energy absorbed by impacting a non-flat target described. Utilizing this concept and assuming one wall thickness of deformation as a failure threshold:

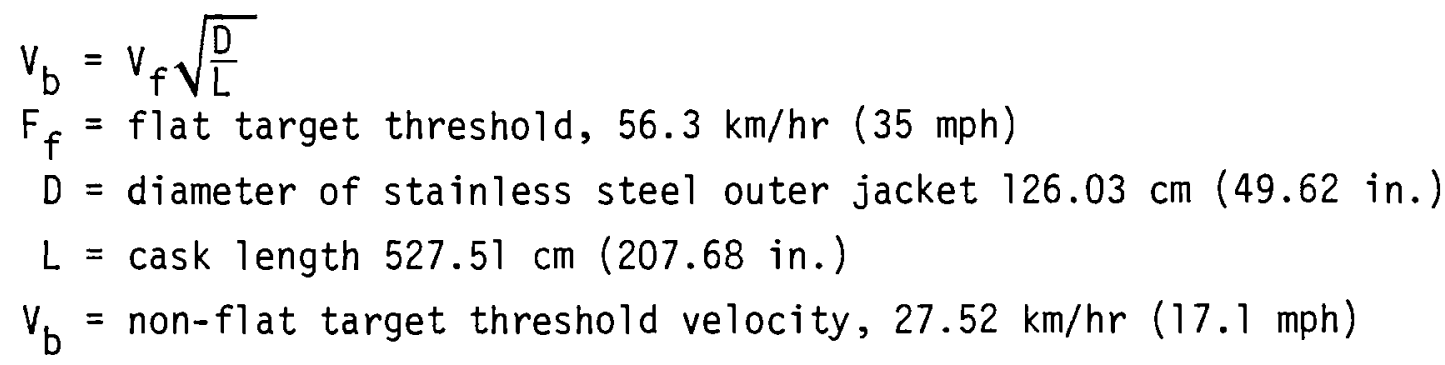




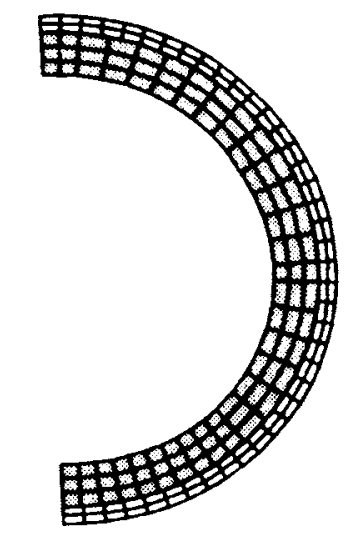

FIGURE C.13. HONDO Mesh Used for the Side-Impact Model

$\stackrel{?}{\dot{b}}$

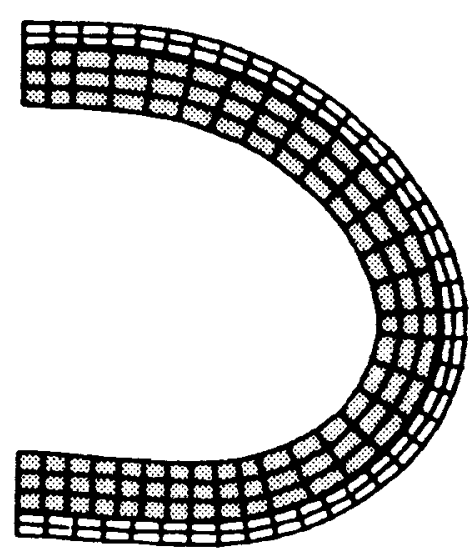

FIGURE C.15. Side Deformation After $96.6-\mathrm{km} / \mathrm{hr}$ (60-mph) Impact. (Annular impact fins neglected.)

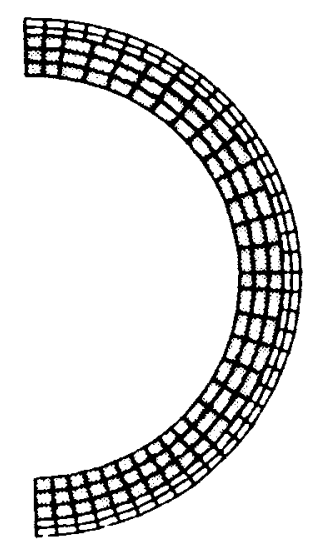

FIGURE C.14. Side Deformation After $32.2-\mathrm{km} / \mathrm{hr}$ (20-mph) Impact. (Annular impact fins neglected.)

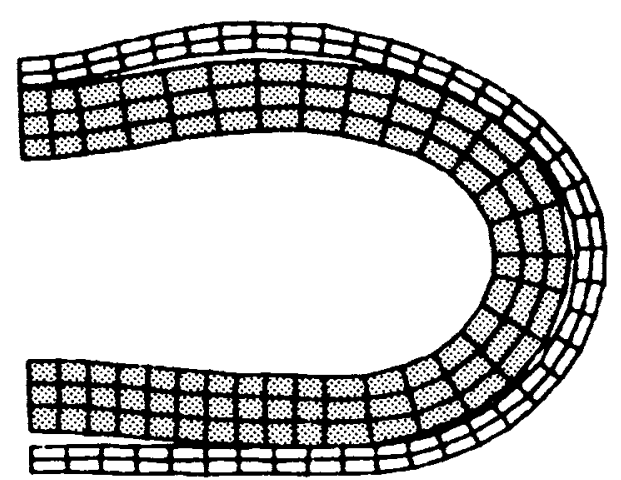

FIGURE C.16. Side Deformation After 144.8-km/hr (90-mph) Impact. (Annular impact fins neglected.) 


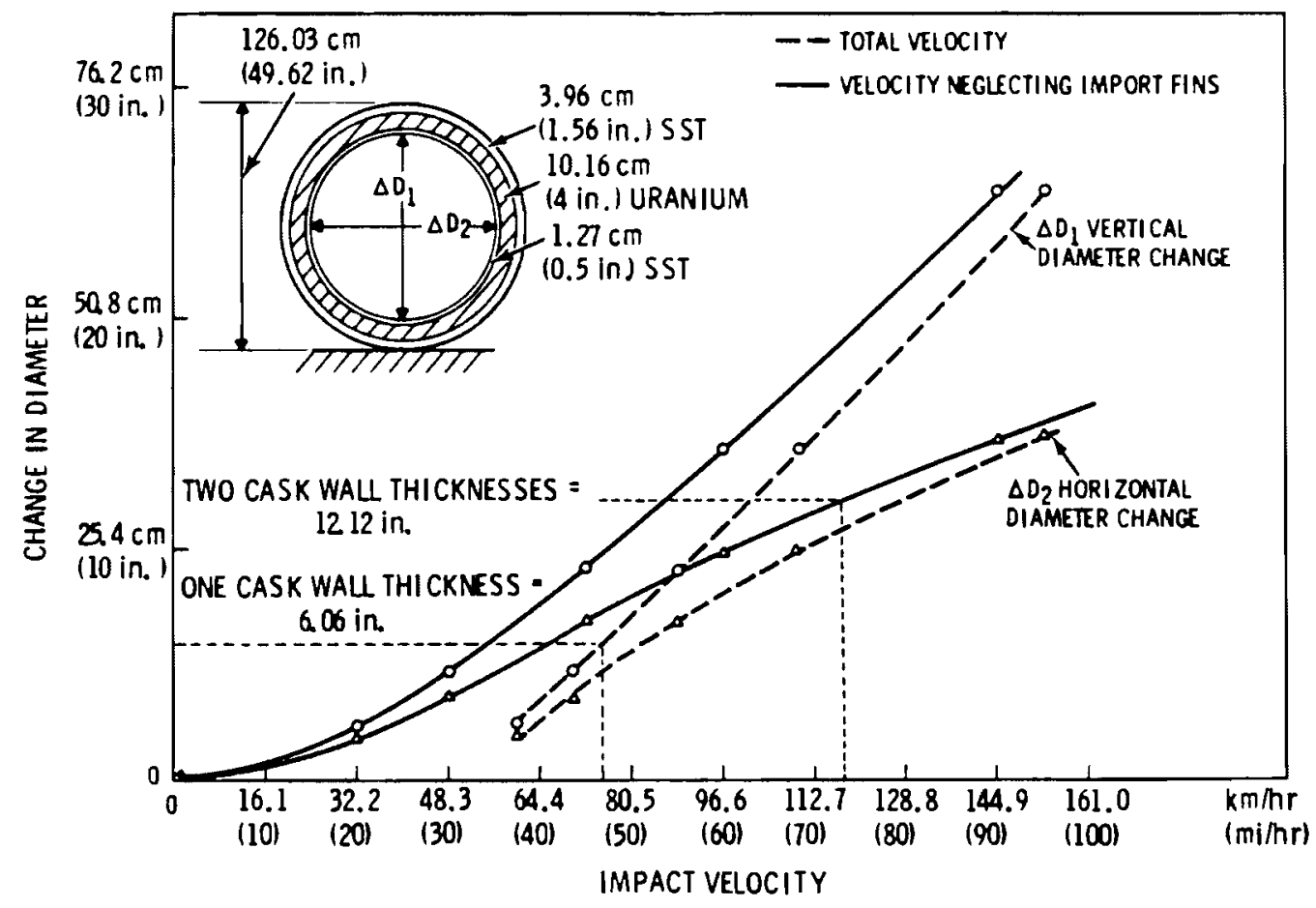

FIGURE C.17. Change in Cask Diameter versus Side Impact Velocity

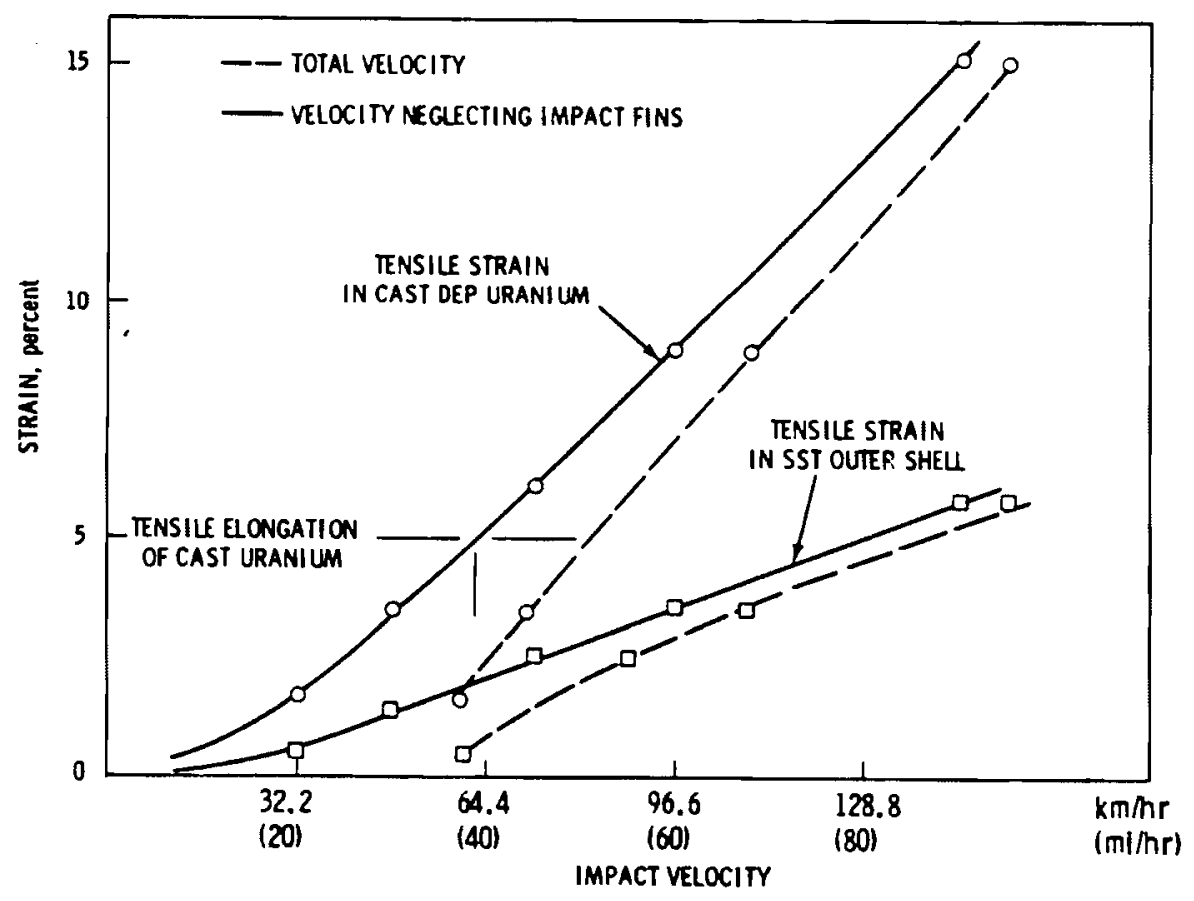

FIGURE C.18. Component Strain versus Side Impact Velocity 
Case 4 - Pressure Relief Valve Behavior During Impact

Pressure relief valves protect both the outer neutron shield and the cask main cavity from over-pressurizations, primarily from fire environments. The valves are designed to reseat after pressure relief and thus prevent further loss of contents. During the sudden deceleration of impact, pressure buildup could conceivably actuate these devices with subsequent partial loss of fluid contents. The amount of lost fluid will depend largely on the degree of ful1ness of the compartments. For only partially full compartments, pressure buildup will no doubt be more gradual than for full compartments, since fluid will have to surge forward in order to reach the top mounted PRVs (see Figure C.1).

For purposes of this analysis, the conservative assumption was made that both the neutron shield and cask main cavity were full of fluid. Thus the necessary impact velocity required to actuate the PRVs is likely to be substantially greater than the values calculated here.

It was conservatively assumed that the deceleration of the cask was an instantaneous event and that pressure buildup was caused by the water hammer effect.

For the main cavity, the PRV is set to actuate at $2.41 \mathrm{MPa}$ (gage) (350 psig). Operating pressure in the cavity is assumed to be $0.38 \mathrm{MPa}$ (gage) (55 psig). Thus, additional pressure required to actuate the valve is $2.03 \mathrm{MPa}$ (gage) (295 psig). The instantaneous velocity change needed to cause this pressure is: ${ }^{(5)}$

$$
\begin{aligned}
\Delta V & =C \frac{\Delta P}{E V} \\
\Delta P & =\text { pressure change } 2.03 \mathrm{MPa} \\
C & =\text { sonic velocity in water } 1.43 \times 10^{2} \frac{\mathrm{m}}{\mathrm{sec}}(4,700 \mathrm{ft} / \mathrm{sec}) \\
E \nu & =\text { bulk modulus of water } 2.2 \times 10^{2} \mathrm{MPa}(320,000 \mathrm{psi}) \\
\Delta V & =1.32 \mathrm{~m} / \mathrm{s}(4.3 \mathrm{f} / \mathrm{s})
\end{aligned}
$$

For the neutron shield, the PRV is set to actuate at $1.38 \mathrm{MPa}$ (gage) (200 psig). The operating pressure is $0.04 \mathrm{MPa}$ (gage) (5 psig). Therefore, $1.34 \mathrm{MPa}$ (gage) (195 psig) additional pressure is required for PRV actuation. 
The neutron shield shell is much more flexible than the cask wall and the assumption of rigid walls no longer holds. Reference 5 gives the following expression to account for compliant ducts.

$$
\begin{aligned}
\Delta P= & C_{\text {eq }} \frac{E v}{C^{2}} \Delta \nu \\
C_{\text {eq }}= & 1+\frac{E \nu D}{E t}{ }^{-\frac{1}{2}} \mathrm{C} \\
E= & \text { modulus of elasticity of shel1 material } 2.06 \times 10^{5} \mathrm{MPa}\left(30 \times 10^{6} \mathrm{psi}\right) \\
D= & \text { diameter of she11 } 157.5 \mathrm{~cm}(62 \mathrm{in.}) \\
t= & \text { shel1 thickness } 0.317 \mathrm{~cm}(0.125 \mathrm{in.}) \text { (Twice this value was used } \\
& \text { to account for the effects of the corrugated surface.) }
\end{aligned}
$$

Using these expressions, the instantaneous velocity change necessary to actuate the neutron shield PRV was found to be $1.65 \mathrm{~m} / \mathrm{s}(5.4 \mathrm{f} / \mathrm{s})$.

These actuation threshold velocities are quite low. Investigation assuming uniform deceleration rates caused by the absorber fin deformations revealed that these g levels are sufficient to cause actuation for the lengths of water columns involved. Thus any non-instantaneous impact situations in which absorber fins are appreciably deformed will cause the valves to actuate, and some loss of fluid will occur before reseating.

Case 5 - Fuel Behavior During Impact

The fuel bundle geometry chosen for this study was taken from Reference 6 . The bundle contains a $17 \times 17$ array of pins. Pertinent fue 1 pin information relating to structural analysis and the notation used is listed in Table C.2.

For side impact, stress levels induced in the fuel cladding are caused by internal gas pressure and inertial loading due to deceleration. It was conservatively assumed that fuel pellets carried none of the flexure loading arising from inertial effects.

The maximum shear stress in the cladding material under this condition is:

$$
2 \tau_{\max }=\frac{P d_{i}}{d_{0}-d_{i}}+\frac{N g \omega l^{2}}{12}
$$


TABLE C.2. Fue1 Pin Data

$\begin{array}{llcc}\mathrm{L} & \text { Length } & 383.5 \mathrm{~cm} & 151 \mathrm{in} . \\ \mathrm{d}_{0} & \text { OD } & 0.950 \mathrm{~cm} & 0.374 \mathrm{in} . \\ \mathrm{d}_{\mathrm{i}} & \text { ID } & 0.835 \mathrm{~cm} & 0.329 \mathrm{in} . \\ \omega & \text { (wt/unit length) } & 6.55153 \frac{\mathrm{nt}}{\mathrm{m}} & 0.03744 \mathrm{bf} / \mathrm{in} . \\ \ell & \text { Grid Spacer Dimension } & 52.32 \mathrm{~cm} & 20.6 \mathrm{in} . \\ \mathrm{P} & \text { Internal Gas Pressure } & 8.038 \mathrm{MPa} & 1,167 \mathrm{psi} \\ \mathrm{I} & \text { Moment of Inertia of Tube } & 1.59 \times 10^{-2} \mathrm{~cm}^{4} & 3.83 \times 10^{-4} \mathrm{in}^{4} \\ \mathrm{E}_{\mathrm{Cl}} & \text { Cladding Modulus of Elasticity } & 8.9544 \times 10^{4} \mathrm{MPa} & 13 \times 10^{6} \mathrm{psi} \\ \sigma_{\mathrm{ult}} & \text { Ultimate Cladding Stress } & 6.199 \times 10^{2} \mathrm{MPa} & 90,000 \mathrm{psi}\end{array}$

For irradiated zircaloy cladding, Reference 7 gives $3.09 \times 10^{2} \mathrm{MPa}$ (45 psi) as a typical shear stress limit. Using this value and the preceding expression, it was found that $133 \mathrm{~g}$ 's was required to reach the critical stress level.

The actual $\mathrm{g}$ level imposed on a fuel pin during side impact is difficult to estimate. The deceleration rate imposed on the overall cask was computed to be $114 \mathrm{~g}$ 's. This is the $\mathrm{g}$ level caused by the crush forces of the side impact limiter fins. It seems reasonable to assume that at least some motion of the fue 1 pins relative to the cask she 11 will occur during impact. This would be due to flexural motion of the fuel pins themselves as well as possibly some deformation of the spacer plates supporting the fuel bundles. For this reason, the $\mathrm{g}$ level imposed on the fuel pins is probably less than $114 \mathrm{~g}$ 's.

As a conservative estimate of cask side impact velocity required to cause fuel failure, the impact velocity required to crush the side rings $(14.1 \mathrm{~m} / \mathrm{s}$, $46.3 \mathrm{f} / \mathrm{s}, 31.5 \mathrm{mph}$ ) wil1 be assumed. After the side impact rings have been crushed, g levels are likely to increase markedly. Therefore, $14.1 \mathrm{~m} / \mathrm{s}$ seems to provide a realistic estimate of side impact fuel failure.

Fue 1 response for end-on cask impact will depend largely on the deviation from straightness of the fuel pins and the structural features of the fuel pin end caps. If the pins are not sufficiently straight, then a good deal of fue 1 failure can be anticipated due to buckling. If end caps have sloped sides, then tube splitting is likely to occur. For the present objectives, however, 
consideration of these items is not possible. Stable behavior will be assumed, and tube splitting will be neglected. Thus, results could potentially be nonconservative.

Stresses caused by the following loadings were considered for analys is of fuel fin behavior during end impact:

- Stresses caused by internal gas pressure. Axial and circumferential stresses for this loading are:

$$
\begin{aligned}
& \sigma_{c}=\frac{P d_{i}}{d_{0}-d_{i}} \text { (tensile) } \\
& \sigma_{a}=\frac{P d_{i}}{2\left(d_{0}-d_{j}\right)} \text { (tensile) }
\end{aligned}
$$

- Stresses caused by constant deceleration during fin crushing. This is compressive axial stress which varies along the length of the pin: being a maximum at the impacting end, the zero at the trailing end. A conservative estimate for the stress at the impacted end can be made by neglecting fuel pellet stiffness. If this is done:

$$
\begin{aligned}
& \sigma_{a}^{1}=\frac{4 \omega L \mathrm{Lg}}{\pi\left(d_{0}{ }^{2}-d_{i}{ }^{2}\right)} \text { (compressive) } \\
& N_{g}=141
\end{aligned}
$$

- Traveling wave caused by an instantaneous velocity change assumed to occur when the fins are completely crushed. This stress was computed by neglecting fuel pellet stiffness.

$$
\begin{aligned}
& \sigma_{a}^{\prime \prime}=\Delta V \sqrt{E \rho_{\text {eq }}} \text { (compressive) } \\
& \rho_{\text {eq }}=\frac{4 \omega}{g \pi\left(d_{0}{ }^{2}-d_{i}{ }^{2}\right)}
\end{aligned}
$$


Assuming the ultimate stress for cladding material listed in Table C.3 and assuming that failure is caused by shear stress, the instantaneous velocity change required for fuel pin failure can be obtained by solving the following equation:

$$
\begin{aligned}
\frac{\left.\sigma_{u}\right\rceil t}{2} & =\left\|\sigma_{c}-\left[\sigma_{a}-\sigma_{a}^{1}-\sigma_{a}^{\prime \prime}\right]\right\| \\
\Delta V & =1.212 \mathrm{~m} / \mathrm{s}
\end{aligned}
$$

Thus, the cask velocity for fuel failure during end impact is just slightly in excess of that initial cask velocity to consume the impact fins. The cask velocity required to fail the fuel during impact can be determined by using the following expression:

$$
\begin{aligned}
V_{i}^{2} & =V_{\text {fin }}^{2}+\Delta V^{2} \\
v_{\text {fin }} & =18.22 \mathrm{~m} / \mathrm{s} \text { from previous calculations } \\
\Delta V & =1.212 \mathrm{~m} / \mathrm{s} \\
V_{i} & =18.26 \mathrm{~m} / \mathrm{s}(65.756 \mathrm{~km} / \mathrm{hr}, 40.86 \mathrm{mph})
\end{aligned}
$$




\section{REFERENCES}

1. Code of Federal Regulations. Title 10, part 71, Appendix B.

2. M. Heurta, Analysis, Scale Modeling, and Full Scale Tests of a Truck Spent-Nuclear-Fuel Shipping System in High Velocity Impacts Against a Rigid Barrier. SAND77-0270, Sandia Laboratories, Albuquerque, New Mexico, 1978.

3. S. W. Key, HONDO, A Finite Element Computer Program for the Large Deformation Dynamic Response of Axisymmetric Solids. SLA-74-0039, Savannah River Laboratory.

4. "Structural Analys is of Shipping Casks." Energy Absorption Capabilities of Plastically Deformed Struts Under Specified Impact Landing Conditions. ORNL-TM 1312, Vol. 9, Oak Ridge National Laboratory, Oak Ridge, Tennessee, February 1971.

5. J. W. Daily and D. F. Harleman, Fluid Dynamics. McGraw Hill, 1966.

6. Wisconsin Utilities Project. PSAR, Vol. 2, 1975.

7. P. J. Pankaskie, Irradiation Effects on the Mechanical Properties of Zirconium and Dilute Zirconium Alloys, A Review. BNWL-SA-618, Pacific Northwest Laboratory, Richland, Washington, 1976. 
APPENDIX D

THERMAL ANALYSIS OF REFERENCE

SPENT FUEL RAIL CASK 
APPENDIX D

\section{THERMAL ANALYSIS OF REFERENCE SPENT FUEL RAIL CASK}

The transient thermal behavior of the reference spent fuel cask, containing seven spent PWR bundles during various postulated accident conditions, is summarized in the appendix.

The objectives of this study were to determine the transient behavior of the cask and its spent fuel assemblies during and after several fire and lossof-cavity coolant situations. Transient maximum fuel and cask component temperatures were obtained from the analysis in order to permit estimation of failure sequences and releases of radionuclides. Postulated conditions presented here are in excess of cask licensing requirements.

A description of the general configuration, dimensions, and materials of the reference spent fuel shipping cask are given in Appendix B. A schematic of the cross-section of the shipping cask with fuel assemblies in place is shown in Figure B.1. The fuel assemblies selected for use in this analysis are of current design, with total heat generation rate for short-cooled (180-day) fuel of $8.5 \mathrm{~kW}$ per assembly, which is considered to be uniformly distributed among all rods over active length. For long-cooled fuel (4-year), the heat rate is assumed to be $1.4 \mathrm{~kW}$ per assembly.

\section{ACCIDENT CONDITIONS}

Prior to the occurrence of a postulated accident, the fuel assemblies and the cask are in thermal equilibrium with a $38^{\circ} \mathrm{C}\left(100^{\circ} \mathrm{F}\right)$ environment. Heat transfer to the environment, in this case, includes both radiation and forced convection from the installed cooling fans.

Accidents were postulated to consist of combinations of loss of mechanical cooling, loss of neutron shield water, loss of cavity coolant, and fires of several assumed durations and intensities. Calculations were made for the following specific series of accident assumptions, with Cases 1 through 9 for 180-day cooled fuel and Case 10 for 4-year cooled fuel: 
1. Initial loss of mechanical cooling only (LOMC)

2. Initial loss of mechanical cooling and neutron shield water (LOSW)

3. One-half-hour fire at $1010^{\circ} \mathrm{C}\left(1850^{\circ} \mathrm{F}\right)$

4. Two-hour fire at $1010^{\circ} \mathrm{C}\left(1850^{\circ} \mathrm{F}\right)$

5. Initial loss of mechanical cooling, neutron shield water, and cavity coolant water (LOCW)

6. One-half-hour fire at $1010^{\circ} \mathrm{C}\left(1850^{\circ} \mathrm{F}\right)$ with an initial LOCW

7. One-hatf-hour fire at $1300^{\circ} \mathrm{C}\left(2400^{\circ} \mathrm{F}\right)$ with an initial LOCW

8. Two-hour fire at $1010^{\circ} \mathrm{C}\left(1850^{\circ} \mathrm{F}\right)$ with an initial LOCW

9. Forty-minute fire at $1010^{\circ} \mathrm{C}\left(1850^{\circ} \mathrm{F}\right)$ with an initial LOCW

10. Two and one-half-hour fire with no cavity coolant and 4-year-old fuel.

At the initiation of any of the postulated fire cases, an immediate loss of mechanical cooling and neutron shield water is automatically assumed. In cases where an initial loss of cavity coolant water has not occurred, the cask is assumed to lie in such a position that action of the pressure relief valve which opens at $2.4 \mathrm{MPa}$ (gage) (350 psi) will expel only liquid. After the expulsion of all the cavity coolant water, the remaining air and water-vapor atmosphere is assumed to exist at a constant pressure of $2.4 \mathrm{MPa}$ (gage) (350 psia).

\section{ANALYTICAL APPROACH}

The analysis was performed with a heat transfer cole developed at BNW called TRUTH, which considers a physical system as a collection of discrete volumes interconnected by appropriate heat flow paths. The volume dimensions, properties, and interconnections are specified by the user to represent the physical configuration. The volumes: 1) may be either isothermal, passive heat capacities, heat generating; 2) may simulate a flowing incompressible fluid or; 3) may be a stationary pool, as used in this analysis, with liquid below and an air/steam mixture above an interface with a variable level.

The heat flow paths which connect any two volumes have no heat capacity or heat generating capability but only an area and a heat conductance. Heat 
flow occurs if the temperatures of the two connected volumes differ. The internal computation logic is provided to allow the connection to simulate conduction, forced and free convection, radiation, mass flow, boiling, condensation, evaporation from a liquid vapor interface, or a specified time-varying heat flux.

Since the number and the order of connections are arbitrary the code is not limited to any specific geometry. General three-dimensional systems may be simulated with relative ease. Both steady-state and transient problems can be considered. Transients are computed implicitly and have no time step limitation. They may begin from either a given initial condition or a previous steady-state solution.

One-half of the cask was modeled three-dimensionally by dividing it into 30 volumes as shown in Figure D.1, with the associated node connection schematic in Figure D.2. In the cask interior, the fuel was considered to consist

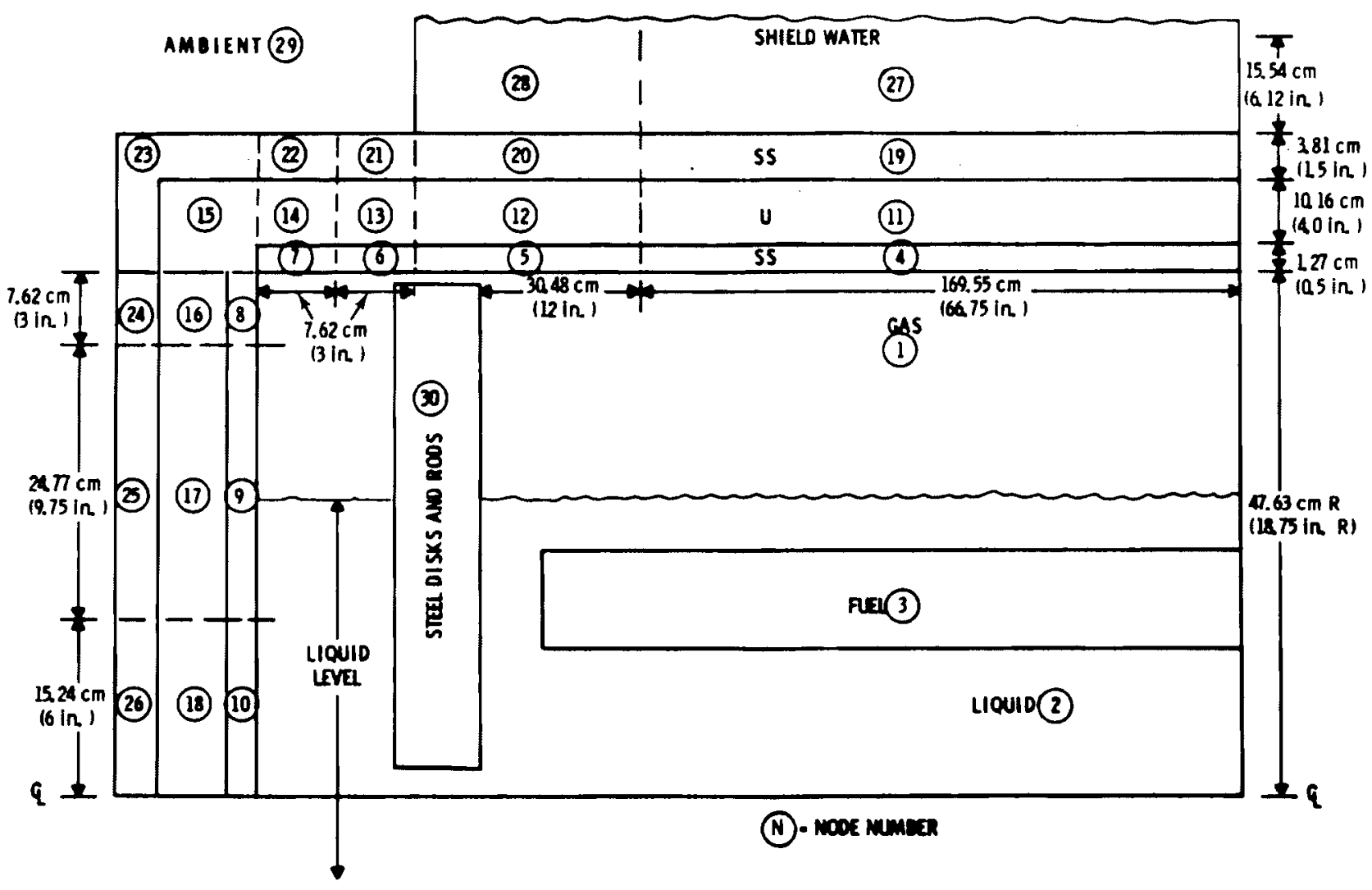

FIGURE D.1. Cask Noding Scheme 


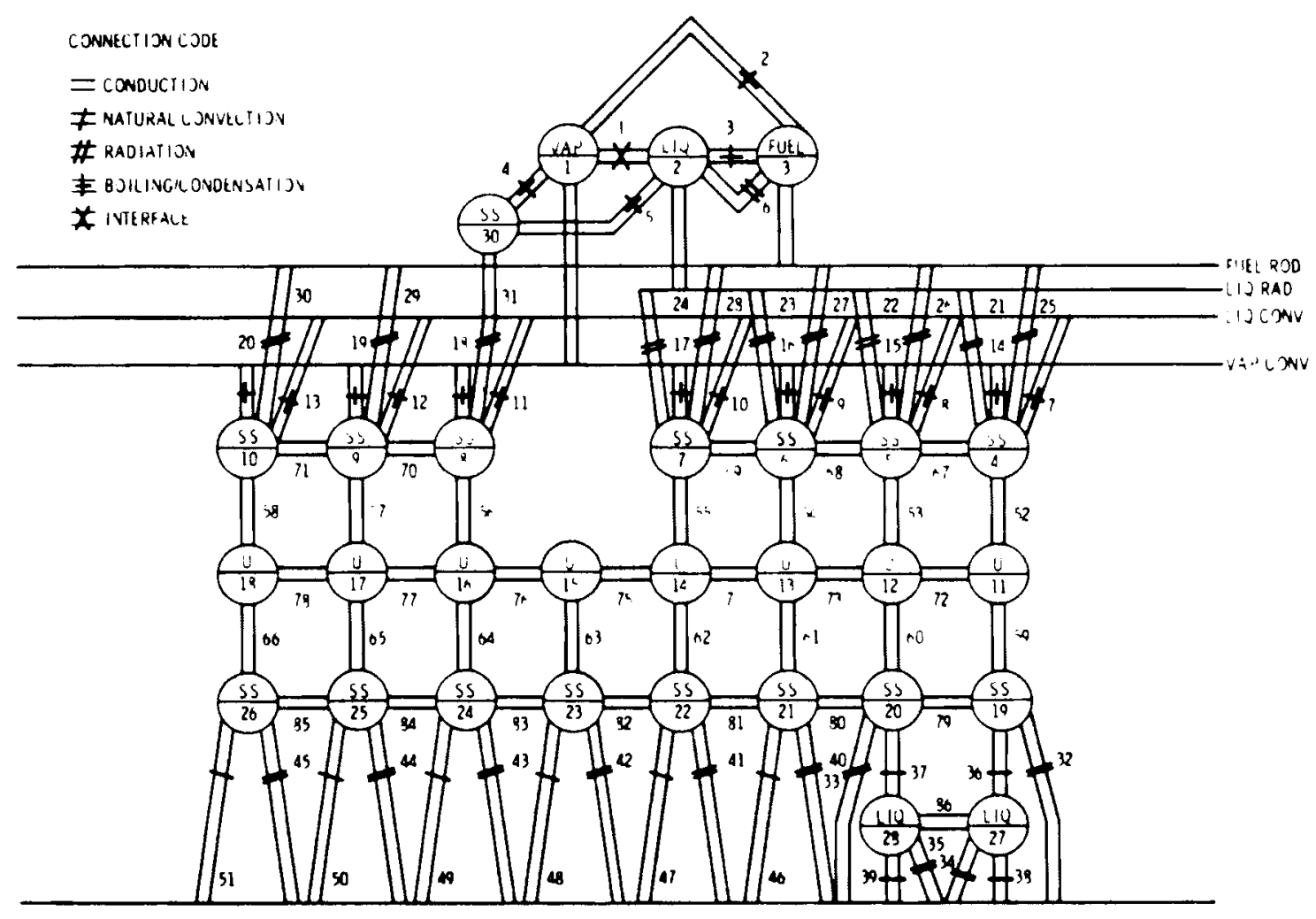

FIGURE D.2. Cask Node Connection Schematic

of the fuel rods plus their stainless steel baskets and surrounding boron carbide rods. The relatively massive spacer discs and bars were lumped together into a structure volume.

The cavity coolant in considered to exist as a pool of water with a variable level and a mixture of air and vapor above. When the cask is filled, approximately $0.57 \mathrm{~m}^{3}\left(20 \mathrm{ft}^{3}\right)$ of water is drained off to allow for expansion as the cask comes to steady-state. This volume of air is input as an initial condition.

Radiation between the fuel and cavity walls, fuel, and the liquid surface, and cavity walls and liquid surface is considered by assuming the fuel to be a cylinder having the same average radius as the actual fuel bundles. Radiation is assumed to occur only through the gaseous phase and the surface areas available for radiation heat transfer are continually adjusted as the liquid level changes. 
Coolant convection within the cask is simulated by assuming a very high thermal conductivity for both the liquid and the gas. Heat transfer coefficients are then applied to the solid boundary to represent boiling, condensation, evaporation or simply natural convection within the fluid. The presence of noncondensible gas is accounted for in both the gaseous phase coefficient, depending on the air mass fraction.

The fuel temperature predicted by TRUTH under these conditions is actually the temperature of a nominal fuel rod close to the outside surface of the fuel bundle. When the cask is water filled, this is a good approximation for all fuel rods. Under dry cask conditions, however, the outer rods may be much cooler than the fuel rods in the interior. Under dry cask conditions, the temperature of the interior fuel rods is estimated by an experimental correlation which relates the maximum fuel temperature of the interior cask wall temperature considering the effects of radiation and natural convection. (1) This correlation is applicable only in the steady-state; therefore, no estimate of maximum fuel temperature is made during transients when the cask wall temperature is changing rapidly.

Outside the cask, heat transfer through the neutron shield water and the corrugated shield wall includes natural convection within the shield water and natural convection with air and radiation on the exterior. Convection of the neutron shield water is simulated by computing an effective thermal conductivity for the water. When the shield water is lost, radiation and natural convection in vapor transfer heat between the cask body and the inner surface of the corrugated shield wall.

Natural convection heat transfer correlations, equivalent water thermal conductivities and material properties were taken from Reference 1. All properties are considered constant with temperature except for the emittance of radiation stainless steel surfaces which is increased as a function of temperature to account for oxidation.

\section{RESULTS}

The TRUTH model was qualified by comparing its predictions to some performed by General Electric ${ }^{(1)}$ on a similar cask design. However, the General 
Electric model did not consider the presence of noncondensibles as does TRUTH. Results for both normal steady-state and a loss-of-mechanical cooling accident compared favorably.

The steady-state temperatures of the cask components before the accident are shown in Figure D.3. The steady-state cavity pressure is about $496 \mathrm{kPa}$ (72 psi), with a liquid level of $72 \mathrm{~cm}$ (28.5 in.), which is $2.3 \mathrm{~cm}$ (9 in.) from the top of the cavity. The maximum steady-state fuel temperature is about $135^{\circ} \mathrm{C}\left(276^{\circ} \mathrm{F}\right)$.

The transient behavior of the cask and fuel assemblies during each of the nine postulated accident conditions are summarized in the following paragraphs. Case 1 - Initial Loss of Mechanical Cooling

The transient cask and fuel temperatures for this case are shown in Figure D.4. The reduction in surface cooling, due to the loss of mechanical

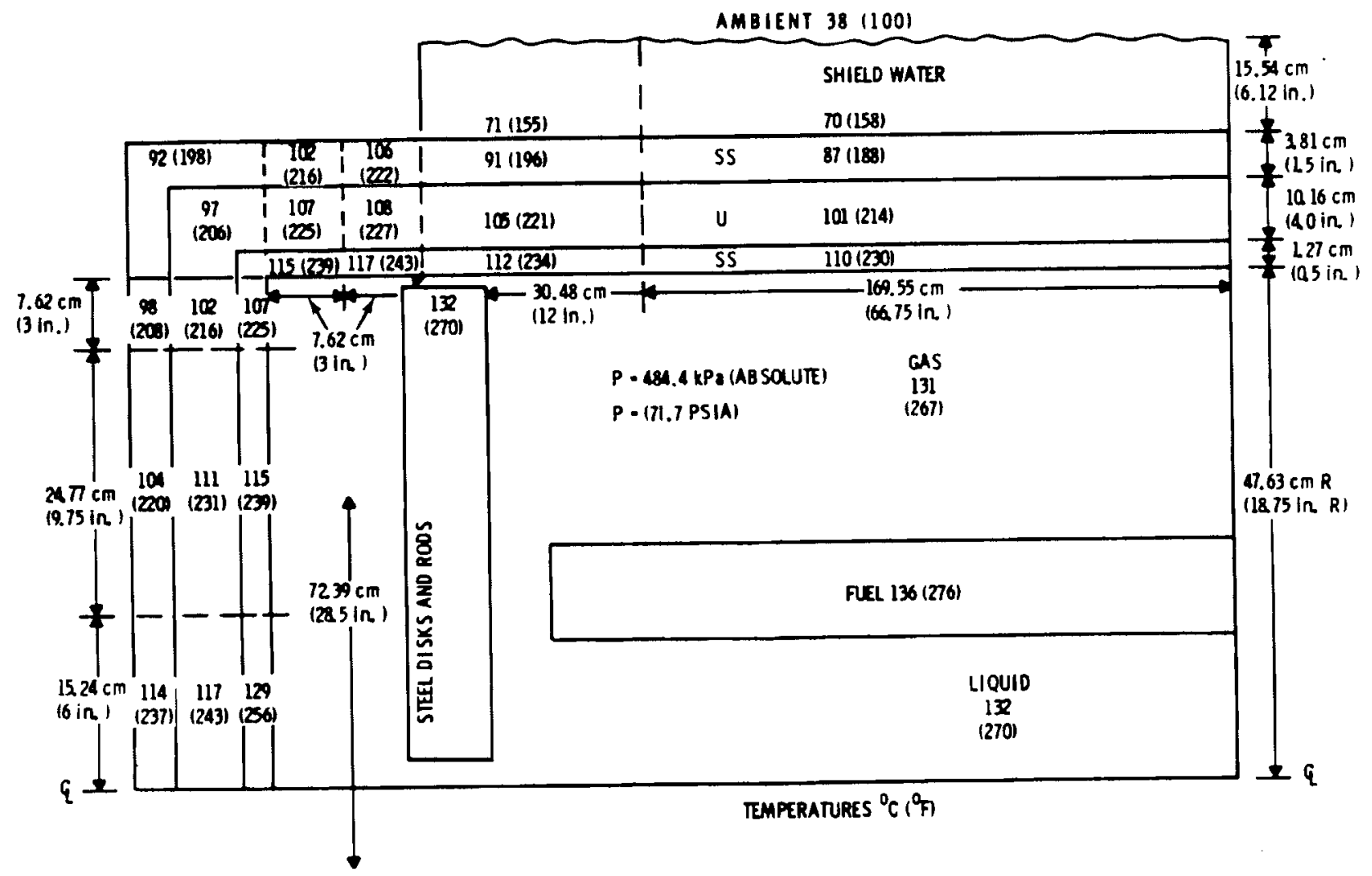

FIGURE D.3. Normal Cooling Steady-State Cask Temperature Distribution 


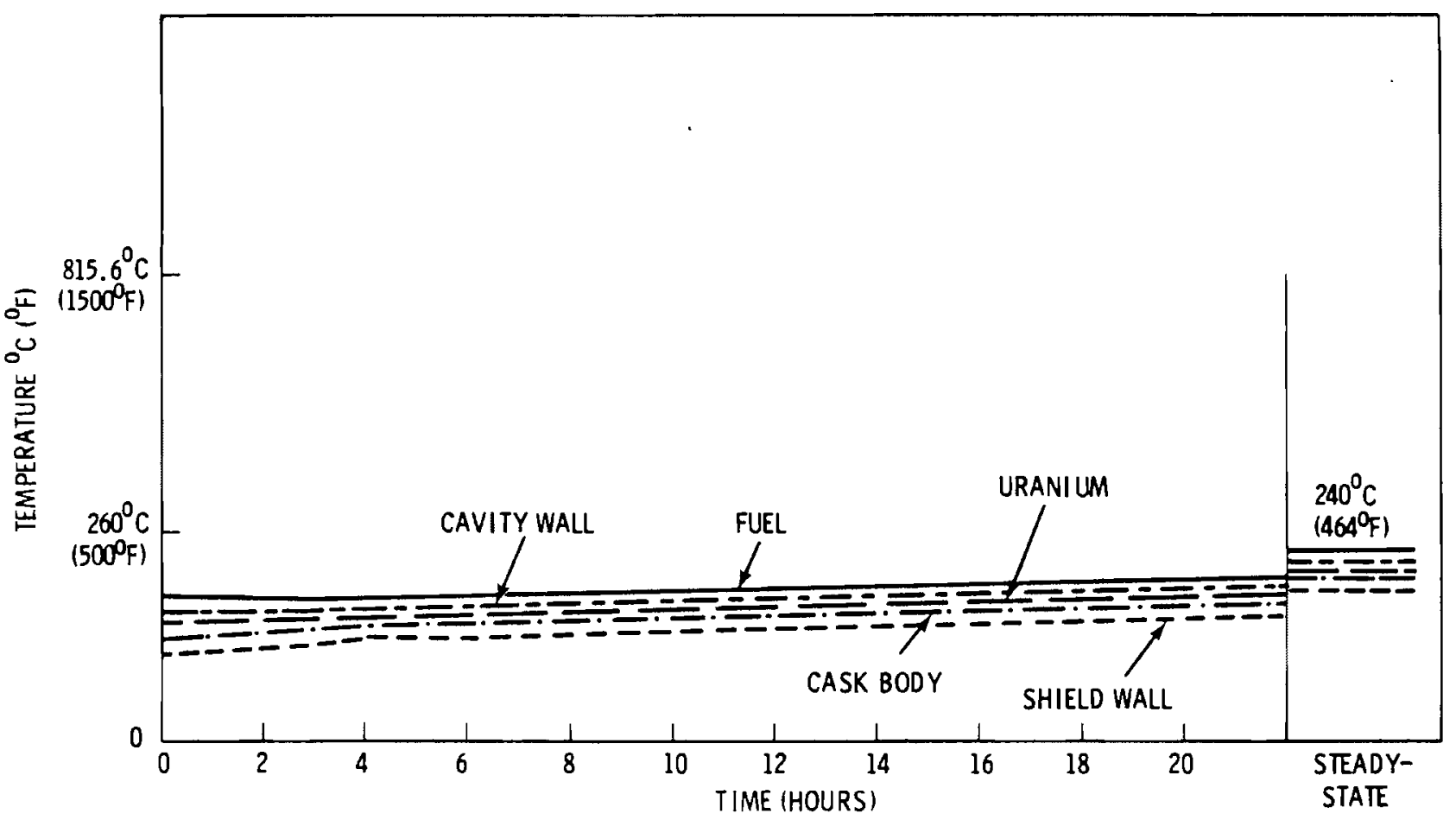

FIGURE D.4. Case 1 - Initial LOMC (No Fire or LOSW)

cooling, is insufficient to cause venting of the cavity fluid. The transient is characterized by a very slow, nearly linear temperature increase approaching a steady-state approximately 60 hours after initiation of the accident. The maximum fuel temperature at the steady-state is about $185^{\circ} \mathrm{C}\left(366^{\circ} \mathrm{F}\right)$. The cavity coolant pressure rises to $1.4 \mathrm{MPa}$ (gage) (204 psi) and the increased temperature causes the liquid to expand and raise the level to about $77.8 \mathrm{~cm}(30.6 \mathrm{in}$.). Case 2 - Initial Loss of Mechanical Cooling and Shield Water

The absence of water from the neutron shield water annulus significantly increases the resistance of the cask to radial heat flow. This causes the temperatures to rise at a much faster rate than the loss of mechanical cooling alone, as is shown in Figure D.5. The cavity temperature rises to the point that the cask water begins to drain at about 33 hours after initiation of the accident and the cask cavity is empty about one hour and forty minutes later. After all the coolant has been expelled, the fuel temperatures rise sharply and approach a steady-state approximately 15 to 20 hours later. The hottest 


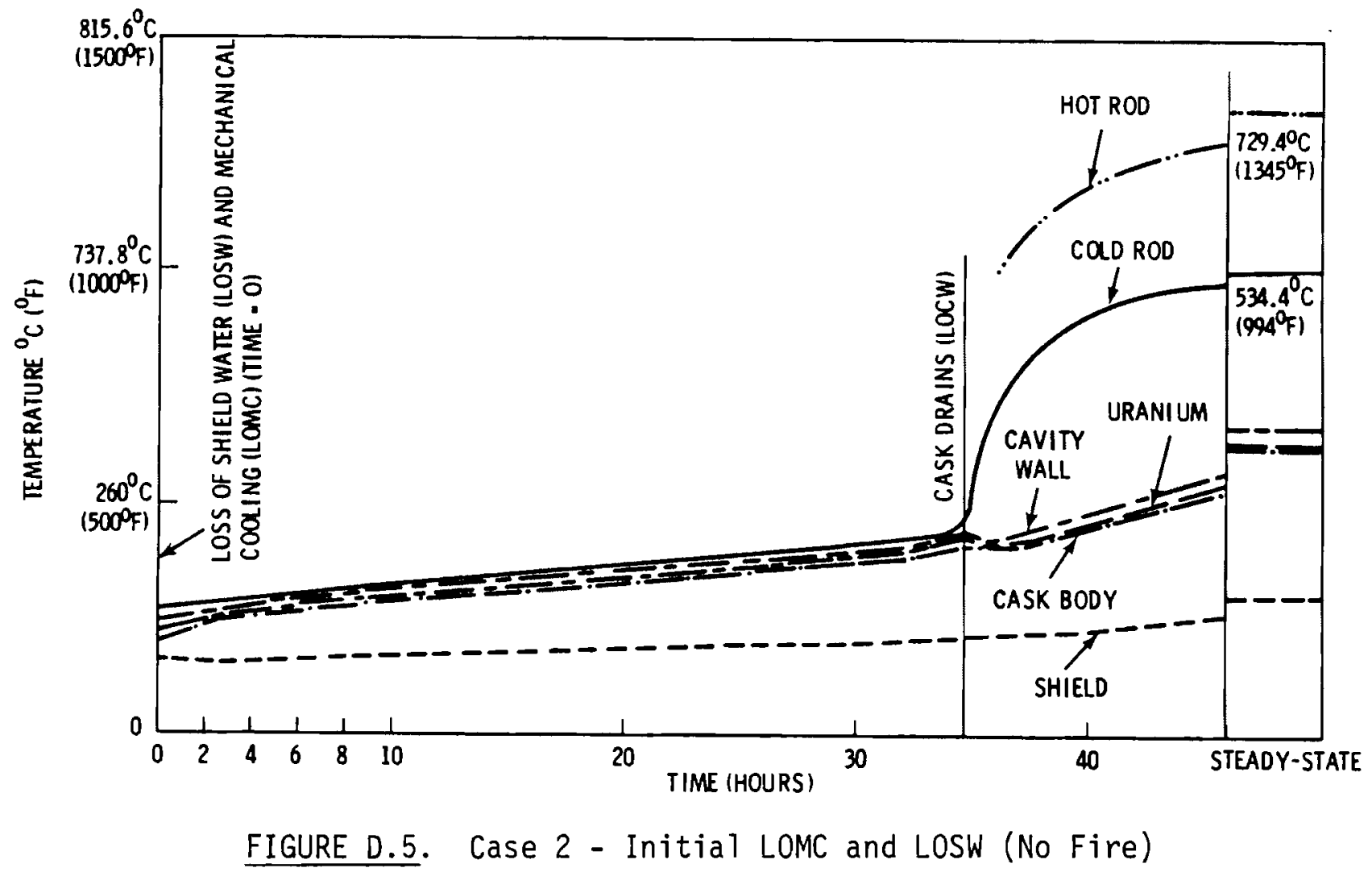

fuel rod at the center of the dry cask has a steady-state temperature of about $730^{\circ} \mathrm{C}\left(1345^{\circ} \mathrm{F}\right)$, while the cooler rods on the outer boundaries of the bundles have a steady-state temperature of about $535^{\circ} \mathrm{C}\left(994^{\circ} \mathrm{F}\right)$.

This case yields the highest steady-state maximum fuel rod temperatures of any of the nine considered, including fires. The reason is that the fire cases raise the outer cask surface temperatures to such high values that the surface emittance increases, which increases the rate of steady-state radiation heat loss to the environment after the fire is out. In this case, where no fire has occurred, the surface emittances remain at their relatively low initial values, providing the minimum steady-state heat transfer rate. A higher transient temperature is reached in the two-hour fire and initial loss of cavity water (Case 8 ), where the hottest rod temperature peaks at about $790^{\circ} \mathrm{C}\left(1450^{\circ} \mathrm{F}\right)$ but then decreases to a much lower steady-state value. Case 3 - Half Hour Fire at $1010^{\circ} \mathrm{C}\left(1850^{\circ} \mathrm{F}\right)$

The large heat capacity of the huge mass of stainless steel and uranium shielding surrounding the fuel cavity prevents this short duration fire from 
having any immediate effect on the fuel temperature. The inner cavity wall temperature shows no peak near the time of the fire, but rises monotonically from the initiation of the accident. The increased heat input to the cask system does cause the cavity water to be expelled much sooner however. This occurs over a period of about 40 minutes beginning about 10 hours and 12 minutes after the start of the fire. There is also a small discharge of cavity water which drops the liquid level from 79.5 to $62.0 \mathrm{~cm}(31.3$ to $24.4 \mathrm{in}$.) over approximately 1 hour beginning about 4 hours and 40 minutes after the start of the fire. After all the cavity liquid is expelled, the cask and fuel temperatures behave exactly as they did in Case 2, except that the peak temperatures are slightly lower, as shown in Figure D.6.

Case 4 - Two-Hour Fire at $1010^{\circ} \mathrm{C}\left(1850^{\circ} \mathrm{F}\right)$

The two-hour fire is of sufficient duration to cause a very severe perturbation of the cask and fuel temperatures as illustrated in Figure D.7. The main effect is that the cavity water is expelled over a period of only a half hour, which begins about 20 minutes before the fire is out. This loss of

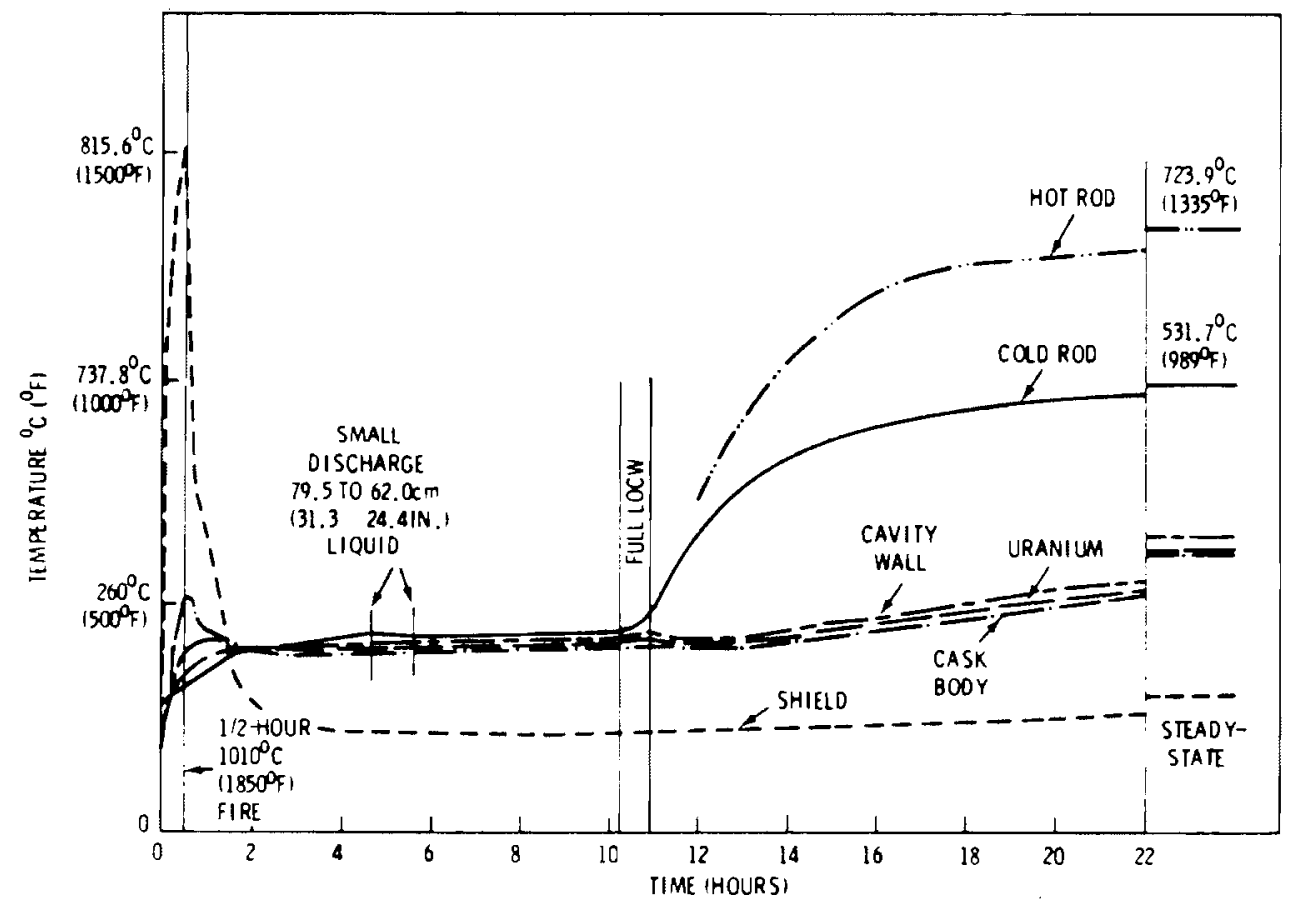

FIGURE D.6. Case 3 - Half-Hour Fire at $1010^{\circ} \mathrm{C}\left(1850^{\circ} \mathrm{F}\right)$ (with LOSW and LOMC) 


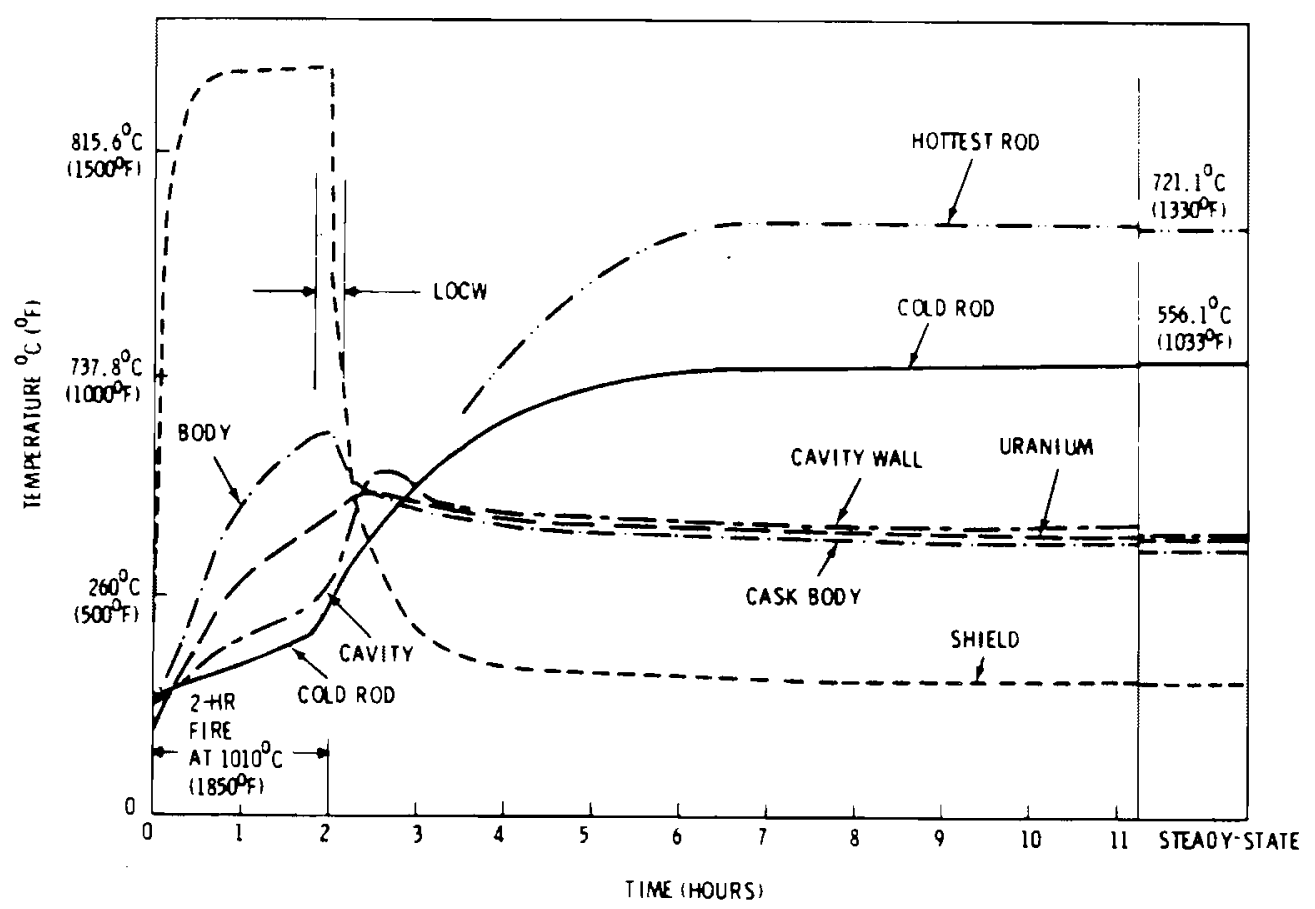

FIGURE D.7. Case 4 - Two-Hour Fire at $1010^{\circ} \mathrm{C}\left(1850^{\circ} \mathrm{F}\right.$ ) (With LOSW and LOMC)

cavity heat capacity causes all cask wall segment temperatures to peak 38 to $93^{\circ} \mathrm{C}$ $\left(100\right.$ to $200^{\circ} \mathrm{F}$ ) above their steady-state values but the concurrent degradation in heat transfer between the fuel assemblies and the cavity wall again protects the fuel from immediate influence by the fire.

Case 5 - Initial Loss of Cavity Water - (No Fire)

In this case the initial loss of coolant's heat capacity and relatively high heat transfer allow the fuel rod temperatures to begin increasing immediately. The shape of the transient illustrated in Figure D.8 is much the same as in previous cases where the cavity coolant was lost. The maximum steady-state fuel rod temperature of $725^{\circ} \mathrm{C}\left(1340^{\circ} \mathrm{F}\right)$ is attained approximately 40 hours after the initiation of the transient. The full cask temperature distribution at steady-state is shown in Figure D.9.

Case 6 - Initial Loss of Cavity Water with Half-Hour Fire at $1010^{\circ} \mathrm{C}\left(1850^{\circ} \mathrm{F}\right)$

In Case 3, the half-hour fire with the cavity coolant present, relatively minor perturbation in fuel rod and interior cask temperatures was revealed. 


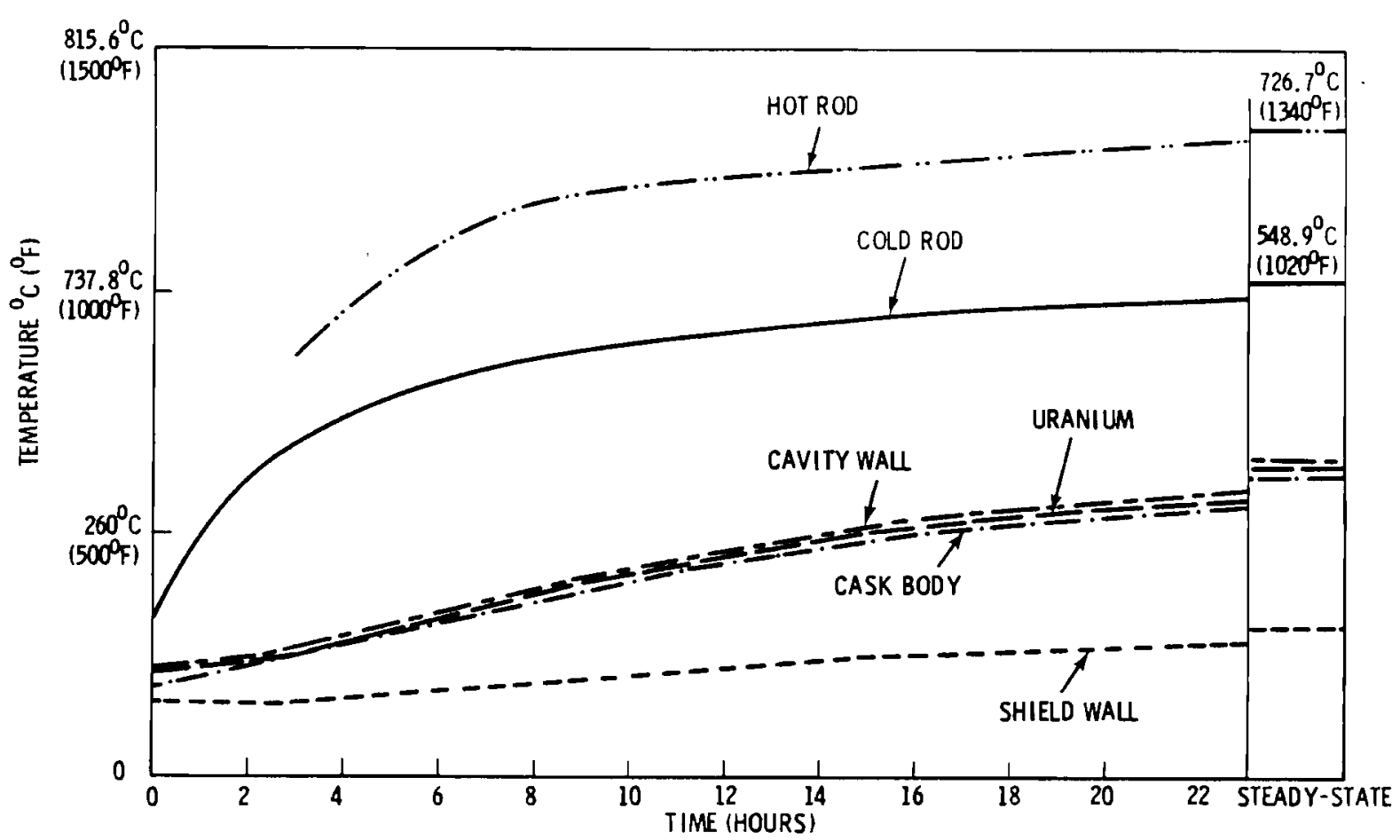

FIGURE D.8. Case 5 - Initial LOCW, LOMS, and LOSW (No Fire)

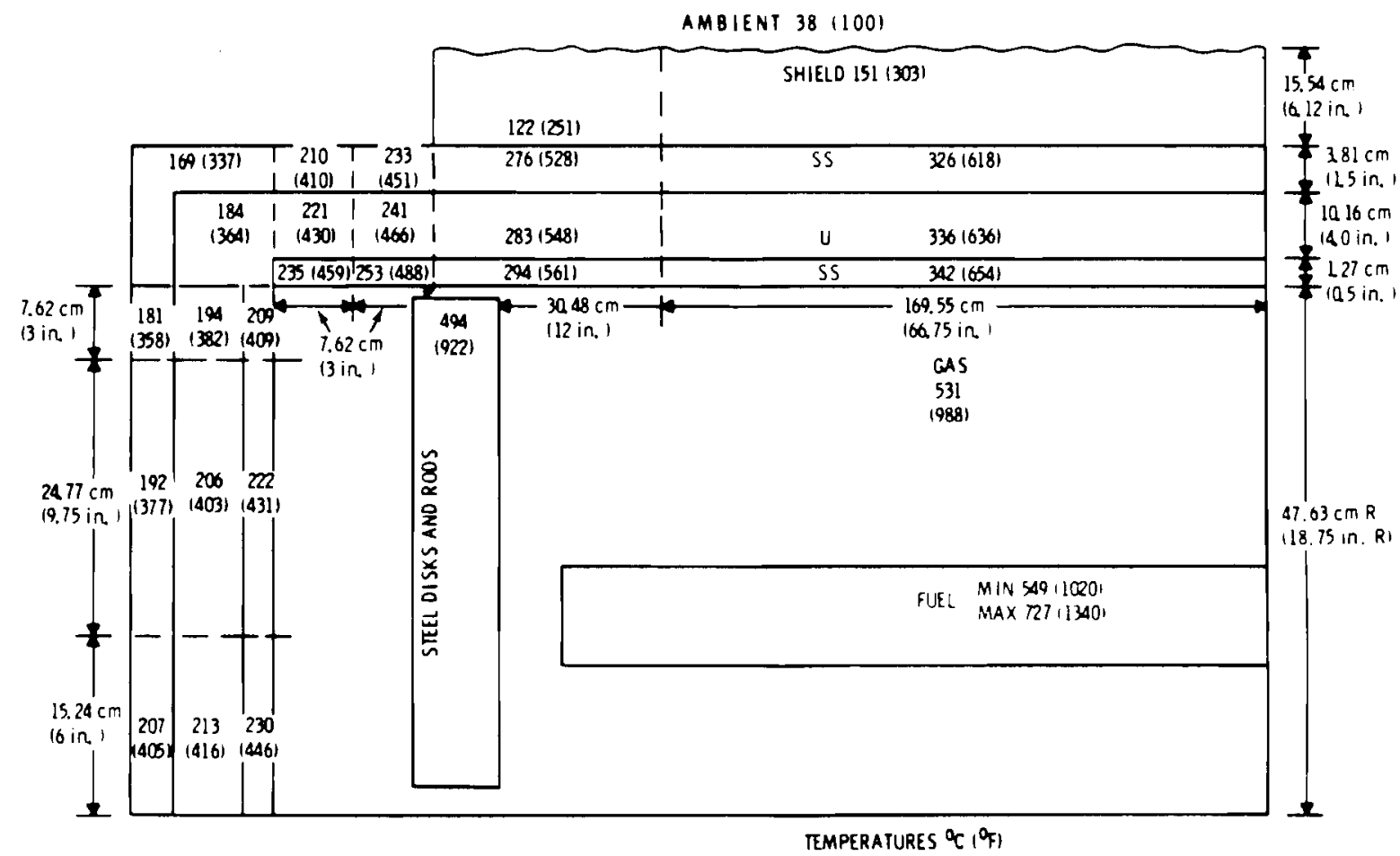

FIGURE D.9. Dry Cask Steady-State Temperature Distribution 
The results of this case in Figure $D .10$ show that the heat capacity of the cask walls is still sufficient to protect the fuel from the direct effects of a half-hour fire even with initial loss of cavity coolant. The only visible effect of the fire is that the steady-state is attained somewhat sooner and the maximum fuel rod temperature is slightly lower, du to the increase in surface emissivity.

Case 7 - Initial Loss of Cavity Water with a Half-Hour Fire at $1300^{\circ} \mathrm{C}\left(2400^{\circ} \mathrm{F}\right)$

The results of this case shown in Figure $D .11$ are qualitatively similar to the previous half-hour fire at the lower temperature. At $1300^{\circ} \mathrm{C}\left(2400^{\circ} \mathrm{F}\right)$, however, the effect on the cask walls is much more pronounced. The wall temperatures are raised about $66^{\circ} \mathrm{C}\left(150^{\circ} \mathrm{F}\right)$ above their steady-state value shortly after the fire ceases, and the hottest fuel rod temperature may peak slightly higher than its steady-state value of $725^{\circ} \mathrm{C}\left(1335^{\circ} \mathrm{F}\right)$, due to the generally hotter cavity wall temperatures. Cask wall heat capacities still prevent any immediate effect of the fire on the fuel temperatures.

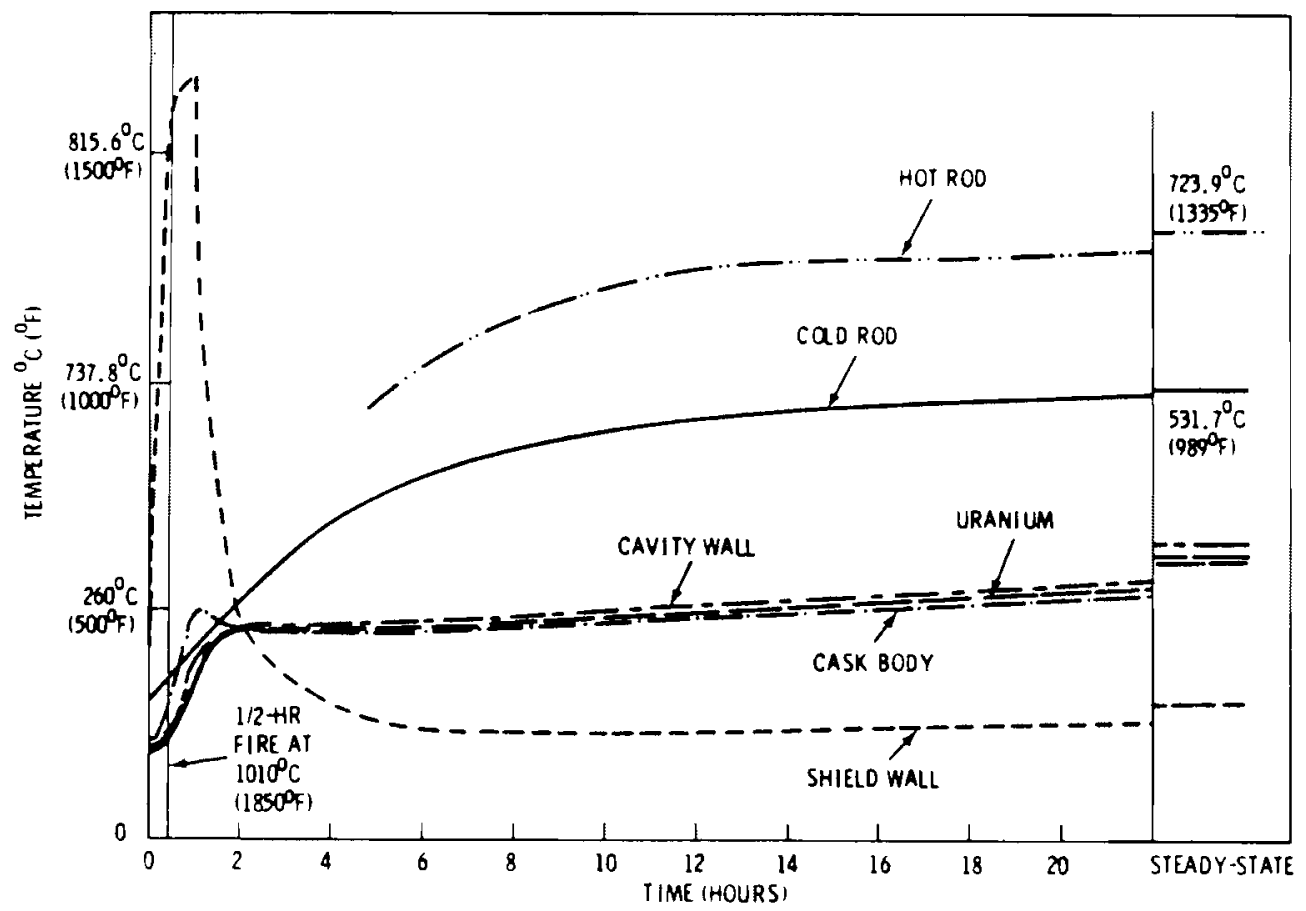

FIGURE D.10. Case 6 - Initial LOCW, LOMC, and LOSW Half-Hour Fire $1010^{\circ} \mathrm{C}\left(1850^{\circ} \mathrm{F}\right)$ 


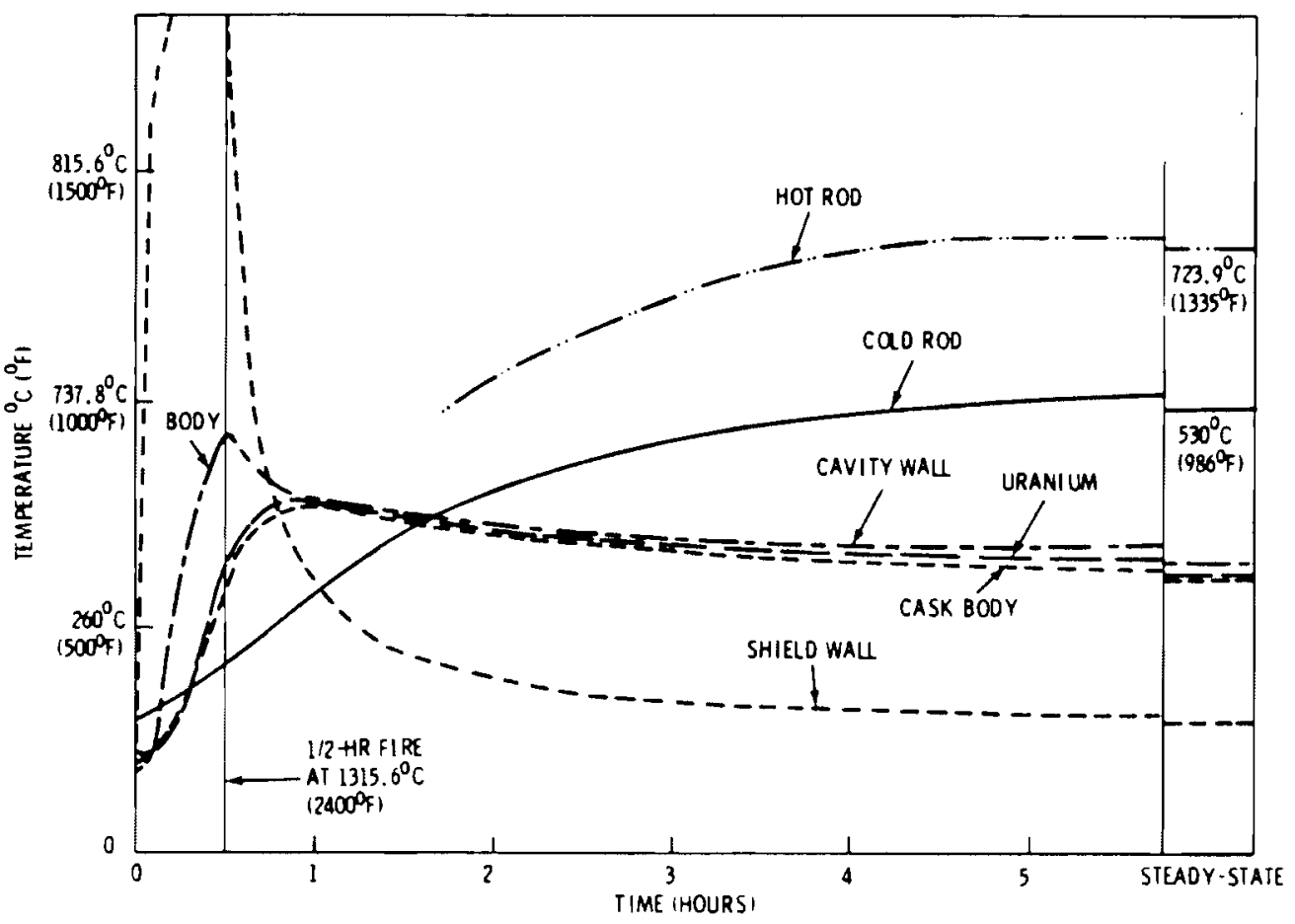

FIGURE D.11. Case 7 - Initial LOCW, LOMC, and LOSW Half-Hour Fire $1300^{\circ} \mathrm{C}\left(2400^{\circ} \mathrm{F}\right)$

Case 8 - Initial Loss of Cavity Water with a Two-Hour Fire at $1010^{\circ} \mathrm{C}\left(1850^{\circ} \mathrm{F}\right)$

The two-hour fire is of sufficient duration to overcome the cask wall heat capacity and to cause a significant rise in fuel temperatures as indicated in Figure D.12. The colder rods on the periphery of the fuel bundles peak at about $625^{\circ} \mathrm{C}\left(1160^{\circ} \mathrm{F}\right)$, which is $130^{\circ} \mathrm{C}\left(270^{\circ} \mathrm{F}\right)$ above their final steady-state value of $480^{\circ} \mathrm{C}\left(890^{\circ} \mathrm{F}\right)$. The peak temperature of the hot interior fuel rods during this initial transfer peak cannot be calculated exactly with this method of analysis. However, they are estimated to reach approximately $790^{\circ} \mathrm{C}\left(1450^{\circ} \mathrm{F}\right)$ before dropping back to a steady-state value of $695^{\circ} \mathrm{C}\left(1285^{\circ} \mathrm{F}\right)$.

The reason that the maximum fuel rod temperature is so much lower than seen in the previous cases is that the radiating stainless steel surfaces under the shield wall and in the cavity reached a sufficiently high temperature to increase their emittance significantly above its steady-state value. Note, also, that the shield wall temperature reached an equilibrium temperature with the fire at approximately one hour after the fire started. Peak fuel 


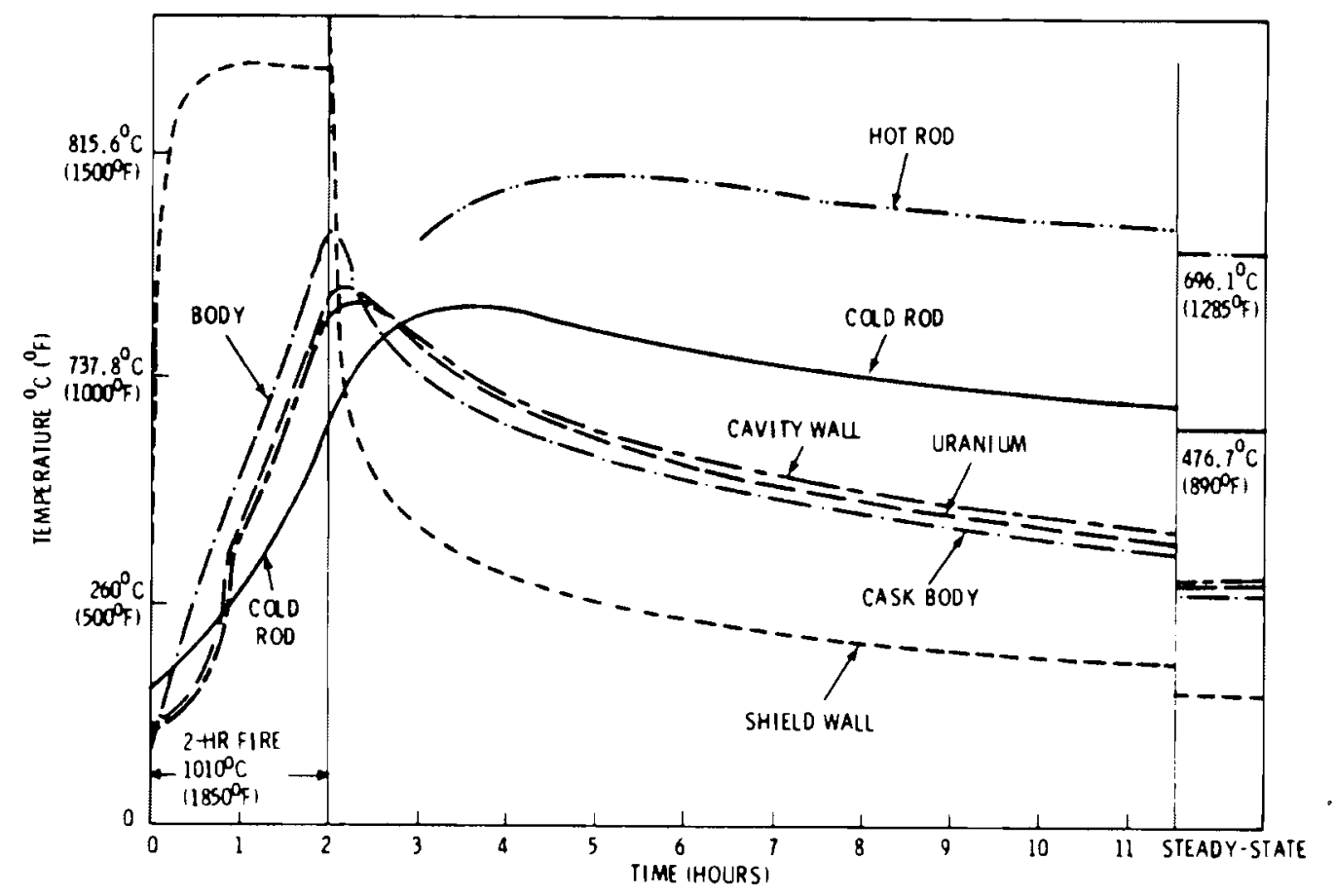

FIGURE D.12. Case 8 - Initial LOCW, LOMC, and LOSW Two-Hour Fire $1010^{\circ} \mathrm{C}\left(1850^{\circ} \mathrm{F}\right)$

temperatures occurred approximately two hours after the fire was out, or four hours after the initiation of the fire.

Case 9 - Initial Loss of Cavity Water with a Forty-Minute Fire at $1010^{\circ} \mathrm{C}\left(1850^{\circ} \mathrm{F}\right)$

This case was run to check the effect of a small increase in the duration of the half-hour fire at $1010^{\circ} \mathrm{C}\left(1850^{\circ} \mathrm{F}\right)$. It can be seen in Figure $\mathrm{D} .13$ that the results do not differ significantly from the half-hour fire in Case 6 . Case 10 - Dry Cask Two and One-Half Hour Fire at $1010^{\circ} \mathrm{C}\left(1850^{\circ} \mathrm{F}\right)$ with 4 -Year Cooled Fuel

This case was run to determine the length of fire required for 4-year cooled fuel to cause fuel element failure (i.e., fuel above $570^{\circ} \mathrm{C}\left(1050^{\circ} \mathrm{F}\right.$ ). Computer runs with a 2-hour fire showed no fuel failure (see Figure D.14). 


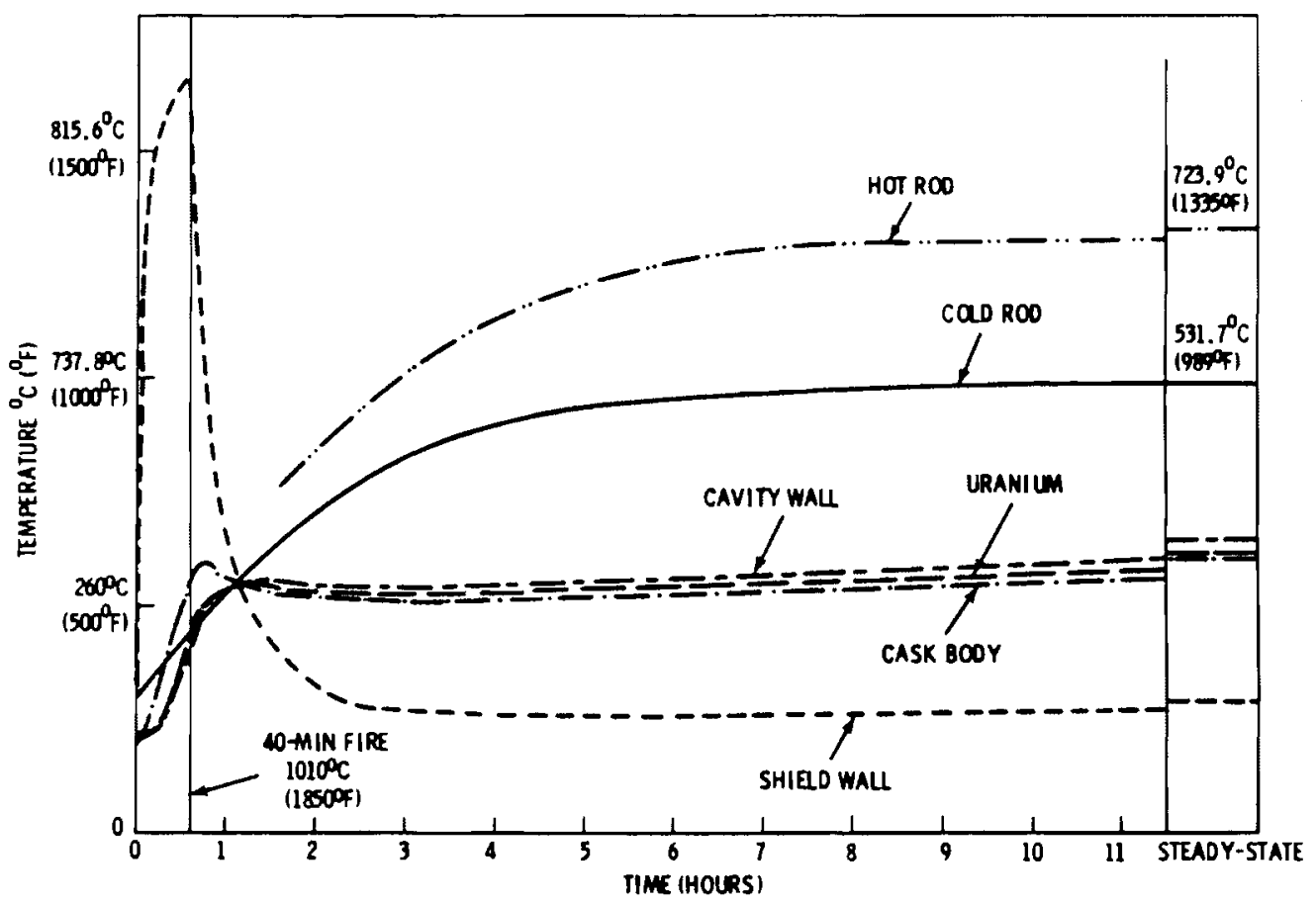

FIGURE D.13. Case 9 - Initial LOCW, LOSW, and LOMC Forty-Minute Fire $\left(1850^{\circ} \mathrm{F}\right)$

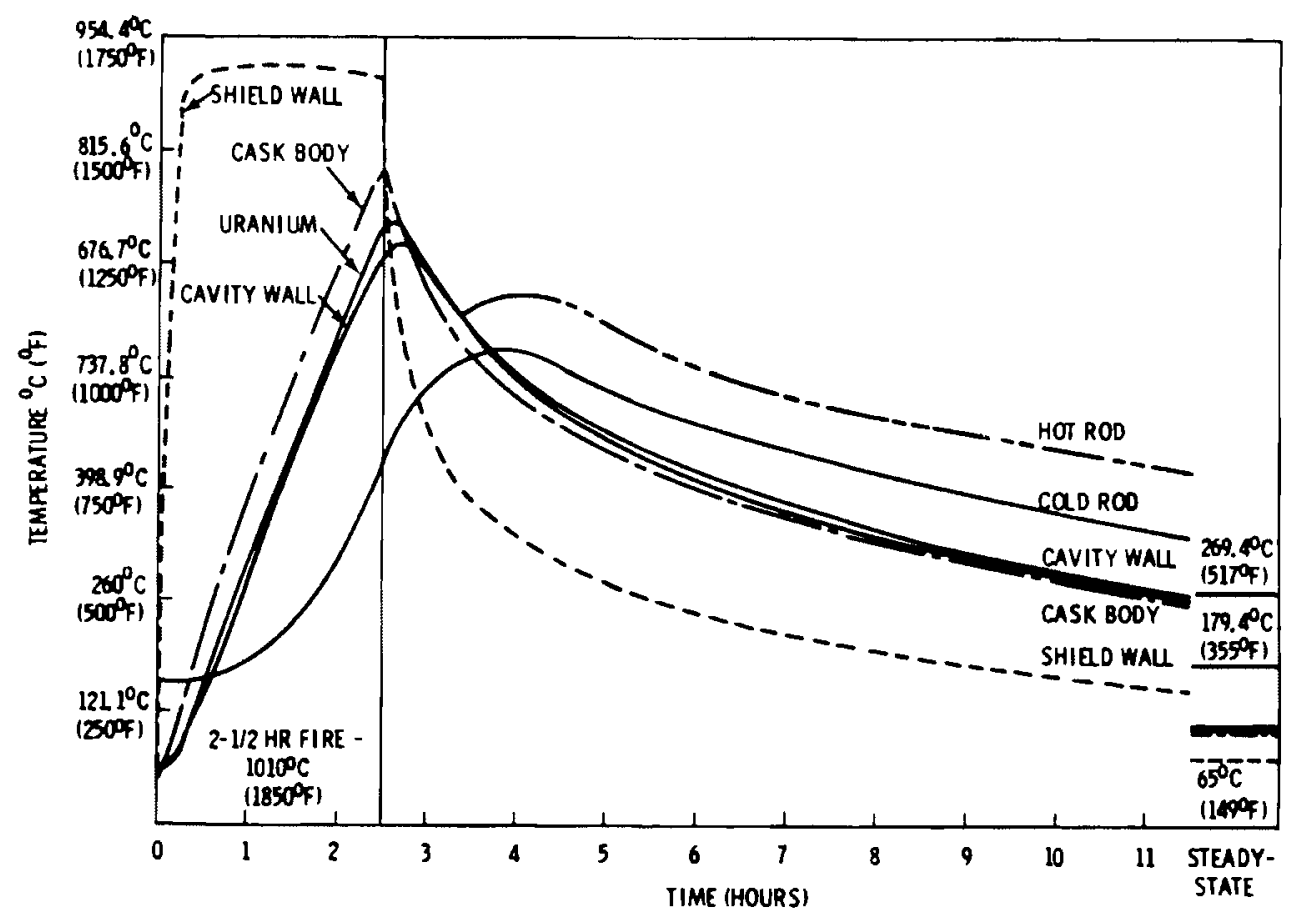

FIGURE 0.14. Case 10 - Dry Cask - Two-1/2-Hour Fire $1010^{\circ} \mathrm{C}\left(1850^{\circ} \mathrm{F}\right)$ 


\section{REFERENCE}

1. Design Analysis Report: IF-300 Shipping Cask. NED0-10084-1, General Electric Corporation, February 1973. 


\section{APPENDIX E}

FAULT TREE FOR SHIPMENT OF SPENT FUEL BY TRAIN 


\section{APPENDIX E}

\section{FAULT TREE FOR SHIPMENT OF SPENT FUEL BY TRAIN}

Figure E.1, Sheet 1, shows the top of the fault tree. The top event on the tree is the postulated release of radioactive material to man's environment during spent fuel shipment. Radioactive releases to the environment occur through release of material from one of the amin components of the cask. Detailed fault trees for the failure of various cask components are shown in Figure E.1, Sheets 2 through 13. Cask components through which releases of radioactive material could occur are: the cask head, closure seal, cask wall, pressure relief valves, drain valves and the vent valve.

Releases from the cask components occur from: 1) accident forces which cause failure of the component and release radioactive material from the fuel and 2) loss of coolant from the component failure caused by accidents or closure errors which result in release of radioactive material during transport. Both the cask component and the fuel may fail from the same accident event or they may fail from different events. Loss of cavity coolant may result from accident forces which fail one of the cask components or packaging errors which result in a loss of coolant. Loss of coolant itself or coolant radioactivity pluss fission products escaping from overheating fuel rods.

Each of the fault tree branches for the different cask components are then further broken down to basic events which can be assigned failure probabilities.

The list of identified events or failure elements used in the fault tree which could contribute to a release are shown in Table E.1. These elements are designated in the fault tree as " $X$ " with assoicated numerical designations and descriptive titles. Elements which have further development in the fault tree are designated by "A". The descriptive titles for the " $A$ " elements are given in Table E.2. The fault events in the tree designated by the circle symbol are not analyzed individually becaue they are not considered to be events with significant risks but are included in the fault tree for completeness in illustrating all the conditions considered in developing the tree. 


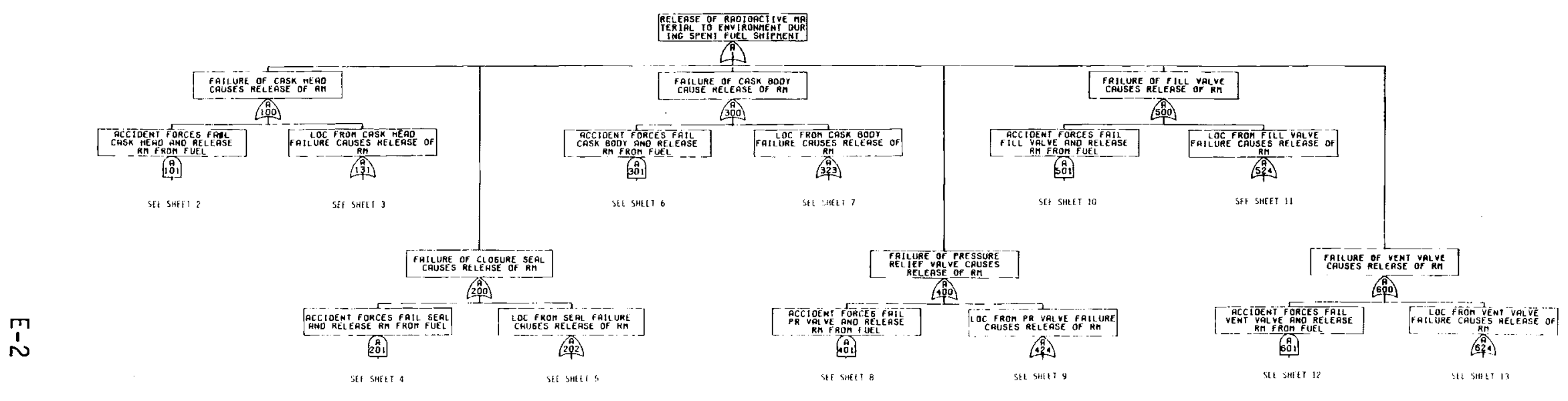

SHEE 1

FIGURE E.1. Spent Fuel Cask Rail Shipment Fault Tree 


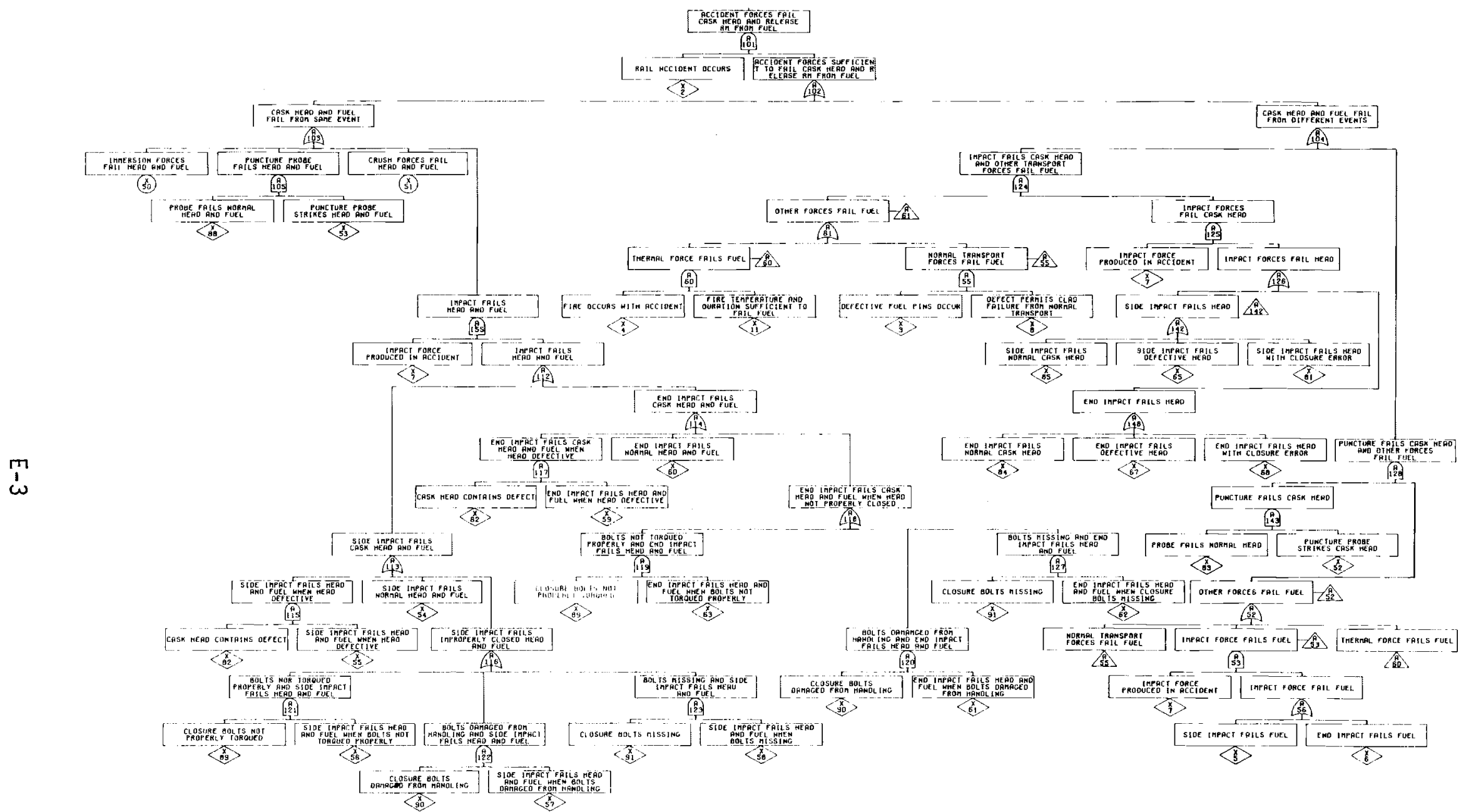




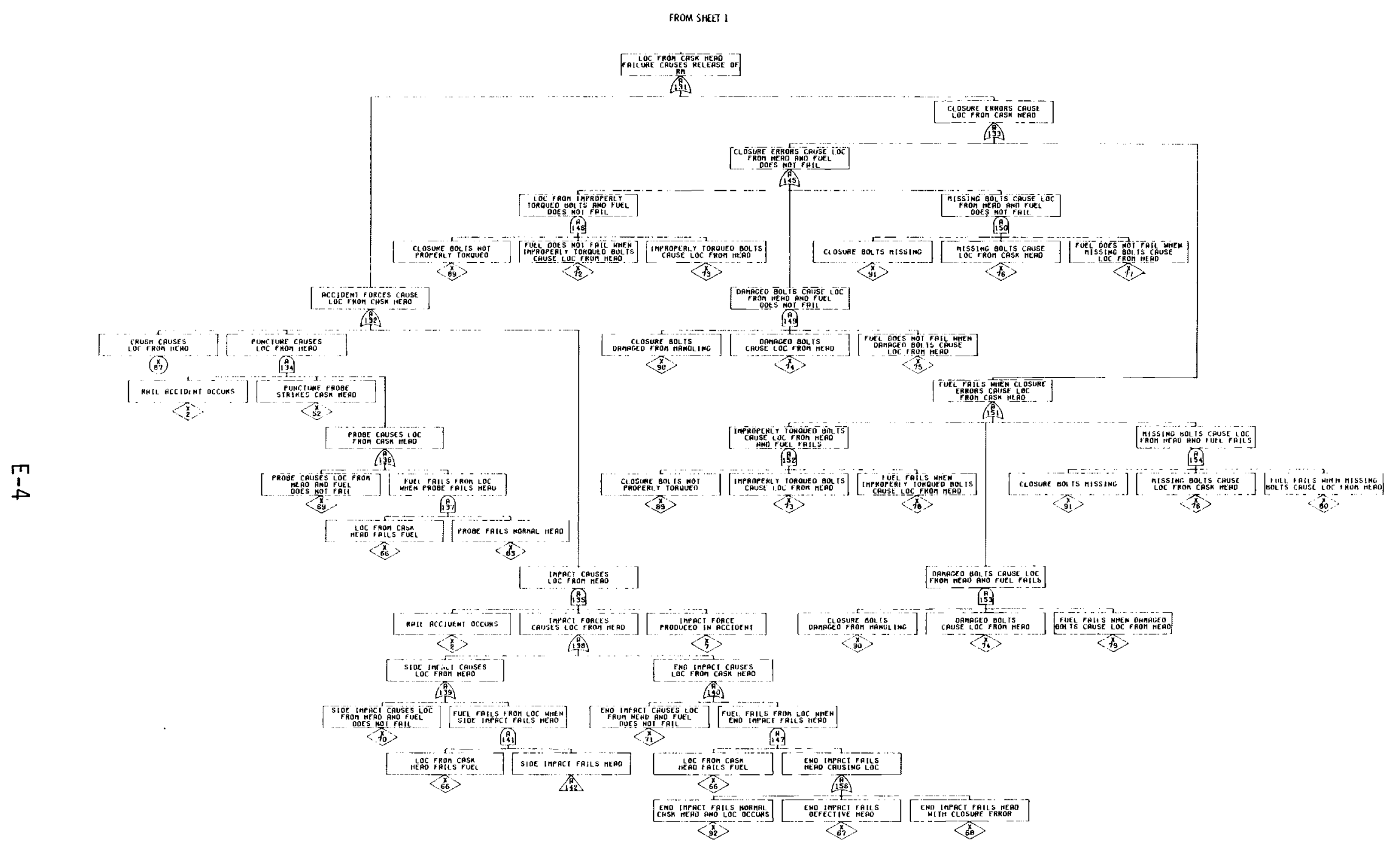

SHEEI 3

FIGURE E.1. (contd) 


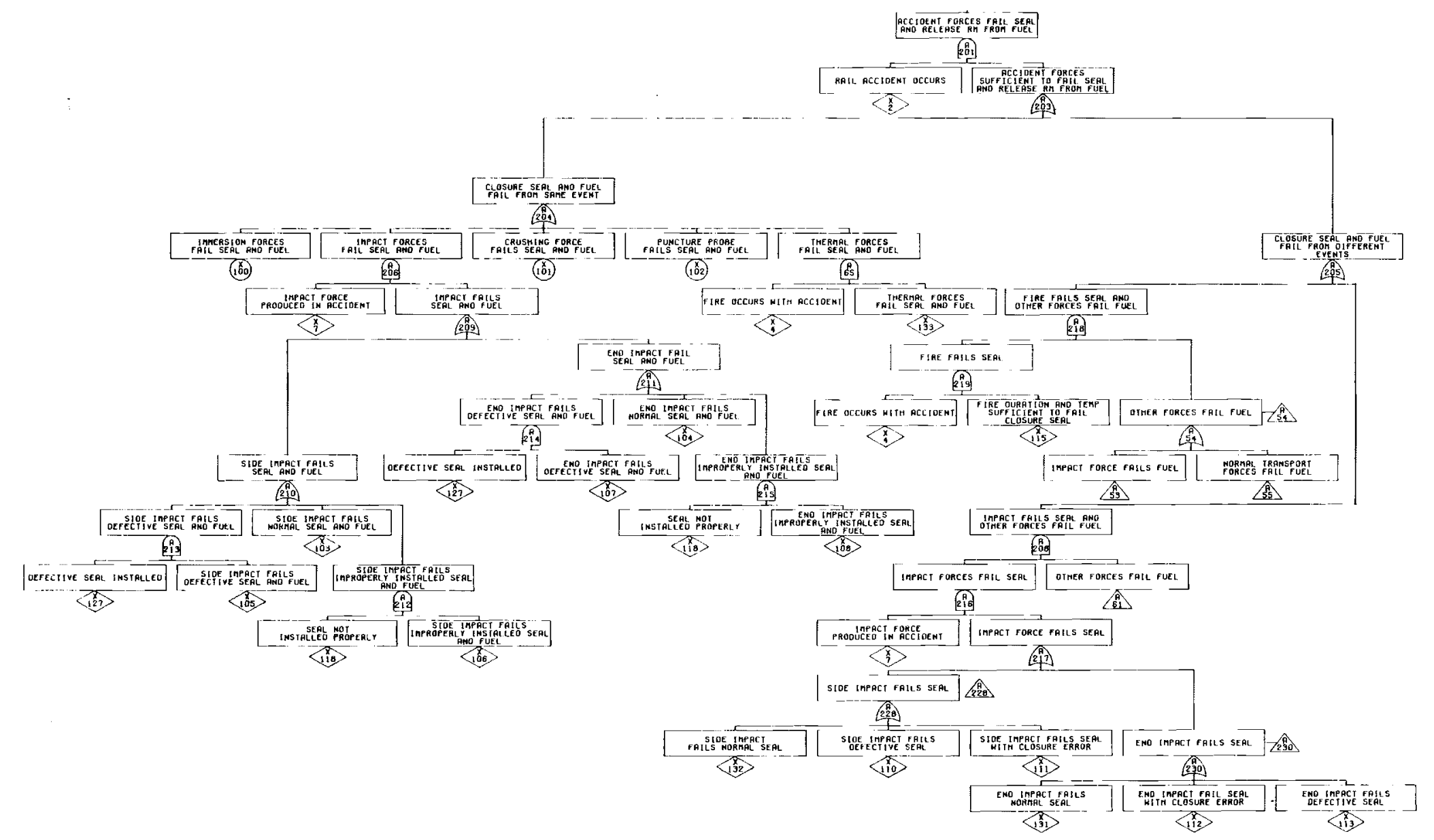


FROM SHEET 1

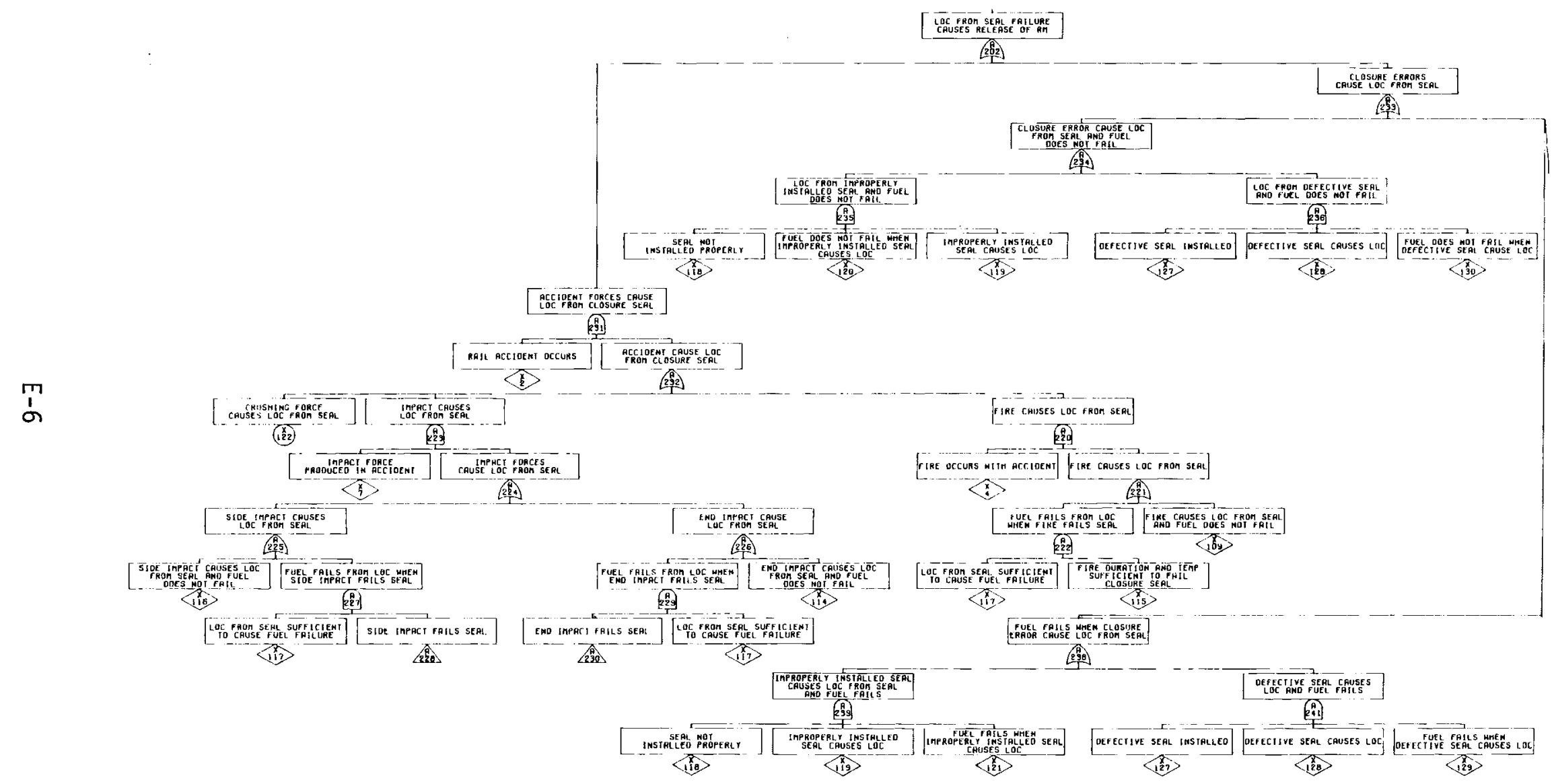

SHEE 5

FIGURE E.1. (contd) 
FROM SHER I

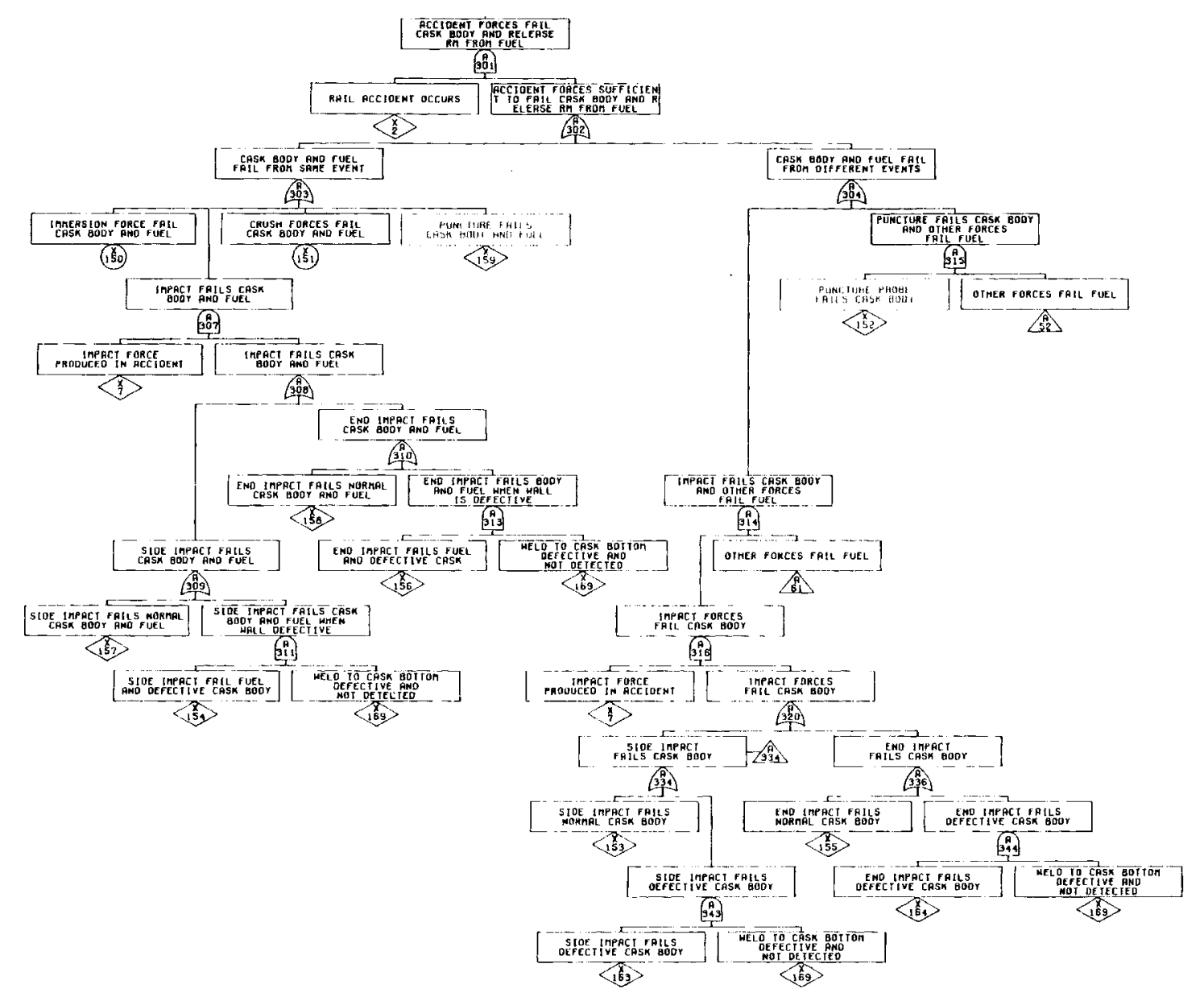

SHEA 6

FIGURE E.1. (contd) 
FROM SHEET I

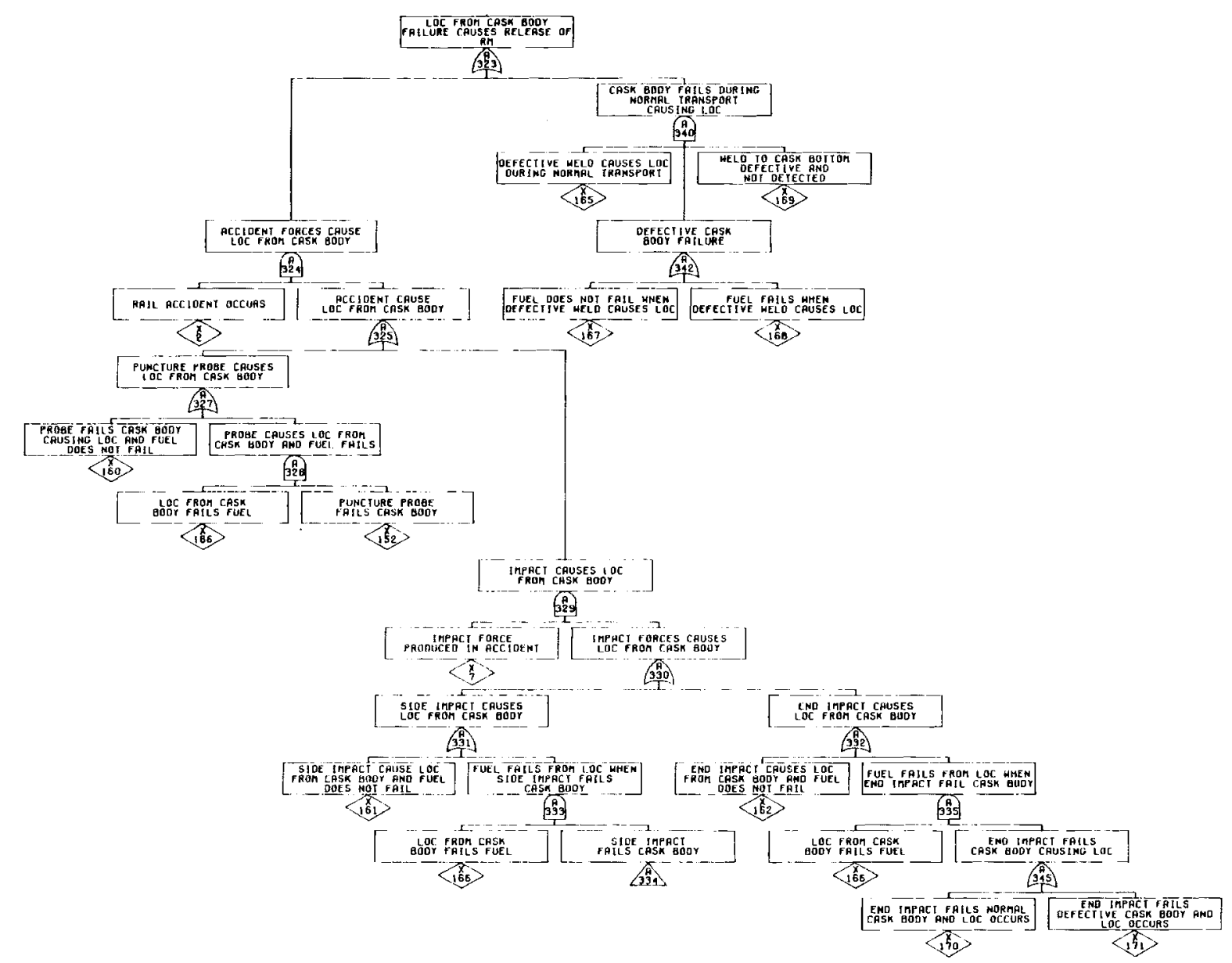

SHEET 7

FIGURE E.1. (contd) 


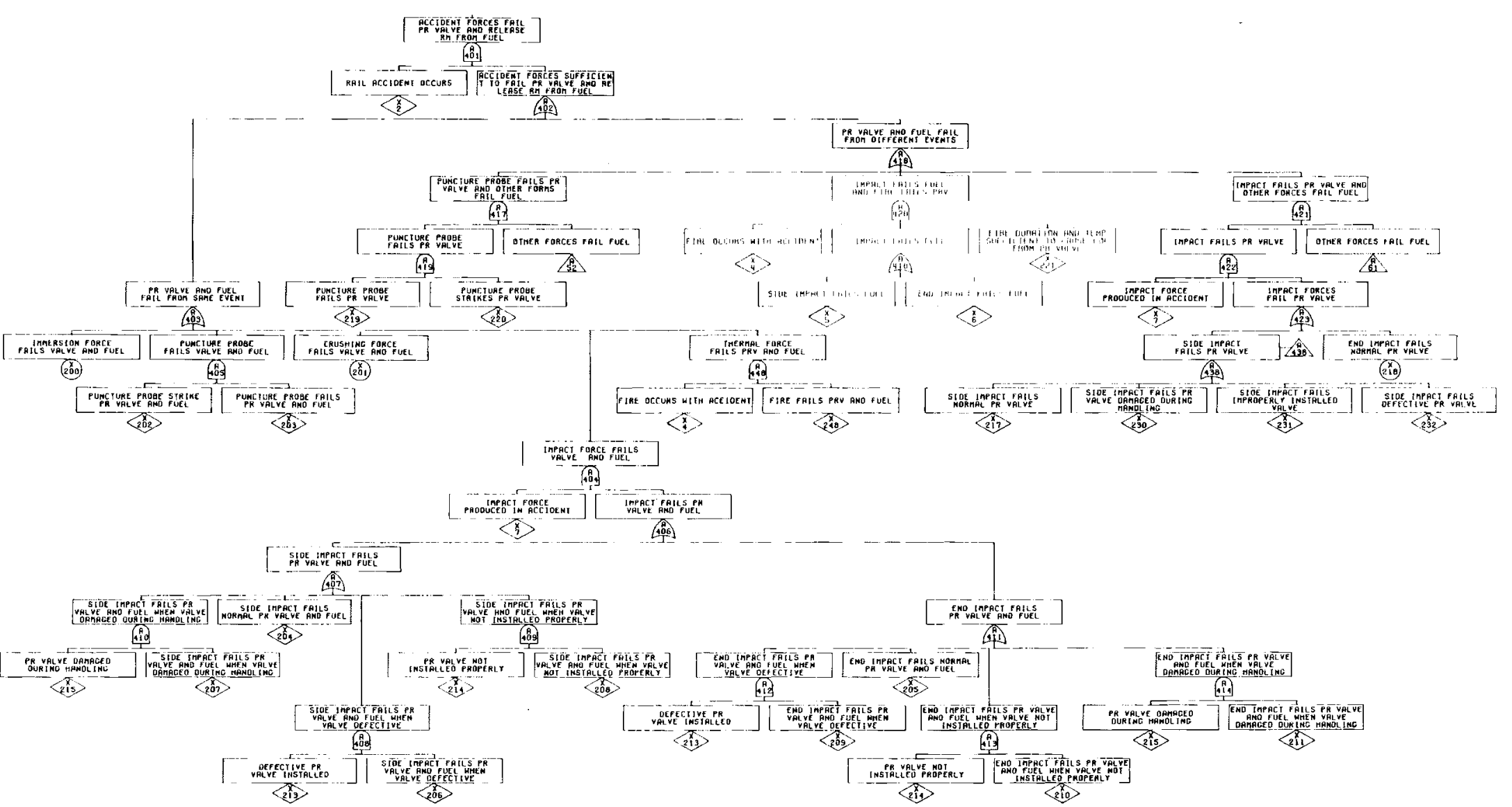

FIGURE E.1. (contd) 
FROM SHEE I

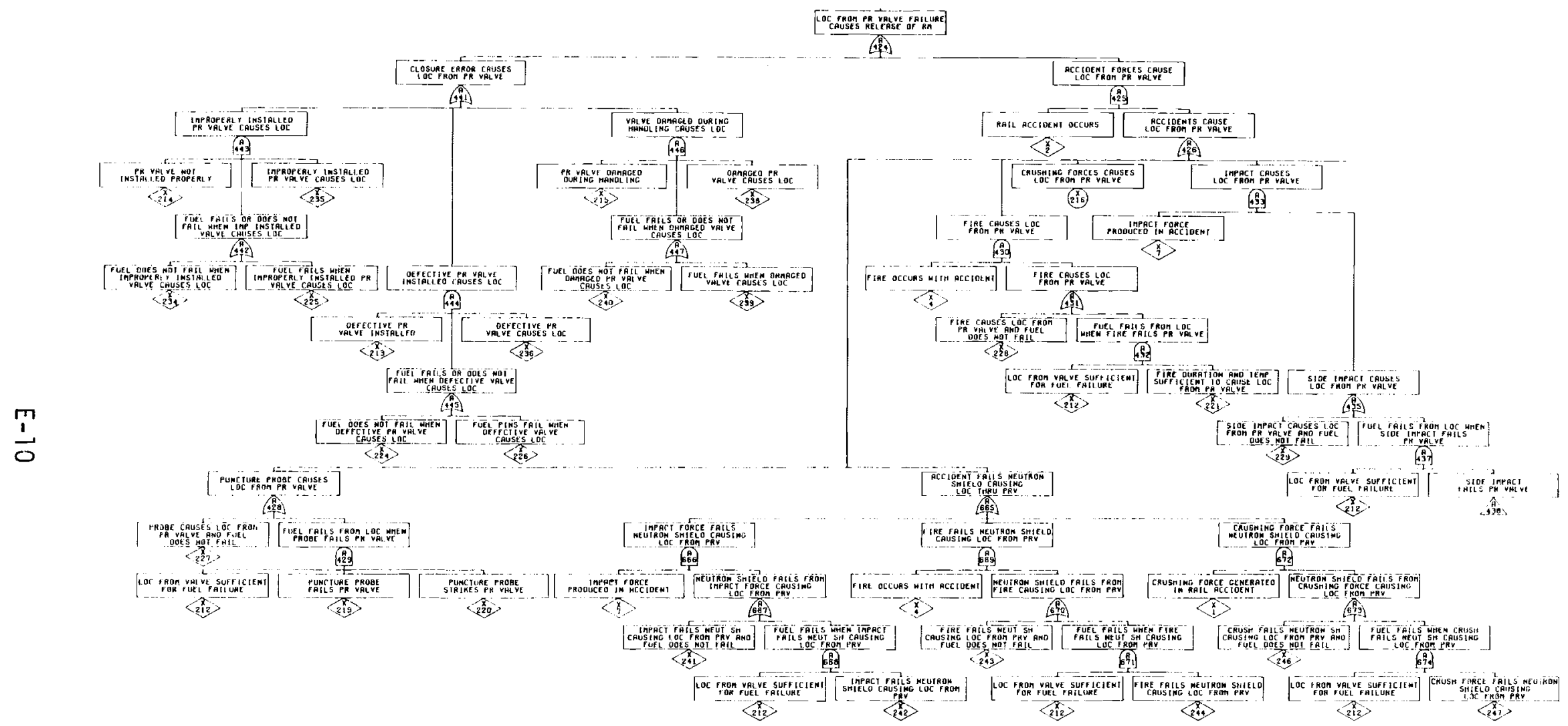

SHEES 9

\section{FIGURE E.1. (contd)}


FROM SHEET 1

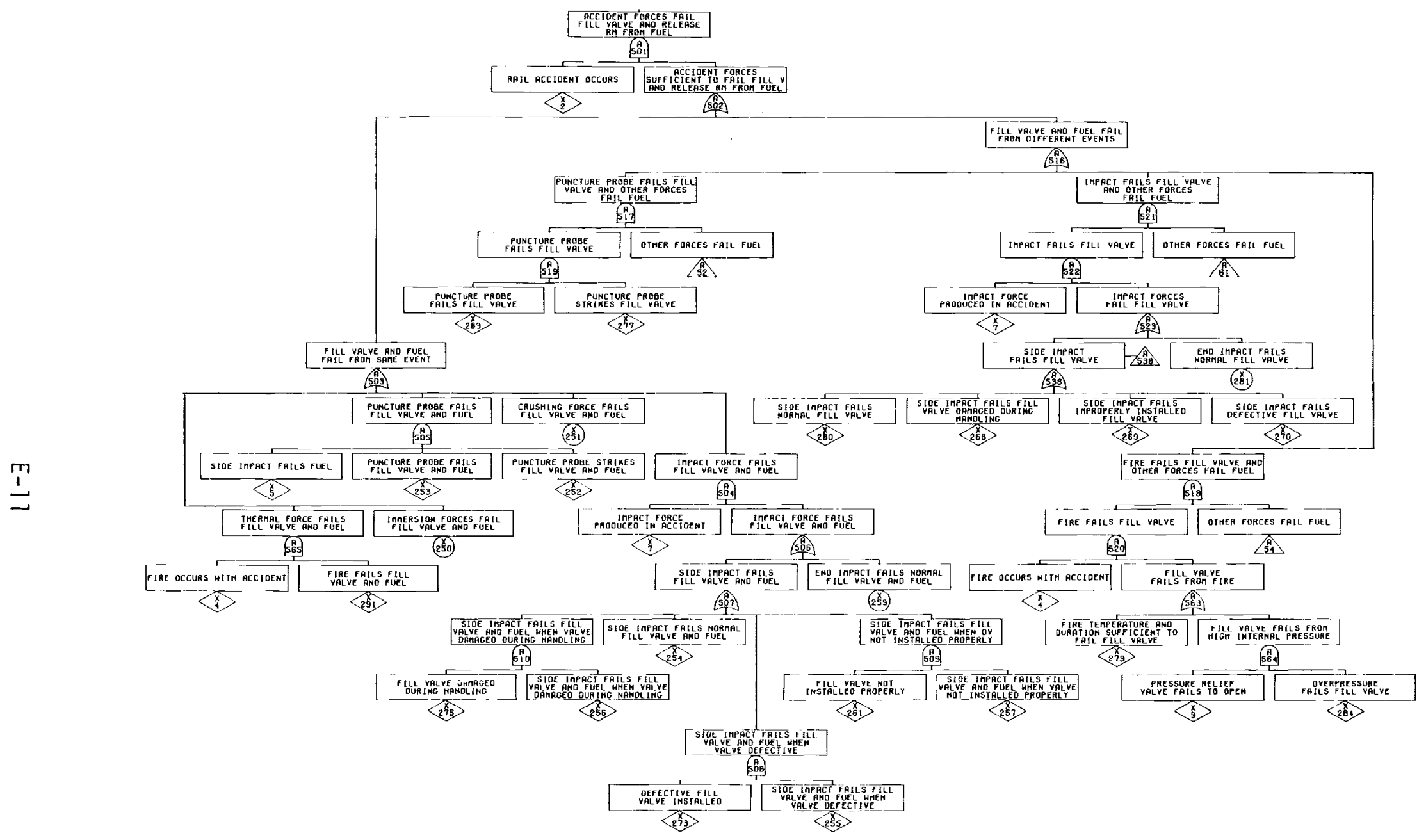

SHEET 10

FIGURE E.l. (contd) 


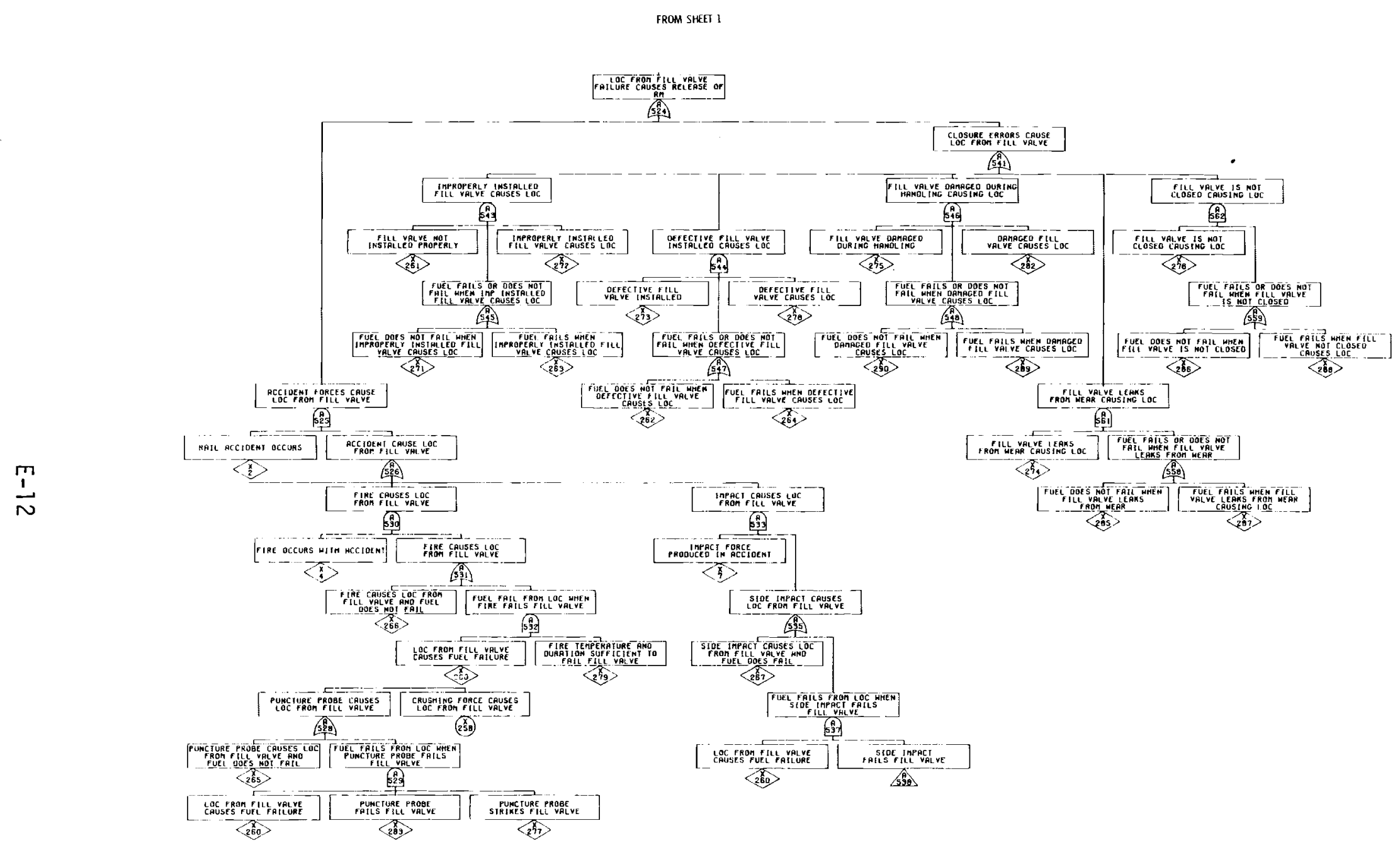

SHET 11

FIGURE E.1. (contd) 


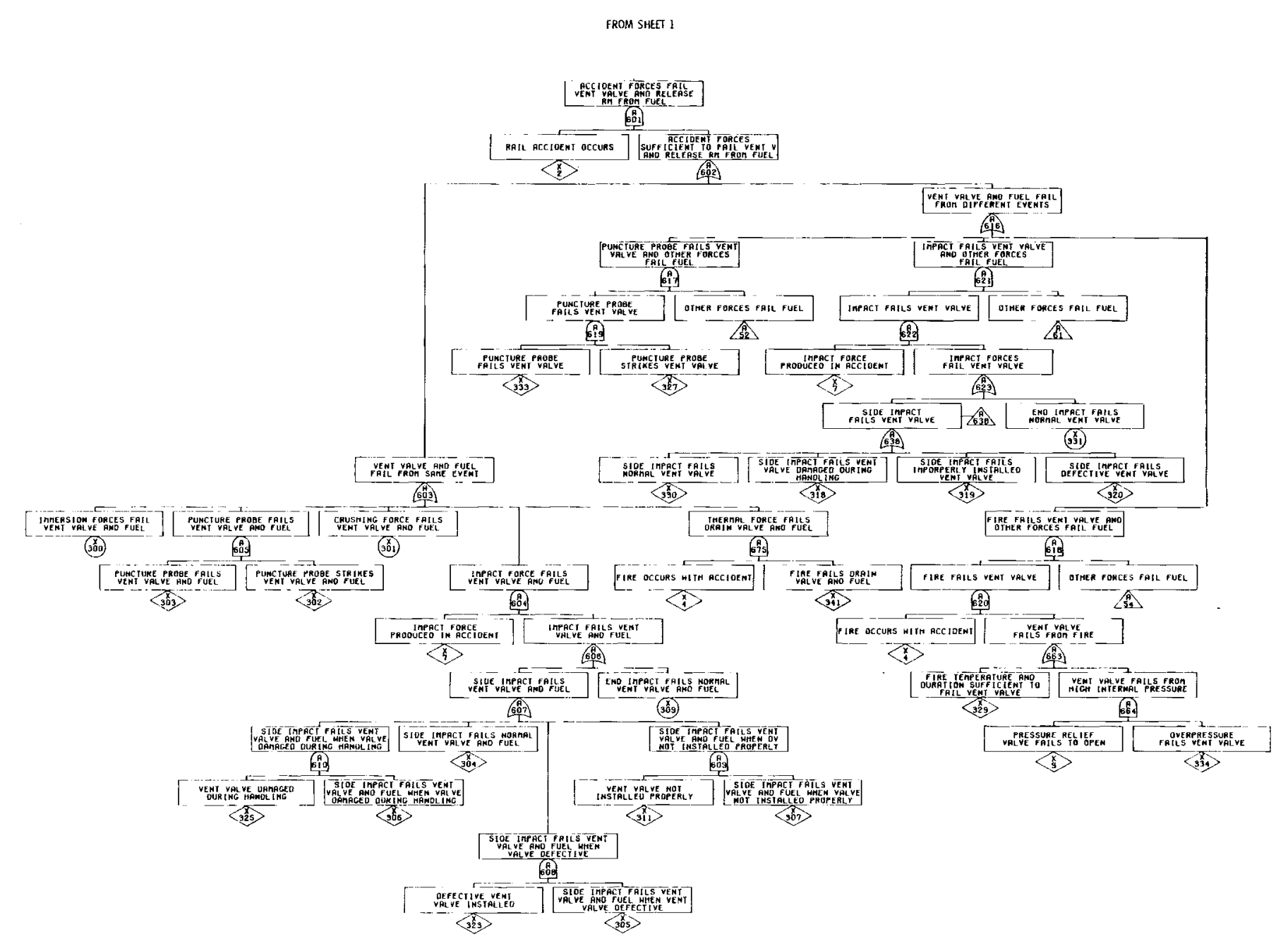




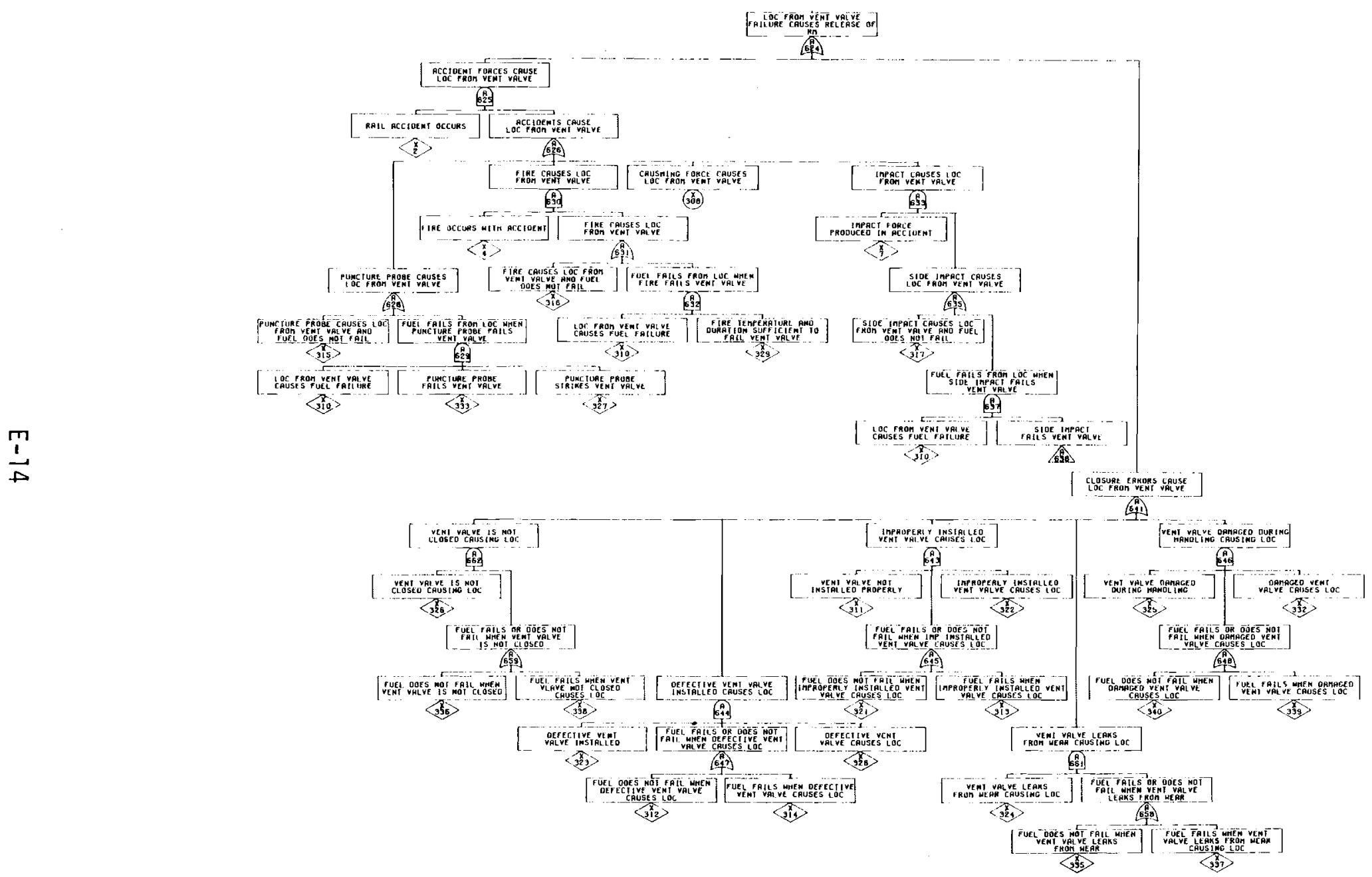

SHEG 13

FIGURE E.1. (contd) 
TABLE E.1. Listing of Basic Events for Analysis of Spent Fuel Shipment by Train

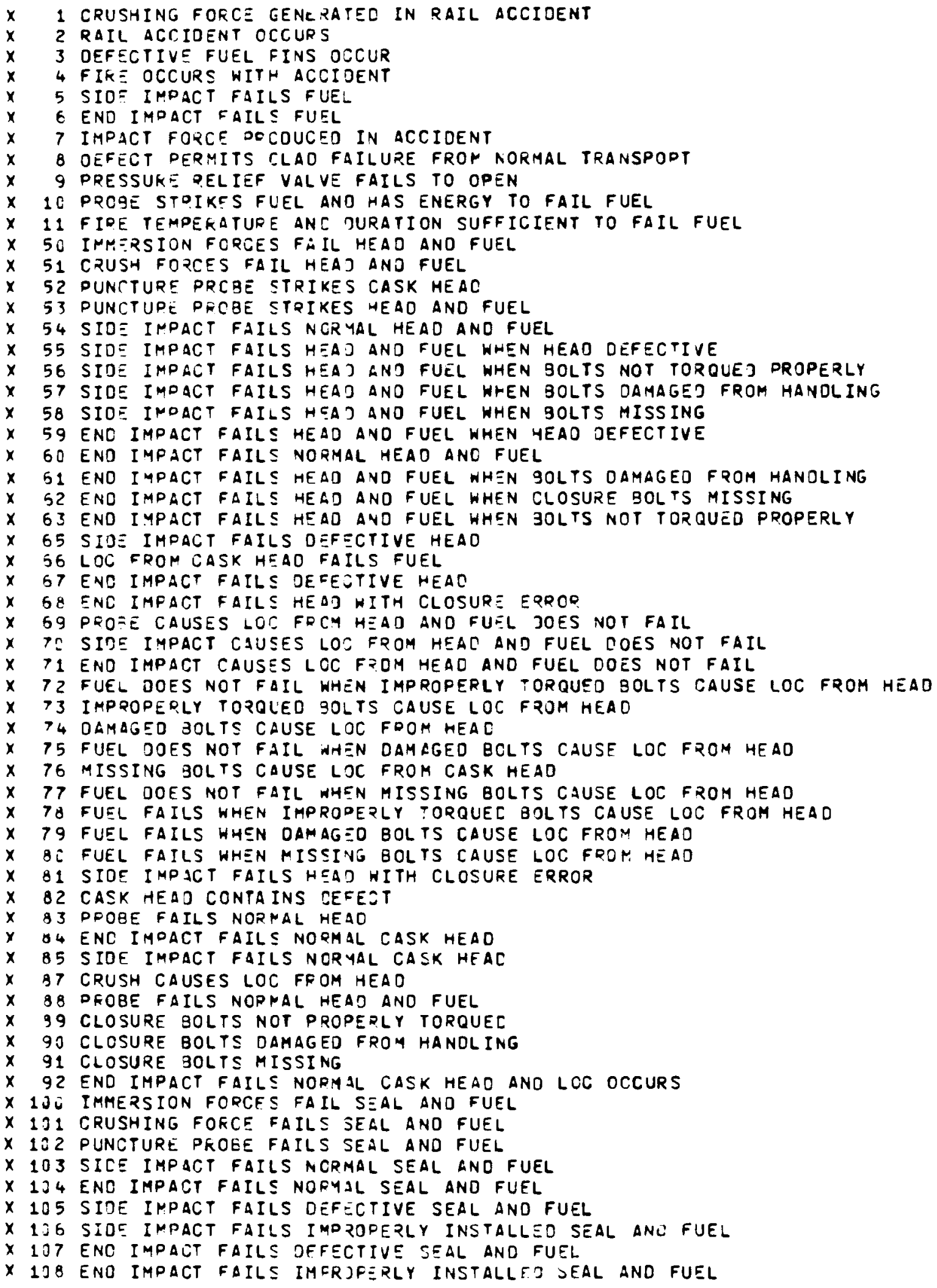




\section{TABLE E. l. (contd)}

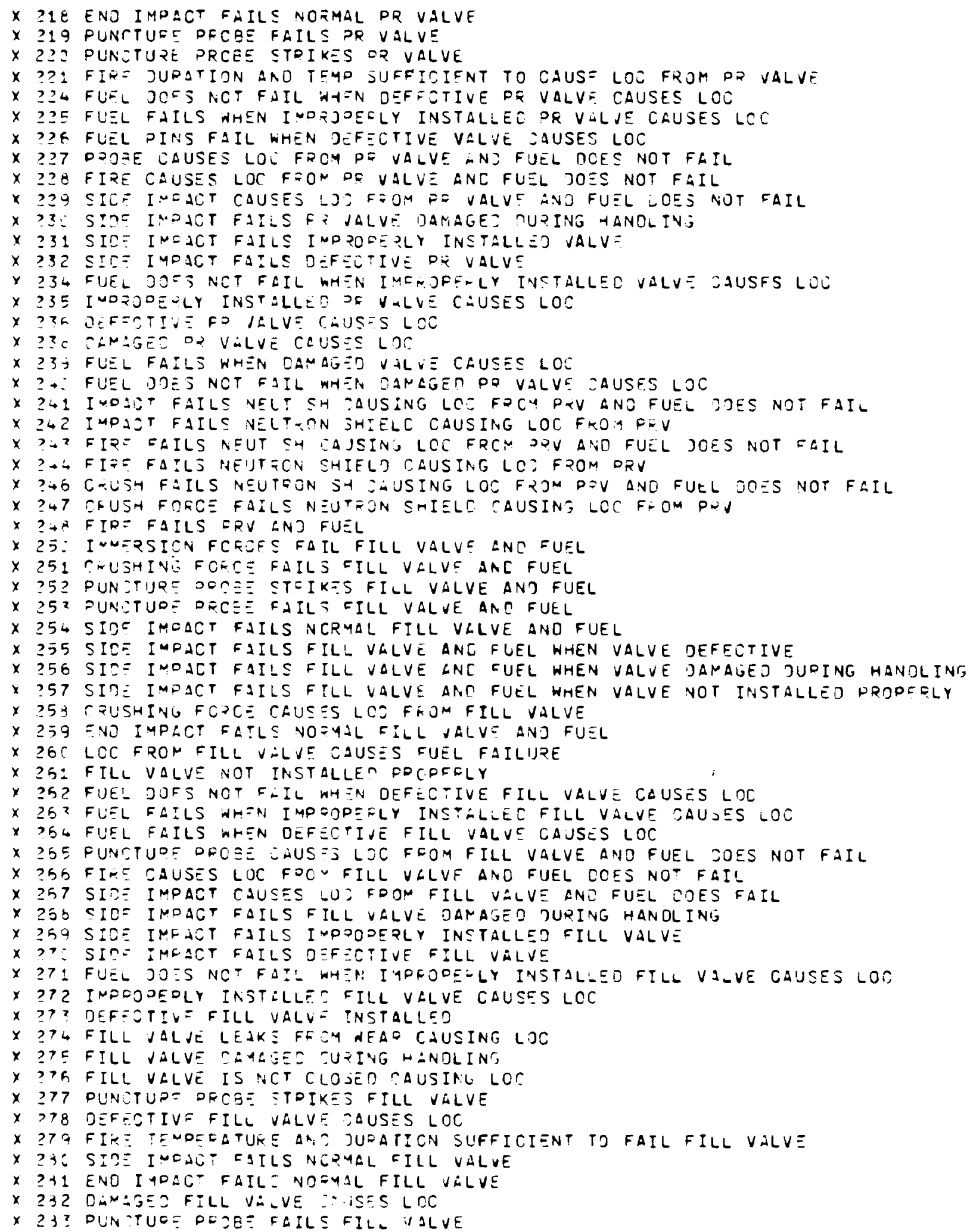




\section{TABLE E. 1. (contd)}

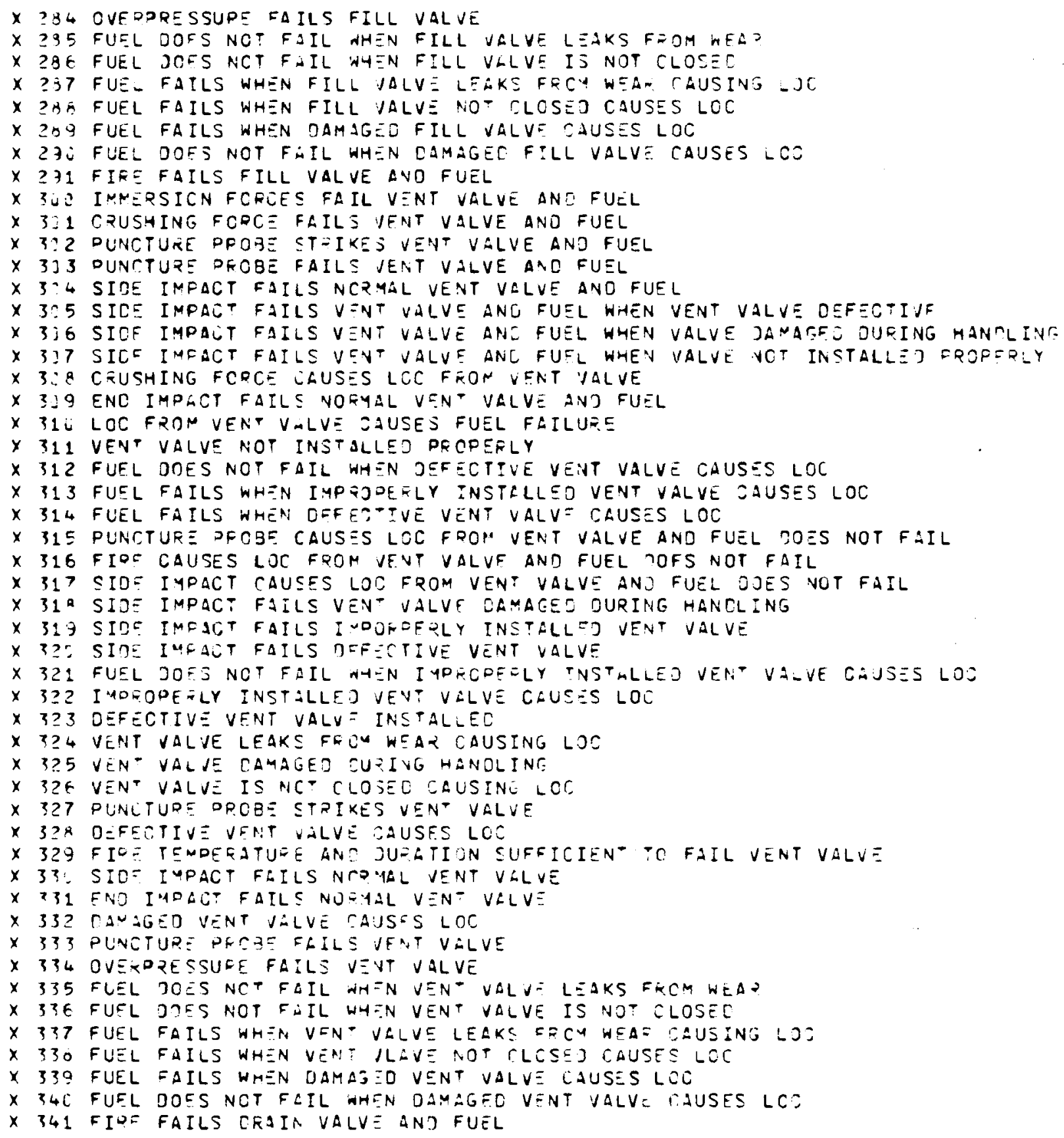


TABLE E.2. Listing of Input Labels for Rectangles for Analysis of Spent Fuel Shipment by Train

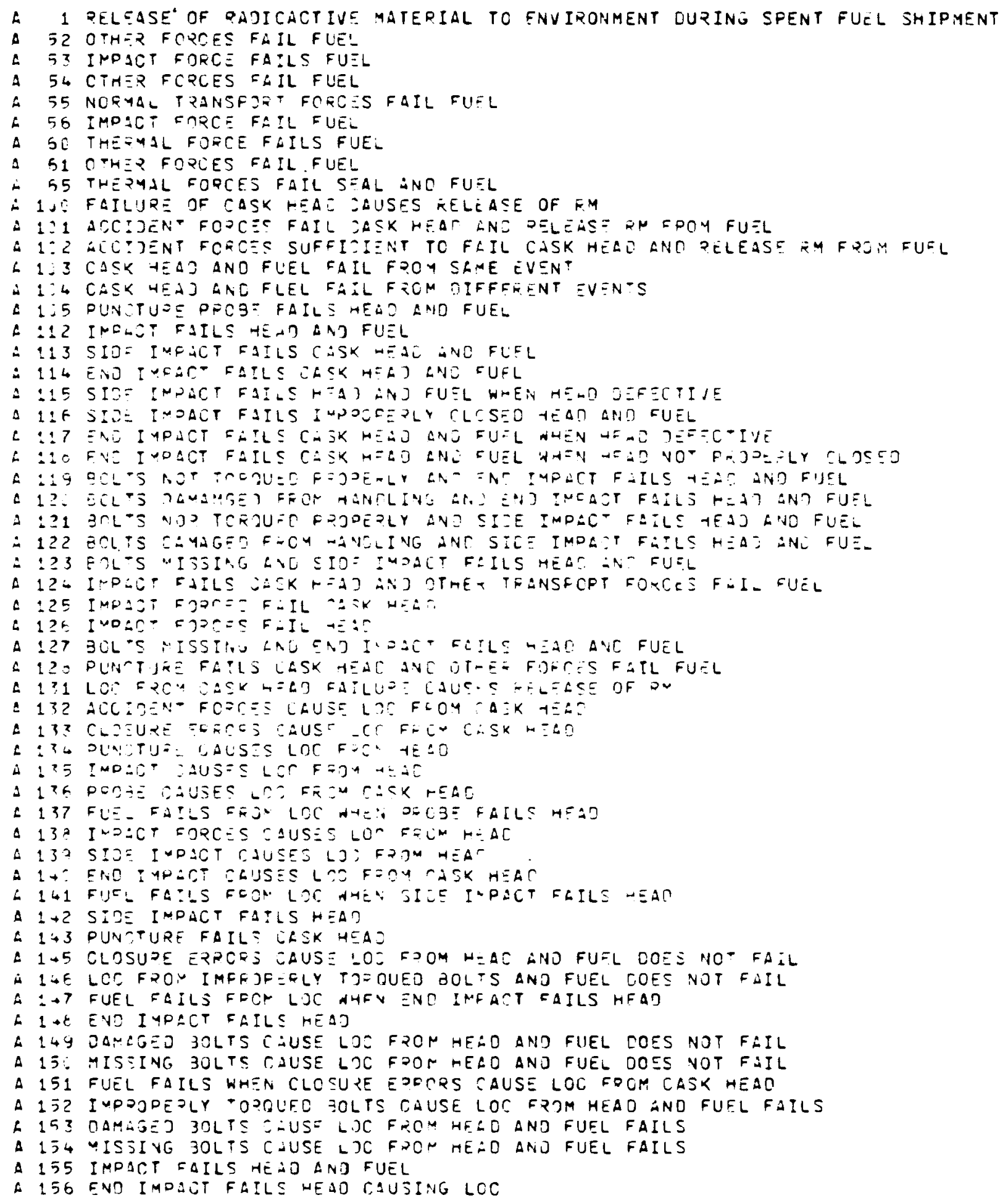


TABLE E.2. (contd)

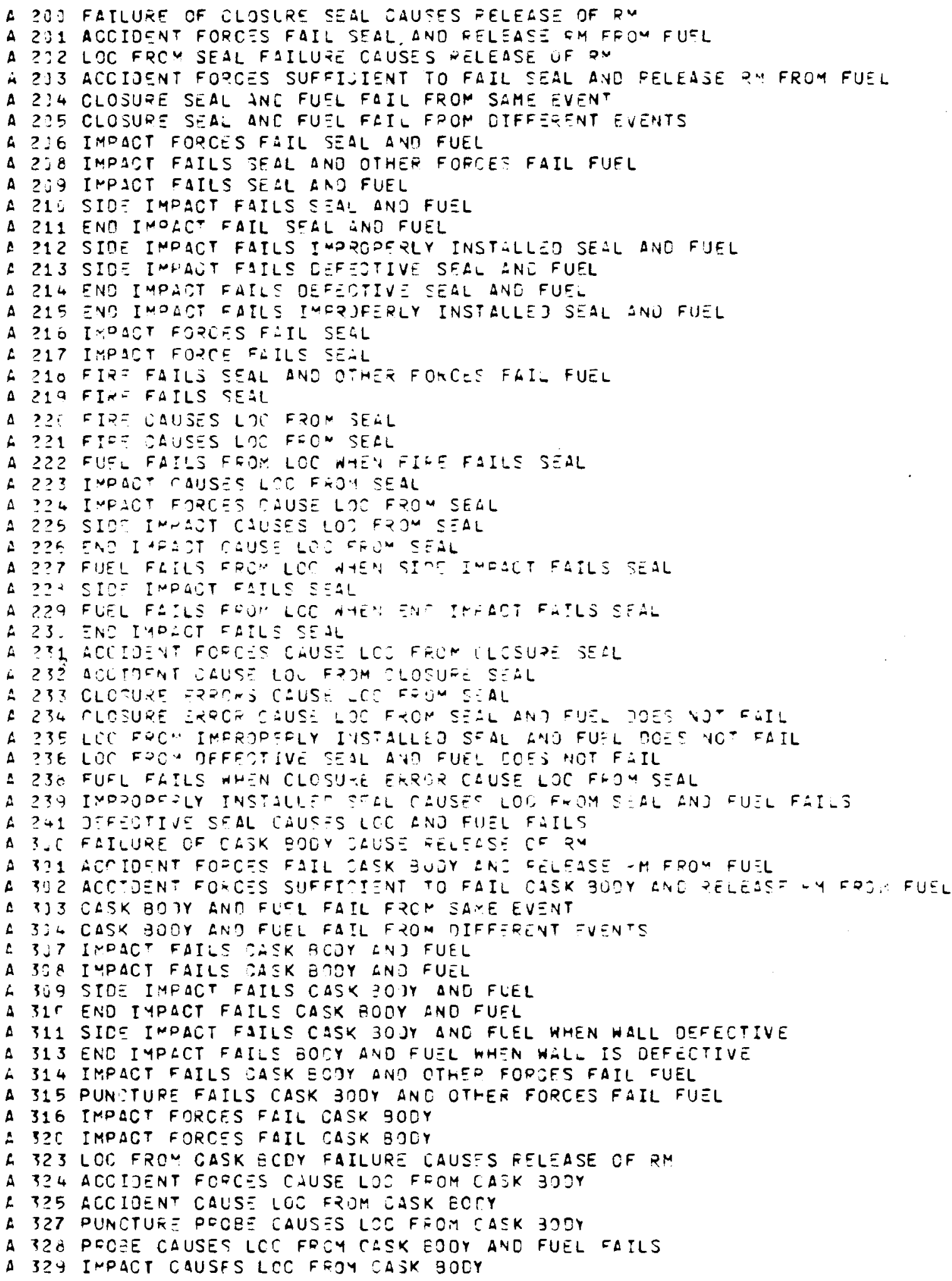


TABLE E.2. (contd)

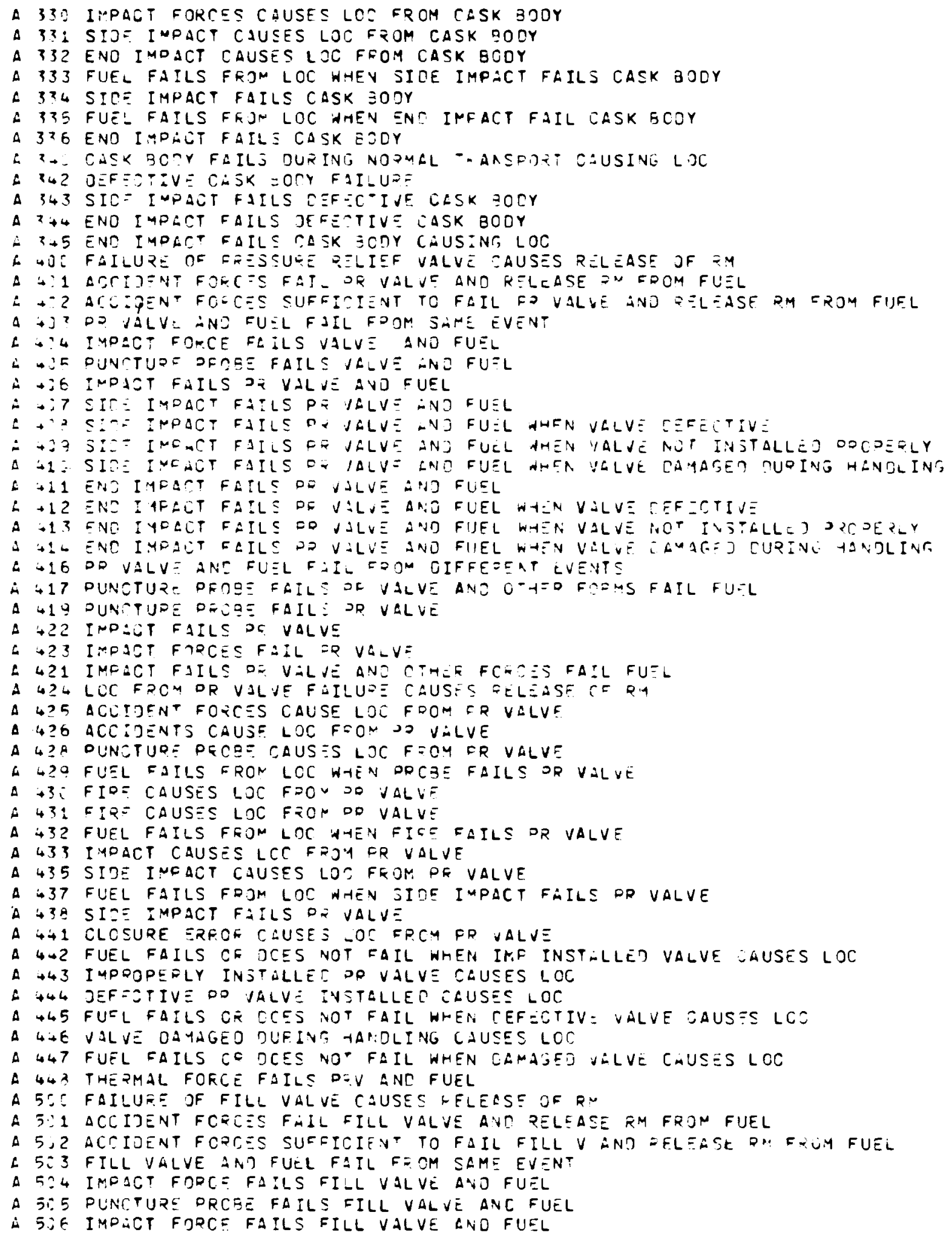


TABLE E.2. (contd)

X 129 FIRE CAUSES LOC FROM JEAL AND FUEL TOES NOT FAIL

$X$ 11: SIDE IMPACT FIILS DEF ECTIVE SEAL

$x 111$ SIDE. IMPACT FAILS SEA- WITH CLOSURE ERROR

$X 112$ END I YOACT FAIL SEAL HITH CLOSUFE ERTOP

$X 113$ ENO IYPACT FAILS DFFEOTTVE SEAL

$X 114$ ENG IMPACT CAUSES LOZ FFOM SEAL AND FUEL LOES NOT FIIL

$x 115$ FIRE OUPATION AND TEMO SUFFICIENT TO FAIL CLCSUPE SEAL

$X 116$ SIOE IMPACT CIUSES LO? FRJM SEAL IND FUFL DOES NOT FAIL

$X 117$ LOL FPOM SEAL SLFFICIFNT TO CAUSE FUFL FAILURE

X 118 SEAL NOT INSTALLEC PROPEQLY

$X 119$ IMPOOPEKLY INST OLLEZ SEAL CAUSES LCC

$x$ 12. FUEL DOES NCT FAIL WHEN I TPFOFEFLY IVSTALLES SEAL CAUSES LOE

$X 121$ FUEL FAILS NHEN IMPOOPEFLY INSTLLLEO SELL CAUSES LOO

$X 122$ CPUSHING FCORE LAUSES LOC FROM SEAL

$X 127$ DEFECTIVE SEAL INSTALLEC

$X 12 J$ DEFECTIVE SEAL CAUSES LCC

$x 120$ FUEL FAILS WHEN DEFEC IVE SEAL CAUSES LOC

$X$ 13: FUEL JDES NCT FAIL WHEN DEFFC IVE SEAL CAUSE LOC

$x I 31$ END ITPOCT FAILS NOOYIL SELL

X 132 SICE INDACT FIILS NCR TAL SELL

$X 133$ THEPMILL FCR:ES FAIL SEIL LN FUEL

$X 15$ IYMTSION FCFEE FAIL ZALK EOJY ENE FUEL

X 151 CFUSA FOOUES FAIL COSK ECOY SHE FLE!

$X 152$ DUNCTUDE DECEE FEILS $\triangle 05 K$ EOJY

X 15? SIOF IMPACT FIILS NCRYAL JLSK EOJY

$\times 154$ SICE IMPACT FAIL FUEL INO JEFET IVE UASK EORY

$X 155$ ENT IMOACT FAILS NOFM AL CASK JCCY

$X: 56$ ENC IYFACT FAILS FUEL AMD JEFETTIVE CASK

$X 157$ SIOE TYFACT FAILS NCR YAL CASK EOOY LNJ FUEL

$X 158$ ENE IMPACT FAILS NOFYAL CASK ECSY ANJ FUEL

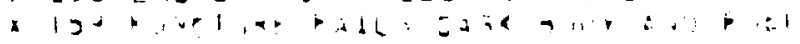

$\times 16:$ D $\approx 03=$ FAILS CASK ENCY CAUSIPG LCC ANJ FUEL OOES NOT FAIL

X 161 SIOE INOACT CAUSE LOE FPOY CASK JOOY AND FUSL JOES NOT FAIL

$X 162$ ENJ IMPACT CAUSES LCL FFOY CASK ZCOY AND FUEL DCES NJ FAIL

$\times 163$ SIEZ IMPACT FAILS DEFEZTIVE CISK EOOY

X 164 TNO IMPAST FAILS DEFESTIVE IASK BCOY

$X 165$ DEFECTIVE WELJ CAUSES LJC OUFINU VORYAL THANSFOCT

X 156 LOC FROM CASK 3COY FAILS FUEL

$X 157$ FUEL DOES NOT F.IL WHEN DEFECTIVE WELO CAUSES LOC

$X 158$ FUEL FAILS WHEN DEFEZTIVE WFL? CALSES LOC

X 159 WELD TO IASK 3OTTOR DEFECTIVF ANC NOT OETECTED

$X$ 17: END IMPACT FAILS NOPYAL CASK BOEY ANJ LOC OCCUFS

$X 171$ ENC IMPQCT FAILS DEFEJTIVE CASK BCCY AND LOC OCCURS

$X$ ?J IMMERSICN FORCE FAILS VALVE ANC FLEL

$x$ ?: 1 CRUSHING FOPCE FAILS VALVE ANO FUEL

$X 222$ PUNLTURE PF.CEE STRIKE PR VALVE INC FUEL

$X$ 2.3 PUNCTURE ORCBE FAILS OP VALVE AND FUEL

$X$ TS 4 SIJE IMOACT FAILS NCRMAL PR VILVE ANO FUEL

$X 2: 5$ END IMPECT FAILS NOFMAL PP VALVE AND FUEL

$x$ ?36 SIDE INFAET FAILS PE VALVE ANJ FUEL WHEN VELVE DEFECTIVE

$X 2 J 7$ SIOE IMPACT FAILS PR VALVE AND FUEL WHEN VILVE CAYAGED OUEING TANDLINS

X 2DA SIDE IMPACT FAILS PF VALVE AND FUEL NHEN VALVE NOT IVSTALLEO DFOFERLY

$X 2 ; 9$ ENC IMPACT FAILS PR VALVE AND FLEL WHEN VALVE DEFECTIVE

$x 21 U$ ENO IMPCCT FAILS DF VALVE ANJ FUEL WTEN VELVE NOT INSTALLEO PEODERLY

$X 211$ ENE IMPACT FAILS PR VILVE ANO FUEL WHEN VALVE LAMAGEJ CURIVE HANJLING

$X 212$ LCC FRON VALVE SUFFICIENT FOR FUEL FAILURE

$X 213$ DEFECTIVE PR VALVE INSTGLLED

$X 214$ DK VALVE VOT INSTALLEJ PROPEPLY

X 215 DK VALVF DAMAGEE CURIVG HANELINE

$X 216$ CQUSHING FOFCES CAUSES LOC FECM PE VALVE

$X 217$ SICF IMPACT FAILS NCRYAL DR VALVE 


\section{TABLE E.2. (contd)}

A 5:T SIDE IMPACT FIILS FILL VALVE ANC FUEL

- 5 S SIO IMOAC? FAILS FILL VALVE ANL FUEL WHEA VALVE JEFETTIJE

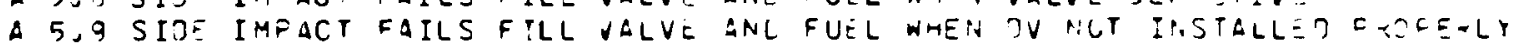

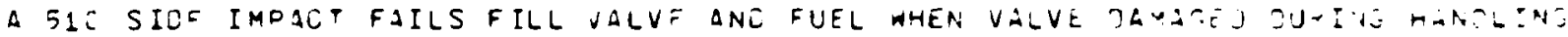

A 516 FILL VALVE QNJ FUEL FIIL FECM CIFFEFEIVT EVERIE

A 517 DUNCTUEE PNCEE FAILS FILL VILVE ANC DTHER FOFUES FL:L FIJEL

A 51H FIFE EAILS FILL VIL JE AVT OTHEF FSPIES FAIL FUEL

A 519 PUN'TURE PFCE三 FAILS EILL VALVE

A 52 FIFF FAILS FILL VILVE

A 521 IMDACT FAILS FILL VALJE AVT OTHER FOPCES FLIL FUEL

A 522 IMD:CT FAILS FILL VALVE

A 523 IMPACT FORCES FAIL EILL VALVE

$\triangle 524$ LOC F2OO FILL VALVE FAILUVE CAUSES - ELEZS= AF FM

A 525 ACCIJEN FCVCES CAUSE LIO FUJV FILL VALVE

A 5?E ACCITENT CAUSE LCT FPIM FILL VILVE

A $52 C$ PUN:TURE PROEZ ZLUSES LZE FFON FILL VALVE

A 5?C FUEL FAILS GOON LOR AHEP OUPCTLIE EFTEE FEILS FILL IALV

A 53: FIE L LUUSES LOR FFUV EILL VILVE

A STI FIKE CAUSES LOC FFC. FILL VILVE

$A=32$ FUFL FLIL F:OA LOC WHEN FIRE FEILS FILL VELVE

2533 INOACT CAUSES LUC F=JA FILL VALVE

$\angle 535$ SIL INEACT CAUSES LO? FE TP FILL VILIE

A $5 \times 7$ FUEL FAILS EROE LOC HAN SIJE IMPACT FAILS FILL JALAE

$\triangle 5$ ?P SILE IUPACT FAILS FILL VALVF

6541 CLOSURE EREDAS TLUSE -OJ FROM FILL VALVE

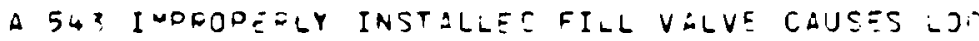

A 5 . OEFECTIV = FILL VALVE INSTALLEJ -ALSESLOC

A 545 FUEL FAILS CD COES NO FAIL WHEI IMF INCTILLES FILL VILVE CEJSES LOS

A 546 FILL VALVE EAYAZEC CUPING NLNOLINE CAUSIN; LOC

A 547 FUEL FA!LS CF CEES NOT FAIL WREA JEFEZTIVE FILL VALVE CIUJES LQE

A 54R FUEL FAILS CF TCES NJT FAIL WHEN ?AMAGE? FiLL VALJE OUUSES LOO

$\triangle$ ¿5\% FUFL FAILS CF CCES NO FAIL WHEN EILL VALVE LEZKS FQJM WEA

$\triangle 559$ FUEL FAILS CR ICES NO TAIL WMEN: FILL VILVE IS NOT GLOSEO

A 551 FILL JALVE LEAKS FESH WEAR CAUSING LJL

A 552 FILL JALVE IS NCT CLOSED TAUSING LOC

A 56? FILL VILVE FAILS FQCY FIRE

A 554 FILL VALVE FAILS FFOM HIGH INTEENAL OOESSURE

A 555 THEEMAL FOPRE FLILS FILL VLLVE ANE FUEL

A 50 FAILURE OF VENT VILVE CLUSES GELEASE JF RM

A 5.1 ACCIOEV FCREEE FAIL JENT VILVE ANO RELEASE PN FRJM FUEL

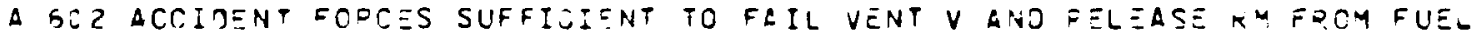

A 503 VENT VALVE ANT FUEL EAIL FOCM SAME EVEN-

A 5:4 IYPACT FORCE FAILS VEYT VILVE IND FUEL

A 5:5 PUNCTURE PPCEE FAIL JEVT VALVE CND FUEL

A 5:6 I YPECT FAILS VENT VELIE AND FUEL

A $5: 7$ SILE IMOACT FAILS VENT VALVE ANE FUEL

4 5! SIOE INDACT FIILS VENT VELVE ANT FUSL WHEN VALVE JEFELTIVE

A SJa SITE IMPACT FIILS VENT VALVE ANE FUEL WHEN CV NOT IVSTALLEO POOCEOLY

A 510 SIOE IMPACT FIILS VENT VELVE ANC FUEL WMEN VALVE JLVATEZ OURINJ HANDLINT,

A SIE VENT VALVE INJ FUEL FGIL FFCM [IFFEFEVT EVENTS

A 517 DUNCTURE PRCE三 FAILS NENT VALVE ANT JTHER FORjES FAIL FUEL

A 518 FIRE FAILS VEVT VALVE ANC OTHEF FCRCES FAIL FUEL

A 619 PUNCTURT POCSE FAILS VEVT VALVE

A 52: FIPE FAILS VEVT VALVE

A Ó21 IMDAC FAILS JENT VALJE ANT OTHER FCPCES FAIL FUEL

A $5 \geq 2$ ITDSCT FAILS JENT VILJE

A $5 ? 3$ IMPSCT FQOCES FAIL VENT VALVE

A 524 LOC FOO. VENT VILVE FIILUPE CAUSES FELEASE JF Q

A 6?5 ACCIJENT FCRCES CAUSE LCC FRCM VEAT JALVE

a 5?6 ACCIDENTS CAUSE LOT FOOM VENT VALVE 


\section{TABLE E.2. (contd)}

A 228 PUNCTURE POCBE CAUSES LOG FROH VEAT VALVE

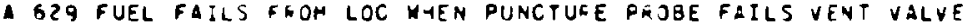

a 630 fire causes loc from vent valve

- 63l fire causes loc from vevt valye

a 632 FUEL FAILS FRON LOC MHEN FIfE FAILS VENT VALVE

a 633 IHPACT CAIJSES LCC FFOA VENT VALVE

A 635 SIDE IMPACT CAUSES LOC FROM VENT VALdE

a 637 FUEL FAILS FRTM LOC WHEY SIDE IMPACT FAILS VENT VALVE

A 638 SICE IMPEST FAILS VENT VALVE

a 641 Closure ERTGF CAUSE loc FoCM VENT VALVE

a 6.3 IMPPOPE-LY INSTALLEJ VENT VILVE CEUSES LOC

A 644 DEFECTIVE VENT VALVE INSTALLEC CAUSES LOC

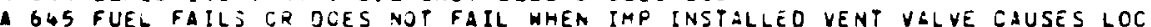

- 646 VENT VALVE CAMAGEj OUzING hanDLING CAUSING LOC

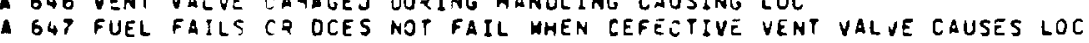

6 64 FUEL FAILS CR DOES NOT FAIL MHEN DAMAGEO VENT VALVE CIUSES LOC

A 658 FUEL FAILS CR DCES NOT FAIL WHEN VENT VALVE LEAKS FROM WEAR

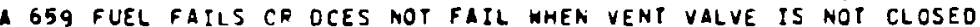

a 661 VENT VALUE LEAKS FROA HEAR CAUSINU LJC

- 662 Vent VAlve is nCt closed causing loc

A 653 VENT VALVE FAILS FROM FIRE

a 56 . VENT VALVE FAILS FRCM HIGH INTEKNAL PRESSURE

a 665 ACCIOENT FAILS NEUTDON SHIELO CAUSINU LCC THFU PRV

- 666 IMPACI FORCF FAILS NEUTRON SHIELD CAUSING LOC FROY PR

- 667 NEUTRON SHIELO FAILS FROM IMPACT FOPCE CAUSING LOC FROM PEV

A 660 FUEL FAILS NHEN IMPACT FAILS NEUT SH CGUSING LOC FROM PEV

A 669 FIRE FAILS NEUTFCN SHIELO CAUSING LOC FROM PRV

A 670 NEUTRON SHIELO FAILS FROA FIRE CAUSING LOL FROM PRV

A 6rI FUEL FAILS HHEN FIRE FAILS NEUT SH CAUSING LOC FROM PAY

- 672 CRUSHING FORCE FAILS NEUTRON SHIELO GAUSING LOC FROH PRY

A 6T3 MEUTRON SHIELD FAILS FROM CRUSHING FJRCE CAUSING LOC FROM PRV

a 674 FUEL FAILS WHEN CRUSH FAILS NEUT SH CAUSING LOC FROM PRV

a 675 thermal force fails orain valve ano fuel 


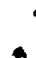




\section{APPENDIX $F$}

\section{BASIC EVENT PROBABILITIES}




\section{APPENDIX $F$}

\section{BASIC EVENT PROBABILITIES}

A sequential description of failure probability estimates for spent fuel shipments in the configuration considered in this risk assessment is presented in this appendix. The number sequence used here corresponds to the numbering sequence used in the fault trees. Events numbered from 1 to 340 are identified in the fault tree shown in Figure E.l of Appendix E. Table E.l lists the events as they are titled and keyed in the fault tree. Since the fault tree is made up of several similar branches, a numbering system was used to help identify the different branches of the tree. Events numbered 1 through 12 identify various basic accident probabilities and fuel failure probabilities. Events which describe failure of the cask lid are numbered 50 through 92 . Those events which are concerned with failure of the closure seal are numbered 100 through 132. Failure events for the cask wall are listed with numbers 150 through 169. Event numbers 200 through 240 are for events covering the pressure relief valve, 250 through 290 for the drain valve and 300 through 340 for the vent valve. The explanation "not used" following an event number simply means that the event number was not used in the numbering sequence.

The expected frequency of the release sequences identified from the fault tree is obtained by taking the product of the probabilities of each event in the sequence. In all cases the best available information was used in determining failure event probabilities. Estimates of the probabilities for each event are presented in the following paragraphs.

Crushing Force Generated in Rail Accident (X1)

The frequency of a spent fuel cask being subjected to a static crushing load during a rail shipment is given in Section 5.4 . The rate of $2 \times 10^{-3}$ per rail car accident was used for this event.

Rail Accident Occurs (X2)

The accident frequency for rail car transport used in this study, which is presented in Section 5.1, is one accident every $160,000 \mathrm{~km}$ or an accident rate 
of $6.2 \times 10^{-6}$ rail car accidents per $\mathrm{km}$. (2) The estimated average shipping distances from Section 4.3 for the two transportation scenarios used in this study are $912 \mathrm{~km}$ and $1030 \mathrm{~km}$. For $912 \mathrm{~km}$ shipping distance, the expected accident frequency is $4.3 \times 10^{-3}$ accidents per shipment and $5.8 \times 10^{-3}$ accidents per shipment for a $1030 \mathrm{~km}$ shipping distance. These values were used in the analysis.

Defective Fuel Pins Occur (X3)

It is conservatively assumed in nuclear reactor plant safety analyses that $1 \%$ of the fuel pins are defective ${ }^{(3)}$ and will leak fission products after reactor operation. Thus it is assumed that some failed fuel will always be present in the cask and the probability of this event was set at 1.0 .

Fire Occurs with Accident (X4)

Based on accident environment data summarized in Section 5.2, the occurrence rate of fire in rail car accidents was estimated to be $2.7 \times 10^{-3}$ fires per rail car accident. (2) It was conservatively assumed that the spent fuel cask was exposed to the fire no more than once in every 10 rail car fire accidents. Thus this event was given the value of $2.7 \times 10^{-4}$ fires per rail car accident which exposes the cask to the fire environment.

Side Impact Fails Fuel Pins (X5)

Mechanical failure thresholds summarized in Section 6 showed that a side impact at a cask velocity greater than $50 \mathrm{kph}$ on a flat unyielding surface would cause failure of the fuel pins. Data summarized in Section 5 , for the accident environment are based on cask-rail car systems and the impact frequency data are based on the transport system impact velocity. For the side impact case, it was assumed that the cask and rail car impact velocities were the same. Data presented in Figure 5.3 showed that the probability of a collision accident resulting in an impact velocity of $50 \mathrm{~km} / \mathrm{hr}$ or greater would be $1.7 \times 10^{-3}$ per rail car accident. From Reference 1 , the probability of a side-on rail impact was shown as $2.1 \times 10^{-2}$. The probability of this event is then $3.6 \times 10^{-5}$ per rail car accident. 
End Impact Fails Fuel Pins (X6)

From Section 6, the fuel pin mechanical failure threshold velocity for end-impact was estimated to be about $70 \mathrm{~km} / \mathrm{hr}$. Full-scale tests performed by Sandia have shown that a rail car system will absorb a certain amount of energy in the system in a collision. Thus the velocity of the rail car could be significantly higher than the cask velocity at impact. For the end impact case, it was conservatively assumed that the cask velocity and the transport system velocity are the same. Data developed by Sandia for the accident environment were based on velocity change of the rail car system, and the impact frequency data were based on transport system impact velocity. Using Figure 5.3, the occurrence frequency for this event was estimated to be $4.0 \times 10^{-4}$ per rail car accident.

Impact Force Produced in Accident (X7)

Data from Sandia summarized in Section 5.3 is based on rail accident statistics which include all collision and derailments involving impact. This event probability is therefore included in the component impact failure threshold probability and this event was given a value of 1.0 .

Defect Permits Clad Failure from Normal Transport (X8)

No data are available for this event. Information on irradiated fuel shipment and storage of more than 200 spent fuel assemblies has shown that no significant leakage from the fuel to the cask coolant occurred and none of the fuel bundles were damaged in transit. (4) occurrence of event $x 8$ is considered to be very unlikely and it was therefore assigned a low probability of $1 \times 10^{-4}$ per shipment. (a)

(a) An analysis was performed to determine the sensitivity of the total release probability to the probability value used for this event. It was found that increasing this event probability by a factor of 10 raised the total release probability by less than 0.01 percent. This is well within the overall accuracy of the analysis. 
Pressure Relief Valve Fails to Open (X9)

It is assumed that the pressure relief valve would open to relieve any excess pressure generated in the cask. Data available in Reference 5 showed a failure rate for relief valves of $1 \times 10^{-5}$ failures per demand. This value was used for component $\times 9$.

Puncture Probe Strikes Cask and Fuel and Has Energy to Fail Fuel (X10)

The probability that a puncture probe will strike the fuel pins was calculated based on the ratio of the projected area of the fuel to the projected area of the spent fuel cask. The rate of occurrence was determined to be 0.63. To fail the fuel pins, a puncture probe would have to penetrate into the cask cavity. Data summarized in Section 5.6 gives the estimated frequency of puncture given a puncture situation in terms of equivalent steel thickness of the container. The reference spent fuel cask has an equivalent steel thickness of about $15.2 \mathrm{~cm}$ (6.0 in.) of mild steel. From this, it was determined that component $\times 10$, the frequency of puncture that could fail the fuel, would be $5.9 \times 10^{12}$ per rail car accident.

(x11) to $(\times 49)$ Not Used

Immersion Forces Fail Cask Head and Fuel (X50)

Failure by immersion is not believed to be significant in accidents involving spent fuel casks. (2) Therefore, this event was not analyzed and was assigned a probability of zero.

Crush Forces Fail Cask Head and Fuel (X51)

Crush forces are not considered to be significant in the transport accident environment of spent fuel casks as described in Section 5.4. (2) This event was therefore given a probability of zero for this analysis.

Puncture Probe Strikes Cask Head (x52)

The probability of a puncture probe striking the cask head was determined by taking the ratio of surface area of the lid to the cask. This gives the percentage of puncture probes that would strike the lid given that the puncture probe strikes the cask. Thus the expected frequency for this event was estimated to be $2 \times 10^{-2}$. 
Puncture Probe Strikes Cask Head and Fuel Pins (X53)

The probability that a puncture probe will strike the cask head and the fuel pins was calculated based on event $X 52$ and the ratio of the projected area of the fuel to the projected area of the spent fuel cask which was determined to be 0.63 . The rate of occurrence of this event was thus $1.3 \times 10^{-2}$. Side Impact Fails Normal Cask Head and Fuel (X54)

Failure threshold data from Table 6.1 show that a velocity change of $72 \mathrm{~km} / \mathrm{hr}$ in a collision onto a rigid planar surface is required to fail the cask 1 id (event $\times 85$ ) and a velocity change of $50 \mathrm{~km} / \mathrm{hr}$ to fail the fuel (event $\times 11$ ). The velocity change required to fail both the 1 id and the fuel would be the same as that to fail the $1 \mathrm{id}, 72 \mathrm{~km} / \mathrm{hr}$. Potential failures from impact with a rigid column were also considered in the failure threshold calculations. Data on the frequency of encountering various impact targets along different types of highway ${ }^{(6)}$ was examined to determine the potential importance of this event. It was found that even though the failure threshold is lower for impact with a rigid column, these failures are not important when compared with impact against a rigid plane because of the infrequent occurrence of large columnar targets along railroad right of way. The probability of this event was then taken to be the same as that for $x 85,3.9 \times 10^{-4}$.

Side Impact Fails Cask Head and Fuel When Head Defective (X55)

The probability of a side impact failing both the fuel and a defective cask head was estimated to be twice as likely as the probability of failing a normal head and fuel. Thus a value of $1.2 \times 10^{-5}$ was used for this event. (a)

(a) An analysis was performed to determine the sensitivity of the total release probability to the probability value used for this event. It was found that increasing this event probability by a factor of 10 raised the total release probability by less than $0.01 \%$. This is well within the overall accuracy of the analysis. 
Side Impact Fails Head and Fuel When Bolts Not Torqued Properly (X56)

The probability of a side impact failing both the fuel and cask head with bolts not torqued properly was estimated to be twice as likely as the probability of failing a normal head and fuel. Thus a value of $1.2 \times 10^{-5}$ was used for this event. (a)

Side Impact Fails Cask Head and Fuel When Bolts Damaged From Handling (X57)

The probability of a side impact failing both fuel and the 1 id with damaged bolts was estimated to be two times more probable than failing a normal 1 id and fuel (event $\times 54$ ). This event was assigned a value of $1.2 \times 10^{-4}$ (a) Side Impact Fails Cask Head and Fuel When Bolts Missing (X58)

The probability of a side impact failing both fuel and the lid with bolts missing was estimated to be twice as likely as failing a normal lid and fuel (event 54). This event was then given a value of $1.2 \times 10^{-5}$. (a)

End Impact Fails Cask Head and Fuel When Lid Defective (X59)

The probability of an end impact failing the fuel and a defective lid was estimated to be two times more likely than the probability of failing a normal 1 id and fuel (event $\times 60$ ). Event $\times 59$ was therefore given a value of $2.0 \times 10^{-5}$ (a)

End Impact Fails Normal Cask Head and Fuel (X60)

Failure threshold data from Figure 5.3 show a velocity change of $81 \mathrm{~km} / \mathrm{hr}$ to fail the cask lid and $70 \mathrm{~km} / \mathrm{hr}$ for the fuel. Thus a velocity change of $81 \mathrm{~km} / \mathrm{hr}$ would be required to fail both the lid and fuel. The probability of this event was then taken to be $1.0 \times 10^{-5}$.

(a) An analysis was performed to determine the sensitivity of the total release probability to the probability value used for this event. It was found that increasing this event probability by a factor of 10 raised the total release probability by less than $0.1 \%$. This is well within the overall accuracy of the analysis. 
End Impact Fails Cask Head and Fuel When Bolts Damaged from Handling (X61)

The probability of an end impact failing the fuel and a lid with damaged bolts was estimated to be two times more likely to occur than a normal 1 id. The probability of event $\times 61$ was then taken to be $2.0 \times 10^{-5}$ (a)

End Impact Fails Cask Head and Fuel When Closure Bolts Missing (X62)

An end impact causing failure of the fuel and lid with bolts missing was estimated to occur twice as frequently as a normal 1id. The probability of this event was then estimated to be $2.0 \times 10^{-5}$ (a)

End Impact Fails Cask Head and Fuel When Bolts Not Torqued Properly (X63)

An end impact causing failure of the fuel and lid with bolts not properly torqued was assumed to occur twice as frequently as a normal 1id. The probability of the event was then estimated to be $2.0 \times 10^{-5}$ (a)

(X64) Not Used

Side Impact Fails Defective Cask Head (X65)

The probability of a side impact failing a defective lid was estimated to be two times more probable than the likelihood of failing a normal 1 id event (X85). Quality control in manufacturing operations is estimated to have a probability of $3 \times 10^{-3}$ that a defective component will not be detected. It is assumed that this value is representative of the probability that the cask 1 id contains a defect which could effect the impact strength. Thus a value of $1.7 \times 10^{-6}$ was used for this event. (a)

Loss of Coolant from Cask Head Fails Fuel (X66)

If a loss of cavity coolant occurs and no action is taken to restore the coolant, fuel cladding failures will occur from self-heating of the fuel elements. This is shown in the thermal analysis summarized in Section 6.2. If a coolant loss occurs it is shown in Table 6.3 that it would take about

(a) An analysis was performed to determine the sensitivity of the total release probability to the probability value used for this event. It was found that increasing this event probability by a factor of 10 raised the total release probability by less than $0.1 \%$. This is well within the overall accuracy of the analysis. 
5 hours until fuel failure starts to occur. If coolant was restored during that time, no fuel would fail and only the cavity coolant activity or fuel which was damaged initially in the accident would be released. Since there is not data available to determine the probability of restoring the cavity coolant, the probability of fuel pin failure was set at 0.5 given that a loss of coolant occurs.

\section{End Impact Force Fails Defective Cask Head (X67)}

The probability of an impact force failing a defective lid was estimated to be two times more probable than the impact force to fail a standard cask 1id. The probability of a defective lid which could affect the impact strength is assumed to be $3.0 \times 10^{-3}$ (see event $\times 65$ ). Thus the probability that an impact force would fail a defective cask lid was estimated to be $3.0 \times 10^{-8}$ per rail car accident based on the value used for $\times 84$. (a)

\section{End Impact Fails Cask Head with Closure Error (X68)}

A probability of $1.0 \times 10^{-5}$ was used for an end impact failing a normal cask head (see event $\times 84$ ). The probability of a closure error is estimated to be $1.5 \times 10^{-3}$ (see event $\times 89$ ). Therefore the probability of this event was estimated to be $1.5 \times 10^{-8}$. (a)

Puncture Probe Causes LOC from Cask Head and Fuel Does Not Fail (X69)

A puncture probe causing a loss of coolant was determined in event $x 83$ to have a probability of $5.9 \times 10^{-12}$. The thermal analysis summarized in Section 6 shows that when cavity coolant is lost it takes approximately two hours before fuel pin failure starts to occur. If coolant is restored before two hours has elapsed, then fuel failure would te prevented and only coolant activity would be released. No data is available to estimate the probability of restoring the coolant, so a conservative value of 0.1 was assumed for this occurrence. Thus event $x 69$ was assigned a value of $5.9 \times 10^{-13}$.

(a) An analysis was performed to determine the sensitivity of the total release probability to the probability value used for this event. It was found that increasing this event probability by a factor of 10 raised the total release probability by less than $0.1 \%$. This is well within the overall accuracy of the analysis. 
Side Impact Causes LOC from Cask Head and Fuel Does Not Fail (X70)

A side impact causing a loss of coolant determined for event $\times 85$ to have a probability of $5.9 \times 10^{-6}$. A probability of 0.1 was used for the estimated frequency of restoring the coolant (see event $\times 69$ ). This event was then assigned a value of $5.9 \times 10^{-7}$.

End Impact Causes LOC from Cask Head and Fuel Does Not Fail (X71)

The probability of an end impact causing a loss of coolant taken from event $\times 84$ is $1.0 \times 10^{-5}$. A probability of 0.1 was used for the probability of restoring the coolant (see event $\times 69$ ). This event was given a value of $1.0 \times 10^{-6}$.

Fuel Does Not Fail When Improperly Torqued Bolts Cause LOC from Cask Head (X72)

The probability of fuel failure when improperly torqued bolts cause loss of coolant from the lid is $3 \times 10^{-3}$ (see event $\times 78$ ). The probability that the fuel does not fail is one minus the failure probability. This event was thus assigned a value of 1.0 .

Improperly Torqued Bolts Cause LOC from Cask Head (X73)

Data for event $X 89$ gives the frequency of occurrence of improperly torqued bolts, but does not indicate that leakage occurred. It was conservatively assumied that $1 \%$ of those failures would result in significant leakage. Thus the rate for event $X 73$ was set at $1.0 \times 10^{-2}$ per cask shipment. (a)

Damaged Bolts Cause LOC from Cask Head (X74)

Failure of closure bolts in handling does not indicate that release of coolant would occur. It was conservatively assumed that $1 \%$ of the failures would result in a significant release. Thus event $X 74$ was given a value of $1.0 \times 10^{-2(a)}$.

(a) An analysis was performed to determine the sensitivity of the total release probability to the probability value used for this event. It was found that increasing this event probability by a factor of 10 raised the total release probability by less than $0.1 \%$. This is well within the overall accuracy of the analysis. 
Fuel Does Not Fail When Damaged Bolts Cause LOC from Cask Head (X75)

A probability of 1.0 was used for this event (see event $\times 72$ ).

Missing Closure Bolts Cause LOC from Cask Head (X76)

The fact that some closure bolts were missing in the survey does not indicate that leakage would occur. It was conservatively assumed that $1 \%$ of the failures would result in leakage. This event was therefore given a value of $1.0 \times 10^{-2}$. (a)

Fuel Does Not Fail When Missing Closure Bolts Cause LOC from Cask Head (X77)

A probability of 1.0 was used for this event (see event $\times 72$ ).

Fuel Fails when Improperly Torqued Bolts Cause LOC from Cask Head (X78)

Calculations in Appendix $D$ on thermal analysis show that approximately 5 hours after a loss of coolant, fuel clad failure will start to occur due to creep rupture. For fuel failure to occur the leakage must not be detected and measures must not be taken to prevent loss of coolant or to restore the coolant. Human failure rate data from Reference 5 show that errors of human omission have an estimated rate of $3 \times 10^{-3}$. It is very conservatively assumed for this event that after coolant is lost, it is not restored. A value of $3.0 \times 10^{-3}$ failures per cask shipment was used for this event.

Fuel Fails When Damaged Bolts Cause LOC from Cask Head (X79)

A probability of $3.0 \times 10^{-3}$ per shipment was used for this event (see event $\times 78)$.

Fuel Fails When Missing Bolts Cause LOC from Cask Head (X80)

A probability of $3.0 \times 10^{-3}$ per shipment was used for this event (see event $\mathrm{X78)}$.

(a) An analysis was performed to determine the sensitivity of the total release probability to the probability value used for this event. It was found that increasing this event probability by a factor of 10 raised the total release probability by less than $0.1 \%$. This is well within the overall accuracy of the analysis. 
Side Impact Fails Cask Head with Closure Error (X81)

The probability of a side impact failing a cask head with a closure error is estimated to be two times more probable than the likelihood of failing a normal cask head (event $\times 85$ ). The probability of a closure error is assumed to be $1.5 \times 10^{-3}$ (see event $\times 89$ ). Thus, a value of $8.8 \times 10^{-9}$ was used for event $x 81 .(a)$

Cask Head Contains Defect (X82)

Leak and rupture assessments for passive hardware in Reference 5 show that the probability of failure for a flange or large pipe is on the order of $10^{-8}$ per hour of operation. Assuming that an average trip takes one day, the probability of a cask head defect large enough to allow a release (event $\times 82$ ) was given a value of $5 \times 10^{-7}$ per shipment.

Puncture Probe Fails Normal Cask Head (X83)

Based on data presented in Figure 5.5, the estimated frequency of puncture to fail the cask head, assuming an equivalent stee 1 thickness of 6.0 inches, was estimated to be $5.9 \times 10^{-12}$ per rail car accident.

End Impact Fails Normal Cask Head (X84)

From Section 6, the velocity change for the cask head in the end impact case resulting in a large breach of the head was estimated to be about $105 \mathrm{~km} / \mathrm{hr}$ (see Table 6.1). Based on a 163-megagram rail car-cask system, the probability that a cask head will experience impact forces exceeding $105 \mathrm{~km} / \mathrm{hr}$ velocity change was estimated to be less that $1.0 \times 10^{-5}$ per rail car accident. Therefore, this event was estimated to have a frequency of $1.0 \times 10^{-5}$ per rail car accident for a large breach of the cask head.

Side Impact Fails Normal Cask Head (X85)

Failure threshold data summarized in Table 6.1 show that a velocity change of $76 \mathrm{~km} / \mathrm{hr}$ is required to cause a failure of the cask in a side impact onto a

(a) An analysis was performed to determine the sensitivity of the total release probability to the probability value used for this event. It was found that increasing this event probability by a factor of 10 raised the total release probability by less than $0.1 \%$. This is well within the overall accuracy of the analysis. 
flat surface. It is assumed that the cask head would fail at that impact velocity. From Reference 1, the probability that the cask will be accelerated perpendicular to its axis is $2.1 \times 10^{-2}$. This is taken as the probability of a side-on impact. The probability of a velocity change of $76 \mathrm{~km} / \mathrm{hr}$ or greater in a collision accident, as given in Figure 5.4 , is $2.8 \times 10^{-4}$. The probability of this event is then $5.9 \times 10^{-6}$ per rail car accident.

(X86) Not Used

Crushing Force Causes LOC from Cask Head (X87)

Crush forces are not considered to be significant in the transport accident environment, as discussed in Section 5.4. This event was given a probability of zero for this analysis.

Puncture Probe Fails Normal Cask Head and Fuel (X88)

The probability of a probe failing the cask lid (event $\times 83$ ) was estimated to be about $10^{-12}$ to $10^{-16}$. If the failures are totally dependent, the combined failure rate would be $10^{-12}$. It is assumed for this event that the probability of a puncture probe causing failure of both lid and fuel was $1.0 \times 10^{-13}$.

Closure Bolts Not Properly Torqued (X89)

Data obtained from the survey of spent fuel shipments indicated that a frequency of $1.5 \times 10^{-3}$ per cask shipment occurred for this event. The occurrence rate assumed for element $X 89$ was then $1.5 \times 10^{-3}$ per cask shipment.

Closure Bolts Damaged from Handling ( $\times 90)$

No incidence of closure bolt damage was included in the survey. Based on a $50 \%$ confidence level for the sample size involved, this packaging error rate was estimated to be $9.7 \times 10^{-4}$ per cask shipment. Thus, element $\times 90$ was assumed to have a rate of $9.7 \times 10^{-4}$ per cask shipment.

Closure Bolts Missing ( $\times 91)$

Data from the survey indicated a frequency for missing bolts of $2.8 \times 10^{-4}$ per cask shipment occurred. Based on a $50 \%$ confidence level, the value of this event was estimated to be $2.4 \times 10^{-3}$ per cask shipment. 
End Impact Fails Normal Cask Head Resulting in LOC (X92)

From Section 6, the velocity change for the cask 1 id in the end impact case resulting in loss of coolant was estimated to be about $80 \mathrm{~km} / \mathrm{hr}$. From Figure 5.4, the probability that a cask 1 id will experience impact forces of $80 \mathrm{~km} / \mathrm{hr}$ or greater was estimated to be $1.5 \times 10^{-4}$ per rail car accident. (X93) to (X99) Not Used

Immersion Forces Fail Seal and Fuel (X100)

A probability of zero was used for this event (see event $\times 50$ ).

Crushing Force Fails Seal and Fuel (X101)

A probability of zero was used for this event (see event $\times 51$ ).

Puncture Probe Fails Seal and Fuel (X102)

The probability of a puncture probe failing both the seal and fuel was not believed to be significant. Therefore, the event was not analyzed and was assigned a probability of zero.

Side Impact Fails Normal Seal and Fuel (X103)

A velocity change of $72 \mathrm{~km} / \mathrm{hr}$ is required to fail the seal in a side impact and $50 \mathrm{~km} / \mathrm{hr}$ to fail the fuel. The velocity change required to fail both the seal and fuel would be $72 \mathrm{~km} / \mathrm{hr}$. From event $\times 132$, the probability of failure for a $72 \mathrm{~km} / \mathrm{hr}$ velocity change is $5.9 \times 10^{-6}$ per rail car accident. This value was used for event $X 103$.

End Impact Fails Norma 1 Sea 1 and Fue1 (X104)

A velocity change of $80 \mathrm{~km} / \mathrm{hr}$ is required to fail the seal in an end impact and $70 \mathrm{~km} / \mathrm{hr}$ to fail the fuel. Thus, a velocity change of $80 \mathrm{~km} / \mathrm{hr}$ would be required to fail both seal and fuel. The probability for this event was then assumed to be $1.5 \times 10^{-4}$, based on data in Figure 5.4. 
Side Impact Fails Defective Seal and Fuel (X105)

A side impact failure of both the fuel and a defective seal was estimated to be twice the probability of failing a normal seal (event $\times 103$ ). A value of $1.2 \times 10^{-5}$ rail car accident was used for this event. (a)

Side Impact Fails Improperly Installed Seal and Fuel (X106)

This event was assigned a probability of $1.2 \times 10^{-5}$ (see event $\left.\times 105\right)$. (a) End Impact Fails Defective Seal and Fuel (X107)

An end impact which failed both the fuel and a defective seal was estimated to be twice as probable as a normal seal (event $\times 104$ ). A value of $3.0 \times 10^{-4}$ failures per rail car accident was used for this event. (a) End Impact Fails Improperly Installed Seal and Fuel (x108)

This event was given a probability of $3.0 \times 10^{-4}$ (see event $\times 107$ ). (a) Fire Causes LOC from Seal and Fuel Does Not Fail (X109)

A fire causing a failure of the seal with loss of coolant and fuel failure was determined to have a probability of $5.0 \times 10^{-4}$ per rail car accident (in event $\times 115$ ). A value of 0.1 is estimated for the probability of restoring coolant following an accident (see event $\times 69$ ). This event was therefore assigned a probability of $5.0 \times 10^{-5}$ per rail car accident.

Side Impact Fails Defective Seal (X110)

It is assumed that a defective seal would fail from side impact twice as frequently as a normal seal (event $\times 132$ ). The probability that a closure seal will have a defect that affects the impact failure threshold is taken to be the same as the probability of installing a defective seal. A value of $3.0 \times 10^{-3}$ is used (see event $\times 127$ ). Thus, a value of $3.6 \times 10^{-8}$ failures per rail car accident was used for event $\times 110$. (a)

(a) An analysis was performed to determine the sensitivity of the total release probability to the probability value used for this event. It was found that increasing this event probability by a factor of 10 raised the tota 1 release probability by less than $0.1 \%$. This is well within the overall accuracy of the analysis. 
Side Impact Fails Seal with Closure Error $(x 111)$

It is assumed that a seal with a closure error would fail from impact twice as frequently as a normal seal. The probability that the seal will have a closure error that affects the impact failure threshold is taken to be the same as the probability of an improperly installed seal (event X118). That value is $9.7 \times 10^{-4}$. The probability of this event was then estimated to be $1.2 \times 10^{-8}$.

\section{End Impact Fails Seal with Closure Error (X112)}

The probability of a seal with a closure error failing from impact was assigned a probability of $3.0 \times 10^{-4}$ (see event $\times 113$ ). The probability of a closure error affecting the seal failure threshold was taken to be $9.7 \times 10^{-4}$ (see event $\times 111$ ). Thus, the probability of event $\times 112$ was estimated to be $2.9 \times 10^{-7}$.

\section{End Impact Fails Defective Seal (X113)}

It is assumed that a defective seal would fail from end impact twice as frequently as a normal seal, giving a probability of $3.0 \times 10^{-4}$ (see event X131). The probability of a defective seal that affects the impact failure threshold is taken to be $3.0 \times 10^{-3}$ (see event $\times 110$ ). Therefore, a value of $9.0 \times 10^{-7}$ failures per rail car accident was then used for this event. (a) End Impact Causes LOC from Seal and Fuel Does Not Fail (X114)

An end impact which causes a loss of coolant was determined to have a probability of $1.5 \times 10^{-4}$ in event $\times 131$. A value of 0.1 was used for the probability of restoring cavity coolant (see event $\times 69$ ). This event was therefore given a probability of $1.5 \times 10^{-5}$.

Fire Duration and Temperature Sufficient to Fail Closure Seal (X115)

For purposes of this analysis, it is assumed that the seal will fail if the temperature exceeds $500^{\circ} \mathrm{C}$ for longer than one hour. The fire must be

(a) An analysis was performed to determine the sensitivity of the total release probability to the probability value used for this event. It was found that increasing this event probability by a factor of 10 raised the total release probability by less than $0.1 \%$. This is well within the overall accuracy of the analysis. 
greater than $2 \mathrm{hrs}$ in length to exceed $500^{\circ} \mathrm{C}$ at the seal. This is estimated based on the thermal analysis in Appendix D. In Figure 5.2, the probability that a rail accident fire duration affecting the cask will exceed $2 \mathrm{hrs}$ is given as $1.0 \times 10^{-2}$. This value was used as the probability that a train fire will fail the closure seal.

Side Impact Causes LOC from Seal and Fuel Does Not Fail (X116)

A side impact causing a loss of coolant was determined in event $\times 132$ to have a probability of $5.9 \times 10^{-6}$ per rail car accident. A value of 0.1 was used for the estimated frequency of restoring the coolant (see event X69). Therefore, a probability of $5.9 \times 10^{-7}$ was assigned to this event. Loss of Coolant from Seal Sufficient to Cause Fuel Failure (X117)

A probability of 1.0 was used for this event (see event $\times 66$ ). Seal Not Installed Properly $(\times 118)$

The survey of packaging errors showed no occurrences of incorrectly installed closure seals. A frequency rate of $9.7 \times 10^{-4}$ per cask at a $50 \%$ confidence level was used for this event. Improperly Installed Seal Causes LOC (X119)

Event $\times 118$ gives the failure rate for an improperly installed seal based on data from the shipping survey summarized in Section 7 . The survey results did not indicate that loss of coolant occurred due to handling errors. It was conservatively assumed that $1 \%$ of the improperly installed closure seals would result in significant leakage. The probability for this event was then set at $1.0 \times 10^{-2}$ per cask shipment. (a)

(a) An analysis was performed to determine the sensitivity of the total release probability to the probability value used for this event. It was found that increasing this event probability by a factor of 10 raised the total release probability by less than $0.1 \%$. This is well within the overall accuracy of the analysis. 
Fuel Does Not Fail When Improperly Installed Seal Causes LOC (X120)

The probability of fuel failure when an improperly installed seal causes loss of cavity coolant is $3.0 \times 10^{-3}$ (see event $\times 121$ ). The probability that fuel does not fail is one minus the probability of failure. Therefore, this event was given a conservative value of 1.0 .

Fuel Fails When Improperly Installed Seal Causes LOC (X121)

A probability of $3.0 \times 10^{-3}$ was used for this event (see event $\times 78$ ). Crushing Force Causes LOC from Seal (X122)

A probability of zero was used for this event (see event $\mathrm{X87}$ ). $(X 123)$ to $(X 126)$ Not Used Defective Seal Installed (X127)

The probability of installing a defective seal was estimated to be the same as the human error failure rate for items contained in a checklist given in Reference 5. The error rate for this event was estimated to be $3 \times 10^{-3}$ per shipment.

Defective Sea 1 Causes LOC (X128)

This event was assigned a probability of $1.0 \times 10^{-2}$ per cask shipment (see event $\mathrm{X} 119$ ).

Fuel Fails When Defective Seal Causes LOC (X129)

This event was assigned a probability of $3.0 \times 10^{-3}$ failures per cask shipment (see event $\mathrm{X78}$ ).

Fuel Does Not Fail When Defective Seal Causes LOC (X130)

This event was given a value of 1.0 (see event $\mathrm{X} 120$ ). End Impact Fails Normal Seal (X131)

An impact failure of the cask seal was estimated (see Section 6.1) to have a failure threshold velocity of $80 \mathrm{~km} / \mathrm{hr}$ for an end impact. Based on data from Sandia for a rail cask transport system summarized in Figure 5.4, the probability that the cask will experience a velocity change of $80 \mathrm{~km} / \mathrm{hr}$ or greater was estimated to be $1.5 \times 10^{-4}$ per rail car accident. 
Side Impact Fails Normal Seal (X132)

Failure thresholds summarized in Section 6 show that a velocity change of $72 \mathrm{~km} / \mathrm{hr}$ would be required to cause failure of the cask seal in a side impact onto a flat surface. From Reference 1, the probability that the cask will be accelerated perpendicular to its axis in a side-on impact is $2.1 \times 10^{-2}$. The probability of a velocity change of $72 \mathrm{~km} / \mathrm{hr}$ or greater in a collision accident is given in Figure 5.4 as $2.8 \times 10^{-4}$. The probability of this event is then estimated to be $5.9 \times 10^{-6}$ per rail car accident.

Thermal Forces Fail Seal and Fuel (X133)

From the discussion for event $\times 115$, it was shown that the fire must exceed 2 hrs to damage the seal. The fuel is affected if the fire exceeds one-half $h r$. Therefore, to fail both the seal and the fuel, a fire must exceed 2 hrs. Thus, the probability for this event was set at $1.0 \times 10^{-2}$.

$(\times 134)$ to $(\times 149)$ Not Used

Immersion Forces Fail Cask Body and Fuel (X150)

A probability of zero was used for this event (see event $\times 50$ ).

Crush Forces Fail Cask Body and Fuel (X151)

A probability of zero was used for this event (see event $\times 51$ ).

Puncture Probe Fails Cask Body (X152)

Data on puncture of large packages gives rates for puncture situations per train accident on the basis of equivalent steel thickness of the package. The equivalent steel thickness of the reference cask was determined to be about $15.24 \mathrm{~cm}$ ( $6 \mathrm{in.}$ ) of mild steel. Table 5.2 shows that the frequency of puncture that could fail the cask cavity wall would be $5.8 \times 10^{-17}$ failures per $\mathrm{km}$. Combined with the rail accident rate of $6.2 \times 10^{-6} \mathrm{car} / \mathrm{km}$ gives a value for this event of $9.4 \times 10^{-12}$.

Side Impact Fails Normal Cask Body (X153)

Information summarized in Section 6.1 shows that a velocity change of $70 \mathrm{~km} / \mathrm{hr}$ is required to fail the cask in a side-on impact. The probability that the cask will be impacted perpendicular to its axis is $2.1 \times 10^{-2}$. The 
probability of a velocity change of $70 \mathrm{~km} / \mathrm{hr}$ or greater in a collision accident is given in Figure 5.4 as $4.0 \times 10^{-4}$. The total probability estimated for this event was then $8.4 \times 10^{-6}$ per rail car accident.

Side Impact Fails Fuel and Defective Cask Body (X154)

A side impact failure of both the fuel and a defective cask wall was estimated to be twice as probable as a normal wall (event $\mathrm{X153)}$ ). A value of $1.7 \times 10^{-5}$ per rail car accident was used for the event. (a)

End Impact Fails Normal Cask Body (X155)

Information presented in Section 6.1 shows that a velocity change of $150 \mathrm{~km} / \mathrm{hr}$ is required to fail the cask sufficiently for a large breach to occur. The probability of a velocity change of $150 \mathrm{~km} / \mathrm{hr}$ or greater in a collision accident was estimated from Figure 5.4 to be $1.0 \times 10^{-5}$.

End Impact Fails Fuel and Defective Cask (X156)

An end impact which fails both the fuel and a defective cask was estimated to be two times as probable as a failure of a normal wall. A value of $2.0 \times 10^{-5}$ for the large breach was used for this event. (a)

Side Impact Fails Normal Cask Body and Fuel (X157)

A velocity change of $72 \mathrm{~km} / \mathrm{hr}$ is required to fail the wall and $50 \mathrm{~km} / \mathrm{hr}$ to fail the fuel. The velocity change required to fail both the wall and fuel would be $72 \mathrm{~km} / \mathrm{hr}$. From event $\times 153$, the probability of failure for a $72 \mathrm{~km} / \mathrm{hr}$ velocity change were shown to be $2.8 \times 10^{-4}$. This value was used for event X157.

End Impact Fails Normal Cask Body and Fuel (X158)

It is assumed for this study that a velocity change of $150 \mathrm{~km} / \mathrm{hr}$ is required to cause a large breach of the cask which would result in a substantial opening of the cask cavity. The fuel is assumed to fail at $70 \mathrm{~km} / \mathrm{hr}$. A velocity

(a) An analysis was performed to determine the sensitivity of the total release probability to the probability value used for this event. It was found that increasing this event probability by a factor of 10 raised the total release probability by less than $0.1 \%$. This is well within the overall accuracy of the analysis. 
change of $150 \mathrm{~km} / \mathrm{hr}$ would thus be required to fail both the wall and the fuel. The probability for this event was then assumed to be $1.0 \times 10^{-5}$ for a large breach to occur (see event $\times 155$ ).

Puncture Probe Fails Cask and Fuel (X159)

A puncture failure of the cask was determined in event $\times 152$ to have a probability of $9.4 \times 10^{-12}$. It is assumed that this would also fail the fuel; thus, this component was assigned a value of $9.4 \times 10^{-12}$.

Puncture Probe Fails Cask Body Causing LOC and Fuel Does Not Fail (X160)

A puncture failure of the cask wall resulting in a loss of coolant was determined in event $\times 152$ to have a probability of $9.4 \times 10^{-12}$. From event $\times 69$, the probability of restoring the coolant following an accident was estimated to be 0.1 . Therefore, a value of $9.4 \times 10^{-3}$ was used for this event. (a)

Side Impact Causes LOC from Cask Body and Fuel Does Not Fail (X161)

A side impact which causes a loss of coolant was determined to have a probability of $8.4 \times 10^{-6}$ from event $\times 153$. A probability of 0.1 was used for the estimated frequency of restoring the coolant (see event X69). This event was then given a value of $8.4 \times 10^{-7}$.

End Impact Causes LOC from Cask Body and Fuel Does Not Fail (X162)

The probability of loss of coolant from the cask wall caused by an end impact was estimated to be $1.5 \times 10^{-4}$ based on a velocity change of $80 \mathrm{~km} / \mathrm{hr}$. A value of 0.1 was used for the probability of restoring the coolant (see event $\times 69)$. This event was then assigned a probability of $1.5 \times 10^{-5}$ (a) Side Impact Fails Defective Cask Body (X163)

A side impact failure of a defective cask wall was estimated to be twice as probable as a normal wall. Thus, a value of $1.7 \times 10^{-5}$ was used for this event (twice that of event $\times 153$ ). (a)

(a) An analysis was performed to determine the sensitivity of the total release probability to the probability value used for this event. It was found that increasing this event probability by a factor of 10 raised the total release probability by 1 ess than $0.1 \%$. This is well within the overall accuracy of the analysis. 
End Impact Fails Defective Cask Body (X164)

An end impact failure of a defective cask wall was estimated to be twice as frequent as a normal wall. Thus, a value of $2.0 \times 10^{-5}$ (twice that of event $\times 155$ ) was used for this event. (a)

Defective Weld Causes LOC During Normal Transport (X165)

No data are available for this event. A weld defective enough to cause leakage of cask coolant should be detected during inspections to meet quality requirements. It is remotely possible that such a weld could be missed before the cask would be put into service and fail during transport, resulting in a loss of coolant. For that reason, a low probability of occurrence of $10^{-4}$ per shipment was used for this event. (a)

Loss of Coolant from Cask Body Causes Fuel Failure (X166)

A probability of 1.0 was assigned to this event (see event $\times 66$ ).

Fuel Does Not Fail When Defective Weld Causes LOC (X167)

This event was given a value of 1.0 (see event $\times 120$ ).

Fuel Fails When Defective Weld Causes LOC (X168)

This event was assigned a probability of $3.0 \times 10^{-3}$ failures per cask shipment (see event $x 78$ ).

Weld to Cask Bottom Defective During Transport (X169)

Data on welds for reactor containments for Reference 5 give a value of $1 \times 10^{-7}$ serious leaks per hour. Assuming one day of operation per shipment, the welds would have a probability of failure of $2.4 \times 10^{-6}$ per shipment.

End Impact Fails Normal Cask Body and LOC Occurs (X170)

Failure threshold data summarized in Section 6.1 show that a velocity change of $80 \mathrm{~km} / \mathrm{hr}$ in an end impact would be required to fail the cask

(a) An analysis was performed to determine the sensitivity of the total release probability to the probability value used for this event. It was found that increasing this event probability by a factor of 10 raised the total release probability by less than $0.1 \%$. This is well within the overall accuracy of the analysis. 
sufficiently for leakage to occur. The probability of a velocity change of $80 \mathrm{~km} / \mathrm{hr}$ or greater in a collision accident is given in Figure 5.4 as $1.5 \times 10^{-4}$. End Impact Fails Defective Cask Body and LOC Occurs (X171)

An end impact failure of a defective cask wall was estimated to be twice as frequent as a normal wall. This gives a value of $3.0 \times 10^{-4}$ (twice that of event $\times 170)$. The probability that the cask wall will have a defect that weakens it structurally is taken to be the same as the probability of a manufacturing defect. A value of $3.0 \times 10^{-3}$ is used (see event $\times 65$ ). Therefore, the probability of this event was estimated to be $9.0 \times 10^{-7}$ per rail car accident. (a) (X172) to (X199) Not Used Immersion Force Fails PR Valve and Fuel (X200)

A probability of zero was used for this event (see event $\times 50$ ). Crushing Force Fails PR Valve and Fuel (X201)

A probability of zero was used for this event (see event $\times 51$ ). Puncture Probe Strikes PR Valve and Fuel (X202)

The probability that a puncture probe will strike the pressure relief valve is $1.8 \times 10^{-3}$ (event $\times 220$ ) and to strike the fuel, 0.63 (see event $\times 10$ ). The probability of this event was then estimated to be $1.1 \times 10^{-3}$. Puncture Probe Fails PR Valve and Fuel (X203)

The probability that a puncture probe fails the pressure relief device is $4.9 \times 10^{-4}$ (event $\times 219$ ) and the fuel $9.4 \times 10^{-12}$ (event $\times 152$ ). The probability of this event was then estimated to be $9.4 \times 10^{-12}$ per accident.

Side Impact Fails Normal PR Valve and Fuel (X204)

A velocity change of $72 \mathrm{~km} / \mathrm{hr}$ is required to fail the relief valve and $50 \mathrm{~km} / \mathrm{hr}$ to fail the fuel in the side impact case. The velocity change required

(a) An analysis was performed to determine the sensitivity of the total release probability to the probability value used for this event. It was found that increasing this event probability by a factor of 10 raised the total release probability by less than $0.1 \%$. This is well within the overall accuracy of the analysis. 
End Impact Fails PR Valve and Fuel When Valve Damaged During Handling (X211)

It is assumed that the fuel and a damaged valve would fail twice as frequently as a normal valve. A value of $3.0 \times 10^{-4}$ (twice that of event $\times 205$ ) was used for this event. (a)

Loss of Coolant from PR Valve Sufficient to Fail Fuel (X212)

A probability of 1.0 was used for this event (see event $\times 66$ ). Defective PR Valve Installed (X213)

The survey showed that one cask was received with a defective pressure relief device which required replacement out of a total of about 3,580 shipments. It was learned that no shipments covered in the survey involved overpressurization of the cask wherein a pressure relief device would be actuated. It was then conservatively assumed that the defective pressure relief valve would have resulted in a release of radioactivity; thus, the probability of this event was estimated to be $2.8 \times 10^{-4}$ per shipment.

Pressure Rel ief Valve Not Installed Properly (X214)

No cases of improper installation of a pressure relief valve were found in the survey. Based on a $50 \%$ confidence limit, a value of $1.9 \times 10^{-4}$ was estimated for this event.

Pressure Relief Valve Damaged During Handling (X215)

No cases of damage to the pressure relief valve during handling were found in the survey. Based on a $50 \%$ confidence limit, a value of $1.9 \times 10^{-4}$ was estimated for this event.

Crushing Forces Cause LOC from PR Valve (X216)

A probability of zero was used for this event (see event $\times 87$ ).

(a) An analysis was performed to determine the sensitivity of the total release probability to the probability value used for this event. It was found that increasing this event probability by a factor of 10 raised the total release probability by less than $0.1 \%$. This is well within the overall accuracy of the analysis. 


\section{Side Impact Fails Normal PR Valve (X217)}

Threshold side impact velocity changes to fail the pressure relief valve were assumed to be the same as that required to fail the cask seal (event X132). Based on a velocity change of $72 \mathrm{~km} / \mathrm{hr}$ and a side impact probability of $2.1 \times 10^{-2}$, the probability of this event was set at $5.9 \times 10^{-6}$ per rail car accident.

End Impact Fails Normal PR Valve (X218)

The pressure relief valve is located in the finned valve box and is wellprotected from end-impact forces. It is assumed that only impact which would cause a large breach of the cask cavity could fail the pressure relief valve. Therefore, this event was not analyzed and a probability of zero was used. Puncture Probe Fails PR Valve (X219)

The equivalent steel thickness of the pressure relief valve and valve box was estimated to be about $2.5 \mathrm{~cm}$. Based on data using the equivalent steel thickness and the proportional area of the valve to the cask as $1 \%$, it was estimated that the frequency of puncture that would fail the pressure relief valve would be approximately $4.9 \times 10^{-3}$ per accident.

Puncture Probe Strikes PR Valve (X220)

Puncture data summarized in Section 5.6 give the frequency of puncture for large packages, given that a puncture situation exists. The probability that a puncture probe strikes the pressure relief valve given that a puncture probe strikes the cask is based on the projected area of the valve compared to the projected area of the cask. It was estimated that the probability of a puncture probe striking the pressure relief device would be $1.8 \times 10^{-3}$. Fire Duration and Temperature Sufficient to Cause LOC from PR Valve (X221)

The pressure relief valve was assumed to relieve pressure at 23.8 atmospheres ( $350 \mathrm{psig})$. The thermal analysis summarized in Section 6.2 showed that a 50-minute or greater duration fire at $1,010^{\circ} \mathrm{C}$ would result in a pressure exceeding the valve relief pressure and a loss of cavity coolant. From Figure 5.1 , the probability of a fire which could affect the cask exceeding 50 minutes is about 0.055 . The probability of this event was then taken to be $5.5 \times 10^{-2}$ per rail car accident. 
$(\times 222)$ and $(\times 223)$ Not Used

Fuel Does Not Fail When Defective PR Valve Causes LOC (X224)

The probability of fuel failure when a defective pressure relief valve causes loss of cavity coolant is $3.0 \times 10^{-3}$ (see event $\times 226$ ). The probability that the fuel does not fail is one minus the probability of failure. Therefore, this event was given a conservative value of 1.0 .

Fuel Fails When Improperly Installed PR Valve Causes LOC (X225)

A probability of $3.0 \times 10^{-3}$ failure per cask shipment was used for this event (see event $\times 78$ ).

Puncture Probe Causes LOC from PR Valve and Fuel Does Not Fail (X227)

The probability that a puncture probe fails the pressure relief valve is assumed to be $4.9 \times 10^{-4}$ punctures per accident (see event $\times 219$ ). The probability of restoring the coolant is assumed to be 0.1 (see event $\times 69$ ). Therefore, a value of $4.9 \times 10^{-5}$ was used for this event.

Fire Causes LOC from PR Valve and Fuel Does Not Fail (X228)

The probability that a fire accident causes a loss of coolant from the pressure relief valve is assumed to be $5.5 \times 10^{-2}$ (see event $\times 221$ ). The probability of restoring the coolant is assumed to be 0.1 (see event X69). Therefore, the value used for this event was $5.5 \times 10^{-3}$.

Side Impact Causes LOC from PR Valve and Fuel Does Not Fail (X229)

A side impact causing failure of the pressure relief valve was determined in event $\times 217$ to have a probability of $5.9 \times 10^{-6}$. This would result in a loss of cavity coolant. A value of 0.1 was used for the estimated frequency of restoring the coolant (see event $\times 69$ ). Therefore, a probability or $5.9 \times 10^{-7}$ was assigned to this event.

Side Impact Fails PR Valve Damaged During Handling (X230)

It is assumed that a damaged pressure relief valve would fail from a side impact twice as frequently as a normal relief valve. This gives a value of $1.2 \times 10^{-5}$ per rail car accident (twice that of event $\times 217$ ). The 
probability that a valve will be damaged sufficiently to affect its impact threshold is taken to be the same as the probability of damage during handling. A value of $1.9 \times 10^{-4}$ is used (event $\times 215$ ). Therefore, a value of $2.3 \times 10^{-9}$ was used for this event. (a)

Side Impact Fails Improperly Installed PR Valve (X231)

It is assumed that an improperly installed pressure relief valve would fail from a side impact twice as frequently as a normal relief valve. This gives a value of $1.2 \times 10^{-5}$ collisions per collision accident (twice that of event $\times 217)$. The probability that an improperly installed device will affect the impact failure threshold is $1.9 \times 10^{-4}$ (event $\times 214$ ). Thus, a probability of $2.3 \times 10^{-9}$ per rail car accident was used for this event. (a)

Side Impact Fails Defective PR Valve (X232)

It is assumed that a defective pressure relief valve would fail from a side impact twice as frequently as a normal relief valve. This gives a value of $1.2 \times 10^{-5}$ collisions per collision accident (twice that of event $\times 217$ ). The probability that a defective valve will affect the impact failure threshold is $2.8 \times 10^{-4}$ (event $\times 213$ ). Therefore, the probability of this event was estimated to be $3.4 \times 10^{-9}$.

$\underline{(x 233) \text { Not Used }}$

Fuel Does Not Fail When Improperly Installed PR Valve Causes LOC (X234)

A probability of 1.0 was used for this event (see event $\times 224$ ). Improperly Installed PR Valve Causes LOC (X235)

Event $\times 214$ gives the failure rate for an improperly installed pressure relief valve based on data from the shipping survey summarized in Section 7. The survey results did not indicate that loss of coolant occurred due to any handling errors. It is conservatively assumed that $1 \%$ of the improperly

(a) An analysis was performed to determine the sensitivity of the total release probability to the probability value used for this event. It was found that increasing this event probability by a factor of 10 raised the total release probability by less than $0.1 \%$. This is well within the overall accuracy of the analysis. 
installed relief valves would result in significant leakage. The rate for this event was then set at $1.0 \times 10^{-2}$ per shipment. (a)

Defective PR Device Causes LOC (X236)

A probability of $1.0 \times 10^{-2}$ was used for this event (see event $\times 235$ ). (a) (X237) Not Used

Damaged PR Valve Causes LOC (X238)

A probability of $1.0 \times 10^{-2}$ was used for this event (see event $\times 235$ ). (a) Fuel Fails when Damaged PR Valve Causes LOC (X239)

A probability of $3.0 \times 10^{-3}$ failures per cask shipment was used for this event (see event $\mathrm{X78}$ ).

Fuel Does Not Fail When Damaged PR Valve Causes LOC (X240)

A probability of 1.0 was used for this event (see event $\mathrm{X224}$ ).

Impact Fails Neutron Shield Causing LOC from PR Valve and Fuel Does Not Fail (X241)

The probability of an impact failing the neutron shield is estimated to be $5.5 \times 10^{-4}$ based on impact data shown in Figure 5.4 for a velocity change of $40 \mathrm{kph}$ required to damage the cask tiedowns and allow the cask to fall off the vehicle. A value of 0.1 was used for the probability of restoring the cavity coolant (see event $\times 69$ ). This event was thus given a value of $5.5 \times 10^{-5}$. Impact Fails Neutron Shield Causing LOC from PR Valve (X242)

The probability that an impact can fail the neutron shield is $5.5 \times 10^{-4}$ (see event $\times 241$ ). It is assumed that the impact will also cause loss of mechanical cooling; thus, a loss of coolant through the pressure relief valve will occur after about 30 hours. Since it is not known if any action can be taken, the probability of restoring coolant is given a value of 0.5 . This event then has a value of $2.7 \times 10^{-4}$.

(a) An analysis was performed to determine the sensitivity of the total release probability to the probability value used for this event. It was found that increasing this event probability by a factor of 10 raised the total release probability by less than $0.1 \%$. This is well within the overall accuracy of the analysis. 
Fire Fails Neutron Shield Causing LOC from PR Valve and Fuel Does Not Fail (X243)

Based on thermal calculations for cask safety analysis, it is assumed that a fire longer than 30 minutes will cause loss of the neutron shield water. This gives a value of $5.0 \times 10^{-2}$ for the probability of a 30 -minute fire, which could affect the rail cask. Combining this with the probability of restoring the c001ant (see event $\times 69$ ) is given a probability of $5 \times 10^{-3}$.

Fire Fails Neutron Shield Causing Loss of Coolant from the PR Valve (X244)

A probability of $5.0 \times 10^{-2}$ was used for this event (see event $\times 243$ ). (X245) Not Used

Crushing Force Fails Neutron Shield Causing LOC from PR Valve and Fuel Does Not Fail (X246)

The probability of a crushing accident failing the neutron shield is $2 \times 10^{-3}$ per rail car accident. A value of 0.1 was used for the probability of restoring cavity coolant (see event X69). The probability of this event was then estimated to be $2.0 \times 10^{-4}$.

Crushing Force Fails Neutron Shield Causing LOC from PR Valve (X247)

The probability that a crushing force can fail the neutron shield is $2.0 \times 10^{-3}$. It is conservatively assumed that the crushing accident will also fail the mechanical cooling system; therefore, a loss of coolant through the pressure relief valve will occur after about 30 hours. Since it is not known if any action can be taken to prevent the loss of coolant, the probability of restoring coolant is given a value of 0.5 . Thus, this event was given a value of $1.0 \times 10^{-3}$.

Fire Fails PR Valve and Fuel (X248)

The pressure relief valve can withstand a temperature of $400^{\circ} \mathrm{C}\left(750^{\circ} \mathrm{F}\right)$. It is conservatively estimated that a fire of 2 hours would cause failure of the pressure relief valve based on data in Appendix $D$. This gives a probability of $1 \times 10^{-2}$ for a fire which could affect the cask lasting 2 hours. In a 2-hour fire the coolant is lost in about 2 hours and the fuel would start to 
fail after about 3.5 hours. If it is assumed that the probability of preventing loss of coolant is 0.5 the probability of this event is then $5 \times 10^{-3}$.

Immersion Force Fails Fill Valve and Fuel (X250)

A probability of zero was used for this event (see event $\times 50$ ).

Crushing Force Fails Fill Valve and Fuel (X251)

A probability of zero was used for this event (see event $\times 51$ ).

Puncture Probe Strikes Fill Valve and Fuel (X252)

The probability that a puncture probe will strike the drain valve is $1.8 \times 10^{-3}$ (event $\times 277$ ) and to strike the fuel 0.63 (event $\times 10$ ). The probability of this event was then estimated to be $1.1 \times 10^{-3}$.

Puncture Probe Fails Fill Valve and Fuel (X253)

The probability that a puncture probe fails the drain valve is $4.9 \times 10^{-4}$ (event $\times 283$ ) and the fuel $9.4 \times 10^{-12}$ (event $\times 152$ ). The probability of this event was then estimated to be $9.4 \times 10^{-12}$ per accident.

Side Impact Fails Normal Fill Valve and Fuel (X254)

A velocity change of $72 \mathrm{~km} / \mathrm{hr}$ is required to fail the drain valve and $50 \mathrm{~km} / \mathrm{hr}$ to fail the fuel in the side impact case. The velocity change required to fail both the drain valve and fuel would be $72 \mathrm{~km} / \mathrm{hr}$. From event $\times 280$, the probability of failure is $5.9 \times 10^{-6}$ per collision accident for that velocity change.

Side Impact Fails Fill Valve and Fuel When Valve Defective (X255)

A side-impact failure of the fuel and a defective drain valve was estimated to be twice as probable as a normal drain valve. A value of $1.2 \times 10^{-5}$ (twice that of event $\mathrm{X254}$ ) was used for this event. (a)

(a) An analysis was performed to determine the sensitivity of the total release probability to the probability value used for this event. It was found that increasing this event probability by a factor of 10 raised the total release probability by less than $0.1 \%$. This is well within the overall accuracy of the analysis. 
Side Impact Fails Fill Valve and Fuel When Valve Damaged During Handling (X256)

A side impact failure of both the fuel and a damaged fill valve was estimated to be twice the probability of failing a normal fill valve. A value of $1.2 \times 10^{-5}$ (twice that of event $\times 254$ ) was used for this event. (a)

Side Impact Fails Fill Valve and Fuel When Valve Not Installed Properly (X257)

A side impact failure of the fuel and an improperly installed fill valve was estimated to be twice as frequent as a normal valve. A value of $1.2 \times 10^{-5}$ (twice that of event $\times 254$ ) was used for this event. (a)

Crushing Force Causes LOC from Fill Valve (X258)

A probability of zero was used for this event (see event $\times 87$ ).

End Impact Fails Normal Fill Valve and Fuel (X259)

This event was given a probability of zero (see event $\times 281$ ). Loss of Coolant from Fill Valve Sufficient to Fail Fuel (X260)

No cases of improper installation of fill valves were found in the survey. Based on a $50 \%$ confidence limit, a value of $1.9 \times 10^{-4}$ was then estimated for this event.

Fuel Does Not Fail When Defective Fill Valve Causes LOC (X262)

The probability of fuel failure when a defective fill valve causes loss of cavity coolant is $3.0 \times 10^{-3}$ (see event $\times 264$ ). The probability that fuel does not fail is one minus the probability of failure. Therefore, this event was given a conservative value of 1.0 .

Fuel Fails when Improperly Installed Fill Valve Causes LOC (X263)

A probability of $3.0 \times 10^{-3}$ failures per cask shipment was used for this event (see event $\times 78$ ).

(a) An analysis was performed to determine the sensitivity of the total release probability to the probability value used for this event. It was found that increasing this event probability by a factor of 10 raised the total release probability by less than $0.1 \%$. This is well within the overall accuracy of the analysis. 
Fuel Fails When Defective Fill Valve Causes LOC (X264)

A probability of $3.0 \times 10^{-3}$ failure per cask shipment was used for this event (see event $\times 78$ ).

Puncture Probe Causes LOC from Fill Valve and Fuel Does Not Fail (X265)

The probability that a puncture probe fails the drain valve is assumed to be $4.9 \times 10^{-4}$ per accident (see event $\times 283$ ). The probability of restoring the coolant is assumed to be 0.1 (see event $\times 69$ ). Therefore, a value of $4.9 \times 10^{-5}$ was used for this event.

Fire Causes LOC from Fill Valve and Fuel Does Not Fail (X266)

The probability that a fire accident fails the fill valve is assumed to be $1.0 \times 10^{-2}$ (see event $\times 279$ ). The probability of restoring the coolant is assumed to be 0.1 (see event $\times 69$ ). Therefore, the value used for this event was $1.0 \times 10^{-3}$.

Side Impact Causes LOC from Fill Valve and Fuel Does Not Fail (X267)

A side impact causing failure of the drain valve was determined in event $\times 280$ to have a probability of $5.9 \times 10^{-6}$. This would result in a loss of cavity coolant. A value of 0.1 was used for the estimated frequency of restoring the coolant (see event $\times 69$ ). Therefore, a probability of $5.9 \times 10^{-7}$ was assigned to this event.

Side Impact Fails Fill Valve Damaged During Handling (X268)

It is assumed that a damaged drain valve would fail from a side impact twice as frequently as a normal drain valve. A value of $1.2 \times 10^{-5}$ per rail car accident (twice that of event $\times 280$ ) is used. The probability that a damaged drain valve will be weakened so that the impact failure threshold is reduced is taken to be the same as a damaged valve (event $\times 275$ ). A value of $1.9 \times 10^{-4}$ is used. Therefore, the probability of this event was estimated to be $2.2 \times 10^{-9}$ per rail car accident. (a)

(a) An analysis was performed to determine the sensitivity of the total release probability to the probability value used for this event. It was found that increasing this event probability by a factor of 10 raised the total release probability by less than $0.1 \%$. This is we 11 within the overall accuracy of the analysis. 
Side Impact Fails Improperly Installed Fill Valve (X269)

It is assumed that an improperly installed drain valve would fail from a side impact twice as frequently as a normal fill valve. This value of $1.2 \times 10^{-5}$ per rail car accident (twice that of event $\times 280$ ) is used. The probability that an improperly installed fill valve will weaken the impact failure threshold strength is taken to be $1.9 \times 10^{-4}$ (event $\times 261$ ). Therefore, the probability of this event was taken to be $2.2 \times 10^{-9}$. (a)

Side Impact Fails Defective Fill Valve (X270)

It is assumed that a defective fill valve would fail from a side impact twice as frequently as a normal fill valve. Thus, a value of $1.2 \times 10^{-5}$ per collision accident (twice that of event $\times 280$ ) is used. The probability that a defective valve will affect the impact failure threshold is estimated to be $5.5 \times 10^{-4}$ (event $\times 273$ ). The probability of this event was then estimated to be $6.6 \times 10^{-9}$ per rail car accident. (a)

Fuel Does Not Fail When Improperly Installed Fill Valve Causes LOC (X271)

A probability of 1.0 was used for this event (see event $\times 262$ ). Improperly Installed Fill Valve Causes LOC (X272)

Event $X 261$ gives the failure rate for an improperly installed drain valve based on data from the shipping survey summarized in Section 7 . The survey results did not indicate that loss of coolant occurred due to any handing errors. It is conservatively assumed that $1 \%$ of the improperly installed fill valves would result in significant leakage. The rate for this event was then set at $1.0 \times 10^{-2}$ per shipment. (a)

(a) An analysis was performed to determine the sensitivity of the total release probability to the probability value used for this event. It was found that increasing this event probability by a factor of 10 raised the total release probability by less than $0.1 \%$. This is well within the overall accuracy of the analysis. 
Defective Fill Valve Installed (X273)

Results of the survey showed that two cask shipments out of 3,580 rail car shipments had been installed with a defective fill valve. The probability of this event was then estimated to be $5.5 \times 10^{-4}$ per shipment.

Fill Valve Leaks from Wear Causing LOC (X274)

Information provided on this event in the survey showed that $10 \mathrm{fill}$ valves required replacement due to wear in all of the rail car shipments. This gives a frequency of occurrence of about $2.8 \times 10^{-3}$ per cask shipment. Combining this rate with the probability of a loss of coolant due to a packaging or handling error (see event X272) gives a probability for this event of $2.8 \times 10^{-5}$. (a)

\section{Fill Valve Damaged During Handling (X275)}

No cases of damage to the fill valve during handling were found in the survey. Based on a $50 \%$ confidence 1 imit, a value of $1.9 \times 10^{-4}$ was estimated for this event.

Fill Valve Not Closed Causing LOC (X276)

No incidence of casks received with fill valves not closed were reported in the survey. At a $50 \%$ confidence level based on the sample size involved, it would be expected that this packaging error would occur at a rate of $1.9 \times 10^{-4}$ per cask shipment. Combining this rate with the probability of a loss of coolant occurring due to a packaging error (see event $\times 272$ ) gives a probability for this event of $1.9 \times 10^{-6}$ per shipment. (a)

Puncture Probe Strikes Fill Valve (X277)

Puncture data summarized in Section 5.6 gives the frequency of puncture for large packages given that a puncture situation exists. The probability that a puncture probe strikes the fill valve, given that the puncture probe strikes the cask, is based on the projected area of the valve compared to the

(a) An analysis was performed to determine the sensitivity of the total release probability to the probability value used for this event. It was found that increasing this event probability by a factor of 10 raised the total release probability by less than $0.01 \%$. This is well within the overall accuracy of the analysis. 
projected area of the cask. It was estimated that the probability of a puncture probe striking the fill valve would be $3 \times 10^{-4}$.

Defective Fill Valve Causes LOC (X278)

A probability of $1.0 \times 10^{-2}$ was used for this event (see event $\times 272$ ). (a) Fire Temperature and Duration Sufficient to Fail Fill Valve (X279)

The fill valve can withstand temperatures of $400^{\circ} \mathrm{C}\left(750^{\circ} \mathrm{F}\right)$. It is conservatively estimated that a 2-hour fire would cause failure of the fill valve. From Section 5, it is shown that a 2-hour fire which could expel the cask has a probability of $1.0 \times 10^{-2}$, the value used for this event.

Side Impact Fails Normal Fill Valve (X280)

A side-on collision is required for the drain valve to experience impact forces. Threshold side-impact velocity changes for fill valve were conservatively assumed to be the same as that required to fail the cask seal. It is also assumed that the impact must occur at the location of the drain valve in the cask flange for failure to occur. A value of 0.25 is assumed for the probability of impacting the drain valve. Based on a velocity change of $72 \mathrm{~km} / \mathrm{hr}$ and a side-impact probability of $2.1 \times 10^{-2}$ (see event $\times 85$ ), the probability of this event was then set at $5.9 \times 10^{-6}$ per rail car accident.

End Impact Fails Normal Fill Valve (X281)

The fill valves are located in finned valve boxes and are very well protected from end-impact forces. It is assumed that only impacts which would cause a large breach of the cask cavity could fail the drain valve. Therefore, this event was not analyzed, and a probability of zero was used.

Damaged Fill Valve Causes LOC (X282)

A probability of $1.0 \times 10^{-2}$ was used for this event (see event $\times 272$ ). (a)

(a) An analysis was performed to determine the sensitivity of the total release probability to the probability value used for this event. It was found that increasing this event probability by a factor of 10 raised the total release probability by less than $0.1 \%$. This is well within the overall accuracy of the analysis. 
The equivalent steel thickness of the fill valve and valve box was estimated to be about $2.5 \mathrm{~cm}$. Based on data in Table 5.2 , it was determined that the frequency of puncture that could fail the drain valve would be approximately $4.9 \times 10^{-4}$ per accident.

Overpressure Fails Fill Valve (X284)

It was conservatively assumed that the fill valve would fail if the pressure exceeds the design pressure of the pressure relief device on the cask. The thermal analysis summarized in Section 6.2 showed that the system would reach $24.1 \mathrm{kPa}$ (gage) (3.50 psig) with a fire exceeding about 1 hour. The probability of the fire exceeding 1 hour, which would affect the cask, was determined to be about 0.02 . Therefore, the occurrence rate for this event was set at $2 \times 10^{-2}$ per fire accident.

Fuel Does Not Fail When Fill Valve Leaks from Wear (X285)

A probability of 1.0 was used for this event (see event X262). Fuel Does Not Fail When Fill Valve Is Not Closed (X286)

A probability of 1.0 was used for this event (see event X262). Fuel Fails When Fill Valve Leaks from Wear Causing LOC (X287)

A probability of $3.0 \times 10^{-3}$ failures per cask shipment was used for this event (see event $X 78$ ).

Fuel Fails When Fill Valve Not Closed Causes LOC (X288)

A probability of $3.0 \times 10^{-3}$ failures per cask shipment was used for this event (see event $X 78$ ).

Fuel Does Not Fail When Damaged Fill Valve Causes LOC (X290)

A probability of 1.0 was used for this event (see event X262). Fire Fails Fill Valve and Fuel (X291)

The probability of the fill valve failing due to fire was determined to be $1.0 \times 10^{-2}$ (see event $\times 279$ ). The fuel will eventually fail if a loss of 
coolant occurs due to failure of the fill valve. Thus the value of this event is set equal to the probability of failure of the valve, $1.0 \times 10^{-2}$. Crushing Force Fails Vent Valve and Fuel (X301)

A probability of zero was used for this event (see event $\times 51$ ). Puncture Probe Strikes Vent Valve and Fuel (X302)

The probability that a puncture probe will strike the vent valve is $1.8 \times 10^{-3}$, and to strike the fuel, 0.63 . The probability of this event was then estimated to be $1.1 \times 10^{-3}$.

Puncture Probe Fails Vent Valve and Fuel (X303)

The probability that a puncture probe fails the vent valve is $4.9 \times 10^{-4}$ (event $\times 333$ ) and the fuel $9.4 \times 10^{-12}$ (event $\times 152$ ). The probability of this event was then estimated to be $9.4 \times 10^{-12}$ per accident.

Side Impact Fails Normal Vent Valve and Fuel (X304)

A velocity change of $72 \mathrm{~km} / \mathrm{hr}$ is required to fail the vent valve and $50 \mathrm{~km} / \mathrm{hr}$ to fail the fuel in the side-impact case. The velocity change required to fail both the vent valve and fuel would be $72 \mathrm{~km} / \mathrm{hr}$. From event $\times 330$, the probability of failure is $5.9 \times 10^{-6}$ per collision accident for that veolocity change.

Side Impact Fails Vent Valve and Fuel When Valve Defective (X305)

A side impact failure of the fuel and a defective vent valve was estimated to be twice as probable as a normal vent valve. A value of $1.2 \times 10^{-5}$ (twice that of event $\times 304$ ) was used for this event. (a)

Side Impact Fails Vent Valve and Fuel When Valve Damaged During Handling (X306)

A side impact failure of both the fuel and a damaged vent valve was estimated to be twice the probability of failing a normal vent valve. A value of $1.2 \times 10^{-5}$ (twice that of event $\times 304$ ) was used for this event. (a)

(a) An analysis was performed to determine the sensitivity of the total release probability to the probability value used for this event. It was found that increasing this event probability by a factor of 10 raised the total release probability by less than $0.01 \%$. This is well within the overall accuracy of the analysis. 
Side Impact Fails Vent Valve and Fuel when Valve Not Installed Properly (X307)

A side-impact failure of the fuel and an improperly installed vent valve was estimated to be twice as frequent as a normal valve. A value of $1.2 \times 10^{-5}$ (twice that of event $\times 304$ ) was used for this event. (a)

Crushing Force Causes LOC from Vent Valve (X308)

A probability of zero was used for this event (see event $\times 87$ ).

End Impact Fails Normal Vent Valve and Fuel (X309)

This event was given a probability of zero (see event $\times 331$ ). Loss of Coolant from Vent Valve Sufficient to Fail Fuel (X310)

A probability of 1.0 was used for this event (see event $\times 66$ ). Vent Valve Not Installed Properly (X311)

No cases of improper installation of vent valves were found in the survey. Based on a $50 \%$ confidence limit, a value of $1.9 \times 10^{-4}$ was then estimated for this event.

Fuel Does Not Fail When Defective Vent Valve Causes LOC (X312)

The probability of fuel failure when a defective vent valve causes loss of cavity coolant is $3.0 \times 10^{-3}$ (see event $\times 314$ ). The probability that fuel does not fail is one minus the probability of failure. Therefore, this event was given a conservative value of 1.0 .

Fuel Fails when Improperly Installed Vent Valve Causes LOC (X313)

A probability of $3.0 \times 10^{-3}$ failures per cask shifment was used for this event (see event $X 78$ ).

Fuel Fails When Defective Vent Valve Causes LOC (X314)

A probability of $3.0 \times 10^{-3}$ failure per cask shipment was used for this event (see event $\times 78$ ).

(a) An analysis was performed to determine the sensitivity of the total release probability to the probability value used for this event. It was found that increasing this event probability by a factor of 10 raised the total release probability by less than $0.1 \%$. This is well within the overall accuracy of the analysis. 
Puncture Probe Causes LOC from Vent Valve and Fuel Does Not Fail (X315)

The probability that a puncture probe fails the vent valve is assumed to be $4.9 \times 10^{-4}$ per accident (see event $\times 333$ ). The probability of restoring the coolant is assumed to be 0.1 (see event $\times 69$ ). Therefore, a value of $4.9 \times 10^{-5}$ was used for this event.

Fire Causes LOC from Vent Valve and Fuel Does Not Fail (X316)

The probability that a fire accident fails the vent valve is assumed to be $1.0 \times 10^{-2}$ (see event $\times 329$ ). The probability of restoring the coolant is assumed to be 0.1 (see event $\times 69$ ). Therefore, the value used for this event was $1.0 \times 10^{-3}$.

Side Impact Causes LOC from Vent Valve and Fuel Does Not Fail (X317)

A side-impact causing failure of the vent valve was determined in event $\times 330$ to have a probability of $5.9 \times 10^{-6}$. This would result in a loss of cavity coolant. A value of 0.1 was used for the estimated frequency of restoring the coolant (see event $\times 69$ ). Therefore, a probability of $5.9 \times 10^{-7}$ was assigned to this event.

Side Impact Fails Vent Valve Damaged During Handling (X318)

A probability of $2.2 \times 10^{-9}$ per rail car accident was used for this event (see event $\times 268$ ).

Side Impact Fails Improperly Installed Vent Valve (X319)

A probability of $2.2 \times 10^{-9}$ per collision accident was used for this event (see event X269).

Side Impact Fails Defective Vent Valve (X320)

A probability of $6.6 \times 10^{-9}$ per collision accident was used for this event (see event $\times 270$ ).

Fuel Does Not Fail When Improperly Installed Vent Valve Causes LOC (X321)

A probability of 1.0 was used for this event (see event $\times 312$ ). 
Fuel Does Not Fail when Improperly Installed

Vent Valve Causes LOC (X321)

A probability of 1.0 was used for this event (see event $\times 312$ ).

Improperly Installed Vent Valve Causes LOC (X322)

Event $X 261$ gives the failure rate for an improperly installed vent valve based on data from the shipping survey summarized in Section 7 . The survey results did not indicate that loss of coolant occurred due to any handling errors. It is conservatively assumed that $1 \%$ of the improperly installed vent valves would result in significant leakage. The rate for this event was then set at $1.0 \times 10^{-2}$ per shipment. (a)

Defective Vent Valve Installed (X323)

The survey showed that two defective vent valves were installed on casks during the time period covered by the survey. Based on the survey, the probability that a vent will be defective when installed was estimated to be $5.6 \times 10^{-4}$ per cask shipment.

Vent Valve Leaks from Wear Causing LOC (X324)

Information provided on this event in the survey showed that 5 vent valves required replacement due to wear in all of the rail car shipments. This gives an occurrence rate of about $1.4 \times 10^{-3}$ per cask shipment. A rate of $1.0 \times 10^{-2}$ was used for the probability of a worn vent valve causing a loss of coolant (see event $\times 322$ ). The probability of this event was then estimated to be $1.4 \times 10^{-5}$ per shipment. (b)

(a) An analysis was performed to determine the sensitivity of the total release probability to the probability value used for this event. It was found that increasing this event probability by a factor of 10 raised the total release probability by less than $0.1 \%$. This is well within the overall accuracy of the analysis.

(b) An analysis was performed to determine the sensitivity of the total release probability to the probability value used for this event. It was found that increasing this event probability by a factor of 10 raised the total release probability by less than $0.01 \%$. This is well within the overall accuracy of the analysis. 
Vent Valve Damaged During Handling (X325)

No cases of damage to the vent valve during handling were found in the survey. Based on a $50 \%$ confidence limit, a value of $1.9 \times 10^{-4}$ was estimated for this event.

Vent Valve Not Closed Causes LOC (X326)

The survey showed that 2 casks were received with the vent valve not closed. This gives a value of $5.5 \times 10^{-4}$ for the probability of a vent valve being left open. It was learned that none of these occurrences resulted in any loss of coolant. A rate of $1.0 \times 10^{-2}$ was assumed for the probability of an open vent valve resulting in a loss of coolant (see event $\times 322$ ). Thus, the probability of this event was estimated to be $5.5 \times 10^{-6}$ per shipment. (a) Puncture Probe Strikes Vent Valve (X327)

Puncture data summarized in Section 5.6 gives the probability of puncture for large packages based on the package wall thickness. The probability that a puncture probe strikes the vent valve, given that the puncture probe strikes the cask, is based on the projected area of the valve compared to the projected area of the cask. It was estimated that the probability of a puncture probe striking the vent valve would be $3.0 \times 10^{-4}$.

Defective Vent Valve Causes LOC (X328)

A probability of $1.0 \times 10^{-2}$ was used for this event (see event $\times 322$ ). (b)

Fire Temperature and Duration Sufficient to Fail Vent Valve (X329)

The vent valve can withstand temperatures of $400^{\circ} \mathrm{C}\left(750^{\circ} \mathrm{F}\right)$. It is conservatively estimated from the thermal analysis that a 2 -hour fire will cause

(a) An analysis was performed to determine the sensitivity of the total release probability to the probability value used for this event. It was found that increasing this event probability by a factor of 10 raised the total release probability by less than $0.01 \%$. This is well within the overall accuracy of the analysis.

(b) An analysis was performed to determine the sensitivity of the total release probability to the probability value used for this event. It was found that increasing this event probability by a factor of 10 raised the total release probability by less than $0.1 \%$. This is well within the overall accuracy of the analysis. 
failure of the vent valve. From Section 5, it is shown that a 2 -hour fire that could affect the cask has a probability of $1.0 \times 10^{-2}$, which is used for this event.

Side Impact Fails Normal Vent Valve (X330)

Threshold side-impact velocity changes for vent valve were conservatively assumed to be the same as that required to fail the cask seal. It is also assumed that the impact must occur at the location of the drain valve in the cask flange for failure to occur. A value of 0.25 is assumed for the probability of impacting the drain valve. Based on a velocity change of $72 \mathrm{~km} / \mathrm{hr}$ and a side-impact probability of $2.1 \times 10^{-2}$ (see event $\times 85$ ). The probability of this event was then set at $5.9 \times 10^{-6}$ per rail car accident.

End Impact Fails Normal Vent Valve (X331)

The vent valve is located in a finned valve box and is very well protected from end-impact forces. It is assumed that only impacts which would cause a large breach of the cask cavity could fail the vent valve. Therefore, this event was not analyzed and a probability of zero was used.

Damaged Vent Valve Causes LOC (X332)

A probability of $1.0 \times 10^{-2}$ was used for this event (see event $\times 322$ ). (a) Puncture Probe Fails Vent Valve (X333)

The equivalent steel thickness of the vent valve and valve box was estimated to be about $2.5 \mathrm{~cm}$. Based on data in Table 5.2 , it was determined that the frequency of puncture that would fail the vent valve would be approximately $4.9 \times 10^{-4}$ per puncture situation.

(a) An analysis was performed to determine the sensitivity of the total release probability to the probability value used for this event. It was found that increasing this event probability by a factor of 10 raised the total release probability by less than $0.1 \%$. This is well within the overall accuracy of the analysis. 
Overpressure Fails Vent Valve (X334)

It was conservatively assumed that the vent valve would fail if the pressure exceeds the design pressure of the pressure relief device on the cask. From thermal analysis summarized in Section 6.2 it is estimated that the coolant will eventually reach $227^{\circ} \mathrm{C}\left(440^{\circ} \mathrm{F}\right)$ at $2.4 \mathrm{MPa}(350 \mathrm{psi})$ with a fire exceeding 30 minutes. The probability of the fire exceeding 30 minutes was determined to be about 0.05 . Therefore, the occurrence rate of this event was set at $5.0 \times 10^{-2}$ per fire accident.

Fuel Does Not Fail When Vent Valve Leaks from Wear (X335)

A probability of 1.0 was used for this event (see event $\times 312$ ). Fuel Does Not Fail when Vent Valve Is Not Closed (X336)

A probability of 1.0 was used for this event (see event $\times 312$ ). Fuel Fails when Vent Valve Leaks from Wear Causing LOC (X337)

A probability of $3.0 \times 10^{-3}$ failures per cask shipment was used for this event (see event $X 78$ ).

Fuel Fails When Vent Valve Not Closed Causes LOC (X338)

A probability of $3.0 \times 10^{-3}$ failures per cask shipment was used for this event (see event $X 78$ ).

Fuel Fails When Vent Valve Not Closed Causes LOC (X339)

A probability of $3.0 \times 10^{-3}$ failures per cask shipment was used for this event (see event $X 78$ ).

Fuel Does Not Fail When Damaged Vent Valve Causes LOC (X340)

A probability of 1.0 was used for this event (see event $\times 312$ ). Fire Fails Drain Valve and Fuel (X341)

This event is given a value of $1.0 \times 10^{-2}$ (see event $\times 291$ ). 


\section{REFERENCES}

1. 10 CFR Part 71 , Code of Federal Regulations.

2. A. W. Dennis et a1., Severities of Transportation Accidents Involving Large Packages. SAND77-0001, Sandia Laboratories, ATbuquerque, New Mexico, May 1978.

3. Trojan FSAR, Safety Analysis Report.

4. K. J. Eger, A. Hulsey, Operating Experience - Irradiated Fuel Storage. GE Morris Operation, June 1975.

5. Reactor Safety Study - An Assessment of the Accident Risks in U.S. Commercial Nuclear Power Plants. WASH-1400 (NUREG-75/014), U.S. Nuclear Regulatory Commission, Washington DC, October 1975.

6. A. W. Grella, A Review of Five Years' Accident Experience in the U.S. Involving Nuclear Transportation (1971-1975). IAEA-SR-10/5, U.S. Department of Transportation, Washington DC, August 1976.

7. J. W. Langhaar, Transport Experience with Radioactive Materials.

E. I. du Pont de Nemours \& Company, Inc., from CONF-76-0701, July 1976.

8. Environmental Survey of Transportation of Radioactive Materials to and from Nuclear Power Plants. WASH-1238, U.S. Atomic Energy Commission, Washington DC, December 1972.

9. P. J. Pel to and W. L. Purcell, MFAULT: A Computer Program for Analyzing Fau1t Trees. BNWL-2145, Pacific Northwest Laboratory, Richland, Washington, November 1977. 



\begin{abstract}
APPENDIX G
POTENTIAL RELEASES FROM A TRAIN TRANSPORTED SPENT FUEL CASK DURING POSTULATED ACCIDENT CONDITIONS
\end{abstract}


APPENDIX G

POTENTIAL RELEASES FROM A TRAIN TRANSPORTED SPENT

FUEL CASK DURING POSTULATED ACCIDENT CONDITIONS

\section{G.1 FACTORS INFLUENCING AIRBORNE RELEASE}

In the unlikely event of an accident severe enough to release activity from a spent fuel cask, the material, its dispersability and the time of release are of concern. Many factors influence the airborne release of activity from a spent fuel cask. Some, but not necessarily all, are as follows:

- physical and chemical characteristics of the source material and how it is altered during and after the accident

- container design and post-accident integrity, and

- corrective action taken by persons at the accident scene.

Estimates of the potential releases under postulated accident conditions can be obtained in several ways. The best way to estimate releases would be to use values derived from actual accident experience under similar circumstances. Such data are not available since no releases have occurred. Thus, the data from other than actual accidents must be used. There are two sources of data that can be used; that derived from experimental simulations and that developed from the known chemical and physical responses of the materials involved. The former is preferable since it can encompass some of the conditions postulated for the accident. However, accidents are unique events and cannot be exactly duplicated, so engineering judgment is required to arrive at realistic estimates.

An additional consideration in the quantification of releases is their ultimate use. Release fraction values are only an intermediate step in the assessment of the potential consequences to man. Other physical processes which are influential in determining the quantity of airborne material that affects man are atmospheric transport and respiration rate. Both of these 
processes are sensitive to the size of airborne radioactive particles. It is not within the scope of this appendix to discuss either topic, but there are size 1 imitations under various conditions for both. $(1,2,3)$ Considering both processes, the significant size fraction of assumed particulate releases was assumed to be less than $10 \mu \mathrm{m}$ Aerodynamic Equivalent Diameter. (a)

\section{G.2 POTENTIAL RELEASES}

This section summarizes the existing fractional airborne release information applicable to radioactive fission products.

Migration of volatile fission products radially outward to the cooler cladding under reactor conditions is one mechanism of release from the fuel matrix. In the absence of chemical reactions or mechanical damage, the migrated elements are the total potential release. Davies et al. (4) analyzed cladding deposits on rods from a BWR element which was ramped at high power to failure. Table G.l shows an enhancement factor for the listed fission products over what was expected from peripheral burnup. The extent of fission product release is dependent on reactor operating parameters. Total burnup and linear heat rate histories are important in the generation and release of fission products from the fuel pellets. (5) While these migrated elements represent a potential release, a driving force is necessary for their escape from the fuel cladding. Realistic mechanisms are selective in the radionuclides that are released and would allow only a small fraction of the total gap inventory to escape the cladding.

Fission product release from a spent fuel element in a cask would probably occur continuously until the system cooled following postulated accidents severe enough to cause damage. Release rates from the fuel would vary over wide limits depending on system temperatures, fission product properties, and the physical condition of the fuel following the accident. It is possible to identify four conditions at which major driving forces for release exist. These periods of high rates would account for most of the total release.

(a) Behaves in air as a sphere of unit density of the stated size. 
TABLE G.1. Analysis of Cladding Deposits ${ }^{(4)}$

\begin{tabular}{|c|c|c|c|}
\hline Element & $\begin{array}{c}\text { Concentration } \\
\text { Observed } \\
(\mu \mathrm{gm} / \mathrm{gmU}) \\
\end{array}$ & $\begin{array}{l}\text { Predicted } \\
(\mu \mathrm{gm} / \mathrm{gmU}) \\
\end{array}$ & $\begin{array}{l}\text { Enhancement } \\
\text { Factor } \\
\end{array}$ \\
\hline Cesium & 119,000 & 1,940 & 61 \\
\hline Tellurium & 42,600 & 318 & 134 \\
\hline Barium & 20,000 & 995 & 20 \\
\hline Iodine & 11,600 & 201 & 58 \\
\hline Cadmium & 2,700 & 41.2 & 66 \\
\hline Cerium & 2,410 & 2,150 & 1.1 \\
\hline Palladium & 1,030 & 669 & 1.5 \\
\hline Tin & 629 & 34.3 & 18 \\
\hline Silver & 567 & 45.9 & 12 \\
\hline Strontium & 577 & 671 & 0.9 \\
\hline
\end{tabular}

The four fission product release mechanisms outlined below describe the macroscopic pathways of radionuclide escape from spent fuel elements. Diffusion from the fuel is ignored due to the relatively low temperatures (for solid diffusion) during normal transport conditions and the short high temperature periods of accident conditions.

A fifth release mechanism, crud release, is different from the other mechanisms because no fission products are released. In this case, only corrosion products or crud plated on the outside clad surfaces are released.

Retention of radionuclides in the cask cavity is discussed, but is generally difficult to quantify because performance under actual accident conditions is unknown. Conservative assumptions were made to compensate for the uncertainties.

A PWR fuel element is used as the basis for accident source terms in this study. This is conservative for two reasons:

1. The cask can carry 3.7 MgHM of BWR fuel and 3.22 MgHM of PWR fuel.

2. The BWR elements can tolerate higher temperatures before rupture. 


\section{Gap Release}

Gap release is the energetic venting of pressurized gases from the fuel element plenum and pellet-cladding gap. High temperature creep or mechanical forces may cause the necessary cladding rupture in a spent fuel cask. Available for release are a fraction of the noble gases, volatile halogens and entrained particulates that have migrated from the fuel during irradiation.

Mathematical models exist for predicting fission gas releases from the fuel pellets in the reactor. Beyer and Hann $(7)$ with burnup correction factors predict an $8 \%$ release of the noble gases to the gap from high power $(49.2 \mathrm{~kW} / \mathrm{m}$ $15 \mathrm{~kW} / \mathrm{ft}$ ) PWR rods irradiated to $30,000 \mathrm{MWd} / \mathrm{Mg}$. To account for rough handling (fuel pellet fractures) and unusual reactor operating conditions, a $30 \%$ release of krypton and xenon was used. Regulation Guide 1.25 suggests this value for krypton. A release of $10 \%$ is given for fission product iodine and tritium. Table G.2 summarizes gap inventories available for outgassing.

FIGURE G.2. Fraction of Nuclides Available for Release During Outgassing from the Pellet-Cladding Gap

\begin{tabular}{|c|c|}
\hline Isotope & Fraction \\
\hline $\mathrm{Kr}$ & 0.3 \\
\hline$x_{e}$ & 0.3 \\
\hline$I$ & 0.1 \\
\hline $3_{H}$ & 0.1 \\
\hline \multicolumn{2}{|l|}{$\operatorname{AQFP}(\mathrm{a})$} \\
\hline (Impact Failures) & $10^{-6}$ \\
\hline (Creep Rupture) & $2.0 \times 10^{-5}$ \\
\hline \multicolumn{2}{|l|}{ Actinides (a) } \\
\hline (Impact Failures) & $10^{-6}$ \\
\hline (Creep Ruptures) & $2.0 \times 10^{-5}$ \\
\hline \multicolumn{2}{|l|}{${ }^{14} \mathrm{C}$} \\
\hline (Impact Failures) & $10^{-6}$ \\
\hline (Creep Ruptures) & $2.0 \times 10^{-5}$ \\
\hline
\end{tabular}

(a) Assume sub $10 \mu \mathrm{m}$ fines. 
A11 Other Fission Products (AOFP), Actinides and Carbon-14 are assumed to be released after an impact or pressurized cladding rupture as particles. The release fraction for impact failures is estimated from work by Smith and Ross. ${ }^{(8)}$ Breakup and release of vitreous high level waste from stainless stee 1 canisters during impact was studied. For an $128.8 \mathrm{~km} / \mathrm{hr}$ (80-mph) test, less than $0.1 \%$ of the material was broken into sub-10 $\mu \mathrm{m}$ fines. In no case was any weight change detected (detection 1 imit $0.017 \%$ ) due to material escaping the canister. For impact fuel failures in this study, it was assumed $0.1 \%$ of the fines are released as sub-10um particles. Recent tests have been run to measure releases from fuel elements failed by high temperature creep rupture.

Information from R. A. Lorenz at Oak Ridge National Laboratory (September 1977 ) indicates that at $900^{\circ} \mathrm{C}$ up to $0.02 \%$ of the fuel in the form of fines may be released during high pressure venting. According to Lorenz (October 1977), ninety per cent of this material settled out near the rupture point, which leaves $0.002 \%$ available for release in the cask cavity. This value will be used for creep failures in this study. Cubiccoiotti et al. (9) reports that $\mathrm{UO}_{2}$ dust is ejected from fuel in the reactor due to radiation damage.

Advanced fuel designs reduce the 1 inear heat rate and therefore the fission product release. Gap inventories in future fuels may be less than those specified in this study. Actual measurements of fission gas release have been made on fuel irradiated at less than $32.8 \mathrm{~kW} / \mathrm{m}(10 \mathrm{~kW} / \mathrm{ft})$ to $31,000 \mathrm{MWd} / \mathrm{Mg}$. Lorenz et al. (10) examined krypton and xenon releases from irradiated fuel elements and found that less than $2 \%$ of the generated gases were released.

The final barrier to atmospheric release is the cask shell. If this containment is breached, essentially all of the noble gases released from the failed fuel elements escape. Iodine would probably be partially retained in the cask cavity but is conservatively assumed to totally escape. For the case of a fire with no breach of the cask except for the pressure relief valve, $50 \%$ retention of particulates is assumed. This value was calculated assuming that the driving forces for escape were the release of pressurized gases and expansion due to heating of steam in the cask cavity. 
Vaporization Release

Fission products are released from ruptured fuel elements at elevated temperatures. Low melting point solids volatilize and leave the fuel in gaseous form. If the high temperature environment occurs before cladding failure, then a driving force for release is the venting of internal pressures. For low temperature cladding failures followed by heating, vapor pressures and diffusion cause the release.

Cesium is a primary constituent of the semi-volatile elements. It is estimated that $0.06 \%(11)$ of the total is present as metallic cesium on void boundaries before a pressurized element ruptures and that $50 \%$ escapes the cladding. This same fraction $(0.03 \%)$ is conservatively used for passive outgassing following an impact failure and subsequent overheating.

Recent experimental results indicate the conservative nature of the estimates. Lorenz et al ${ }^{(12)}$ measured cesium release during the heating of predrilled high burnup fuel to be less than $6.7 \times 10^{-4} \%$. Osborne and Parker (13) tested rods to failure which were irradiated to $7,000 \mathrm{MVd} / \mathrm{Mg}$ and noted releases of $10^{-2} \%$ to $10^{-3} \%$. Lorenz (September 1977 ) indicated that $0.03 \%$ of the cesium was vented during pressurized rupture of fuel elements.

Partial retention of cesium in the cask cavity is likely. Mechanisms of condensation and plate out or chemical reactions with other materials have been studied. Release attenuation due to these actions is variable and difficult to quantify, therefore is not used. However, since cesium is a particulate at the lower cask temperatures, cask retention described for the gap particulates was used.

Leach Release

Leaching of fission products from the fuel pellets requires direct contact of aqueous cask cavity coolant. Contact can occur following an impact which ruptures fuel pins while the cask retains its cavity coolant. Also, undetected failed fuel (fuel which outgasses in the reactor, but is not detected and overpacked in the spent fuel basin) can release a small amount of fission products to the cask coolant under normal transport conditions. 
Releases from fuel contacted by the coolant after an impact failure are presented in Table G.3. The one day and one week data comes from a slowleach test in deionized water of fuel pellets irradiated to $54,450 \mathrm{MWd} / \mathrm{MgU}$. The releases are conservative since the samples were broken fuel fragments, had free contact with a flowing leachant and enhanced fission product availability due to the high burnup. The one-hour leach releases are outside the experimental data, but were calculated using a logarithmic mechanism model presented in the study. The value listed for all other fission products is based on strontium data. Actinides leached from the pellets are based on plutonium. Ten percent of the fuel in the rods broken by an end-on impact was assumed available for leaching. (15)

TABLE G.3. Fraction of Spent Fuel Constituents Released to Coolant (Deionized Water)

\begin{tabular}{|c|c|c|c|}
\hline & 1 Hour $(a)$ & 1 Day & 1 Week \\
\hline Cs & $2 \times 10^{-4}$ & $5.5 \times 10^{-4}$ & $1.2 \times 10^{-3}$ \\
\hline$A_{A F P}(b)(S r)$ & $3 \times 10^{-5}$ & $7.5 \times 10^{-5}$ & $1.5 \times 10^{-4}$ \\
\hline Actinides (Pu) & $2 \times 10^{-5}$ & $6 \times 10^{-5}$ & $1.5 \times 10^{-4}$ \\
\hline
\end{tabular}

(a) All other fission products.

(b) Calculated from the general equation given in Ref. 14: Release Fraction $=B t^{n}$ where $t$ is time, and the two isotope constants $B$ and $n$ were given.

Retention of leached radionuclides depends on the integrity of the cask. The cask coolant can escape either as a vapor during venting or as a liquid due to a cask breach. Vaporization external to the cask of the release liquid could also take place. For coolant that escapes the cask and remains a liquid, $1 \%$ of the contained activity is assumed to escape as an aerosol. If an external fire is present, $10 \%$ may be in the aerosol. (15) Vaporized coolant vented from the cask is assumed to release all contained activity as sub $10 \mu \mathrm{m}$ particulates. 


\section{Oxidation Releases}

Oxidation of some fraction of the $\mathrm{UO}_{2}$ fuel pellets to $\mathrm{U}_{3} \mathrm{O}_{8}$ may take place in the unlikely event of a large cask rupture. Increased releases of fission products occur by this mechanism due to a large increase in surface area. The reaction proceeds at insignificant rates in a steam atmosphere. (16) Therefore, a cask breach large enough to allow flowing air to contact the fuel is necessary for this type release.

Experimental data indicate that the rate of oxidation controls the process. After complete oxidation, additional releases were not observed. This study assumed all material contacted by the air is completely oxidized in 90 minutes at $700^{\circ} \mathrm{C}$. Table G.4 ${ }^{(17)}$ gives release fractions under these conditions. The data are based on fuel irradiated to $7000 \mathrm{MWd} / \mathrm{Mg}$ heated in air for 90 minutes. The value for all other fission products is based on strontium data. Releases of actinides are assumed negligible because of their low oxidation potential in the fuel matrix.

TABLE G.4. Fission Product Release from PWR-Type UO Irradiated to $7000 \mathrm{MWd} / \mathrm{Mg}$ and Heated in $\mathrm{Air}$ to $700^{\circ} \mathrm{C}$ for 90 Minutes

\section{Fission Product Percent Release}

$\begin{array}{ll}\mathrm{Kr}, \mathrm{Xe} & 6.0 \\ \mathrm{I} & 15 \\ { }^{\mathrm{H}} & 15 \\ \mathrm{CS} & <0.005 \\ \mathrm{Ru} & 0.1 \\ \mathrm{AOFP}(\mathrm{a}) \text { (Sr) } & <0.0005 \\ { }^{14} \mathrm{C} & <0.0005\end{array}$

(a) A11 other fission products.

Containment by the cask of oxidation released fission products is not postulated. Some hold up of the fines is possible, but due to the initiating event of a large cask breach this factor cannot be quantified. However, only 
fuel pellets contacted by flowing air will be oxidized. For this study, $10 \%$ of the fuel rods broken by an end-on impact were available for oxidation. The release is assumed to be in the form of sub $10 \mu \mathrm{m}$ particles and gases. Crud Release

The crud release mechanism involves the release of corrosion products or crud by impact or by a severe rapid thermal transient. Since the crud is affixed to the external clad surfaces, no cladding rupture is necessary. As a result, crud would be expected to be released in most severe transportation accidents.

The amount of crud released in an accident has not been determined experimentally. It was assumed in Reference 18 that about $20 \%$ of the adhered crud could be removed by physical shock. Judgments made at a recent workshop at Sandia Laboratories (1980) indicate that about $25 \%$ of the crud that plates on the spent fuel rods during reactor operation and contaminates the spent fuel cask cavity surfaces is loosely adhering. The remainder adheres tightly and requires abrasion and chemical treatment to be removed. Consequently for this study, $25 \%$ of the crud is assumed to be knocked loose in an impact accident. The total crud released to the cask cavity is assumed to be 0.25 of the entire crud inventory on the spent fuel or the cavity walls. Cobalt-60 is the primary isotope considered in the crud release mechanism. Since cobalt is a particulate, $50 \%$ retention in the cask cavity is assumed to be consistent with the assumption for gap release particulates.

\section{G.3 RELEASE CATEGORIES}

In order to define the various releases that might occur, a series of release categories for both 180-day and 4-year cooled fuel were identified for the postulated types of accident conditions or failure of the cask system. Brief descriptions of the various physical processes that define each release category are presented in this sction.

Releases from postulated accidents involving the train transport of spent fuel are reported as fractions of the cask inventory. Radioactivity releases are reported in curies of activity released. Various failure mode fractions for the fuel elements are defined as follows: 
$X=$ Fraction broken on impact

$Y=$ Fraction fail by creep rupture

180-Day Cooled Fuel (Cask Contains Cavity Coolant)

1. Small, Undetected Leakage of Cavity Coolant (15)

Assume that a rail cask is shipped with an undetected leak of cavity coolant. Due to previously failed fuel which is available for leaching, the cavity coolant is contaminated to a level of $1 \mu \mathrm{Ci} / \mathrm{cc}$ with mixed fission products, primarily ${ }^{137} \mathrm{Cs}$. The cask water volume is estimated to be $2.3 \times 10^{6} \mathrm{cc}$ so the contained activity would be $2.3 \mathrm{ci}$. The largest leak that would go undetected is estimated to be $0.001 \mathrm{cc} / \mathrm{sec}$. One percent of the released activity is assumed to escape to the atmosphere as a sub $10 \mu \mathrm{m}$ aerosol at ground level.

2. Slow Leak of Cavity Coolant Due to a Gasket Failure

A gasket in the rail cask, which retains the cavity coolant, fails in transit. A leak 1,000 times larger than Case 1 or $1 \mathrm{cc} / \mathrm{sec}$ continues, for four hours until discovered. The coolant contains $1 \mu \mathrm{Ci} / \mathrm{Cc}$ of ${ }^{137} \mathrm{Cs}$. One percent of the activity which escapes the cask is released to the atmosphere as a sub $10 \mu \mathrm{m}$ aerosol at ground level.

3. Impact and Leak of Cavity Coolant

The rail cask is involved in an impact which causes some fuel element failures and a leak of cask cavity coolant to the ground. Ten percent of the fuel in the broken rods is contacted by the cavity coolant. Particulates released from the gap (AOFP) would also be absorbed in the coolant. The leak rate is assumed to be $100 \mathrm{cc} / \mathrm{sec}$. Atmospheric releases are the gaseous gap release fractions ( $\mathrm{Kr}, \mathrm{Xe}, \mathrm{I})$ in Table $\mathrm{G} .2$ and $1 \%$ of the activity in the escaping coolant.

One-half of the coolant would drain out of the cask in about 1-1/2 hours. As the water drains away from the fuel, some rods will lose their cooling capacity. Self-heating to failure could occur. Failures could be avoided by retrieving the cask and implementing emergency measures to stop the coolant leakage. Activity released from the cask following the accident 
is listed below. The coefficient in the release to the coolant is due to the holdup in the cask. A factor is needed to convert the leach data and gap activity to a fraction released per hour from the cask. The fraction of crud released to the cask cavity is 0.25 and $1 \%$ of the activity in the escaping coolant is assumed to be released to the atmosphere.

- Gap ( $\mathrm{Kr}, \mathrm{Xe}, \mathrm{I}, 3_{\mathrm{H} \text { only)}}{ }^{(\mathrm{a})}$ - (Table G.2 fractions - Impact Failure) X.

- Coolant ${ }^{(b)}-2.3 \times 10^{-1} \times t$ [0.1 (Activity in Table G.3 - 1 day)] + (AOFP, Actinides and ${ }^{14} C$ in Table G.2 - Impact Failures). $t=$ time of leak termination (hours) $0<t<6$.

- Volatiles (cesium - 0.0003).

- Crud $-{ }^{60}$ Co $(0.25 \times 0.5 \times 0.01)$ (percent of cask coolant released) $x$.

4. Severe Cask Impact With a Rapid Loss of Cavity Coolant

The postulated impact is severe enough to rupture the cask and all fuel cladding. This results in an immediate loss of coolant and air is admitted to the cask cavity. Thermal analysis for the cask (Case 5, Appendix D) indicates that $50 \%$ of the fuel would reach temperatures above $570^{\circ} \mathrm{C}\left(1050^{\circ} \mathrm{F}\right)$ in about eight hours.

Releases from this accident are due to the loss of coolant, impact releases of the gap activity, volatilization of available cesium, and oxidation of exposed pellets. The eight-hour releases are as follows:

- Gap ${ }^{(c)}$ - (Table G.2 fractions - Impact Failure) 1.

- Coolant ${ }^{(b)}-2.3 \mathrm{Ci}$ of mixed fission product (primarily ${ }^{137} \mathrm{Cs}$ ).

- Volatiles(c) (cesium) - 0.0003 .

- Oxidation ${ }^{(c)}-0.1$ (Table $G .4$ fractions) $x$.

- Crud - $(0.25 \times 0.01)$

This accident postulates an accidental fire external to the cask-railcar.

(a) Gaseous release at ground level.

(b) $1 \%$ of activity released to atmosphere as a sub $10 \mu \mathrm{m}$ aerosol at ground 1 evel.

(c) Nongaseous fission products released as sub $10 \mu \mathrm{m}$ fines at ground level. 


\section{Cask Involved in Fire}

This accident postulates an accidental fire external to the cask-train system. No impact forces are involved. Thermal analysis (Appendix D) indicates that the cask coolant would be lost: 1) for a 1/2-hour fire, about 10 hours after the fire starts; and 2) for a 2-hour fire, about 2 hours after the fire starts. Fuel would reach $570^{\circ} \mathrm{C}\left(1050^{\circ} \mathrm{F}\right)$ in 5 hours for the 2-hour fire. Fuel elements begin to creep rupture at this time. (a)(5) Fifty percent of the fuel elements would fail. No crud is assumed to be relased in this case since the transient is not severe enough to cause release and there is no impact.

During this accident, the cask releases the cavity coolant, all gap invencries and volatile cesium as follows:

- Gap ${ }^{(b, c)}$ - (Table G.2 fractions - Creep Rupture) x 0.5 .

- Coolant ${ }^{(d, e)}-0.19$ Ci of mixed fission products (primarily ${ }^{137} \mathrm{Cs}$ ).

- Volatiles $(b, c, d)$ (cesium) - 0.0003 .

6. Cask Impacted Followed by $1850^{\circ} \mathrm{F}$ Fire

This accident is the combination of an impact which may fail a fraction of the fuel elements followed by a $2-\mathrm{hr} 1010^{\circ} \mathrm{C}\left(1850^{\circ} \mathrm{F}\right)$ fire. No releases are postulated until the pressure relief valve vents the vaporized coolant after 2 hours, leaving a steam atmosphere in the cask. The coolant contains al1 nuclides leached from 10\% of the impact-failed fuel elements. Fission gases from broken rods are also vented. The remaining unfailed fuel reaches perforation temperatures and fails between 1.9 and 2.6 hours after the fire begins. Cesium isotopes are volatilized from all failed fuel elements. The releases are as follows:

- $\operatorname{Gap}(e, c)$ - (Table G.2 fractions - Impact Failure) X. $(b, c)$ - (Table G.2 fractions - Creep Rupture) $Y$.

- Coolant $(d, e)-0.1$ (Table G.3 fractions - 1 hour) $X$.

(a) Based on a calculation of stresses due to internal pressure. Ten-hour creep failure data used for material properties. Conservatively assumed immediate failure upon reaching $570^{\circ} \mathrm{C}\left(1050^{\circ} \mathrm{F}\right)$.

(b) Released after fire extinguished at ground level.

(c) Half of these particulates remain in the cask.

(d) Activity released as sub $10 \mu \mathrm{m}$ fines.

(e) Released to fire plume. 
- Volatiles $(a, b, c)$ (cesium) - 0.0003 .

- Crud $^{(d)}-{ }^{60}$ Co $-(0.25 \times 0.5 \times 0.1)$ (percent coolant released) $x$.

7. Severe Cask Impact Followed by an $1010^{\circ} \mathrm{C}\left(1850^{\circ} \mathrm{F}\right)$ Fire

The postulated impact in this accident is severe enough to cause a large breach in the cask and fail all fuel elements. Air is allowed into the cavity. The coolant is immediately lost to the ground. Fission gases from all rods are vented. The fire causes the fuel to reach volatilization temperatures in 2.5 to 3 hours. Exposed fuel pellets are oxidized and cesium is volatilized from all failed fuel. The releases are as follows:

- Gap (e) - Table G.2 fractions - Impact Failure.

- Coolant - $0.19 \mathrm{Ci}$ (mixed fission products primarily ${ }^{137} \mathrm{Cs}$ ). Assume $10 \%$ of the activity is released to the fire plume as an aerosol.

- Volatiles (cesium) $(b, f)-0.0003$.

- Oxidation $^{(b, f)}-0.1$ (Table G.4 fractions).

- Crud $^{(f)}-{ }^{60}$ Co $-(0.25 \times 0.1)$.

8. Rapid Loss of Cavity Coolant Due to Cask Closure Device Failure A cask accident which fails a cask closure device other than the head is possible. An example of this would be a valve failure. The cask was conservatively assumed to be in an orientation which allows complete draining of the cavity coolant to the ground. Thermal analysis for this cask indicates perforation temperatures $570^{\circ} \mathrm{C}\left(1050^{\circ} \mathrm{F}\right)$ would be reached in about 5 hours by self-heating. Fifty percent of the fuel elements would fail within 10 hours of the accident. This accident may release the gap activity, coolant, and volatile elements as follows:
(a) Half of these particulates remain in the cask.
(b) Released after fire extinguished at ground level.
(c) Activity released as sub $10 \mu \mathrm{m}$.
(d) $10 \%$ of activity is released to fire plume.
(e) Released to fire plume.
(f) Released as sub $10 \mathrm{\mu m}$ particles. 
- Gap ${ }^{(a)}$ - (Table G.2 fractions - Creep Rupture) $\times 0.5$.

- Coolant ${ }^{(b)}-0.19 \mathrm{Ci}$ of mixed fission products (primarily ${ }^{137} \mathrm{Cs}$ ).

- Volatiles $(c, a)$ (cesium) - 0.0003 .

Long Cooled Fuel (4 Years, Dry Cask)

1. Impact (Smal1 Breach)

The rail cask is involved in an impact which causes a small breach of the cask and failure. Particulates released from the gap (AOFP) would be released from the cask. Atmospheric releases are the gaseous gap release fractions $(\mathrm{Kr}, \mathrm{Xe}, \mathrm{I})$ in Table G.2.

Activity released from the cask is listed below.

- Gap ( $\mathrm{Kr}, \mathrm{Xe}, \mathrm{I},{ }^{3} \mathrm{H}$ only) ${ }^{(\mathrm{d})}$ - (Table G.2 fractions - Impact Failure) X.

2. Severe Cask Impact

The postulated impact is severe enough to rupture the cask and all fuel

cladding. This results in air being admitted to the cask cavity.

Releases from this accident are due to impact releases of the gap activity.

The releases are as follows:

- Gap (e) - (Table G.2 fractions - Impact Failure).

3. Cask Involved in an $1850^{\circ} \mathrm{F}$ Fire

This accident postulates an accidental fire external to the cask-rail car system. No impact forces are involved. Fuel is estimated to reach $570^{\circ} \mathrm{C}$ $\left(1050^{\circ} \mathrm{F}\right)$ in about $2-1 / 2$ to 3 hours for a 2 -hour or longer fire. Fuel elements begin to creep rupture at this time. $(f)(5)$

(a) Half of these particulates will remain in the cask.

(b) $1 \%$ of this activity released as an aerosol at ground level.

(c) Released as sub $10 \mu \mathrm{m}$ particles at ground leve1.

(d) Gaseous release at ground level.

(e) Nongaseous fission products released at sub $10 \mu \mathrm{m}$ fines at ground level.

(f) Based on a calculation of stresses due to internal pressure. Ten-hour creep failure data used for material properties. Conservatively assumed immediate failure upon reaching $570^{\circ} \mathrm{C}\left(1050^{\circ} \mathrm{F}\right)$. 
During this accident, the cask releases all gap inventories and volatile cesium as follows:

- Gap $(a, b)$ - (Table G.2 fractions - Creep Rupture).

- Volatiles $(a, b, c)$ (cesium) - 0.0003 .

4. Cask Impacted Followed by $1010^{\circ} \mathrm{C}\left(1850^{\circ}\right)$ Fire

This accident is the combination of an impact which may fail a fraction of the fuel elements followed by an $1010^{\circ} \mathrm{C}\left(1850^{\circ} \mathrm{F}\right)$ fire. Fission gases from broken rods are vented. The remaining unfailed fuel reaches perforation temperatures and fails more than $2-1 / 2$ to 3 hours after the fire begins for a 2-hour or longer fire. Cesium isotopes are volatilized from all failed fuel elements. The releases are as follows:

- Gap $(d, b)$ - (Table G.2 fractions - Impact Failure) X. $(b, a)$ - (Table G.2 fractions - Creep Rupture) Y.

- Volatiles $(a, d, c)$ (cesium) - 0.0003 .

5. Severe Cask Impact Followed by an $1010^{\circ} \mathrm{C}\left(1850^{\circ} \mathrm{F}\right)$ Fire

The postulated impact in this accident is severe enough to cause a large breach in the cask and fail all fuel elements. Air is allowed into the cavity. Fission gases from all rods are vented. The fire causes the fue 1 to reach volatilization temperatures in about 2-1/2 to 3 hours for a 2-hour fire. Exposed fuel pellets are oxidized and cesium is volatilized from all failed fuel. The releases are as follows:

- Gap ${ }^{(d)}$ - (Table G.2 fractions - Impact Failure)

- Volatiles (cesium) $(e, a)-0.0003$

- Oxidation (e,a) -0.1 (Table G.4 fractions) 1.

- Crud - ${ }^{60}$ Co $-(0.25 \times 0.01)$

(a) Released after fire extinguished at ground level.

(b) Half of these particulates remain in the cask.

(c) Activity released as sub $10 \mu \mathrm{m}$ fines.

(d) Released to fire plume.

(e) Released as sub $10 \mu \mathrm{m}$ particles. 


\section{REFERENCES}

1. "Report of Task Group and Lung Dynamics to ICRP Committee 2. Deposition and Retention Models for Internal Dosimetry to Human Respiratory Tract." Health Physics, 12:173, 1966.

2. D. H. Slade, Meteorology and Atomic Energy, 1968. USAEC Division of Technical Information, July 1968.

3. E. J. Katz, "Atmospheric Diffusion of Settling Particles with Sluggish Response." Journal of Atmospheric Sciences, 23:159, 1966.

4. J. H. Davies et a1., Irradiation Tests to Characterize the PCI Failure Mechanism. NED0-21551, pp. 38-42, General Electric Company, San Jose, California, February 1977.

5. C. W. Smith, Calculated Fuel Rod Perforation Temperatures Commercial Power Reactor Fuels. NEDO-10093, p. 5, General Electric Company, San Jose, California, September 1969.

6. Reference 5, p. 9 .

7. C. E. Beyer and C. R. Hann, Prediction of Fission Gas Release from $\mathrm{UO}_{2}$ Fuel. BNWL-1875, Pacific Northwest Laboratory, Richland, Washington, November 1974.

8. T. H. Smith and W. A. Ross, Impact Testing of Vitreous Simulated High-Level Waste in Canisters. Pacific Northwest Laboratory, Richland, Washington, May 1975.

9. D. Cubiccoiotti et al, The Nature of Fission-Product Deposits Inside Light-Water-Reactor Fuel Rods. p. 96, Stanford Research Institute, Menlo Park, California, November 1976.

10. R. A. Lorenz et al, Quarterly Progress Report on Fission Product Release from LWR Fuel for the Period October-December 1976. ORNL-NUREG-TM-88, p. 29, Oak Ridge Nationa1 Laboratory, Oak Ridge, Tennessee, March 1977.

11. Potential Releases of Cesium from Irradiated Fuel in a Transportation Accident. NUREG-0069, D. 14, U.S. Nuclear Regulatory Commission, Washington DC, July 1976.

12. Reference 10, p. 24 .

13. Nuclear Safety Program: Annual Progress Report for the Period Ending December 31, 1970. ORNL-4647, p. 46, Oak Ridge Nationa 7 Laboratory, Oak Ridge, Tennessee, May 1971. 
14. Y. B. Katayama, Leaching of Irradiated LWR Fuel Pellets in Deionized and Typical Ground Water. BNWL-2057, Pacific Northwest Laboratory, Richland, Washington, July.

15. Environmental Survey of Transportation of Radioactive Materials to and from Nuclear Power Plants. WASH-1238, U.S. Atomic Energy Commission, p. 44, Washington DC, December 1972.

16. G. W. Parker et a1., Out-of-Pile Studies of Fission-Product Release from Overheated Reactor Fuels at ORNL, 1955-1965. ORNL-39810, p. 85, Oak Ridge National Laboratory, Oak Ridge, Tennessee, July 1967.

17. Reference 16, pp. 85-92.

18. N. C. Finley et al. Transportation of Radionuclides in Urban Environs: Draft Environmental Assessment. NUREG/CR-0743, p. 49, Sandia National Laboratories, Albuquerque, New Mexico, July 1980. 


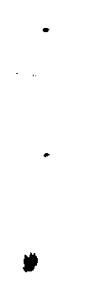

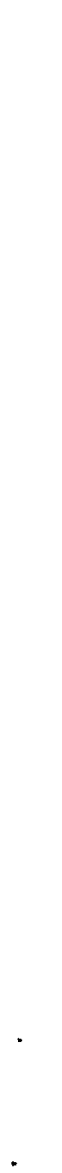

2 


\section{APPENDIX $H$}

SIGNIFICANT RADIONUCLIDES

IN SPENT FUEL 
APPENDIX H

SIGNIFICANT RADIONUCLIDES IN SPENT FUEL

The potential radioactive sources including fission products and actinides in the spent fuel at the time of shipment were obtained from analyses performed with the ORIGEN ${ }^{(1)}$ computer program. The set of equations describing the formation, transmutation, and decay of nuclides from a nuclear reactor is approximated by ORIGEN as a homogeneous set of simultaneous first-order ordinary differential equations with constant coefficients. Rigorously, the set of equations is nonlinear since the neutron flux varies as the composition of the fuel changes at constant power. However, this variation with time is small, and the neutron flux can be considered constant over short time intervals, thus permitting the linear approximation. ORIGEN solves this set of equations by the matrix-exponential method. Radionuclide inventories were calculated by means of the ORIGEN program for a 1,200-MNe reference reactor operated $70 \%$ of the time to produce 0.84 GWe of electricity per year.

Inventories were calculated for an equilibrium core at a burnup of 29,000 megawatt-days per magagrams of uranium charged. The fuel was assumed to decay for 180 days at which time it is shipped in spent fuel casks. For long-cooled fuel, the decay time was assumed to be 4 years.

A nuclear reactor that has operated for many hundreds of hours contains several hundred different radionuclides - almost the full range of the chart of the nuclides. Not all these radionuclides need be considered in the calculation of exposure from an accidental release. With very little decrease in the accuracy of the calculated consequences, the number of radionuclides considered can be reduced significantly.

The elimination of radionuclides from consideration in radiation dose calculations was based on a number of parameters, such as quantity (curies), release fraction, radioactive half-life, emitted radiation type and energy, and chemical characteristics. In addition, it is possible to eliminate radionuclides with half-lives shorter than 15 days. 
Since storage is assumed for 180 days, any nuclide with half-lives shorter than 15 days would have negligible activity after 10 or more half-lives had passed.

These el iminations resulted in the 1 ist of 24 radionuclides presented in Table H.1, which gives their activity at the time the spent fuel is assumed to be shipped. The table shows the radioactive inventory in the fuel in terms of curies per magagrams of heavy metal. These values were converted to the fuel assembly inventory by multiplying the amount of heavy metal per fuel element, (0.46 MgHM per PWR element). Table H.2 shows the significant radionuclides present in the spent fuel after 4 years of storage.

\section{REFERENCES}

1. M. J. Bell, ORIGEN, The ORNL Isotope Generation and Depletion Code. ORNL-4628, Oak Ridge Nationa 7 Laboratory, Oak Ridge, Tennessee, 1973. 
TABLE H.1. Significant Fission Products in Spent PWR Fuel (180 days after discharge)

\begin{tabular}{|c|c|c|c|c|}
\hline No & Isotope & $\begin{array}{c}\text { Radioactive } \\
\text { Inventory } \\
\text { Source } \\
\text { (Ci/MgHM) } \\
\end{array}$ & $\begin{array}{c}\text { Fuel } \\
\text { Assembly } \\
\text { Inventory } \\
\text { (Ci) } \\
\end{array}$ & $\begin{array}{c}\text { Half-L ife } \\
\text { (days) } \\
\end{array}$ \\
\hline 1 & Tritium & $4.4 \times 10^{2}$ & $2.0 \times 10^{2}$ & 4,511 \\
\hline 2 & Carbon $14^{(\mathrm{a})}$ & $7.4 \times 10^{-1}$ & $3.4 \times 10^{-1}$ & $2.1 \times 10^{6}$ \\
\hline 3 & Krypton 85 & $9.5 \times 10^{3}$ & $4.4 \times 10^{3}$ & 3,950 \\
\hline 4 & Strontium 89 & $5.5 \times 10^{4}$ & $2.5 \times 10^{4}$ & 52.1 \\
\hline 5 & Strontium 90 & $6.7 \times 10^{4}$ & $3.1 \times 10^{4}$ & 11,030 \\
\hline 6 & Yttrium 91 & $9.5 \times 10^{4}$ & $4.4 \times 10^{4}$ & 59.0 \\
\hline 7 & Zirconium 95 & $1.7 \times 10^{4}$ & $7.8 \times 10^{4}$ & 65.2 \\
\hline 8 & Niobium 95 & $3.3 \times 10^{5}$ & $1.5 \times 10^{5}$ & 35.0 \\
\hline 9 & Ruthenium 103 & $4.3 \times 10^{4}$ & $2.0 \times 10^{4}$ & 39.5 \\
\hline 10 & Ruthenium 106 & $3.4 \times 10^{5}$ & $1.6 \times 10^{5}$ & 366 \\
\hline 11 & Tellurium $127 \mathrm{~m}$ & $4.2 \times 10^{3}$ & $1.9 \times 10^{3}$ & 109 \\
\hline 12 & Iodine 129 & $3.3 \times 10^{-2}$ & $1.5 \times 10^{-2}$ & $6.2 \times 10^{9}$ \\
\hline 13 & Cesium 134 & $1.7 \times 10^{5}$ & $7.8 \times 10^{4}$ & 750 \\
\hline 14 & Cesium 137 & $9.4 \times 10^{4}$ & $4.3 \times 10^{4}$ & 11,000 \\
\hline 15 & Cerium 141 & $2.4 \times 10^{4}$ & $1.1 \times 10^{4}$ & 32.3 \\
\hline 16 & Cerium 144 & $6.1 \times 10^{5}$ & $2.8 \times 10^{5}$ & 284 \\
\hline 17 & Promethiom 147 & $9.0 \times 10^{4}$ & $4.1 \times 10^{4}$ & 956 \\
\hline 18 & Plutonium 238 & $2.1 \times 10^{3}$ & $9.7 \times 10^{2}$ & 32,500 \\
\hline 19 & Plutonium 239 & $2.9 \times 10^{2}$ & $1.3 \times 10^{2}$ & $8.9 \times 10^{6}$ \\
\hline 20 & Plutonium 240 & $4.5 \times 10^{2}$ & $2.1 \times 10^{2}$ & $2.4 \times 10^{6}$ \\
\hline 21 & Plutonium 241 & $1.1 \times 10^{5}$ & $5.1 \times 10^{4}$ & 5,350 \\
\hline 22 & Americium 241 & $2.0 \times 10^{2}$ & $9.2 \times 10^{1}$ & $1.5 \times 10^{5}$ \\
\hline 23 & Curium 242 & $1.7 \times 10^{4}$ & $7.8 \times 10^{3}$ & 163 \\
\hline 24 & Curium 244 & $1.3 \times 10^{3}$ & $6.0 \times 10^{2}$ & 6,630 \\
\hline
\end{tabular}

(a) ${ }^{N} \mathrm{t}$ a Fission Product ${ }^{14} \mathrm{C}$ is formed by neutron activation of
impurity in fuel. 
TABLE H.2. Significant Fission Products in Spent PWR Fue 1 (4 years after discharge)

Isotope

${ }^{3} \mathrm{H}$

${ }_{85} \mathrm{C}$

${ }^{89} \mathrm{Sr}$

${ }^{90} \mathrm{Sr}$

$91_{Y}$

$95_{\mathrm{Zr}}$

${ }^{95} \mathrm{Nb}$

${ }^{103_{\mathrm{Ru}}}$

${ }^{106} \mathrm{Ru}$

$127 \mathrm{~m}_{\mathrm{Te}}$

129 I

${ }^{134} \mathrm{Cs}$

${ }^{137} \mathrm{Cs}$

${ }^{141} \mathrm{Ce}$

${ }^{144} \mathrm{Ce}$

${ }^{147} \mathrm{Pm}$

${ }^{238} \mathrm{Pu}$

$239 \mathrm{Pu}$

${ }^{240} \mathrm{Pu}$

$241 \mathrm{Pu}$

${ }^{241} \mathrm{Am}$

${ }^{242} \mathrm{Cm}$

${ }^{244} \mathrm{Cm}$
Radioactive

Inventory

(Ci per

assembly)

$1.6 \times 10^{2}$

$3.4 \times 10^{-1}$

$3.3 \times 10^{3}$

$2.8 \times 10^{4}$

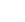

--

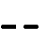

$-$

$6.4 \times 10^{3}$

$1.5 \times 10^{-2}$

$1.7 \times 10^{4}$

$3.9 \times 10^{4}$

$5.6 \times 10^{3}$

$1.2 \times 10^{3}$

$9.4 \times 10^{2}$

$1.3 \times 10^{2}$

$2.1 \times 10^{2}$

$4.1 \times 10^{4}$

$9.1 \times 10^{1}$

7.2

$5.0 \times 10^{2}$ 
APPENDIX I

PATHWAYS OF RADIATION

EXPOSURE TO MAN 


\section{APPENDIX I \\ PATHWAYS OF RADIATION EXPOSURE TO MAN}

To evaluate the risks involved in shipping spent fuel, the impact of radiological releases to man must be determined. Exposure pathways to man must be identified in order to evaluate the impact of releases. The pathways by which man can be exposed to radiation from a transportation accident are illustrated in Figure I.1. The exposure pathways can be grouped into those associated with gaseous effluents, liquid effluents and direct radiation from the transport system. Table I.l lists the various pathways of exposure to man. (1)

The fundamental equation for calculating radiation dose rate from the pathways listed in Table I.1 is:

$$
R_{i p r}=C_{i p} U_{p} D_{i p r}
$$

where

$$
\begin{aligned}
& R_{i p r} \text { is the dose rate to organ } r \text { from nuclide } i \text { via pathway } p \text {, } \\
& C_{i p} \text { is the concentration of nuclide } i \text { in the medium pathway } p \text {, } \\
& U_{p} \text { is the usage: the exposure or intake rate associated with } \\
& \text { pathway } p \text {, }
\end{aligned}
$$

and

$D_{i p r}$ is the dose rate factor: a number specific to a given nuclide $i$, pathway $p$, and organ $r$ which can be used to calculate radiation dose rate from exposure to a given radionuclide concentration or a radionuclide intake.

Equations tailored to each specific exposure pathway are derived from this equation. The principal difference between pathways is the manner in which the radionuclide concentrations are calculated. 


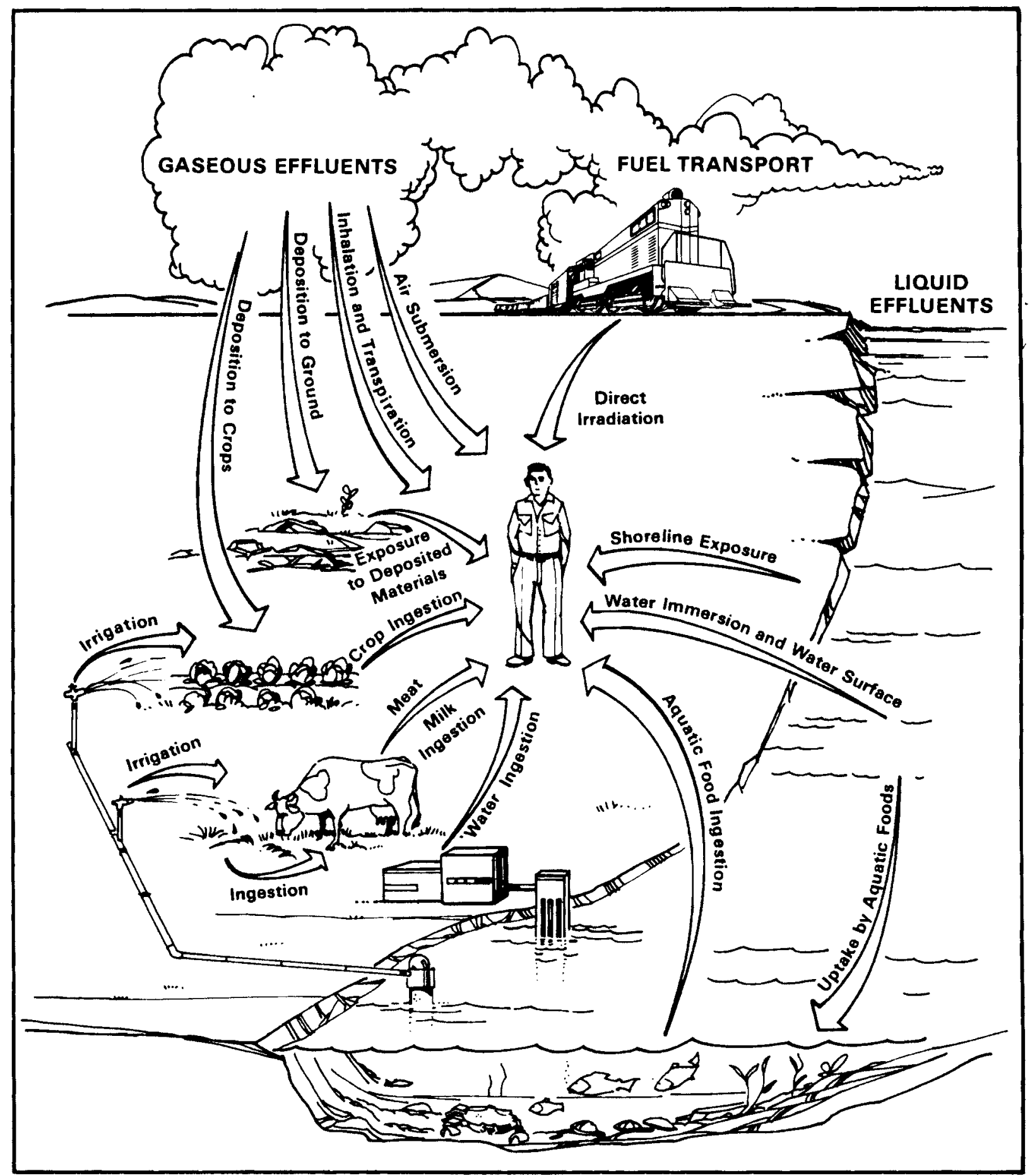

FIGURE I.1. Exposure Pathways to Man 
TABLE I.1. Pathways of Exposure to Man (1)

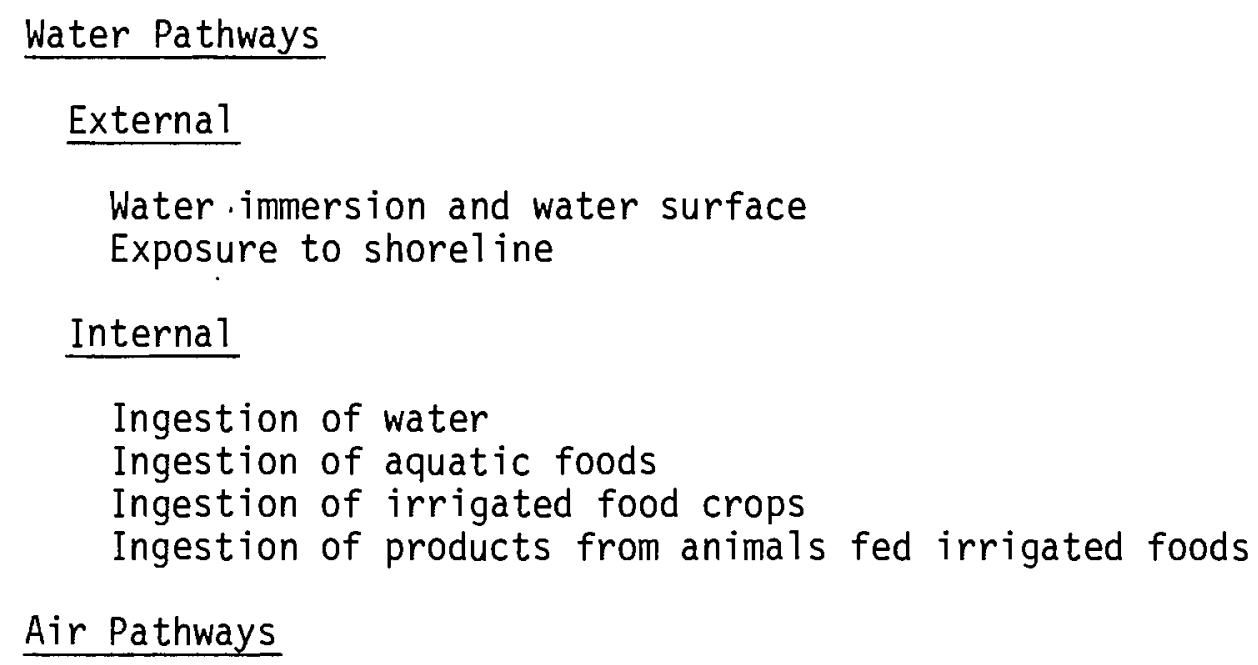

Exposure during transport of fuels

The liquid effluent pathway for transportation accidents is not considered to be a significant hazard to the population. The only releases that involve liquids in a transportation accident are those accidents where leakage of cavity coolant containing small amounts of activity occurs. This release does not constitute a significant hazard to the public.

Direct radiation is not assumed to be a hazard since the population is assumed to be evacuated for 100 meters from the accident point. At that distance, there is negligible direct radiation dose even with no neutron shield in place around the cask. 
For purposes of this study, only the air pathway was considered significant. It is assumed in transportation accident analysis that contaminated crops can be confiscated to reduce the threat from the deposition-ingestion pathway. Thus, it can be seen that the airborne inhalation dose dominates all the other exposure pathways for transportation accidents.

In WASH-1400, (2) approximate percentages of latent cancer fatalities attributable to each type of airborne exposure mode are shown in Table I.2, (2) both on a whole body and an organ-by-organ basis. It is evident from those results that lung cancer due to inhalation of radioactive material in the passing cloud is the dominant contribution to the total latent cancer fatalities. This illustrates that latent health effects due to an accident should be calculated on an organ-by-organ basis. The results given in Table I.2 show that the inhalation dose is the dominant pathway in determining the consequence of a release of fission products from reactor fuel.

TABLE I.2. Contributigh of Different Exposure Modes to Latent Cancer

\begin{tabular}{|c|c|c|c|c|c|c|c|c|}
\hline & Leukemia & $\underline{\text { Lung }}$ & Breast & Bone & $\begin{array}{l}\text { GI } \\
\text { Iract }\end{array}$ & $\begin{array}{c}\text { All } \\
\text { Other }\end{array}$ & Total & $\begin{array}{r}\text { Whole } \\
\text { Body }(a)\end{array}$ \\
\hline External Cloud & 0.2 & 0.5 & 0.5 & 0.1 & 0.1 & 0.3 & 1 & 3 \\
\hline Inhalation from Cloud & 0.5 & 59.0 & 10.0 & 0.2 & 1.0 & 0.2 & 71 & 15 \\
\hline External Ground (7 days) & 4.0 & 8.0 & 8.0 & 1.0 & 1.0 & 3.0 & 25 & 47 \\
\hline External Ground (7 days) & 2.0 & 2.0 & 6.0 & 1.0 & 1.0 & 2.0 & 13 & 30 \\
\hline Inhalation of Resuspended Contamination & 0.1 & 3.0 & 0.1 & 0.1 & 0.1 & 0 & 3 & 2 \\
\hline Ingestion of Contaminated Foods & 0.2 & 0.2 & 0.5 & 0.1 & 0.1 & 0.2 & 1 & 4 \\
\hline Total & 7 & 72.7 & 16 & 2.5 & 3 & 6 & 114 & 100 \\
\hline
\end{tabular}

(a) Whole body values are proportional to 50-year whole-body man-rem.

\section{REFERENCES}

1. D. L. Brenchley et al., Environmental Assessment Methodology for the Nuclear Fuel Cycle. BNWL-2219, Pacific Northwest Laboratory, Richland, Washington, June 1977.

2. Reactor Safety Study, An Assessment of the Accident Risks in U.S. Commercial Nuclear Power Plants. WASH-1400 (NUREG-75/014), U.S. Nuclear Regulatory Commission, Washington, DC, October 1975. 


\section{DISTRIBUTION}

No. of

Copies

G. C. Allen, Jr.

Sandia National Laboratories

Division 4553

A1buquerque, NM 87185

J. C. Allen

U.S. Department of Transportation

Materials Transportation Bureau

400 Seventh Street, S.W.

Washington, D.C. 20590

T. D. Anderson

Department of Energy

Routing NE-340

Washington, D.C. 20545

R. F. Barker

International Atomic Energy Agency

P. 0 . Box 100

A-1400 Vienna, Austria

R. M. Bernero

Office of Nuclear Research

U.S. Nuclear Research

Regulatory Commission

Washington, D.C. 20555

K. A. Carlson

DOE Albuquerque Operations Office

A1buquerque, NM 87115
A. A. Churm
Chicago Patent Group
DOE Chicago Operations Office
9800 South Cass Avenue
Argonne, IL 50439

27 DOE Technical Information
Center
No. of

Copies

F. P. Falci

Department of Energy

Routing NE-340

Washington, D.C. 20545

S. Goldsmith

Office of Nucear Waste Isolation

Battelle Project Management Division

505 King Avenue

Columbus, $\mathrm{OH} 43201$

0. P. Gormley

Department of Energy

Routing NE-340

Washington, D.C. 20545

R. J. Hall

Office of NWTS Intergration

Battel le Project Management

Diversion

Battelle

505 King Avenue

Columbus, $\mathrm{OH} 43201$

B. Hol loman

Office of Technology

Assessment

U.S. Congress

Washington, D.C. 20510

R. M. Jefferson

Sandia National Laboratories

Dept. 4550

Attn: TTC Master File (1)

A1buquerque, NM 87185

\section{K. Klinstiver}

Accident Analysis Branch

Materials Transportation Bureau U.S. Department of Transportation 2100 Second Street, N.W.

Washington, D.C. 20590 
No. of

Copies

R. W. Lambert

General Electric

175 Curtner Avenue

San Jose, CA 95125

R. Laufer

NUCLEONICS WEEK

1221 Avenue of the Americas

New York, NY 10020

M. J. Lawrence

Department of Energy

Routing NE-340

Washington, D.C. 20545

R. Y. Lowrey

DOE Albuquerque Operations Office

P. 0. Box 5400

A1buquerque, NM 87115

R. E. Luna

Sandia National Laboratories

Diversion 4551

Albuquerque, NM 87185

J. D. McClure

Sandia National Laboratories

Division 4551

A1buquerque, NM 87185

C. E. MacDonald

U.S. Nuclear Regulatory Commission

Transportation Certification Branch

Washington, D.C. 20555

S. Meyers

Department of Energy

Routing NE-340

Washington, D.C. 20545
No. of

Copies

Major General J. Murray

Association of American

Railroads

1929 L Street, N.W.

Washington, D.C. 20036

R. W. Peterson

Office of NWTS Integration

Battelle Project Management

Division

Battelle

505 King Avenue

Columbus, $\mathrm{OH} 43201$

R. B. Pope

Sandia National Laboratories

Division 4552

Albuquerque, NM 87185

R. R. Rawl

Office of Hazardous Materials Regulations

Department of Transportation

400 Seventh Street, S.W.

Washington, D.C. 20590

J. L. Russell

Office of Radiation Programs

Environmental Protection Agency

Aw-459

401 M. Street, S.W.

Washington, D.C. 20460

E. W. Shepherd

Sandia National Laboratories

Division 4551

Albuquerque, NM 87185

J. A. Sisler

Department of Energy

Routing NE-340

Washington, D.C. 20545 
No. of

Copies

M. J. Steindler

Argonne National Laboratory

9800 South Cass Avenue

Argonne, IL 60439

(3) TTC Library

Sandia National Laboratories

Department 4551

Albuquerque, NM 87185

R. F. Williams

Electrical Power Research Inst.

P. 0. Box 10412

Palo Alto, CA 94304

Nuclear Safety Research

Association

P. 0. Box 1307

Falls Church, VA 22041

ONSITE

DOE-Richland Operations Office

E. A. Bracken

R. B. Goranson

H. E. Ransom

J. J. Schreiber

M. W. Shupe

Pacific Northwest Laboratory

H. K. Elder (5)

J. R. Friley

C. W. Stewart

Technical Information Ma (5)

Publishing Coordination (2)

Battelle-Human Affairs Research

Center

A. H. Schilling 
J 